\title{
Geomorphic origin of a lithalsa in the Great Slave Lowlands, Northwest Territories, Canada
}

\author{
by
}

Adrian J.R. Gaanderse

A thesis submitted to the Faculty of Graduate and Postdoctoral Affairs in partial fulfillment of the requirements for the degree of

Master of Science

in

Geography

Carleton University

Ottawa, Ontario

(C) 2015, Adrian J.R. Gaanderse 


\begin{abstract}
Lithalsas, mineral-based permafrost mounds with segregated ice in their cores, are found in the Great Slave Lowlands, Northwest Territories. They are formed in glaciolacustrine deposits of Glacial Lake McConnell and ancestral Great Slave Lake left as water levels receded during the Holocene to the present level of Great Slave Lake. Ground ice conditions were examined in one 700-m long lithalsa adjacent to Highway 3, $30 \mathrm{~km}$ west of Yellowknife. Samples obtained to depths of $8.4 \mathrm{~m}$ from 17 boreholes revealed domed layers of silts, sands, and clays in the lithalsa, with related layers appearing horizontally beneath an adjacent peatland. Segregated ice lenses over $0.1 \mathrm{~m}$ thick occurred in clays below $4 \mathrm{~m}$ depth. $\delta^{18} \mathrm{O}$ values of lithalsa ice indicate modern water sources for the ground ice. The ages of organic material recovered from the lithalsa imply permafrost aggradation initiated growth of the feature within the last 700 to 400 years.
\end{abstract}




\section{Acknowledgements}

I would firstly like to thank Steve Wolfe for his infectious enthusiasm for scientific research, as well as his continuous encouragement and confidence in me. It was deeply appreciated both in the field and throughout the writing process in Ottawa. Fieldwork would also not have been the same without our annual pike fishing excursions. Thanks Steve.

Chris Burn's constant support and attention to detail at Carleton University for the past four years is greatly valued. I've become a better writer, presenter and critical thinker because of his efforts. Thanks Chris.

I'd like to also thank Steve Kokelj and Peter Morse for their contributions during lab analysis and writing. My field assistants Mark Ednie, Brendan O’Neill and Chris Stevens went the extra mile for me in Yellowknife. Thank you guys for all of your efforts.

My long-standing friends from Ottawa, as well as new ones I had the pleasure of meeting at school along the way, were always ready to listen to my ups and downs throughout this degree, and I thank them for all of their support. Rachel Plewes assisted with some statistical portions of this thesis, and I thank her for her help.

Finally, my parents and family have always been behind me no matter what I do in life, and this degree has been no different. Thank you for everything you've done to get me to where I am now. 


\section{Table of Contents}

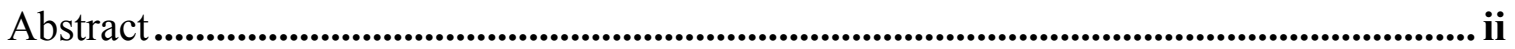

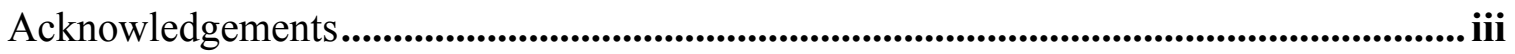

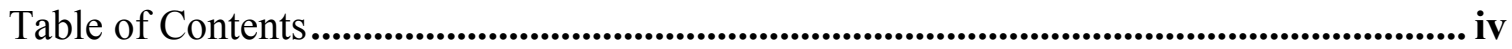

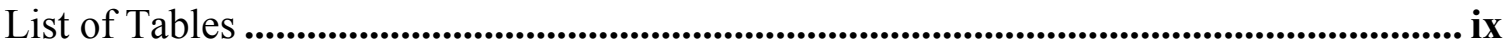

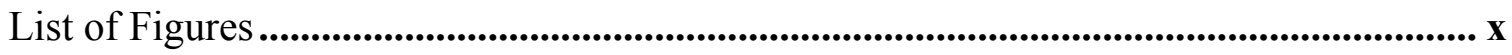

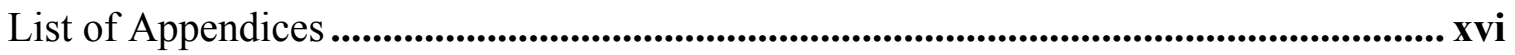

Chapter 1 Overview and objectives ..................................................................................... 1

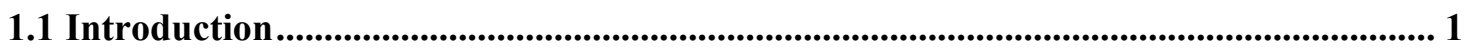

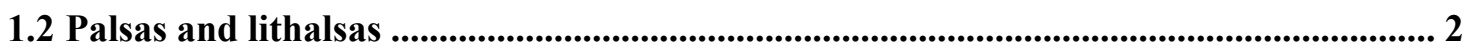

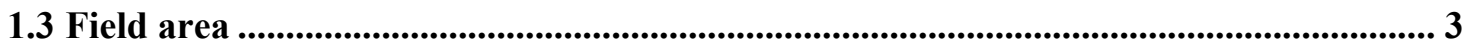

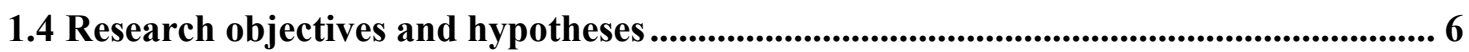

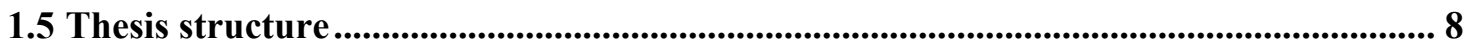

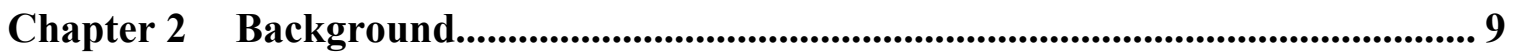

2.1 Water migration and ice segregation ................................................................................. 9

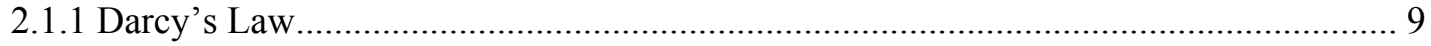

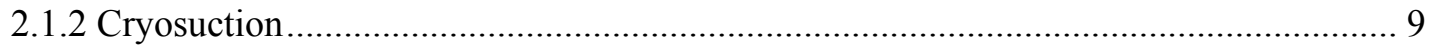

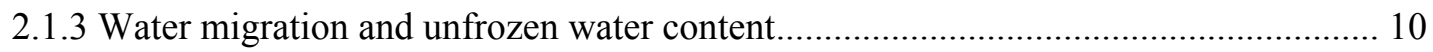

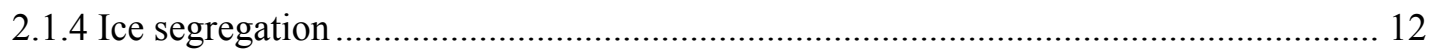

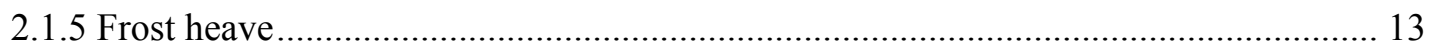

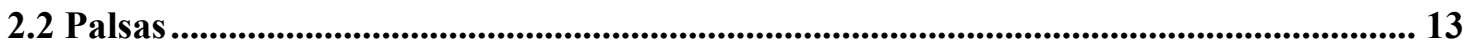

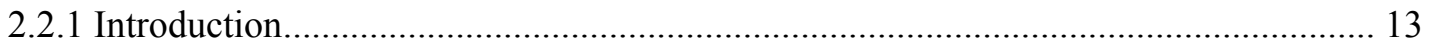

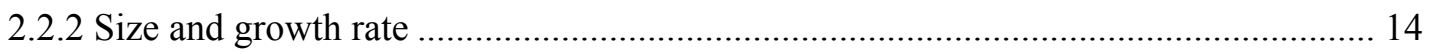

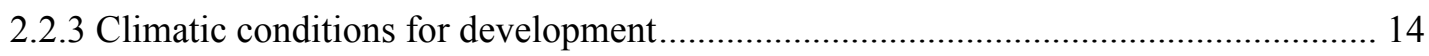




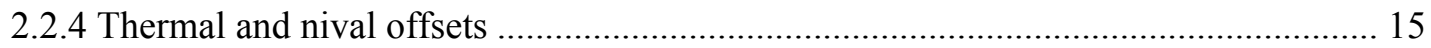

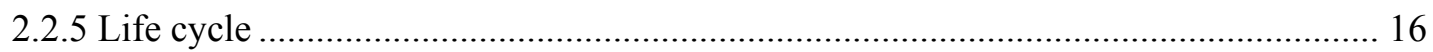

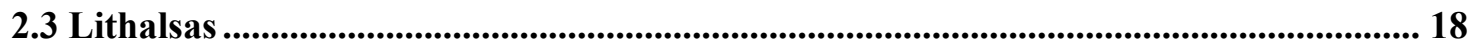

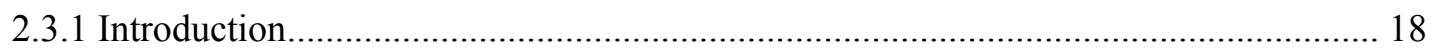

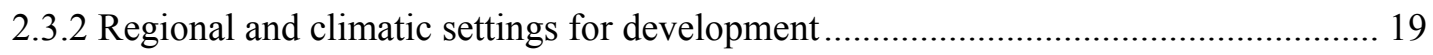

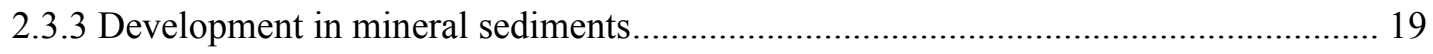

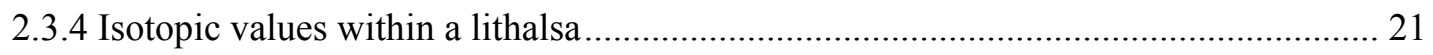

2.3.5 The potential development of a lithalsa from a palsa ............................................ 21

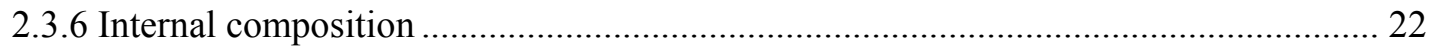

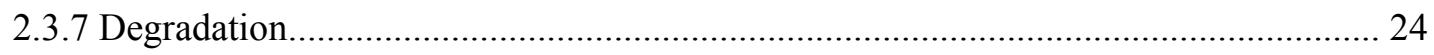

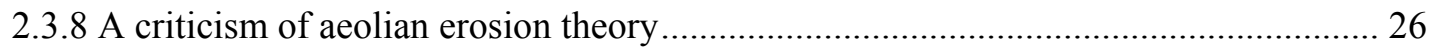

2.4 Palsas, lithalsas, and climate change ............................................................................ 27

2.5 Palsa and lithalsa age ............................................................................................................. 28

2.6 Potential for lithalsas near Yellowknife ......................................................................... 29

2.7 Stable isotopes as an indicator of ice lens water sources .......................................... 30

Chapter 3 Study region and methods ........................................................................ 33

3.1 Study area

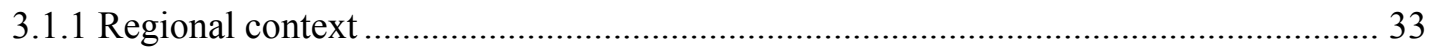

3.1.2 Glacial Lake McConnell and Great Slave Lake ...................................................... 33

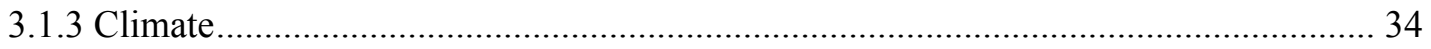

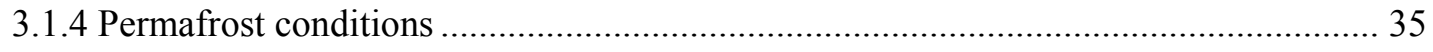

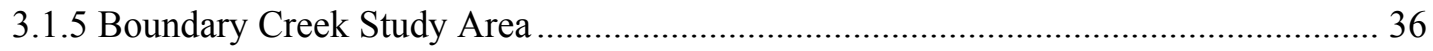

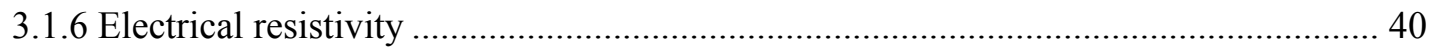

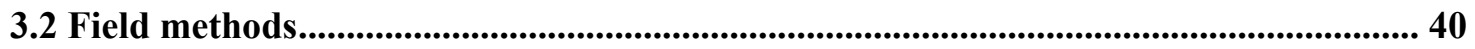

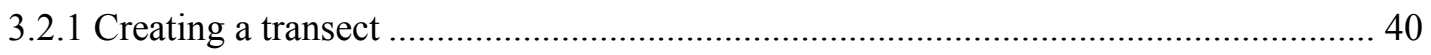




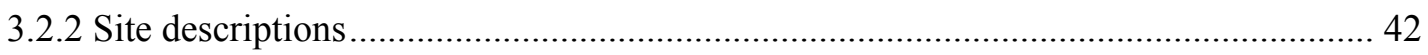

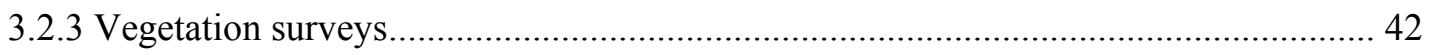

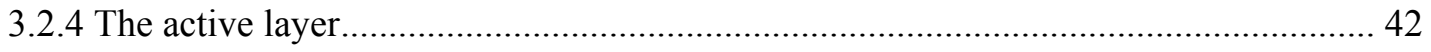

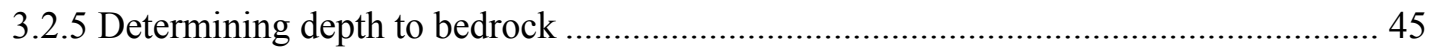

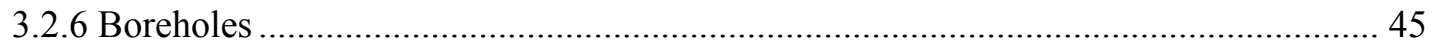

3.3 Laboratory methods .................................................................................................................... 49

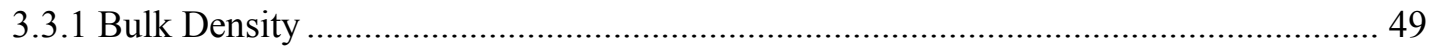

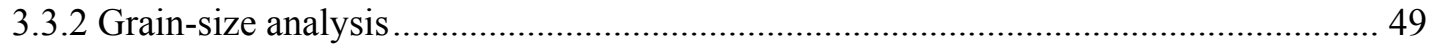

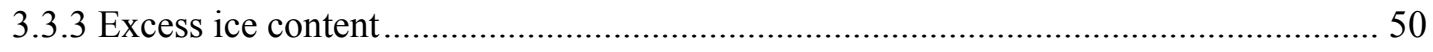

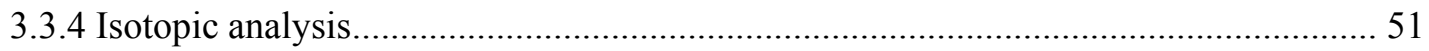

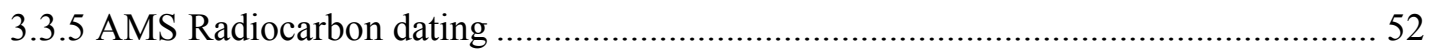

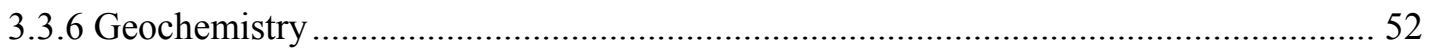

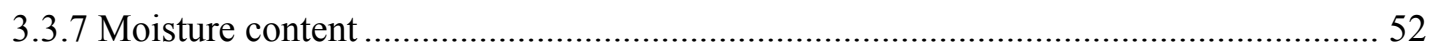

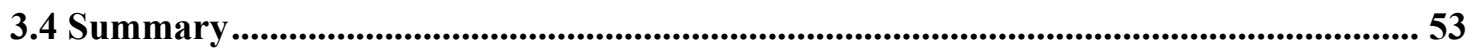

Chapter 4 Results ............................................................................................................. 54

4.1 Local Site Conditions ............................................................................................................. 54

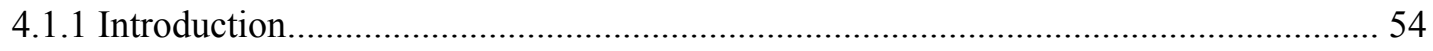

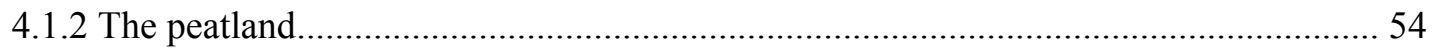

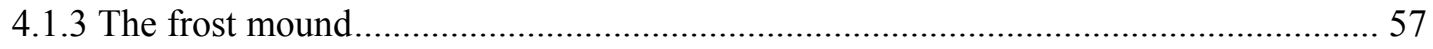

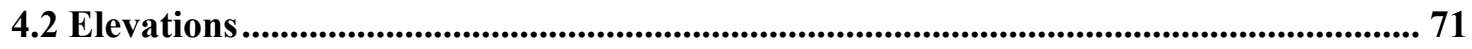

4.3 Water jet drilling to bedrock ......................................................................................................... 71

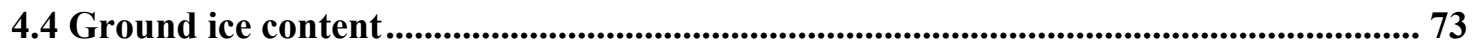

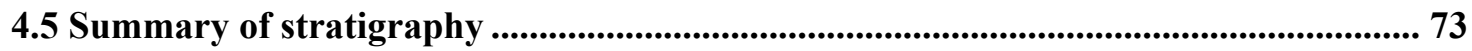

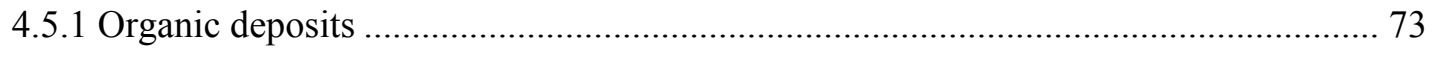

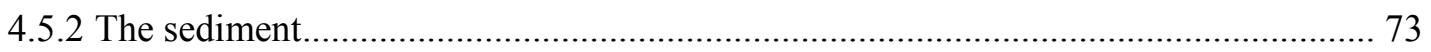




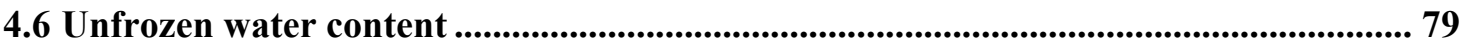

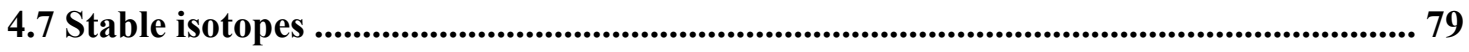

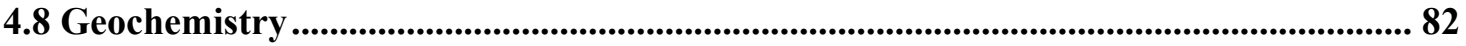

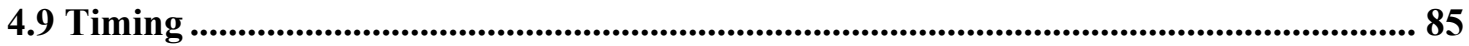

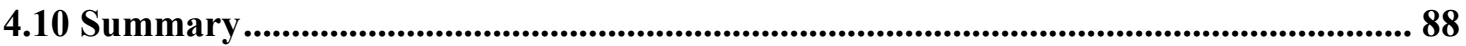

Chapter 5 Discussion.......................................................................................................... 90

5.1 Stratigraphic interpretation and temporal scale................................................. 90

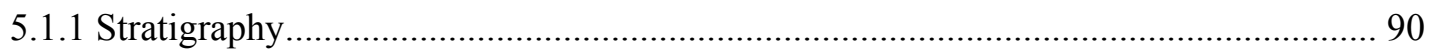

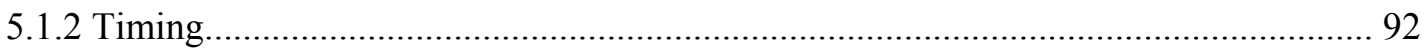

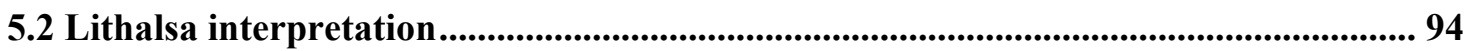

5.3 Ground cracking and continued growth .......................................................................... 96

5.4 Ground ice and cryostructures .................................................................................................. 97

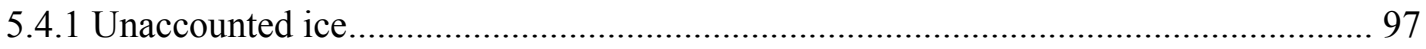

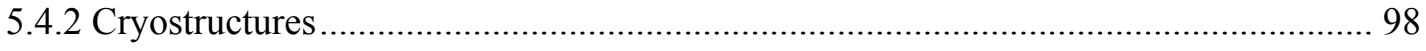

5.5 Isotopic analysis.............................................................................................................. 101

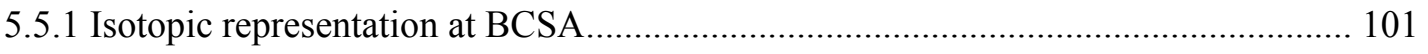

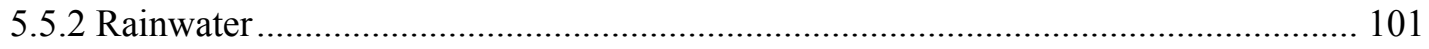

5.5.3 Local water bodies and comparable $\delta^{18} \mathrm{O}$ values in the literature............................. 104

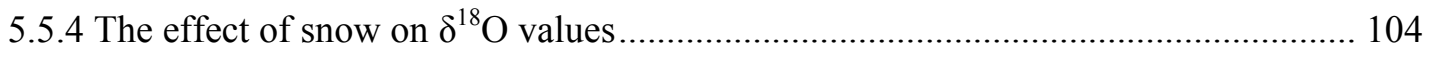

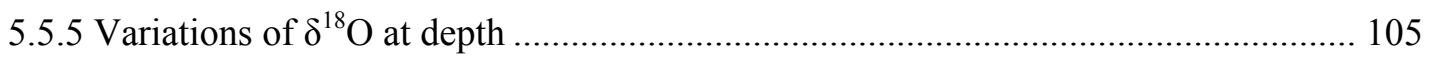

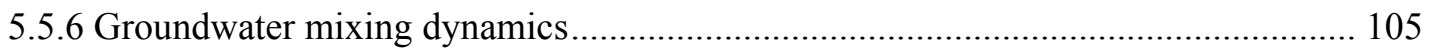

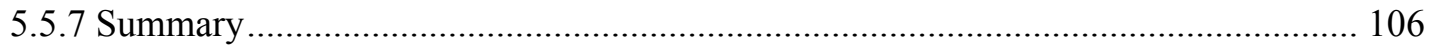

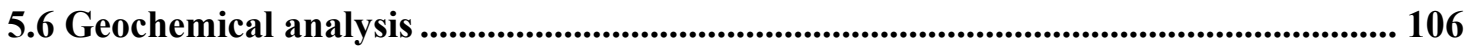

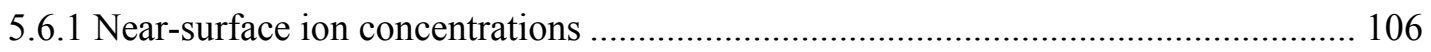

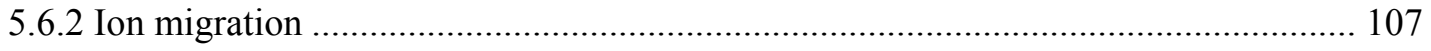




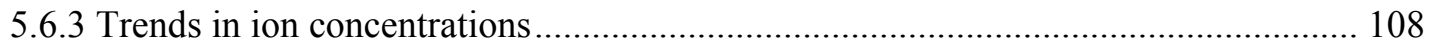

5.7 Electrical resistivity corroboration....................................................................................... 110

5.8 Conceptual model of landscape evolution ........................................................................... 110

5.9 Broader implications........................................................................................................... 114

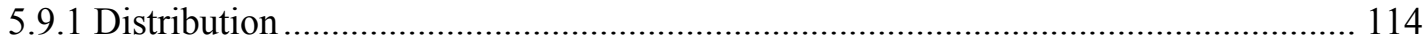

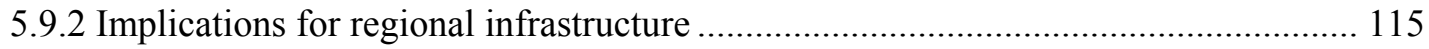

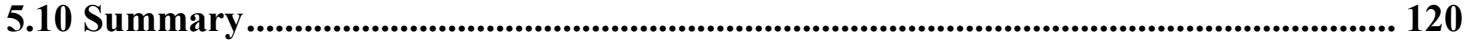

Chapter 6 Conclusions ........................................................................................... 122

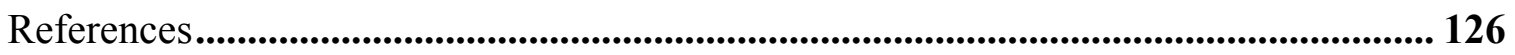

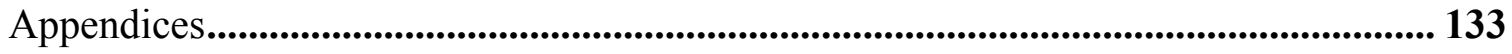




\section{List of Tables}

Table 3.1: Cryostructure classifications from Murton and French (1994). ..................... 48

Table 4.1: An overview of surficial conditions at BCSA............................................ 55

Table 4.2: Ice thickness per $0.5 \mathrm{~m}$ depth increment and cumulative ice lens thickness with depth in boreholes a) BH01; b) BH02; c) BH03; d) BH04; and e) BH05............... 59

Table 4.3: Spearman correlation coefficients $\left(r_{s}\right)$ for geochemistry samples from BH04

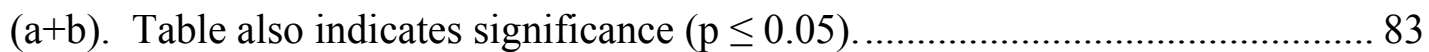

Table 5.1: Radiocarbon samples used in the temporal interpretation of BCSA and their implied significance. 


\section{List of Figures}

Figure 1.1: Permafrost map of Canada and reported lithalsa observations across the country (map adapted from Natural Resources Canada, lithalsa distribution from

Wolfe et al. 2014).

Figure 1.2: Study area overlain with Glacial Lake McConnell extent at approximately 10 ka BP, and the adjacent Laurentide Ice Sheet. Study site (BCSA) highlighted with a star. Adapted from Smith (1994) and Wolfe (1998)..... 5

Figure 1.3: Distribution of lithalsas within the Great Slave Uplands (GSU) and Great Slave Lowlands (GSL) based on aerial photograph interpretation. A total of 1,777 lithalsas are identified within the limit of mapping (Stevens et al. 2012a). Note NWT Highway 3 extending from Behchoko to Yellowknife. Map modified from Stevens et al. (2012a).

Figure 2.1 Sample unfrozen water content characteristic curves for a range of soil types (Burt and Williams 1976, Figure 1).

Figure 2.2: A general model of the formation of the frozen core (1) of a palsa in a peatland (2) with a silty substratum (3). a) the beginning of the thaw season; b) the end of the first thaw season; c) embryo palsa; d) young palsa; e) mature palsa; f) old collapsing palsa surrounded by a large water body; g) fully thawed palsa creating a circular pond (5) on the peatland and the thawed peat is decomposed (4); h) new peat formation (6) starts in the pond (Seppälä 1982, 1986, 2006)

Figure 2.3: Aerial view of a lithalsa field in northern Quebec (Pissart 2002, Figure 1). Many lithalsas are degrading. Examples of lithalsa stages are: A fully formed lithalsa (A). Degrading lithalsas with circular ring ramparts as well as ponds forming 
on its tops (B). Ponds from fully degraded lithalsas (C) with surrounding ramparts (D) 20

Figure 2.4: Graphic model of key steps in the evolution of the BGR lithalsa, from initial non-permafrost terrain (a) to the actual situation (f), and the probable future decay of the lithalsa and the formation of a thermokarst pond ( $g$ and $h$ ). The question marks in (d) refer to the unknown permafrost extension in the bedrock in the past and during the 1950s. Location (c) is a georeferenced point used for topographical measurements since July 2000 (Calmels et al. 2008, Figure 12).

Figure 2.5: Distribution of ice in a lithalsa plateau in northern Quebec described by Pissart (2002, Figure 2) modified from Allard et al. (1996). 1) Active layer; 2) icerich layer (50-80\% in volume), aggradational ice; 3 ) low ice content (10-30\% in volume), reticulate ice; 4) thick and regularly spaced lenses of segregation ice (50$80 \%$ in volume). Note an ice layer thicker than $0.20 \mathrm{~m}$ near the permafrost base. The figure illustrates vegetation densification (A) and melted aggradational ice (B).

Figure 2.6: Potential ramparts on the landscape near BCSA. The mature spruce trees may be used for scale. 31

Figure 3.1: Aerial photograph looking northward over BCSA. 38

Figure 3.2: A composite of temperatures representing the maximum, minimum, and mean ground thermal conditions for one year (September 1, 2012 - August 31, 2013) at the BCSA feature. Data provided by P. Morse, Geological Survey of Canada....... 39

Figure 3.3: Electrical resistivity model and interpretation for a) Line 1 depicting icebonded permafrost and ice-rich zones, as well as areas of thawing at depth along the 
borehole transect and boreholes BH01-05; and b) Line 2 depicting the highway embankment, pond, unfrozen sediment near the pond and ice-rich clay as well as beneath the forest, and the ice-rich core itself (Oldenborger 2012, Figures 8a and 10a).

Figure 3.4: Cross-section along the transect of BCSA. LiDAR measurements are from 0 to $115 \mathrm{~m}$ on the $\mathrm{x}$-axis. The highway embankment was estimated ( 0 to $-30 \mathrm{~m}$ on the $\mathrm{x}$-axis). Note: BH05 is approximately $150 \mathrm{~m}$ west of the transect. Approximate borehole depths are indicated at each drill site.

Figure 3.5: Tilted transmission line pole on the north (highway) side of the feature at BCSA. View is east toward Yellowknife.

Figure 3.6: A frozen sample with visible ice as retrieved in the field. 47

Figure 4.1: View of drill site BH01 facing north........................................................ 56

Figure 4.2: Stratigraphy, frozen bulk density ( $\rho)$, cryostructures, visible ice, and $\delta^{18} \mathrm{O}$ values at $\mathrm{BH} 01$ (peatland). 58

Figure 4.3: View of drill sites a) BH02 facing south along the transect toward the peatland; b) BH03 facing north on the transect; c) $\mathrm{BH} 04 \mathrm{~b}$ facing north on the transect; and d) $\mathrm{BH} 05$ off the transect facing east.

Figure 4.4: Stratigraphy, frozen bulk density $(\rho)$, cryostructures, visible ice, and $\delta^{18} \mathrm{O}$ values at $\mathrm{BH} 02$ (edge of feature; approximately $1 \mathrm{~m}$ above peatland)

Figure 4.5: Stratigraphy, frozen bulk density $(\rho)$, cryostructures, visible ice, and $\delta^{18} \mathrm{O}$ values at $\mathrm{BH} 03$ (side of feature, near the peak; approximately $3 \mathrm{~m}$ above the peatland). 
Figure 4.6: Stratigraphy, frozen bulk density $(\rho)$, cryostructures, visible ice, and $\delta^{18} \mathrm{O}$ values at BH04 $(\mathrm{a}+\mathrm{b})$ (top of feature; approximately $4 \mathrm{~m}$ above the surface of the peatland).

Figure 4.7: Core samples recovered from BH04b at a) 7.41-7.58 m, demonstrating thick layers of sediment and ice; and b) 8.24-8.40 m, demonstrating pure ice at depth.... 68

Figure 4.8: Stratigraphy, frozen bulk density $(\rho)$, cryostructures, visible ice, and $\delta^{18} \mathrm{O}$ values at BH05 (side of feature on highway side; approximately the same elevation as $\mathrm{BH} 03)$.

Figure 4.9: Stratigraphy, cryostructures and visible ice from a) BH12 and b) BH13. Bulk densities were not calculated. Note: the scale of this diagram is larger than previous borehole diagrams. 72

Figure 4.10: Borehole elevation (with organic cover removed), and distance from $\mathrm{BH} 01$, with thickness of visible ice in each borehole. The reference height is the top of mineral sediment at $\mathrm{BH} 01$.

Figure 4.11: Ternary diagrams derived from Shepard (1954) displaying a) all grain size samples recovered from boreholes BH01-05 at the BCSA site; and b) all samples classified as clayey silt, and categorized into upper clayey silts, and lower clayey silts. The lower clayey silts occurred below the silty sand stratigraphic layer at BCSA.

Figure 4.12: A cross-sectional profile of BCSA along the transect, displaying the all boreholes with 4 stratigraphic units, ground ice thicknesses, and implied connections between layers at depth. Ice lenses in boreholes are depicted in white. 
Figure 4.13 Co-isotope plot for samples collected at BCSA, Boundary Creek, and Yellowknife River. BCSA borehole samples $=3.80 \mathrm{x}-84.61$

Figure 5.1: Stable isotope plot of $\delta^{2} \mathrm{H}$ and $\delta^{18} \mathrm{O}$ values for all borehole and water sampling results at BCSA and the surrounding region, alongside isotopic values of Wisconsinan ice (Michel 2011), historical Yellowknife rainfall and snowfall records, and records from Baker Creek and Pocket Lake (Gibson and Reid 2010). Local Meteoric Water Line $=6.91 \mathrm{x}-19.53$ 102

Figure 5.2: $\delta^{18} \mathrm{O}$ values of BH01-05 with depth at BCSA, plotted with $\delta^{18} \mathrm{O}$ values of local samples. Also indicated are the ranges in $\delta^{18} \mathrm{O}$ values for historical Yellowknife rainfall and Baker Creek snowfall records (Gibson and Reid 2010), as well as the range of Wisconsinan glacial ice (Michel 2011).

Figure 5.3 Profile of $\mathrm{BH} 05$ with $\mathrm{Ca}^{2+}, \mathrm{Cl}^{-}$and $\mathrm{Na}^{+}$indicated. Sediment stratigraphy is also shown.

Figure 5.4: Conceptual diagram of the landscape throughout the Holocene at BCSA including a) deep water clay deposition; b) shallow water clayey silt deposition; c) near-shore silty sand deposition over peatland; d) silty sand deposition over lithalsa and terrestrial emergence of peatland; e) lacustrine deposition over lithalsa and permafrost aggradation at peatland; f) continued permafrost aggradation and terrestrial emergence of lithalsa; g) permafrost aggradation and ice segregation under lithalsa; and h) present day conditions. Note: date overlaps occur due to the uncertainty of the exact date for terrestrial emergence at the lithalsa site. 
Figure 5.5: Historical air photos of the BCSA study site at a) 1945; b) 1961; c) 1994; and d) 2010; with the BCSA lithalsa outlined. The section of lithalsa eventually cut through by new Highway 3 is circled. 116

Figure 5.6: $150 \mathrm{~m}$ section along Highway 3 at BCSA, illustrating a $0.95 \mathrm{~m}$ subsidence of the highway right-of-way where the roadway was built through the lithalsa (adapted from Stevens et al. 2012b).

Figure 5.7 Thaw subsidence with a deepening active layer at BH04 $(\mathrm{a}+\mathrm{b})$. 119

Figure 5.8: Thaw strain for BH04 $(\mathrm{a}+\mathrm{b})$ using a frozen bulk density of $2.10 \mathrm{~g} \mathrm{~cm}^{-3}$ 121 


\section{List of Appendices}

Appendix A: Table of wet gravimetric moisture contents with depth from all deep boreholes at BCSA.

Appendix B: Table of frozen bulk densities $(\rho)$ with depth from all deep boreholes at

BCSA

Appendix C: Results of $\delta^{18} \mathrm{O}$ determinations from ice in boreholes BH01-05 at BCSA.

Appendix D: Results of $\delta^{2} \mathrm{H}$ determinations from ice in boreholes BH01-05 at BCSA. 138

Appendix E: Plot of $\delta^{18} \mathrm{O}$ values for all boreholes with depth at BCSA.

Appendix F: Results of stable isotope sampling of local water sources from summer

2012.

Appendix G: Geochemistry results of $\mathrm{Ca}^{2+}, \mathrm{Cl}^{-}$and $\mathrm{Mg}^{2+}$ with depth at all BCSA

boreholes.

Appendix H: Geochemistry results of $\mathrm{K}^{+}, \mathrm{Na}^{+}$and $\mathrm{SO}_{4}{ }^{-2}$ with depth at all BCSA

boreholes.

Appendix I.1: Plot of all ions with depth at BH01.

Appendix I.2: Plot of all ions with depth at BH02.

Appendix I.3: Plot of all ions with depth at BH03.

Appendix I.4: Plot of all ions with depth at BH04.

Appendix I.5: Plot of all ions with depth at BH05. 
Appendix J: Plots of ion concentrations in samples recovered from $\mathrm{BH} 04$ indicating the strengths of relations between $\mathrm{Ca}^{2+}, \mathrm{Cl}^{-}, \mathrm{Mg}^{+}, \mathrm{K}^{+}, \mathrm{Na}^{+}$and $\mathrm{SO}_{4}{ }^{2-} \ldots \ldots \ldots \ldots \ldots \ldots \ldots . . . . . . . . .154$ 


\section{Chapter 1 Overview and objectives}

\subsection{Introduction}

This thesis examines the origin and practical significance of a large ice-cored perennial frost mound in the Great Slave Lowlands west of Yellowknife, Northwest Territories. Similar mounds, known as lithalsas, have been reported from the discontinuous permafrost zone, and are abundant in the western and eastern Canadian subarctic (Harris 1993; Delisle et al. 2003; Pissart 2003, 2010; Calmels and Allard 2008; Calmels et al. 2008; Pissart et al. 2011). They have also been observed in southern Siberia and northern India in mountain environments (Iwahana et al. 2012; Wünnemann et al. 2008).

These permafrost mounds are ice-rich, and may be used as indicators of present and past permafrost environments (Wolfe et al. 2014). Thaw subsidence of such terrain may have major impacts on infrastructure, such as buildings, roads, and airfields, raising maintenance costs and reducing the operational life of the facilities (Fortier and Bolduc 2008). A geomorphic understanding of these features should assist land management and terrain predictability in regions where they are found.

Geotechnical reports have noted the presence of deep-seated ground ice, i.e., at depths greater than $4 \mathrm{~m}$, and other ice-rich terrain in the Yellowknife region (Aspler 1978; Hoeve et al. 2004). However, few data on the stratigraphy, composition, and formation of ice-rich mounds in this region have been published (Wolfe et al. 2014). Consequently, these mounds have not been recognized as potentially ice-rich geomorphic landforms. 


\subsection{Palsas and lithalsas}

Pissart (2002) defined palsas as perennial frost mounds covered by peat, situated in the discontinuous permafrost zone. Their cores generally consist of frozen peat or peat with fine-grained mineral soil, small ice crystals, thin ice layers, and segregated ice. Palsas have been recorded in Fennoscandia, Iceland, Alaska, Siberia, and Canada (Seppälä 1986).

Palsas vary in morphology from round or oval-shaped domes to elongated ridges, and complex, "amoeba-like" hummocks to large peat plateaus (Seppälä 1979, 1982). Complex palsas may have many basins, hollows, and ponds of thermokarst origin (Seppälä 2006). Palsas resembling dome-shaped oval mounds can rise up to $10 \mathrm{~m}$ above the surrounding land, and reach up to $100 \mathrm{~m}$ in length. Most are considerably smaller than this, rarely reaching over $7 \mathrm{~m}$ in height (Pissart 2010). Longitudinal, elongatedridge palsas may be up to $0.5 \mathrm{~km}$ long and $6 \mathrm{~m}$ in height (Seppälä 2006). Plateau palsas, 1-1.5 $\mathrm{m}$ in height, have been found in Fennoscandia to cover an area of $1 \mathrm{~km}^{2}$ (Seppälä 2006).

Lithalsas are permafrost mounds in the same size range as palsas (Calmels et al. 2008). Seppälä (1988) rejected the term mineral palsa to describe palsa-like formations with no peat cover, and suggested that those using the term lacked understanding of Finnish Lapland in which the term palsa originated. Subsequently, the term lithalsa was proposed by Harris (1993) to describe permafrost mounds formed by ice segregation that are found in mineral soils in the discontinuous permafrost zone. Pissart (2002) explained that the term lithalsa sounds like the term palsa and their morphological resemblance implies a common origin. Lithalsas lack a peat cover, yet still contain an ice-rich core. 
Lithalsas form as permafrost aggrades into unconsolidated sediments in an environment where there is sufficient water and frost-susceptible soil to enable ice segregation from the surface into the ground. They are relatively rare features that require a specific set of thermal, sedimentological, and hydrological site conditions in order to form, including fine-grained sediments, a low ground thermal regime, and an abundant water supply (Calmels et al. 2008; Wolfe et al. 2014). Thus far, they have been found in discontinuous permafrost (Figure 1.1). In Yukon, lithalsas have been reported in the sporadic discontinuous zone whereas lithalsas in the Hudson Bay region of Quebec have been observed over a broader area, appearing in both the sporadic and extensive discontinuous permafrost zones, northwards to the southern limit of continuous permafrost (Harris 1993; Delisle et al. 2003; Pissart 2003, 2010; Calmels and Allard 2008; Calmels et al. 2008; Pissart et al. 2011).

\subsection{Field area}

The study site for this thesis is situated near the north shore of Great Slave Lake, within the Great Slave Lowlands, in the extensive discontinuous permafrost zone (Figure 1.2). The site is approximately $30 \mathrm{~km}$ west of Yellowknife, NWT, and is referred to as the Boundary Creek Study Area (BCSA). The region was deglaciated at about $11 \mathrm{cal} \mathrm{ka}$ BP (Dyke et al. 2003), after which fine-grained lacustrine sediments were deposited in the topographic lows between rolling Precambrian bedrock outcrops.

Mixed woodlands containing white birch are characteristic of the area, though the region's poor drainage allows black spruce to thrive (Wolfe et al. 2014). Small lakes, fens, and peatlands are common throughout the region (Wolfe et al. 2014). Annual mean 


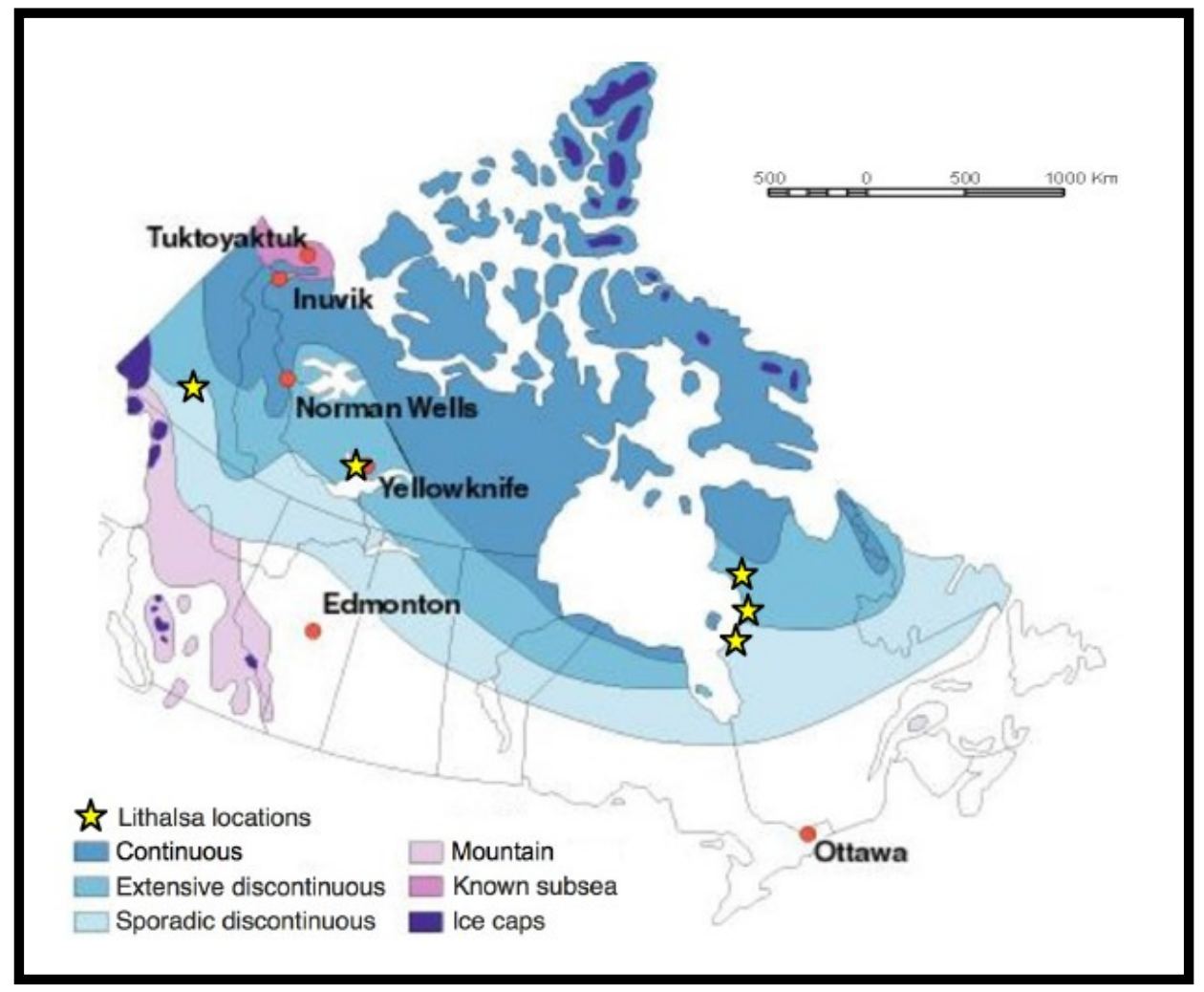

Figure 1.1: Permafrost map of Canada and reported lithalsa observations across the country (map adapted from Natural Resources Canada, lithalsa distribution from Wolfe et al. 2014). 


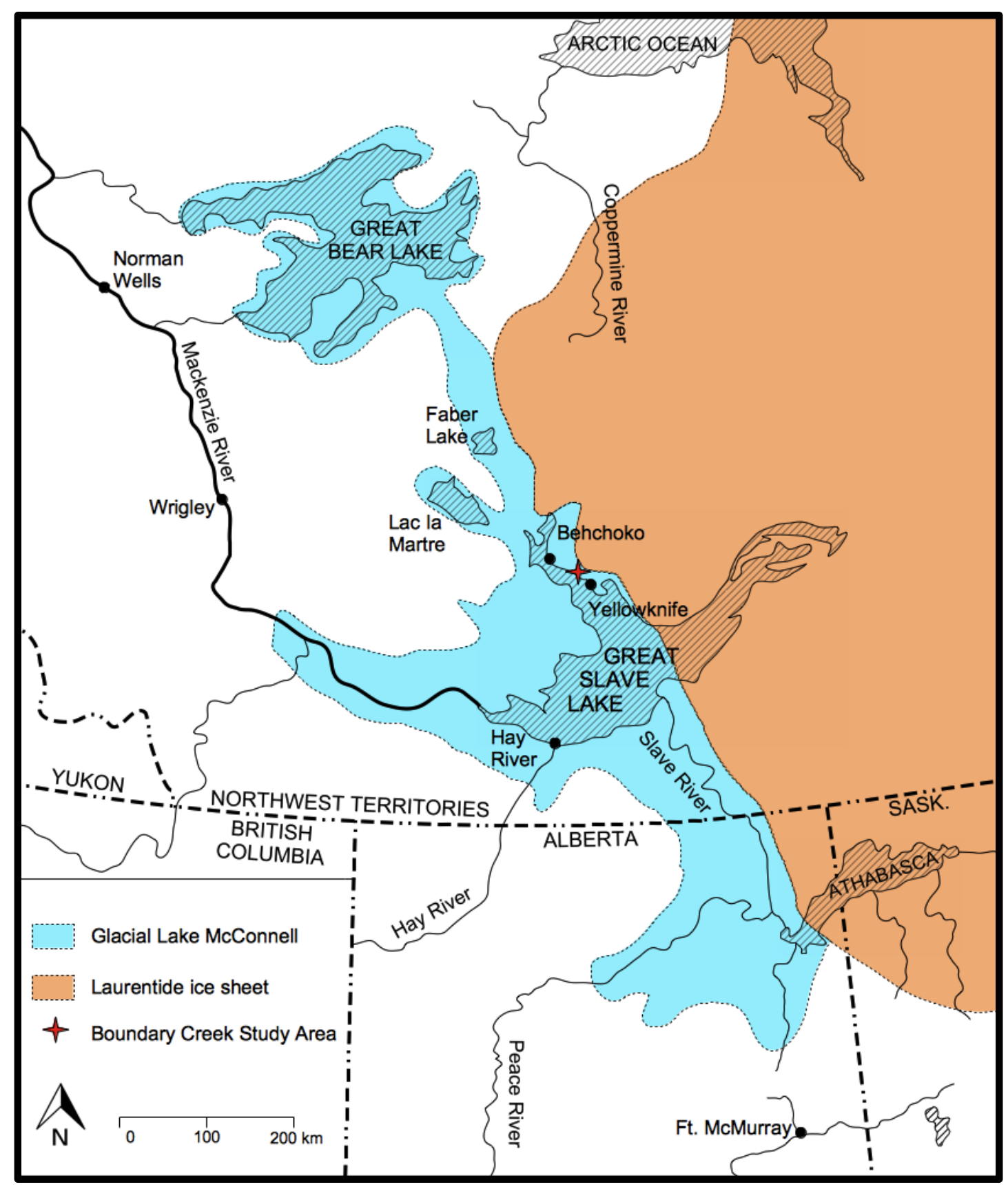

Figure 1.2: Study area overlain with Glacial Lake McConnell extent at approximately 10 $k a B P$, and the adjacent Laurentide Ice Sheet. Study site (BCSA) highlighted with a star. Adapted from Smith (1994) and Wolfe (1998). 
air temperature at Yellowknife is $-4.6^{\circ} \mathrm{C}$ and $42 \%$ of the annual precipitation falls as snow (Environment Canada 2012).

Boundary Creek Study Area $\left(62^{\circ} 32^{\prime} \mathrm{N} ; 114^{\circ} 58^{\prime} \mathrm{W}\right)$ is located on the south side of NWT Highway 3, at 166 m a.s.l. Boundary Creek flows towards Great Slave Lake, which is at $156 \mathrm{~m}$ a.s.1. The lithalsa examined in this thesis is approximately $4 \mathrm{~m}$ higher than the surrounding topography, and is over $700 \mathrm{~m}$ in length; it appears as a prominent feature in the landscape. The study site is situated in an area representative of the local terrain encompassing a bedrock outcrop, a pond, peatland, and a mixed forest. The study site's close proximity to the highway creates easy access, facilitating logistics for investigations, and making possible an examination of the potential effects of ice-rich bodies near infrastructure. Although this thesis examines only one potential permafrost mound, more than 1700 similar features have been identified within the Great Slave Lowlands (Figure 1.3) (Wolfe et al., 2014), indicating a much larger extent of ice-rich terrain in this region than previously recognized.

\subsection{Research objectives and hypotheses}

The purpose of this study is to determine the composition and origin of the feature at BCSA in order to provide a better understanding of the geomorphic processes occurring in the region and how these processes may affect human activity. In order to accomplish these goals, the specific research objectives are to:

1) Determine the stratigraphic composition of the feature and surrounding landscape using terrain surveys and borehole drilling to depths of over $8 \mathrm{~m}$; and 


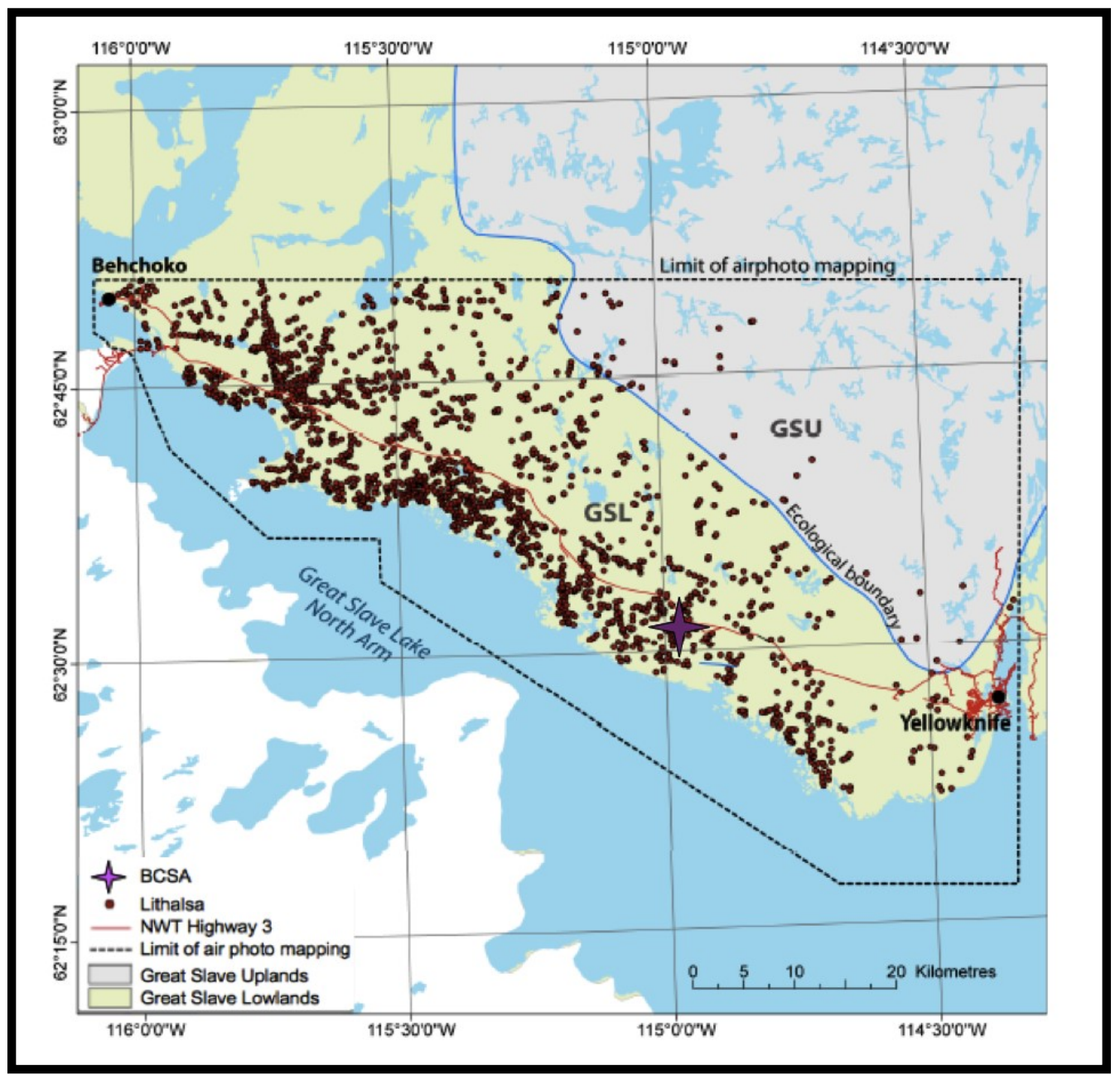

Figure 1.3: Distribution of lithalsas within the Great Slave Uplands (GSU) and Great Slave Lowlands (GSL) based on aerial photograph interpretation. A total of 1,777 lithalsas are identified within the limit of mapping (Stevens et al. 2012a). Note NWT Highway 3 extending from Behchoko to Yellowknife. Map modified from Stevens et al. (2012a). 
2) Determine the feature's origin using radiocarbon dating, sediment geochemistry, and stable isotopes of sediment, organic matter, and ice samples collected from boreholes, and to link these results to past landscape conditions in the region.

The working hypotheses of the research are:

1) The frost mound under study is a lithalsa, containing a deep-seated core of segregated ice accounting for the feature's raised topography;

2) The lithalsa formed after deglaciation of the Great Slave Lowlands and its ice-rich core formed from post-glacial water sources.

\subsection{Thesis structure}

This thesis is composed of 6 chapters. The following chapter outlines formation and degradation of palsas and related lithalsas. Ice segregation and factors affecting ground heave are also discussed. Chapter 3 describes the study area, including a brief history of Glacial Lake McConnell, and outlines the field and laboratory methods used in the study. Chapter 4 presents terrain conditions at the drill sites, as well as borehole cryostratigraphy of the feature and nearby terrain. Isotopic, geochemical and radiocarbon results are linked with the cryostratigraphy. Chapter 5 discusses the lines of evidence accounting for the feature's geomorphic origin and growth, and outlines the broader implications of this feature by extrapolating the results to encompass the distribution observed on the landscape. Chapter 6 summarizes the results of the thesis, presents conclusions, and suggests opportunities for further research. 


\section{Chapter 2 Background}

This chapter contains two components. The first is an overview of the mechanisms for water migration through frozen ground, as well as a description of ice segregation processes. The second component is a discussion of palsas and lithalsas, detailing their development, age, and relation to regional surficial geology in the Yellowknife region.

\subsection{Water migration and ice segregation}

\subsubsection{Darcy's Law}

Unfrozen water movement through a frozen soil, or more generally, the flow of fluid through a porous medium, is described by Darcy's Law:

$$
Q=A K \frac{\Delta h}{L}
$$

where $\mathrm{Q}$ is the volumetric flow rate, $\mathrm{A}$ is the cross-sectional area perpendicular to the flow, $K$ is the hydraulic conductivity, $\Delta h$ is the hydraulic head, and $\mathrm{L}$ is the flow path length. The pressure gradient is represented by the fraction $\Delta h / L$. Darcy's Law applies to slow, viscous flow such as by groundwater. Without a pressure gradient, no water movement occurs, whereas under a pressure gradient, water migrates from points of high pressure to low pressure.

\subsubsection{Cryosuction}

In freezing soils, liquid water is confined to progressively smaller pores as freezing and ice formation takes place. The water remaining in the liquid phase has a low free energy in order to maintain thermodynamic equilibrium with the ice phase (Williams and Smith 1989). This may be represented as a lower pore-water pressure. The lower 
pressures that result from water changing from liquid to ice drive water migration through freezing soil. The temperature gradient of the soil acts as the driving gradient as water migrates to lower pressures, i.e., colder areas within the substrate.

\subsubsection{Water migration and unfrozen water content}

The unfrozen water content of sediment has an important influence on the ability of groundwater to migrate through a substrate. A sediment's temperature versus unfrozen water content characteristic at temperatures near $0^{\circ} \mathrm{C}$ depends largely on its pore size. Pore size has an influence on $K$ due to the dependence of unfrozen water content on pore size distribution, void ratio, particle size and specific surface area (Burt and Williams 1976). $K$ decreases as temperatures decline past $0^{\circ} \mathrm{C}$ due to a decrease in unfrozen water content (Burt and Williams 1976).

A sediment's specific surface area (SSA) determines how much adsorbed water is being held by the mineral particles, and therefore how much unfrozen water remains at temperatures below $0^{\circ} \mathrm{C}$ (Figure 2.1). Sands have a low SSA and most of the pore water freezes close to $0^{\circ} \mathrm{C}$ (Williams and Smith 1989), resulting in a very low $K$ (Burt and Williams 1976). Silts have a larger SSA, therefore more unfrozen adsorbed water remains, resulting in higher $K$. Silts have small enough pores to remain largely ice-free just below $0^{\circ} \mathrm{C}$ (to $-0.2^{\circ} \mathrm{C}$ ) but even at lower temperatures, the capillaries allow flow (Burt and Williams 1976). Clays have the largest SSA of all mineral particles, and contain the most unfrozen water at temperatures below $0^{\circ} \mathrm{C}$, but due to their small pores, clays have lower $K$ than silts below $0^{\circ} \mathrm{C}$. Clays, however, contain higher volumes of unfrozen water at lower temperatures (below $-0.8^{\circ} \mathrm{C}$ ), allowing water to move through the substrate (Burt and Williams 1976). 


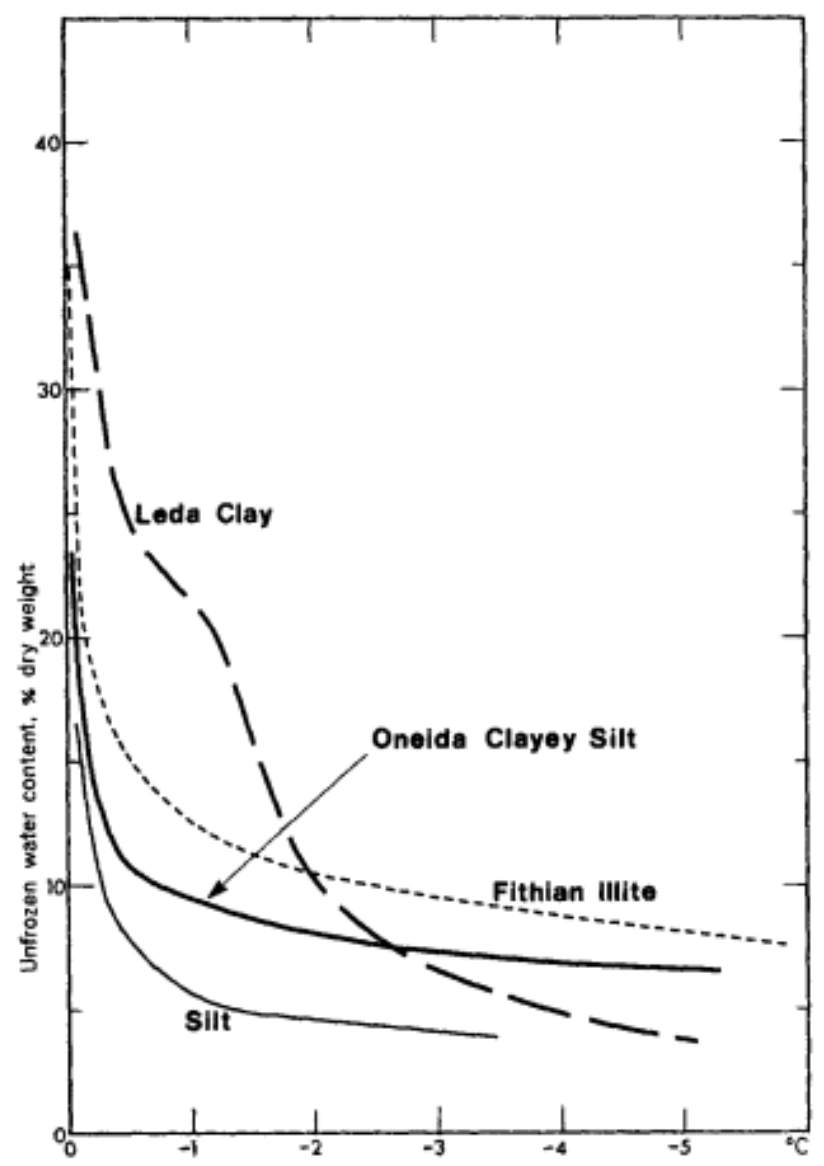

Figure 2.1 Sample unfrozen water content characteristic curves for a range of soil types (Burt and Williams 1976, Figure 1). 


\subsubsection{Ice segregation}

Segregated ice develops due to moisture transfer caused by thermally induced pressure gradients in the ground (Konrad and Morgenstern 1980). Unfrozen water migrates in the direction of decreasing temperature, forming lenses of ice in soils below $0^{\circ} \mathrm{C}$. Ice lens formation is dependent on several factors including time, water supply, frost penetration rate, direction of freezing, and the grain size of soils.

When soil freezes, most of the water transport between the $0^{\circ} \mathrm{C}$ isotherm and the first lens is in the liquid phase and can be divided into two parts (Burn 1986). First, between the $0^{\circ} \mathrm{C}$ isotherm and pore ice, i.e. the warmest temperature at which ice can grow where water is still liquid, and second, in the 'cold' part between the pore ice and the 'warm' side the aggrading ice lens (Konrad and Morgenstern 1980, Burn 1986). This part is referred to as the frozen fringe (Miller 1972). In the frozen fringe, liquid is transported in unfrozen pore water or adsorbed water surrounding soil particles. The ice lens expels particles is it grows (Burn 1986). The first lens ice to form in silty sediments generally forms between -0.05 and $-0.3^{\circ} \mathrm{C}$ (Konrad and Morgenstern 1980). Experimental data from Konrad and Morgenstern (1980) have shown that water flow is continuous through the frozen fringe during ice lens formation and water does not accumulate within it.

Two types of ice segregation occur: primary and secondary ice segregation. Primary segregation occurs when no cooling of the soil or advancement of the frost line takes place. Secondary segregation differs from primary segregation as it occurs with an advancing frost front. The thickness of ice lenses depends on the rate at which the freezing front advances. When the $0^{\circ} \mathrm{C}$ isotherm advances, the frozen fringe thickens and 
the lens forms at progressively lower temperatures, causing a lower $K$ and slowed lens growth (O’Neill 2011). If the frost front advances slowly, the ice lens may grow thicker, whereas rapid cooling forms thin lenses (Williams and Smith 1989) and new lens growth moves closer to the $0^{\circ} \mathrm{C}$ isotherm's location. As long as a thermal gradient and a source of groundwater exist, ice segregation may continue to grow lenses.

\subsubsection{Frost heave}

The $9 \%$ expansion that occurs when soil water freezes is not generally regarded as frost heave (Williams and Smith 1989). Frost heave occurs from the development of ice lenses in excess of the volumetric expansion of water as it freezes. When a volume of water is drawn into frozen soil to raise the ice content above soil saturation, excess ice is formed (Burn 1986).

The pressure exerted by the soil as it expands with the accumulation of ice is the frost heave pressure. For a soil to heave, it must overcome the resistance to expansion represented by the strength of the frozen soil in which it is contained. It is possible to stop frost heave with sufficient pressure even in fine-grained soils, but this pressure is on the order of MPa (Williams and Smith 1989), and it is therefore impractical to implement. The frost heave is responsible for many perennial mounds in the permafrost zone (Williams and Smith 1989).

\subsection{Palsas}

\subsubsection{Introduction}

Seppälä (1972) described the palsas of Finnish Lapland as perennial frost mounds rising above the surface of peat bogs with cores composed of peat and ice lenses. More recently, Pissart (2002) referred to palsas as perennial mounds covered by peat, found in 
the discontinuous permafrost zone, and raised chiefly by ice segregation. Seppälä (2006) agreed that palsas may contain a peat or mineral core, but that Lapland palsa cores are composed of only peat and ice.

\subsubsection{Size and growth rate}

Palsas appear as: 1) domes up to $100 \mathrm{~m}$ in length and usually not more than $7 \mathrm{~m}$ high (Pissart 2002); 2) complex elongated ridges up to $500 \mathrm{~m}$ long and $6 \mathrm{~m}$ high (Seppälä 2006); or 3) large circular plateaus 1 to $1.5 \mathrm{~m}$ high and over $1 \mathrm{~km}^{2}$ in area (Seppälä 1979 , 1982, 2006). These palsas, though different in shape, all contain frozen cores responsible for their raised topography. Thermal modeling by An and Allard (1995) demonstrated that palsas may conceivably grow up to $5 \mathrm{~m}$ high in a few decades after inception, and reach their maximum height in 200 years.

\subsubsection{Climatic conditions for development}

Temperatures characteristic of the discontinuous permafrost zone as well as low precipitation and a non-existent or thin snow cover are critical factors for palsa formation (Seppälä 1986, 2006). Although the lower mean annual air temperature (MAAT) limit of discontinuous permafrost in Canada is between -6 and $-8^{\circ} \mathrm{C}$ (Smith and Riseborough 2002), palsas exist in warmer environments where the upper limit in MAAT for palsa existence is reported to be 1 to $-1^{\circ} \mathrm{C}$ ( $\AA$ hman 1977, Dionne 1984, Seppälä 1986). Pissart (2002) suggested that palsas cannot form on the landscape if MAAT $\geq 0^{\circ} \mathrm{C}$. MAATs of $2^{\circ} \mathrm{C}$ to $-3^{\circ} \mathrm{C}$ are common in Lapland areas containing palsas (Seppälä 1986). 


\subsubsection{Thermal and nival offsets}

The ability of permafrost to exist at specific locations in a peatland otherwise devoid of permafrost is a function of the thermal offset $(\Delta T)$ :

$$
\Delta T=\frac{n t * I t(r k-1)}{P}
$$

where $I t$ is the thawing index for air temperature (degree days), and $P$ is the annual period (365 days), $n t$ is the scaling factor between summer air and ground temperatures (i.e., the plant vegetation effect), and $r k$ is equal to $\lambda t / \lambda f$ (where $\lambda t$ is thawed thermal conductivity ( $\lambda$ ) and $\lambda f$ is frozen $\lambda$ ) (Smith and Riseborough 2002). $\Delta \mathrm{T}$ is the difference between the annual mean ground surface temperature (AMGST) and the annual mean temperature at the top of permafrost (TTOP) (Burn 2004). $\Delta \mathrm{T}$ allows permafrost to exist in areas where the AMGST $>0^{\circ} \mathrm{C}$, and at its limit, where annual mean temperatures in the active layer are also $>0^{\circ} \mathrm{C}$ (Burn 2004). The thermal offset is due to the higher $\lambda$ of moist soil when frozen than when thawed, and may be enhanced by the moderating influence of snow cover on winter ground temperatures (Burn and Smith 1988). The drying of soil in summer further increases the seasonal change in $\lambda$, and both downward movement of water in the active layer in summer and upward movement in winter reinforce the asymmetry of seasonal ground temperature profiles (Burn and Smith 1988).

Peat has a larger seasonal variation in its thermal properties than mineral sediment. In summer, the peat surface is dry due to evaporation, resulting in a low $\lambda$ and inhibited ground warming. In the fall, peat becomes moister due to a reduced evaporation rate. When it freezes, $\lambda$ becomes greater and the ground may cool rapidly. This results in temperatures under peat that are much lower than areas that lack a peat cover (Williams and Smith 1989), and permafrost may be sustained. 
Snow cover is a factor in the difference between the MAAT and the mean annual ground surface temperature (MAGST) and can be represented by the nival offset:

$$
\text { Nival Off set }=\frac{I f(1-n f)}{P}
$$

where If is the freezing index for air temperature (freezing degree days), and $n f$ is a scaling factor between winter air and ground temperatures (i.e. the snow cover effect) (Smith and Riseborough 2002). The low $\lambda$ of snow restricts heat loss from the ground. On an annual basis, the effect of winter snow cover is generally greater than that of vegetation cover in summer, and consequently the MAGST is likely to be higher than the MAAT. A thick snow cover insulates ground surface temperatures from low winter air temperatures, whereas lower amounts of snowfall promote more effective heat withdrawal, lowering a soil's MAGST (Fries and Bergström 1910).

\subsubsection{Life cycle}

The life cycle of a peatland palsa, from inception to degradation, is summarized by Seppälä’s work in Finland (Seppälä 1982, 1986, 2006). Palsa formation begins with thin or absent snow cover at a peatland enabling frost penetration and the growth of ground ice (Figure 2.2a). The peat surface is raised by frost heave (Figure 2.2b), leading further to locally thinner snow. Heaving continues over several winters (Figure 2.2c). Freezing in the palsa core reaches the underlying sediment and the mature stage begins. Dilation cracks form on the top of the ridge as heaving splits the surface (Figure $2.2 \mathrm{~d}, \mathrm{e}$ ). As cracking separates the surface peat, degradation begins due to microclimatic conditions such as modifications to vegetation and snow cover, cracks allowing incoming 
a)

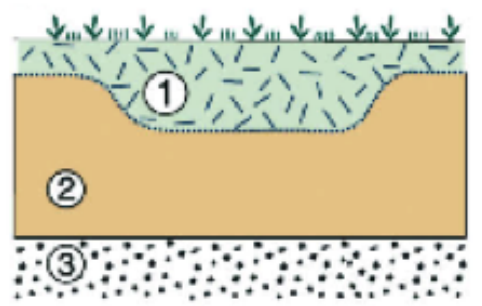

c)

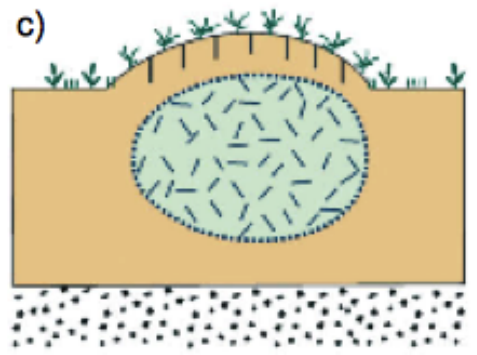

e)

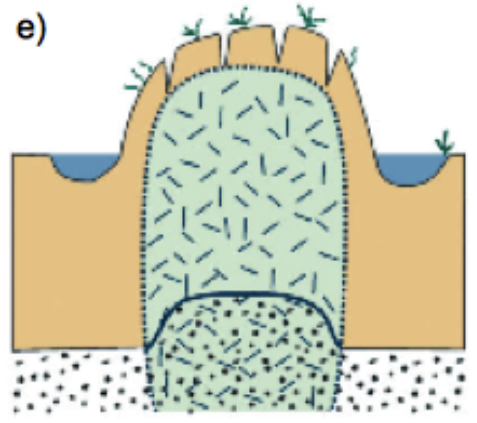

g)

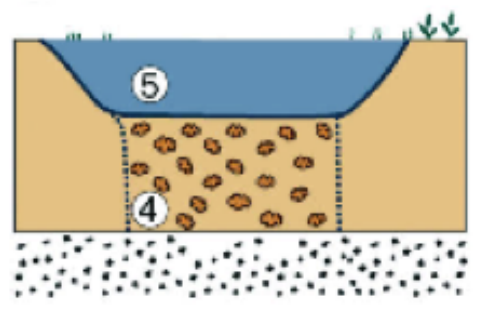

b)
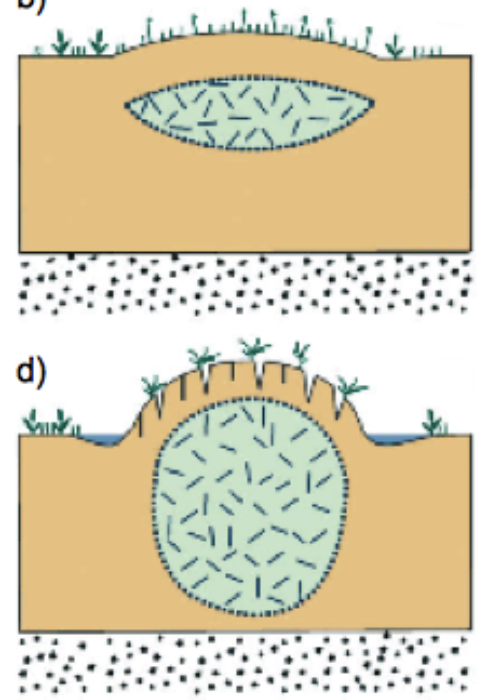

f)

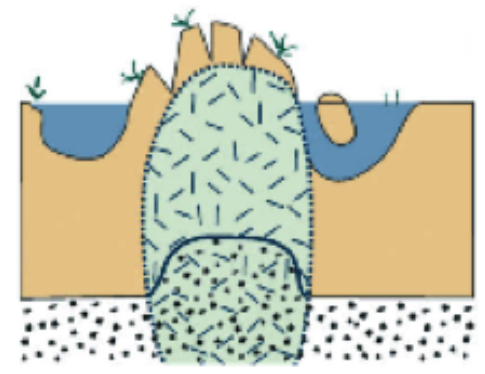

h)

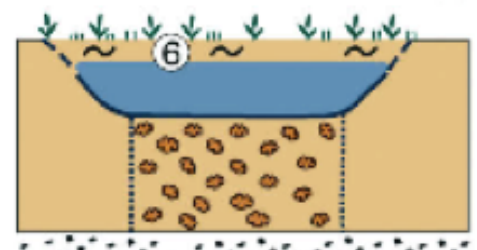

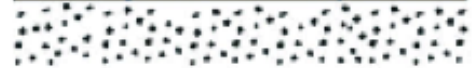

\begin{tabular}{|c|c|}
\hline 分 & Frozen core \\
\hline & Peat \\
\hline & Silt \\
\hline & Decomposed peat \\
\hline$\approx$ & New peat \\
\hline & Pond \\
\hline
\end{tabular}

Figure 2.2: A general model of the formation of the frozen core (1) of a palsa in a peatland (2) with a silty substratum (3). a) the beginning of the thaw season; b) the end of the first thaw season; c) embryo palsa; d) young palsa; e) mature palsa; f) old collapsing palsa surrounded by a large water body; g) fully thawed palsa creating a circular pond (5) on the peatland and the thawed peat is decomposed (4); h) new peat formation (6) starts in the pond (Seppälä 1982, 1986, 2006). 
solar radiation, or by percolating groundwater (Williams and Smith 1989). Peat blocks around the edges of the palsa collapse along dilation cracks into aggrading ponds surrounding the mound from the melting core. Removal of vegetation exposes the surface to rain erosion (Figure 2.2f). Thermokarst partially destroys the old palsa, and the landform becomes scarred with pits and collapse forms (Figure $2.2 \mathrm{~g}$ ). A renewed phase of peat formation may then take place (Figure $2.2 \mathrm{~h}$ ).

\subsection{Lithalsas}

\subsubsection{Introduction}

There is an ongoing debate, spanning decades, regarding the classification of perennial permafrost mounds, in particular around the terms 'mineral palsa' and 'lithalsa' (Washburn 1983; Harris 1993; Pissart 2002).

The term 'minerogenic palsa' was used by Åhman, (1976) and 'palse minérale', or 'mineral palsa', by Dionne (1978) to describe mineral-based palsa-like mounds with no peat. Seppälä (1988) rejected 'mineral palsa' because the palsas in Lapland may have formed under different environmental conditions than other frost mounds. Harris (1993) then coined the term 'lithalsa' to describe the palsa-like mounds with mineral substrates with little to no organic overburden and no peat cover. Matthews et al. (1997) suggested keeping the term 'palsa' for mounds that have had, at the beginning stages of growth, a thin peat cover, even if the cover no longer exists, and suggested retaining a genetic continuum between the two features, making differentiation between the formations difficult. With this in mind, Pissart (2002) remarked that the similar-sounding terms 'lithalsa' and 'palsa' suggests morphological resemblance and implies a common origin. This thesis adopts Pissart's (2002) view that Harris's (1993) definition of lithalsa should 
be used to describe mounds that are palsa-like without peat. Also for this thesis, mineral palsas and lithalsas are considered to be synonymous, a view shared by Westin and Zuidhoff (2001).

\subsubsection{Regional and climatic settings for development}

In Canada, lithalsas are found close to water bodies including modern stream valleys and shorelines, as well as adjacent to ponds or within lake basins (Wolfe et al. 2014). Circular palsas may appear on more uniform and flat surfaces such as lake basins, valleys, or marine lowlands where a uniform water supply exists, whereas lithalsas with linear and crescentic forms occur near ponds and streams, indicative of an asymmetrical water supply (Wolfe et al. 2014). Circular lithalsas have been reported from the Hudson Bay region of northern Quebec (Figure 2.3) with MAATs of $-4.6^{\circ} \mathrm{C}$ to $-7^{\circ} \mathrm{C}$ and MAGSTs of $-0.5^{\circ} \mathrm{C}$ to $-0.8^{\circ} \mathrm{C}$ (Vallée and Payette 2007; Calmels et al. 2008; Fortier and Aubé-Maurice 2008). Circular lithalsas have also been reported from Yukon with MAATs of $-2^{\circ} \mathrm{C}$ and MAGST's of $-0.2^{\circ} \mathrm{C}$ to $-0.5^{\circ} \mathrm{C}$ (Harris 1993). Outside Canada, Wünnemann et al. (2008) observed circular lithalsas in the Indian Himalayas with MAATs from $-4^{\circ} \mathrm{C}$ to $-6^{\circ} \mathrm{C}$, and Iwahana et al. (2012) reported linear lithalsas from the Akkol Valley in southern Siberia near Kazakhstan and Mongolia with a MAAT of $-4^{\circ} \mathrm{C}$.

\subsubsection{Development in mineral sediments}

Iwahana et al. (2012) studied one of many lithalsas developed in fine-grained sediment, located in the Akkol Valley on a terrace between mountains and Akkol Lake consisting of moraines and small ponds. Small vegetation and shrubs covered the area, but there was no peat. The lithalsa under study was $6 \mathrm{~m}$ high, $50 \mathrm{~m}$ long, and located 


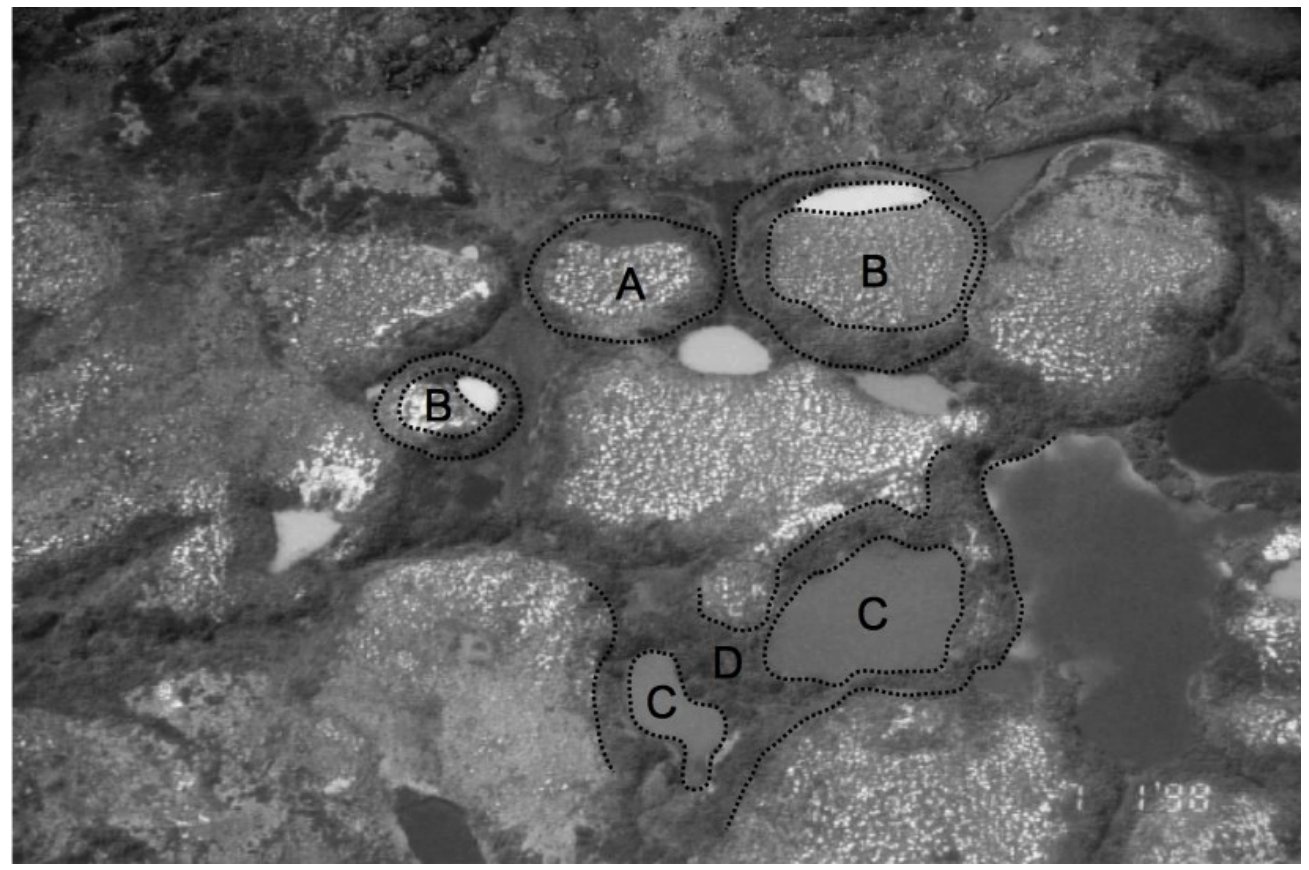

Figure 2.3: Aerial view of a lithalsa field in northern Quebec (Pissart 2002, Figure 1). Many lithalsas are degrading. Examples of lithalsa stages are: A fully formed lithalsa (A). Degrading lithalsas with circular ring ramparts as well as ponds forming on its tops (B). Ponds from fully degraded lithalsas (C) with surrounding ramparts (D). 
next to a pond $70 \mathrm{~m}$ in diameter, which was eroding the lithalsa's side. The sediments that compose the lithalsa appear to have initially been deposited subaqueously within a temporary pond. A proglacial lake may have once covered the study area. Silts were found in the top $0.1 \mathrm{~m}$, and silty clay was noted at depth. The finer grained sediment at depth demonstrates a progressive shallowing of the water body in which the lithalsa formed. As the pond shallowed and terrestrial exposure occurred, permafrost began to penetrate into the fine bottom sediments, enabling ice segregation at depth and the development of a frozen core, resulting in a frost mound.

\subsubsection{Isotopic values within a lithalsa}

$\delta^{18} \mathrm{O}$ values taken from core samples within the lithalsa in the Akkol Valley show little depletion at depth, indicating an open source of groundwater flow to the freezing front in the lithalsa. The $\delta^{18} \mathrm{O}$ values in the permafrost of the lithalsa were between -17.7 and $-14.5 \%$. $\quad \delta^{18} \mathrm{O}$ values from Akkol Lake and the pond by the lithalsa were -13.6 and $11.7 \%$. Akkol Lake is more negative due to the input of meltwater from nearby glaciers (-20 to $-15 \%$ from glacier cores 4 to $12 \mathrm{~m}$ deep). Therefore, Iwahana et al. (2012) suggest that there was little infiltration of meteoric water into the lithalsa's core in recent years and the original source of water for ice in the lithalsa was likely a pond containing melted glacier ice.

\subsubsection{The potential development of a lithalsa from a palsa}

Calmels et al. (2008) instrumented a lithalsa (referred to as BGR) near Umiujaq in Nunavik (northern Quebec) to understand its development and decay process. In contrast to Iwahana et al.'s (2012) lithalsa in the Akkol Valley, Calmels et al. (2008) hypothesized 
that BGR began as a palsa, as the entire wetland area was once covered in unfrozen peat (Figure 2.4a) in a minerotrophic bog or fen that extended over the valley floor.

Successive winters with thin snowfalls prompted horizontal ice lens growth (Figure 2.4b). As the freezing front penetrated deeper, the thermal gradient diminished, promoting the growth of ice lenses over $0.5 \mathrm{~m}$ thick (Calmels et al. 2008). Infiltrating surface water also contributed to lens formation at the top of the permafrost from aggradational ice. Calmels et al. (2008) hypothesize that at some point in the development of BGR, the original palsa's peat cover eroded away (Figure 2.4c). The mound's raised topography increased aeolian erosion and subsequent destruction of the dried out peat cover as blocks of material perhaps slid to the sides of the palsa and were destroyed - an occurrence previously described by Seppälä (1986). Calmels et al. (2008) suggest that continued aeolian erosion of sediment from the lithalsa's top promoted sediment accumulation around its sides. The ice growth, erosion, and surface processes resulted in a frozen silt-clay mound with a high concentration of excess ice in the centre, surrounded by ice-poor mineral sediment with a deep active layer (Figure $2.4 \mathrm{~d}$, e).

\subsubsection{Internal composition}

The internal composition of lithalsas is comparable to that of palsas (Pissart 2002). This was reflected by Allard et al. (1996, p. 225) when, after studying a lithalsa in Nunavik, they stated "the studied plateau is similar to thousands of others and is also comparable (albeit for the absence of peat cover) to thousands of palsas and peat plateaux formed in the Subarctic during the Holocene in clayey silts". Whereas cryosuction from water at depth is responsible for most of a lithalsa's heave (Allard et al. 1996, Pissart 2002) and is a critical factor in lithalsa formation, Allard et al. (1996) also described 
a) Unfrozen initial state

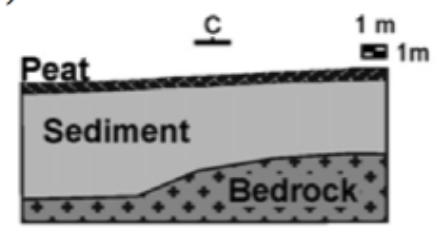

b) Aggradation beginning

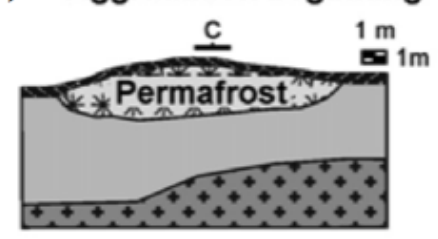

c) Aggradation continued

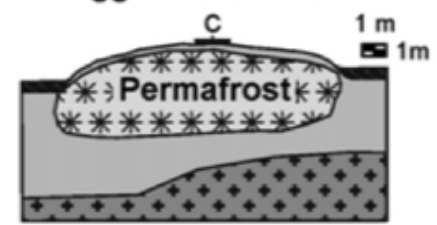

d)

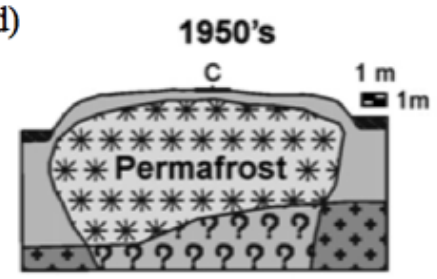

e) September 1, 2000

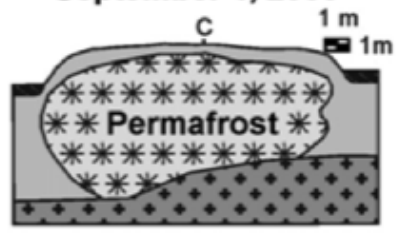

f) Thermokarst beginning

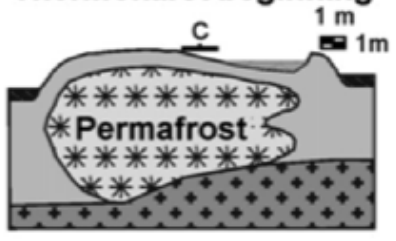

g) Thermokarst continued

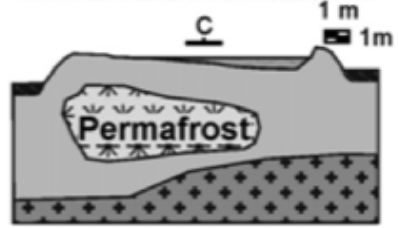

h) Thermokarst pond

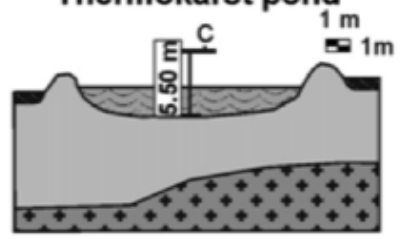

Figure 2.4: Graphic model of key steps in the evolution of the BGR lithalsa, from initial non-permafrost terrain (a) to the actual situation ( $f$ ), and the probable future decay of the lithalsa and the formation of a thermokarst pond ( $g$ and $h$ ). The question marks in (d) refer to the unknown permafrost extension in the bedrock in the past and during the 1950s. Location (c) is a georeferenced point used for topographical measurements since July 2000 (Calmels et al. 2008, Figure 12). 
aggradational ice at the top of permafrost at their study site due to percolation of meteoric water. This ice, only $0.8 \mathrm{~m}$ from the surface, was responsible for $15 \%$ of the mound's total height.

Allard et al. (1996) divided one circular lithalsa's stratigraphy into 3 distinct ground ice units (Figure 2.5). First, below the active layer was the ice-rich top of permafrost where aggradational ice developed. Below the aggradational ice layer, they observed a relatively ice-poor layer $2.5 \mathrm{~m}$ thick containing $1 \mathrm{~mm}$ veins and 10 to $30 \%$ ice volume. Below this layer, a third layer was observed to contain ice 10 to $40 \mathrm{~mm}$ thick with a lens $0.2 \mathrm{~m}$ thick near the permafrost base. Allard et al. (1996) believed ice lenses were continuous throughout the lithalsa, but Pissart (2002) refuted this hypothesis and modified the original diagram from Allard et al. (1996) to reflect discontinuous ice lenses (Figure 2.5).

Iwahana et al. (2012) described the internal structure of the exposure examined in a linear lithalsa as a frozen core with thick reticulate ice lenses and soil segments under a thawed layer of lacustrine sediments 1-1.2 m thick. They also noted lenticular nonparallel wavy ice lenses in the upper section of the lithalsa, but did not report the presence of aggradational ground ice. In general, horizontal or slightly inclined ice layering in lithalsa plateaus arise from thermal gradients that are vertical beneath flat terrain, such as the flattened palsa studied by Allard et al. (1996), whereas ice layering in non-plateau palsas and lithalsas is mostly tilted (Calmels and Allard 2008), such as the lithalsa studied by Iwahana et el. (2012). Much of the ice in Iwahana et al. (2012)'s study was recorded as oblique or slanted.

\subsubsection{Degradation}




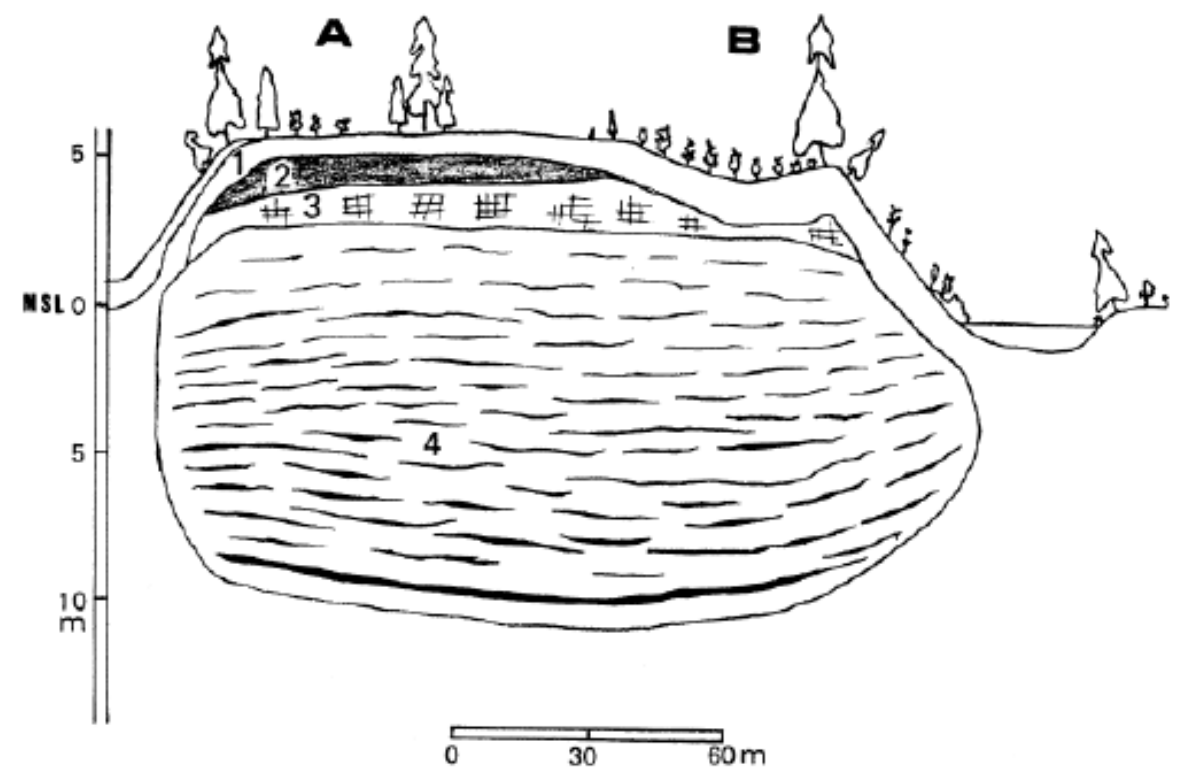

Figure 2.5: Distribution of ice in a lithalsa plateau in northern Quebec described by Pissart (2002, Figure 2) modified from Allard et al. (1996). 1) Active layer; 2) ice-rich layer (50-80\% in volume), aggradational ice; 3) low ice content (10-30\% in volume), reticulate ice; 4) thick and regularly spaced lenses of segregation ice $(50-80 \%$ in volume). Note an ice layer thicker than $0.20 \mathrm{~m}$ near the permafrost base. The figure illustrates vegetation densification (A) and melted aggradational ice (B). 
Degradation of a lithalsa may occur rapidly. Calmels et al. (2008) remarked that the degradation of the lithalsa could be attributed to surface and groundwater flow across the surrounding unfrozen terrain as the incoming heat at the boundary of the permafrost body warms the lithalsa's ice-rich core. Lithalsas may develop crescent-shaped puddles that expand along a similar gradient away from bedrock outcrops (direction of water flow) (Figure 2.4f). Increased snow depth over the settling part of the lithalsa insulates the ground from lower winter air temperatures, inhibiting the release of heat in winter. The increased snow accumulation and ponded water creates a positive feedback that accelerates degradation and induces thaw settlement (Figure 2.4g) (Calmels et al. 2008).

As a lithalsa continues to settle, the crescent-shaped puddle will expand into a pond and a rim-ridge (or rampart), which eventually becomes vegetated, and emerges from the outside edge of the lithalsa (Figure 2.4h). According to Calmels et al. (2008), this rampart formation exists due to aeolian erosion and solifluction, as well as the icepoor nature of the soil due to the slope's prior insulation by snow cover.

\subsubsection{A criticism of aeolian erosion theory}

One problem with Calmels et al.'s (2008) explanation for rampart formation is that aeolian transport and deposition of sediment would likely create disproportionate amounts of sediment on a preferred side of the lithalsa due to prevailing winds. However, the ramparts noted in Calmels et al.'s (2008) study area are symmetrical circular rims. This is inconsistent with aeolian sediment transport being responsible for sediment accumulation to form ramparts. Alternatively, Fortier and Aubé-Maurice (2008) theorize that consolidation of clay sediments in a lithalsa core during ice segregation subsequently results in a depression of several metres after the permafrost 
thaws, leaving only the remnant ringed-shaped rampart of a degraded lithalsa around a central thermokarst pond. Fortier and Aubé-Maurice (2008) noted that consolidation may result in a reduction of as much as $30 \%$ of the original saturated sediment volume at a lithalsa centre. When a lithalsa collapses, a rampart remains, which represents the accumulation of sediment on the sides of the lithalsa due to solifluction.

\subsection{Palsas, lithalsas, and climate change}

The aggradation and degradation of different lithalsas may occur simultaneously within the same given region, due to changes in microclimatic conditions such as snow cover, plant cover, and albedo (Pissart 2002). Much of the literature describes the transient evolution of frost mounds as not necessarily dependent on a changing climate (Seppälä 1982; Dionne 1984; Seppälä 1986, 2006; Calmels et al. 2008). However, palsa and lithalsa behaviour can be an indicator of climate warming due to the sensitive nature of ground ice within the discontinuous permafrost zone. After extensively monitoring a lithalsa in northern Quebec, Delisle et al. (2003) concluded that an increase in water infiltration due to the warming soils (causing active-layer deepening) appeared to be accelerating the overall lithalsa decay process. In Hudson Bay, a rise in lithalsa core temperature coincided with an increase in air temperature between 1990 and 2002 (Calmels et al. 2008).

Permafrost thawing is a long-term process due to the high latent heat of fusion (Fortier and Aubé-Maurice 2008). The inception of lithalsas in the coastal Hudson Bay region reached a peak during cold periods of the Holocene with a maximum extent during the Little Ice Age, but many are now decaying in response to climate warming (Fortier and Aubé-Maurice 2008). Zuidhoff and Kolstrup (2000) note that climatic warming in 
combination with increased snowfall is responsible for the collapsing features of the southernmost palsa field in Sweden. Palsas there lost half their extent between 1960 and 1997 and MAATs have increased in Sweden between 1 to $1.5^{\circ} \mathrm{C}$ since 1930 . Vallée and Payette (2007) also determined that the main climatic driver for increased lithalsa degradation in the Hudson Bay region of northern Quebec is increased snowfall.

Snowfall may also be inconsequential to permafrost decay. Subsurface ground conditions take years to equilibrate with air temperature because permafrost thaw is a long-term effect (Fortier and Aubé-Maurice 2008). A $3{ }^{\circ} \mathrm{C}$ increase in MAATs on the east coast of Hudson Bay from 1983 to 2005 led to significantly increased permafrost degradation rates from the previous 30 years (Fortier and Aubé-Maurice 2008). These changes occurred without any discernable change in mean annual snowfall in the region. Once initiated, permafrost degradation may continue for a length of time, even if cooler climatic conditions return to the region, due to the temporal delay required for a new thermal equilibrium in the ground to be reached (Fortier and Aubé-Maurice 2008).

\subsection{Palsa and lithalsa age}

Perennial frost mounds as witnessed today are generally of Holocene origin, with many lithalsas not exceeding 1500 years in age (Allard et al. 1996, Pissart 2002, 2010; Calmels et al. 2008; Iwahana et al. 2012). Lithalsas do not contain a surface peat cover; therefore obtaining basal organics for radiocarbon dating is not typically possible (Calmels et al. 2008). Instead, contextual knowledge of the region might be used to infer lithalsa ages. For example, Calmels et al. (2008) used historical temperature knowledge of cold periods to estimate formation times as either 1550-1000 BP, or during the Little Ice Age (500-100 BP). 
The succession of vegetation cover (analyzed by the interpretation of aerial photographs, growth rates of shrubs, and dendrochronology) was used by Harris (1993) to determine minimum lithalsa age in southwestern Yukon. Harris (1993) divided lithalsa development into 5 different stages of growth based on vegetation and sedimentation rates with timelines accompanying each stage, and determined that the complete sequence of the lithalsa development in the study area extended through a minimum period of 380 years. The presence of all stages in the study region suggests that conditions were favourable for lithalsa development from about AD 1600 to 1987. Harris (1993) also noted that some of the mature mounds could be substantially older than 380 years.

\subsection{Potential for lithalsas near Yellowknife}

As noted in section 1.3 , there are nearly 1800 potential lithalsas that dot the landscape of the Great Slave Lowlands near Yellowknife (Figure 1.3) (Stevens et al. 2012a, Wolfe et al. 2014). The potential for such extensive lithalsa distribution is due, in part, to the fine-grained sediments that were deposited across the landscape by Glacial Lake McConnell after deglaciation and consequently washed into topographic lows, and by further deposition of material caused by wave washing from ancestral Great Slave Lake as lake recession occurred. Water is also readily available for ice formation at depth from groundwater associated with the many ponds, bogs, fens, and small lakes scattered throughout the region.

Peatlands are located throughout the Great Slave Lowlands, thus the application of Calmels et al.'s (2008) hypothesis that these lithalsas originated from palsas cannot be ruled out without field evidence. Another scenario for the development of lithalsas in the 
Lowlands is that of Iwahana et al. (2012) with frost penetration due to low winter air temperatures after water receded from the site.

Recent annual air temperatures in Yellowknife $\left(-4.6^{\circ} \mathrm{C}\right.$, Environment Canada 2012) fit within the range of reported MAATs at other lithalsa study sites, and suggest that permafrost stabilization at depth is possible in mineral sediments without the need for an insulating peat cover. Through the interpretation of recent aerial photographs, it appears that the Yellowknife region has the potential to contain both mature lithalsas and degraded ramparts (Figure 2.6).

\subsection{Stable isotopes as an indicator of ice lens water sources}

$\delta^{18} \mathrm{O}$ values are inherently dependent on changing weather patterns at a given location influencing the distribution of precipitation, spring melt, and wind direction and intensity, which affect the evaporation rates of water (Moorman et al. 1996). Ice and water around the Earth's surface is composed of precipitation, therefore their isotopic composition will reflect the original precipitation source, and groundwater generally reflects the average annual isotopic composition of the local precipitation shortly after recharge (Michel 2011). The isotopic composition of precipitation generally forms a strong linear relationship between $\delta^{18} \mathrm{O}$ and $\delta^{2} \mathrm{H}$ values to form the global meteoric water line (GMWL); precipitation measured at individual stations varies from the GMWL but still plots along or near it to form the local meteoric water line (LMWL, outlined by Moorman et al. (1996)). Sampled precipitation below the LMWL is commonly a product of evaporation. 


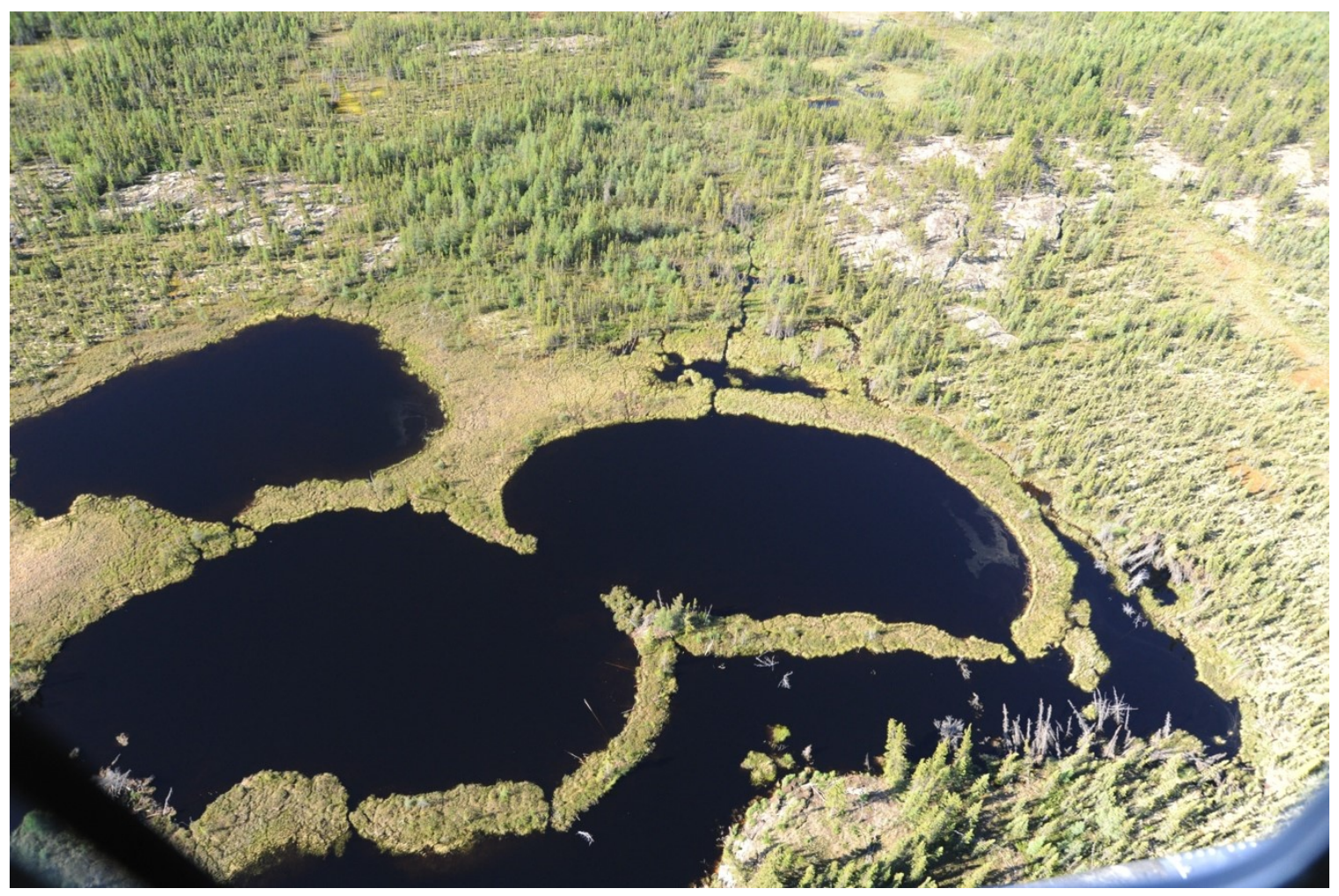

Figure 2.6: Potential ramparts on the landscape near BCSA. The mature spruce trees may be used for scale. 
$\delta^{18} \mathrm{O}$ values of ground ice and local meteoric water may be used to determine water sources for segregated ice at depth and aggradational ice near the surface of the feature (Iwahana et al. 2012). The values may indicate if water is of glacial origin or if waters originate from more modern sources such as meteoric or lake water. The $\delta^{18} \mathrm{O}$ values within the stratigraphic profile also provide clues to the type of system in which water moved into the feature because depletion of $\delta^{18} \mathrm{O}$ is observed within the substrate when water freezes in closed systems (Michel 2011). Conversely, if there is little depletion in $\delta^{18} \mathrm{O}$ throughout the profile, water supply to the freezing front may have been abundant, indicating an open groundwater system (Iwahana et al. 2012). 


\section{Chapter 3 Study region and methods}

\subsection{Study area}

\subsubsection{Regional context}

The study area is in the Great Slave Lowlands, on the northern shore of Great Slave Lake. The Lowlands are part of the Taiga Shield High Boreal (HB) ecoregion (Figure 1.3). They lie between $156 \mathrm{~m}$ a.s.l. (the present level of Great Slave Lake) and about $200 \mathrm{~m}$ a.s.l., and are predominantly west of Yellowknife. The more rugged Great Slave Uplands occur to the east and north of Yellowknife, and rise to about $300 \mathrm{~m}$ a.s.l. (Ecosystem Classification Group 2008). Granitic rocks of the Canadian Shield are found north and west of the city.

The surficial geology of the region is the result of Late Wisconsinan glacial activity. The Laurentide Ice Sheet advanced southwestward, and the Yellowknife area was covered by ice until approximately $11 \mathrm{ka}$ BP (Dyke et al. 2003). The ice sheet retreated to the northeast, and the area became ice-free around $10 \mathrm{ka}$ BP (Kerr and Wilson 2000).

\subsubsection{Glacial Lake McConnell and Great Slave Lake}

Deglaciation was accompanied by development of Glacial Lake McConnell (Figure 1.2), a large pro-glacial lake that formed along the retreating western margin of the ice sheet (Smith 1994). The lake originated in Great Bear Basin, and expanded southwards to fill Great Slave and Athabasca lake basins. As Glacial Lake McConnell rose, the region was flooded to depths of over $100 \mathrm{~m}$. Glaciolacustrine silts and clays deposited in topographic lows on the landscape account for the fine-grained sediments that are distributed across the Lowlands (Wolfe 1998, Stevens et al. 2012a). Glacial Lake 
McConnell was present approximately $11.8-8.3$ cal BP (Smith 1994). Its maximum extent, at approximately $10.7 \mathrm{cal} \mathrm{ka} \mathrm{BP}$, covered about $240,000 \mathrm{~km}^{2}$ and reached an elevation of $235 \mathrm{~m}$ a.s.1. (Smith 1994). As isostatic rebound adjusted surface elevations, Glacial Lake McConnell separated from Great Bear Basin. By 9.5 cal ka BP, water levels fell below $228 \mathrm{~m}$ a.s.1. at the Peace-Athabasca delta and the remaining two basins separated, creating Athabasca Lake and ancestral Great Slave Lake (Lemmen et al. 1994; Smith 1994). Lake levels receded at a rate of approximately $18 \mathrm{~mm} \mathrm{yr}^{-1}$ prior to $7790 \mathrm{cal}$ BP. Recession rates then dropped exponentially over time to a present rate of approximately $2 \mathrm{~mm} \mathrm{yr}^{-1}$ (Vanderburgh and Smith 1988).

\subsubsection{Climate}

North American high-latitude environments have experienced climate warming and cooling throughout the Holocene, including the Holocene Climatic Optimum (6000$4000 \mathrm{cal}$ BP), the First Millennial Cooling (1400 cal BP), the Medieval Climate Anomaly $(1000-700$ cal BP), the Little Ice Age $(550-250$ cal BP), and twentieth-century warming (Mann et al. 2009; Upiter et al. 2014). Climatic cooling events of up to $1{ }^{\circ} \mathrm{C}$ have been reported from southern Alaska at 4000, 3300, 1800-1300, 600, and $250 \mathrm{cal}$ BP (Clegg et al. 2010), and past proxy records have shown mid-late Holocene climate variability in subarctic North America, with particularly highly variable summer temperatures in the last 2000 years (Upiter et al. 2014).

The Great Slave Lowlands have a continental climate, which may be represented by data collected at Yellowknife. The mean annual air temperature at Yellowknife is -4.6 ${ }^{\circ} \mathrm{C}$, and mean total precipitation $281 \mathrm{~mm}$, of which $42 \%$ falls as snow (Environment 
Canada 2012). The mean annual air temperature increased by $0.3{ }^{\circ} \mathrm{C}$ per decade in 1940 1970 and $0.6{ }^{\circ} \mathrm{C}$ per decade since the 1970s (Hoeve et al. 2004; Wolfe et al. 2014).

\subsubsection{Permafrost conditions}

According to Heginbottom et al. (1995), there is widespread discontinuous permafrost in the Lowlands. The presence and condition of the permafrost is variable and sensitive to topography, vegetation, snow accumulation, and subsurface geology. In the Yellowknife region, mean annual ground temperatures (MAGT) at depths to $15 \mathrm{~m}$ vary by up to $2^{\circ} \mathrm{C}$ among different terrain types, being lowest in spruce peatlands where some of the thickest permafrost is found, and highest in bedrock (Brown 1973). Brown (1973) reported MAGT in frozen clayey silts at approximately 3-m depth were between -0.2 to $-0.3^{\circ} \mathrm{C}$, whereas a value of $-0.5^{\circ} \mathrm{C}$ was recorded at a perennially frozen peatland with $1 \mathrm{~m}$ of peat. Permafrost occurs in many peatlands near Yellowknife, and Karunaratne et al. (2008) reported mean annual permafrost temperatures at $1 \mathrm{~m}$ depth in these areas to range between $-0.2^{\circ} \mathrm{C}$ and $-1.9^{\circ} \mathrm{C}$.

Aggradation of permafrost postdates the withdrawal of Glacial Lake McConnell and the lowering of water levels in ancestral Great Slave Lake. Permafrost may have started to form as isolated pockets confined to peatlands either during the Hypsithermal interval, or in the following cold period, perhaps as recently as 4 ka BP (Aspler 1978). Permafrost aggradation around Yellowknife likely occurred within an open groundwater system where sub-permafrost groundwater was linked to existing surface bodies of water (Aspler 1978).

Active-layer depths range between 0.4 and $2.3 \mathrm{~m}$ in the Yellowknife area in association with variations in peat thickness (Aspler 1978). In peatlands, active-layer 
thicknesses are less than $1 \mathrm{~m}$ (Karunaratne et al. 2008; Wolfe et al. 2011). Ground ice in silt and clay is common in the region. In general, the excess ice content in silt and clay is between 5 and $20 \%$ by volume, and in some cases exceeds $80 \%$ (Aspler 1978). A highway study conducted in 1995 indicated potential for deep-seated ground ice in close proximity to the study area with borehole records indicating massive icy bodies up to 5.5 $\mathrm{m}$ thick in the Great Slave Lowland area, with average excess ice contents in the finegrained clays of $20 \%$ (Hoeve et al. 2004).

Reticulate ice veins and stratified ice lenses are the most common cryostructures in the fine-grained mineral soils of the Lowlands. Crosscutting reticulate veins can grow to $70 \mathrm{~mm}$ or more, whereas segregated ice lens thickness commonly varies from $1 \mathrm{~mm}$ to $0.1 \mathrm{~m}$ in finer grained materials (Aspler 1978). Just north of Yellowknife, a soil-free massive icy layer $2.3 \mathrm{~m}$ thick was found near the permafrost table under $2.4 \mathrm{~m}$ of peat, and similar ice bodies more than $1 \mathrm{~m}$ thick have been found in silts under $1.5 \mathrm{~m}$ of peat (Aspler, 1978). Settlement can occur when frozen ground thaws due to the significant volume of ice in excess of the volume of pore space in unfrozen sediment. Thaw settlement and effects of frost heave due to seasonal freezing are the principal engineering challenges for roadways and other infrastructure in the region.

\subsubsection{Boundary Creek Study Area}

The Boundary Creek Study Area (Figure 3.1) is located within the Great Slave Lowlands, and is the site at which fieldwork for this thesis took place. The raised terrain feature investigated at BCSA is over $700 \mathrm{~m}$ in length and lies parallel to NWT Highway 3, approximately $20 \mathrm{~m}$ from the road embankment. Highway 3, built in the mid-1960s, is the road access to Yellowknife. The highway has undergone major reconstruction and re- 
routing since the early 1990s. The last $100 \mathrm{~km}$ of the highway, between Behchoko and Yellowknife, was originally constructed using locally available fine-grained soils (Hoeve et al. 2004). This highway was used until 1999, when construction began on upgrading to a new highway, constructed of blast-rock. Thermal disturbance of ice-rich permafrost along sections of the new highway has contributed to differential settlement of the blastrock embankment (Hoeve et al., 2004; Seto et al., 2012). Subsidence has occurred with this $100-\mathrm{km}$ segment due to the widespread ice-rich permafrost. Permafrost under the road embankment occurs in many places with a ground temperature between $0^{\circ}$ and $-1^{\circ} \mathrm{C}$ and excess ice (Hoeve et al. 2004).

The surface of the investigated feature rises to 3.5 to $4 \mathrm{~m}$ above the surrounding topography. Vegetation on the feature varies, but mature trees, including paper birch, and black and white spruce, grow on the organic surface of deadfall and grasses. A small pond marks the northern boundary of the feature and extends for $50 \mathrm{~m}$ parallel to it. A peatland to the south of the feature is bordered by a bedrock outcrop further south and mixed forest to the east and west (Figure 3.1).

Thermal conditions in the feature at BCSA are presented in Figure 3.2 as a composite of records from a near-surface thermistor cable and a deep thermistor cable approximately $10 \mathrm{~m}$ apart. The ground temperature envelope for one year (September 1, 2012 - August 31,2013 ) indicates a minimum temperature in permafrost at $3.3 \mathrm{~m}$ depth of $-1.6^{\circ} \mathrm{C}$ on May 22,2013 . The mean temperature at $3.3 \mathrm{~m}$ depth is also the lowest in the profile $\left(-1.1^{\circ} \mathrm{C}\right)$. Mean temperature then increases with depth to the terminal thermistor at $10.3 \mathrm{~m}$. The $7.3 \mathrm{~m}$ depth is close to the depth of zero degree annual amplitude because at this depth and below, annual maximum and minimum temperature 


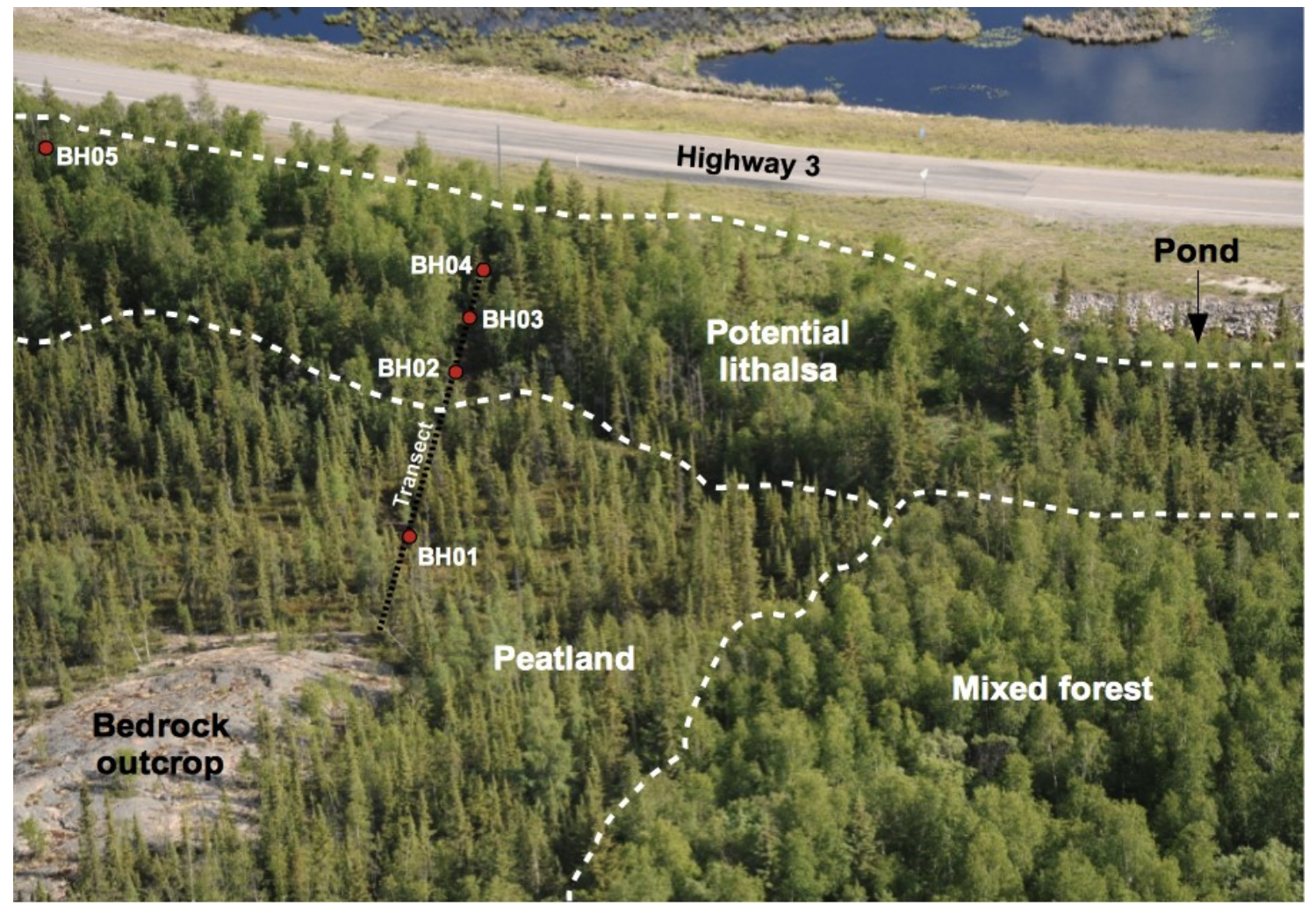

Figure 3.1: Aerial photograph looking northward over BCSA. 


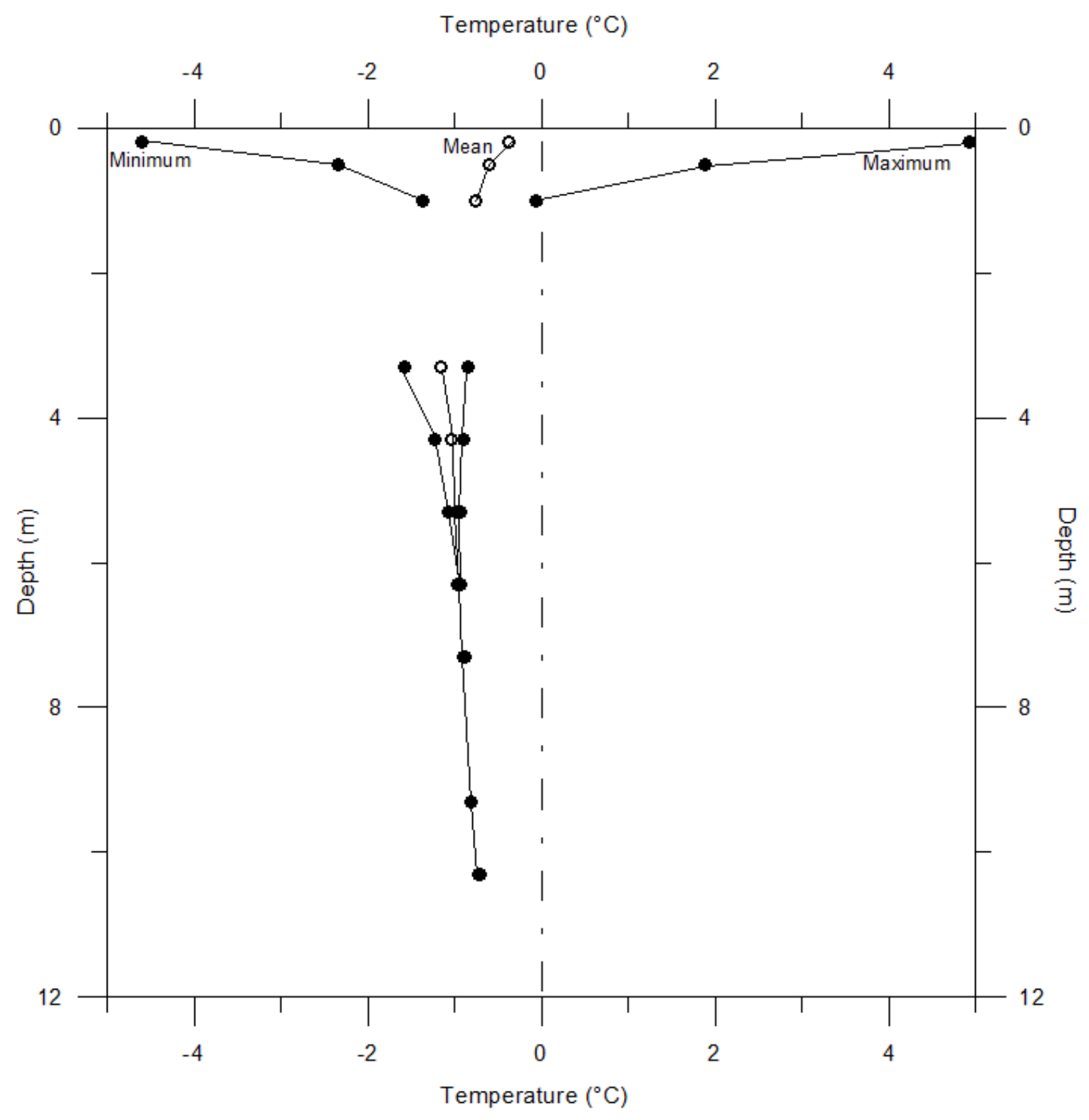

Figure 3.2: A composite of temperatures representing the maximum, minimum, and mean ground thermal conditions for one year (September 1, 2012 - August 31, 2013) at the BCSA feature. Data provided by P. Morse, Geological Survey of Canada. 
varied by $<0.1{ }^{\circ} \mathrm{C}$. The small variation at depth may be due to the latent heat associated with the high apparent heat capacities at the prevailing ground temperatures and low diffusivities of the soil types at BCSA (silts and clays).

\subsubsection{Electrical resistivity}

Oldenborger (2012) evaluated ground ice conditions along the Highway 3 corridor at BCSA using electrical resistivity, and provided data that may be compared with borehole results. Line 1 of Oldenborger's (2012) study ran parallel to the borehole transect (Figure 3.3a), whereas Line 2 ran from the edge of Highway 3, south across a pond adjacent to the feature, over the feature, and into the forested area (Figure 3.3b). Results suggested a potential ice-rich core at the centre of the raised feature, as well as potentially unfrozen conditions at various locations including ground next to the BCSA pond, under the peatland, and under the adjacent forest. Accurate results of ground ice conditions could not be obtained to the depth of bedrock under the feature.

\subsection{Field methods}

Fieldwork was undertaken to determine the characteristics of deep-seated ground ice within the BCSA feature. The field activities included characterizing the study site based on surficial vegetation and visual characteristics, as well as drilling to collect and study soil samples, and to determine depth to bedrock. Soil and water samples were analyzed in the laboratory.

\subsubsection{Creating a transect}

A straight-line transect was created perpendicular to the long axis of the feature at BCSA (Figure 3.1) on which most boreholes were drilled. A cross-sectional profile was 
a)

Number of Iterations: 6

RMS Misfit: $8 \%$

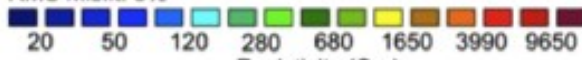

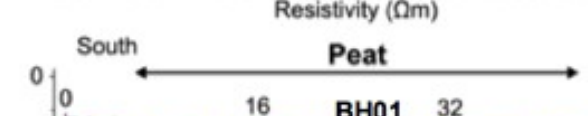

b)

Number of Iterations: 6

RMS Misfit: $8 \%$

$\begin{array}{lllllll}20 & 50 & 120 & \begin{array}{l}280 \\ \text { Resistivity }(\Omega \mathrm{m})\end{array}\end{array}$

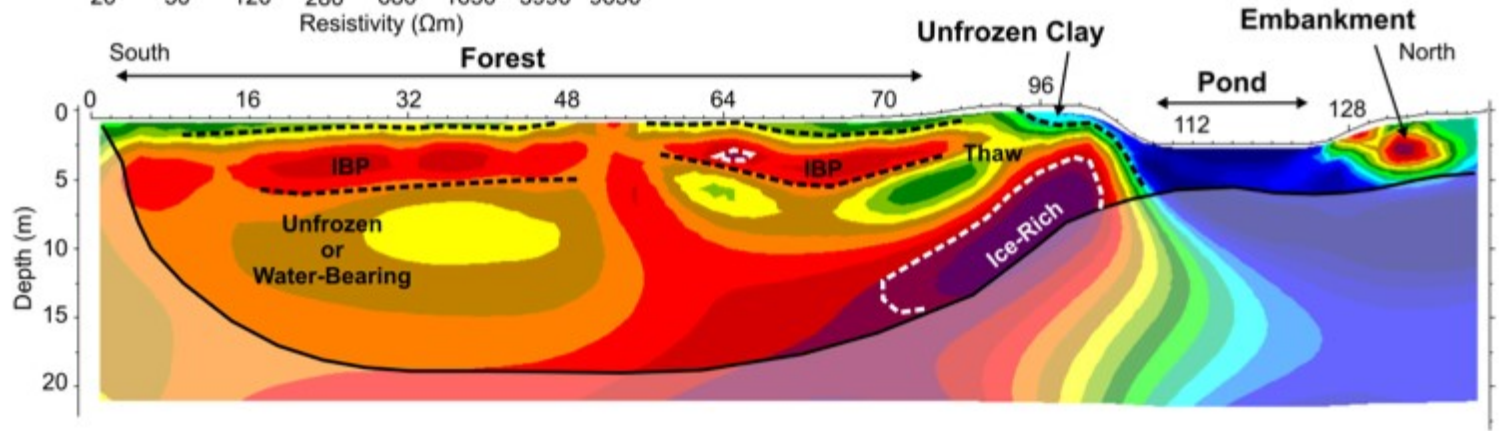

Figure 3.3: Electrical resistivity model and interpretation for a) Line 1 depicting icebonded permafrost and ice-rich zones, as well as areas of thawing at depth along the borehole transect and boreholes BH01-05; and b) Line 2 depicting the highway embankment, pond, unfrozen sediment near the pond and ice-rich clay as well as beneath the forest, and the ice-rich core itself (Oldenborger 2012, Figures 8a and 10a). 
created from LiDAR measurements provided by the Geological Survey of Canada (Figure 3.4). The transect allowed for the comparison of ground conditions between the feature at BCSA and the adjacent peatland.

\subsubsection{Site descriptions}

Detailed surveys of vegetation and surface characteristics were made to help interpret the stability of the underlying permafrost. The location of each borehole was determined by GPS, and distances from different ponds or differing vegetation were noted. Slope angle and drainage extent was recorded. The state of permafrost (stable, aggrading, or degrading) was estimated by noting any surficial thermokarst activity such as ponding or slumping. Site disturbances were recorded. In general, disturbances at BCSA are related to highway infrastructure, including the highway embankment adjacent to the current feature, as well as transmission lines erected directly on the feature (Figure $3.5)$.

\subsubsection{Vegetation surveys}

Ten trees of each species were chosen randomly at each site to measure their height and trunk diameter at chest height. The smaller vegetation including willows, herbs, and heath plants, was also recorded. An approximate ground cover percentage was estimated for each species. This method provided an assessment of the dominant plant species in the area, as well as the dominant ecotype in the study area.

\subsubsection{The active layer}

A steel probe was used to measure the thaw depth before drilling commenced. The probe penetrated unfrozen ground to a maximum depth of $1.30 \mathrm{~m}$. Before drilling, 


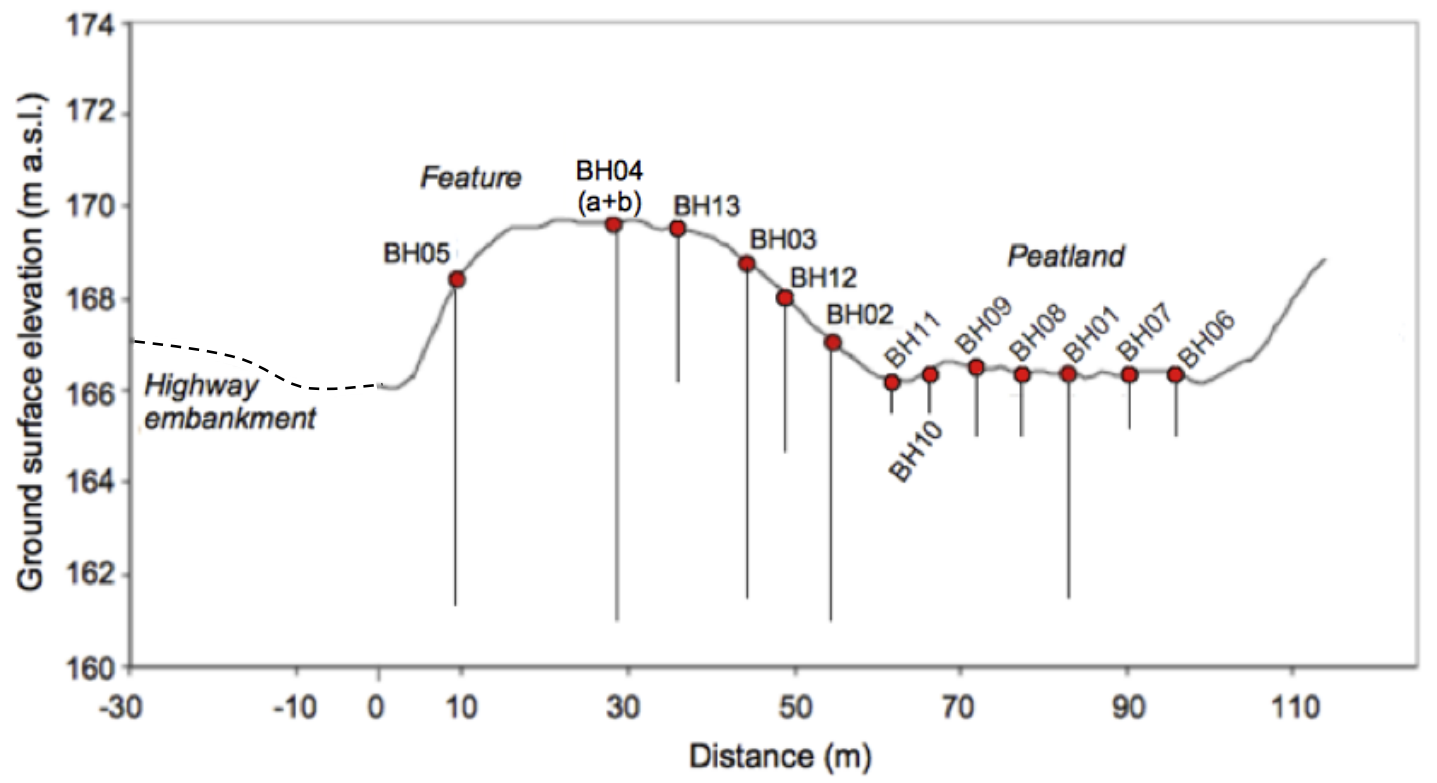

Figure 3.4: Cross-section along the transect of BCSA. LiDAR measurements are from 0 to $115 \mathrm{~m}$ on the $x$-axis. The highway embankment was estimated (0 to $-30 \mathrm{~m}$ on the x-axis). Note: BH05 is approximately $150 \mathrm{~m}$ west of the transect. Approximate borehole depths are indicated at each drill site. 


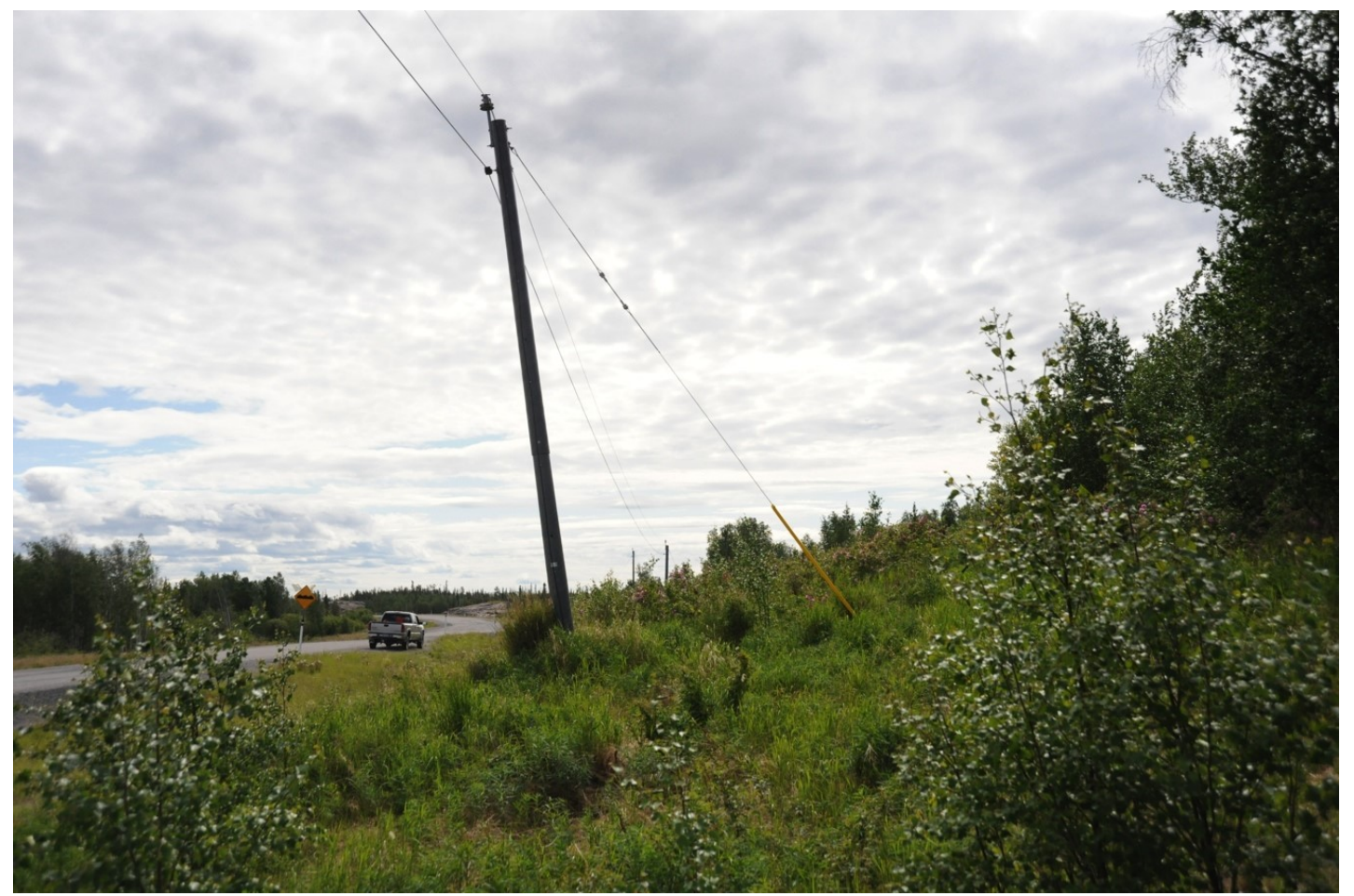

Figure 3.5: Tilted transmission line pole on the north (highway) side of the feature at BCSA. View is east toward Yellowknife. 
nine separate thaw depth measurements were taken at each borehole in a grid pattern and one at the centre of the borehole. All measurements were within a $5 \mathrm{~m}$ radius of the borehole. The average thaw depth was calculated.

\subsubsection{Determining depth to bedrock}

A water jet drill was used to determine the depth to bedrock in the peatland. Highpressure water from a Honda 4-stroke water pump was directed through 3/4" steel pipes. The water source was the nearby BCSA pond (Figure 3.1).

\subsubsection{Boreholes}

\subsubsection{Borehole locations}

Seventeen boreholes were drilled at BCSA. Five were deep boreholes (Figures 3.1, 3.4) extending 4.7-8.4 $\mathrm{m}$ in depth. Four of these were situated along the straight-line transect, with a fifth (BH05) on the north sloping side of the same feature facing the highway, approximately $150 \mathrm{~m}$ west of the transect. The location of BH05 was selected to avoid possible terrain disturbance of the highway cut-slope and the transmission line (Figure 3.5) located near the transect and highway. Ten boreholes up to $3.15 \mathrm{~m}$ in depth were drilled in between the deep boreholes along or close to the transect to help establish the stratigraphy at BCSA. Some of the peat-mineral interfaces were sampled for radiocarbon dating. However, most of the material was not utilized for further analysis. Finally, two shallow boreholes up to $0.85 \mathrm{~m}$ deep were drilled in small pockets of peat on top of the feature 200 and $400 \mathrm{~m}$ west of the transect, in order to collect basal peat dates to establish a timeline for feature development.

\subsubsection{CRREL drill}

A CRREL drill was used to obtain core samples for ground stratigraphy. The 
core-sampler typically returns samples $0.10-0.30 \mathrm{~m}$ in length. An effective method to drill depths greater than $4 \mathrm{~m}$, specifically in clay-rich, ice-poor terrain, was to use a large diameter $(78 \mathrm{~mm})$ and a small diameter $(48 \mathrm{~mm})$ core barrel in sequence. The large core barrel was used to drill as deep as possible before switching to the smaller barrel. When the small core barrel was then used, the sidewall friction and suction were greatly reduced due to the barrel's smaller overall diameter.

\subsubsection{Field sample descriptions}

Once a frozen core sample was extracted from the ground, it was pushed out of the core barrel with a dowel onto a clean board or sheet (Figure 3.6). The sample depth, length and basic physical properties were recorded. Borehole depths were measured with an extendable tape measure. The physical description of the core while in the field included an estimate of soil texture and colour. Any irregularities, including organic materials or stones, were noted in the stratigraphic log and were sampled if required. The general moisture content was noted (desiccated, moist, wet) and the state (thawed, frozen) was recorded.

Visible ice content in each core sample was usually estimated to $+/-5 \%$, and ice conditions in each sample were described based on the cryostructures classifications of Murton and French (1994) (Table 3.1).

\subsubsection{Measurement uncertainties}

Two main measurement uncertainties occurred in the sampling process. First, measurements of thaw depth were made using a probe with markings at 0.10 -m intervals, with measurements of $+/-1 \mathrm{~cm}$. Second, the precision of core sampling is $+/-1-2 \mathrm{~cm}$, primarily due to expansion of peat when removed, and shattering of ice in the core 


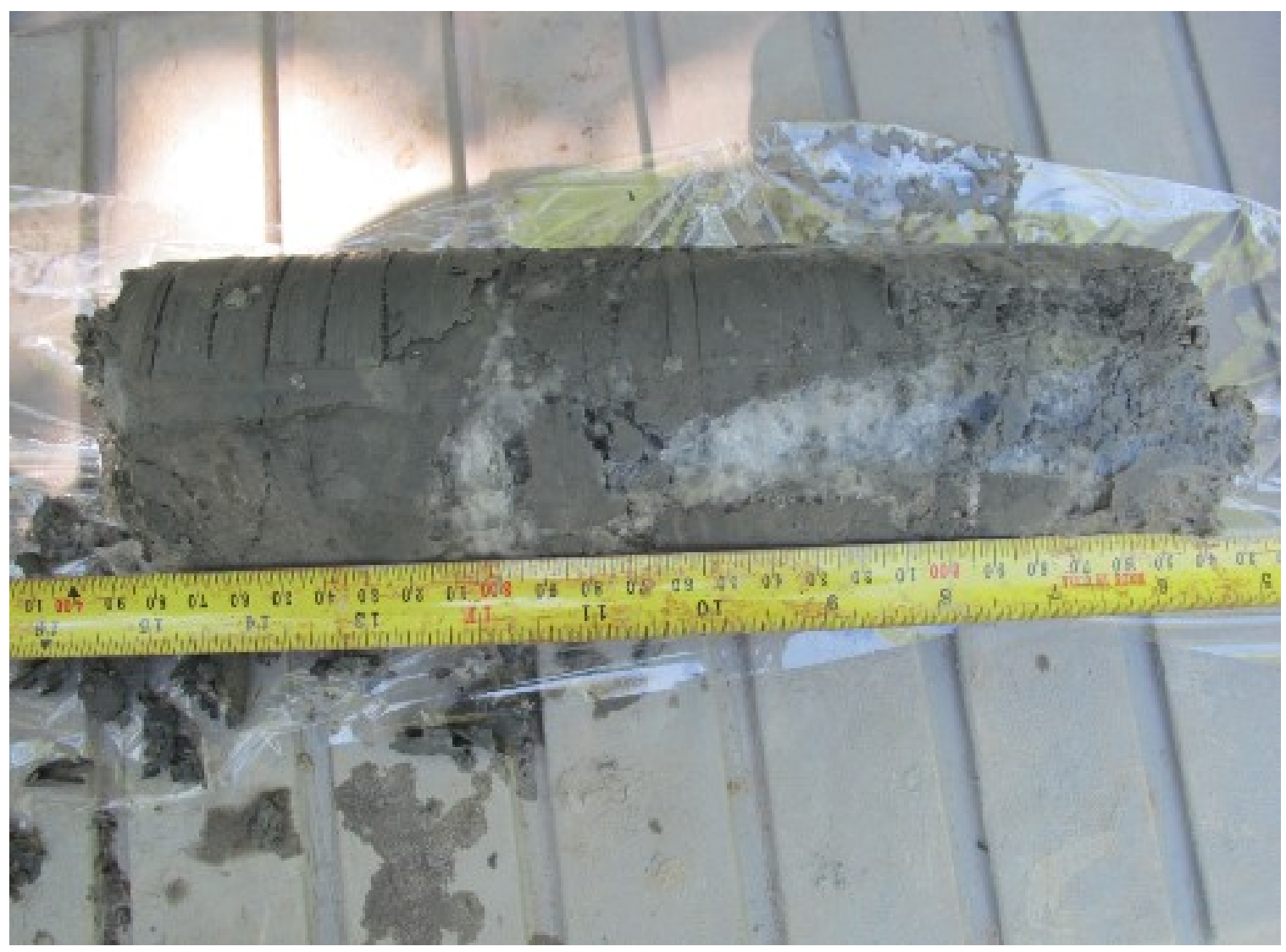

Figure 3.6: A frozen sample with visible ice as retrieved in the field. 
Table 3.1: Cryostructure classifications from Murton and French (1994).

\begin{tabular}{|c|l|}
\hline Cryostructure & \multicolumn{1}{c|}{ Description } \\
\hline Lenticular & $\begin{array}{l}\text { Fens-shaped bodies of ice in sediments. No inclination is implied, and lenses } \\
\text { can vary from horizontal to vertical. Lenticular structures are described by } \\
\text { thickness, shape, inclination, length, and relationship to each other. }\end{array}$ \\
Layered & $\begin{array}{l}\text { Continuous bands of ice, sediment, or combination of both. Layered } \\
\text { cryostructures occur in massive ice, icy sediments, and frost-fissure wedges. } \\
\text { Segregated and intrusive ice may form horizontal to gently-dipping layer at } \\
\text { scales ranging from millimetres to metres. }\end{array}$ \\
Reticulate & $\begin{array}{l}\text { Three-dimensional, net-like structure of ice veins surrounding sediment-rich } \\
\text { blocks. Regular and irregular reticulate cryostructures exist, with the former } \\
\text { appearing as an oriented network surrounding rectangular sediment blocks (a } \\
\text { lattice formation), whereas the latter appears as an irregular network of ice } \\
\text { veins surrounding sediment. }\end{array}$ \\
Crustal & $\begin{array}{l}\text { An ice crust or rim around a rock clast, commonly occurring just beneath the } \\
\text { permafrost table. Crusts up to tens of millimetres may form around pebbles or } \\
\text { wood fragments. } \\
\text { vary from silt to boulders. Suspended cryostructures are common in massive } \\
\text { ice and are common just beneath the permafrost table. }\end{array}$ \\
\hline suspended
\end{tabular}


barrel. A measuring tape was used to verify the borehole depth after each core sample was recovered in order to mitigate uncertainties as drilling progressed.

\subsection{Laboratory methods}

\subsubsection{Bulk Density}

Bulk density, $\rho$, was determined for the sample in its frozen state. The core diameter was recorded based on barrel size, and core length when bagged was noted. Frozen core volume was determined using the formula for the volume of a cylinder:

$$
V=\pi r^{2} h
$$

where $\mathrm{V}$ is volume, $\mathrm{r}$ is the radius of the core sample, and $\mathrm{h}$ is the length of the core sample. With volume determined, the sample weight was divided by the volume to obtain a frozen (wet) bulk density.

The bulk density of a sample is an important measurement as it may be used to interpret the presence of ground ice. Wet bulk density differs from the dry bulk density in that it is strongly dependent on the moisture content of a soil. The density of water is $1.0 \mathrm{~g} \mathrm{~cm}^{-3}$, and is less for ice, with values lower than $0.91 \mathrm{~g} \mathrm{~cm}^{-3}$ possibly due to air inclusions in the ice. Clays have a dry $\rho$ of about $1.45 \mathrm{~g} \mathrm{~cm}^{-3}$, whereas loamy sands can be $1.85 \mathrm{~g} \mathrm{~cm}^{-3}$ (Brady and Weil 2008). At saturation, clays may have a bulk density of

over $1.8 \mathrm{~g} \mathrm{~cm}^{-3}$, therefore frozen bulk densities below this value indicate a greater amount of water, or ice, at depth and should be inversely proportional to ice content.

\subsubsection{Grain-size analysis}

Two rounds of grain-size analyses were conducted during this project. The first was conducted at the Geological Survey of Canada's sediment laboratory. A Retch Technology Camsizer - a Digital Image Analysis (DIA) particle-size analyzer that uses 
two full-frame cameras while employing an LED stroboscope light source - was used to analyze sand-sized particles $(0.063 \mathrm{~mm}$ to $2 \mathrm{~mm})$. The Camsizer's range of particle size is 0.03 to $30 \mathrm{~mm}$; therefore a second instrument was needed for silt and clay sediments (> $0.063 \mathrm{~mm}$ ). For this, a Lecotrac LT100 laser diffraction (LD) particle size analyzer was used. The second round of analyses was conducted at Carleton University using a Beckman Coulter LS 13320 Laser Diffraction (LD) Particle Size Analyzer.

The potential inconsistency of using three different devices to analyze particle size is mitigated because the specific results of sand-sized particles, produced by the DIA method, is not important to this thesis. The main concern was to distinguish the relative proportions of silt- and clay-sized particles. At the diameter of separation $(0.004 \mathrm{~mm})$, both laboratories used the LD method of analysis.

\subsubsection{Excess ice content}

The excess ice content of a soil sample refers to the volume of ice in the ground that exceeds the total pore volume that the ground would have under natural unfrozen conditions (van Everdingen, 1998). One method of determining excess ice content is to allow a sample to thaw in a beaker, then syphon off the supernatant water (Kokelj and Burn 2003, 2005). With the samples collected in this study, the time for settlement was excessive due to the fine-grained nature of the soil. Clay particles remained in suspension for multiple days after being allowed to settle. Further, the fine-grained soils surrounding segregated ice lenses were typically desiccated. This is likely due to the ice segregation process, where moisture is drawn to the ice lens from the surrounding soil. When the ice-rich soil thawed in a beaker, the desiccated soil re-absorbed some of the thawed ice lens water. These factors can affect excess ice results if the Kokelj and Burn 
(2003, 2005) method for excess ice content were used. More error is associated with making visual estimates of excess ice than the Kojelj and Burn (2003, 2005) method, therefore it was imperative to obtain accurate measurements of frozen bulk density from core samples at BCSA.

\subsubsection{Isotopic analysis}

Water samples from sediment pore water and ice lenses at BCSA, as well as samples from adjacent ponds, nearby borrow pits, and rainwater, were sent to the University of Ottawa G.G. Hatch Isotope Laboratory for oxygen and hydrogen stable isotope analysis. $\delta^{18} \mathrm{O}$ and $\delta^{2} \mathrm{H}$ isotopic values provided data for interpretation of the potential water sources for the ice recovered during drilling.

Samples were collected from water bodies with a syringe placed more than 50 $\mathrm{mm}$ below the water surface. Samples from ice lenses were obtained by allowing lenses to thaw in a sample bag, then by using a syringe to extract sample water. The samples were placed in 4,8 , or $30 \mathrm{~cm}^{3}$ vials for laboratory analysis. Initially, all samples were filtered in the field, but this was abandoned due to clay particles in the water samples clogging the filter of the syringe after only a few $\mathrm{mm}^{3}$ of sample had been processed. When samples contained high amounts of sediment, they were left to allow the particles to settle. Supernatant water, which often contained clay particles still in suspension, was sampled without filtering.

In some cases, isotopic samples could not be obtained from samples that were moist but contained too much clay to provide supernatant water. For these samples, a 'muddy' sample was loaded into a titanium press along with a filter paper inserted in the bottom of the press, and squeezed using a hydraulic jack to extract water. This method 
yielded water samples from not only lens water, but also pore water normally held within the clay matrix.

\subsubsection{AMS Radiocarbon dating}

The adjacent peatland and peat deposits on the feature were cored and basal peat dates were obtained from the organic matter at the peat-mineral soil contact. In addition, samples of detrital organics found at depth within the feature and the peatland were collected for data on sedimentation rates. The samples were sent to Beta Analytic Inc. in Miami, Florida for determination of results, which were calculated using the INTCAL09 database.

\subsubsection{Geochemistry}

Geochemical analyses of dried soil samples were conducted at Exova Laboratories in Edmonton, Alberta. The concentrations of $\mathrm{Ca}^{2+}, \mathrm{K}^{+}, \mathrm{Na}^{+}, \mathrm{Mg}^{2+}, \mathrm{Cl}^{-}$and $\mathrm{SO}_{4}{ }^{2-}$ were provided in $\mathrm{mEq} / \mathrm{L}$. These data provided information on the chemical composition of the soil within the feature and adjacent peatland, evidence of past thaw events, and solute movement through the substrate in relation to soil stratigraphy and water migration.

\subsubsection{Moisture content}

Moisture contents of samples were calculated but not used in this thesis. Moisture content results are displayed in Appendix A. A 20-30 mm thick slice of sample was collected from each core for moisture content analysis upon return from the study site each day. The remaining sample, with measured length and known diameter, was used for bulk density analysis and other laboratory tests. Sample bags were sealed and 
allowed to thaw during transport away from the field. Soil moisture content was determined on a wet gravimetric basis using a portable drying oven.

\subsection{Summary}

This chapter has provided an overview of the study region by describing the current and past climatic and geomorphic conditions of the Great Slave Lowlands, its recent post-glacial history including sediment deposition due to the influence of Glacial Lake McConnell, and permafrost conditions near the study site. An overview of Boundary Creek Study Area was also provided and included recent ground temperature measurements indicating warm permafrost. Field sampling methods and laboratory analysis procedures were also defined. The ensuing chapter presents the results of the fieldwork undertaken at BCSA, as well as the results of the subsequent laboratory analyses. 


\section{Chapter 4 Results}

The results of fieldwork undertaken at BCSA are presented in this chapter, including site descriptions and investigations of sub-surface cryostratigraphy. The chapter presents frozen bulk density $(\rho)$, cryostructures, isotopic and geochemical analysis, and AMS radiocarbon dates. Discussion of these results is provided in Chapter 5.

\subsection{Local Site Conditions}

\subsubsection{Introduction}

The surficial and sub-surface conditions at each of the five deep boreholes drilled at BCSA, as well as supplemental sub-surface conditions at two shallow (3-3.15 m) boreholes, establish the state of permafrost at BCSA and provide contextual information for discussion of the feature's development and growth (Table 4.1).

\subsubsection{The peatland}

\subsubsection{Surficial conditions}

Overall ecotype: black spruce - Labrador tea peatland (Figure 4.1). Borehole BH01 was located in an open peatland south of the frost mound at the BCSA. The thaw depth on 12 August, 2011, was $0.36 \mathrm{~m}$, the minimum value obtained in the area. The surface was undisturbed. The site sloped approximately $2^{\circ}$ to the southeast. Exposed bedrock was located $20 \mathrm{~m}$ south of the borehole (Figure 3.4), and the borehole was located $20 \mathrm{~m}$ south of the toe of the feature. There was evidence of an old fire. The terrain was undulating, with $0.3 \mathrm{~m}$ of micro-relief. Small ( $4 \mathrm{~m}$ in height) black spruce trees (Picea mariana) were the dominant vegetation, accounting for $20 \%$ of land cover. 
Table 4.1: An overview of surficial conditions at BCSA.

\begin{tabular}{|c|c|c|c|c|c|c|}
\hline Site & $\begin{array}{l}\text { Thaw } \\
\text { depth } \\
\text { (m) }\end{array}$ & $\begin{array}{c}\text { Organic } \\
\text { layer } \\
\text { (m) }\end{array}$ & $\begin{array}{c}\text { Drainage } \\
\text { Extent }\end{array}$ & Overall ecotype & $\begin{array}{l}\text { Slope } \\
\left({ }^{\circ}\right)\end{array}$ & $\begin{array}{l}\text { Irregularities/ } \\
\text { disturbances }\end{array}$ \\
\hline BH01 & 0.36 & 0.93 & $\begin{array}{l}\text { Dry for } 0.05 \\
m \text { then wet }\end{array}$ & $\begin{array}{c}\text { Black spruce - } \\
\text { Labrador tea peatland }\end{array}$ & 2 & Evidence of old fire \\
\hline BH02 & 0.83 & 0.1 & $\begin{array}{l}\text { Dry, well- } \\
\text { drained }\end{array}$ & $\begin{array}{l}\text { Open birch - white } \\
\text { spruce woodland }\end{array}$ & 15 & $\begin{array}{c}\text { Depressions } 0.2 \mathrm{~m} \\
\text { deep }\end{array}$ \\
\hline BH03 & 0.7 & 0.15 & $\begin{array}{l}\text { Dry, well- } \\
\text { drained }\end{array}$ & $\begin{array}{l}\text { Open birch - white } \\
\text { spruce woodland }\end{array}$ & 15 & $\begin{array}{c}\text { Cracks } 0.1 \text { to } 0.15 \\
\text { m deep }\end{array}$ \\
\hline $\begin{array}{l}\mathrm{BH} 04 \\
(\mathrm{a}+\mathrm{b})\end{array}$ & 0.97 & 0.3 & $\begin{array}{l}\text { Damp, well- } \\
\text { drained }\end{array}$ & Birch forest & $<5$ & $\begin{array}{c}\text { Cracks } 0.1 \text { to } 0.3 \mathrm{~m} \\
\text { deep }\end{array}$ \\
\hline BH05 & 1.3 & 0.2 & Damp & $\begin{array}{l}\text { Mixed black spruce - } \\
\text { birch forest }\end{array}$ & 20 & $\begin{array}{c}\text { Permafrost } \\
\text { degrading, } \\
\text { hummocky terrain }\end{array}$ \\
\hline
\end{tabular}




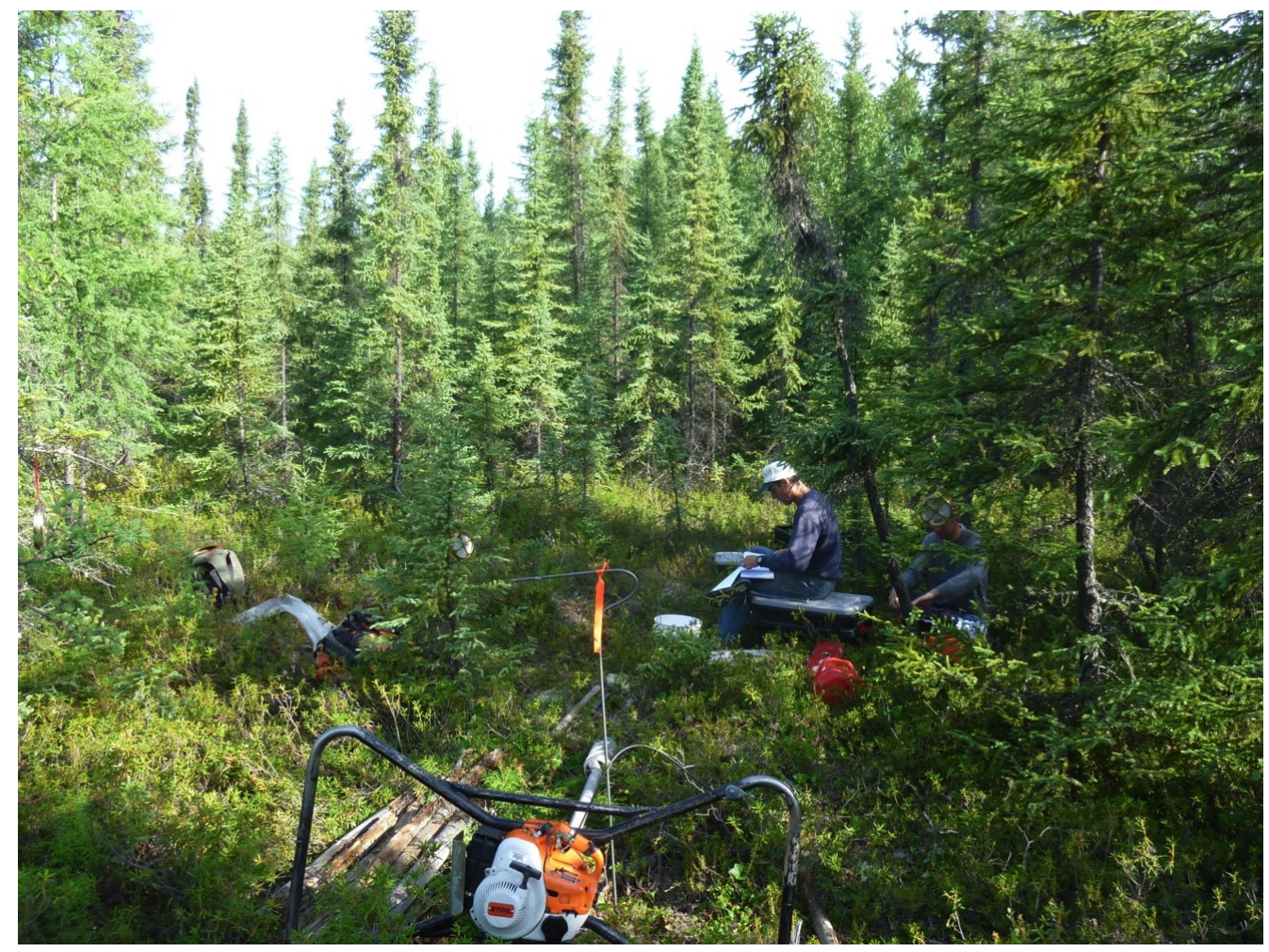

Figure 4.1: View of drill site BH01 facing north. 
Tamarack trees (Larix laricina) $3 \mathrm{~m}$ in height were also present (5\% cover). Labrador tea (Rhododendron tomentosum) covered $50 \%$ of the ground surface.

\subsubsection{Sub-surface conditions}

Figure 4.2 presents the stratigraphy, $\rho$, cryostructures, VI, and $\delta^{18} \mathrm{O}$ values at BH01. Dry peat covered the ground surface to less than $0.05 \mathrm{~m}$ depth, and moist peat extended to a depth of $0.30 \mathrm{~m}$. Beneath the thaw depth of $0.30 \mathrm{~m}$, frozen peat with no VI extended to $0.93 \mathrm{~m}$. Below the frozen peat, fine-grained mineral material occurred, and visible ice generally appeared as thin $(1 \mathrm{~mm})$ reticulate veins and $1-5 \mathrm{~mm}$ lenticular lenses in silty sand. Average $\rho$ was $1.89 \mathrm{~g} \mathrm{~cm}^{-3}$. VI was negligible from 2.05 to $2.50 \mathrm{~m}$.

A layer of clayey silt occurred beneath the silty sand at $3.20 \mathrm{~m}$, and small lenticular lenses 1 to $5 \mathrm{~mm}$ thick were common. A transition to dense grey clay occurred at $4.30 \mathrm{~m}$, and multiple $15-20 \mathrm{~mm}$ thick lenses occurred between depths of 4.38 and 4.70 $\mathrm{m}$, with the clay above and below this ice appearing largely desiccated. Values of $\delta^{18} \mathrm{O}$ were most negative in near-surface peat $(-22.7 \%$ at $0.45 \mathrm{~m}$ depth), became less negative in frozen peat (-16.8\%o at $0.81 \mathrm{~m}$ depth) then decreased at $1.25 \mathrm{~m}$ and remained stable in silty sand to about $1.25 \mathrm{~m}$. A $\delta^{18} \mathrm{O}$ value of $-18.7 \%$ in clay was recovered at $4.48 \mathrm{~m}$ and was similar to the values recovered in the lower silty sand. Total ice thickness per $0.50 \mathrm{~m}$ depth and cumulative ice thickness with depth are presented in Table 4.2a.

\subsubsection{The frost mound}

In general, the ecotype along the transect across the frost mound was an open birch - white spruce woodland. This area was dry and well drained. Areas of open canopy woodland with exposed bare ground occurred adjacent to more densely populated 

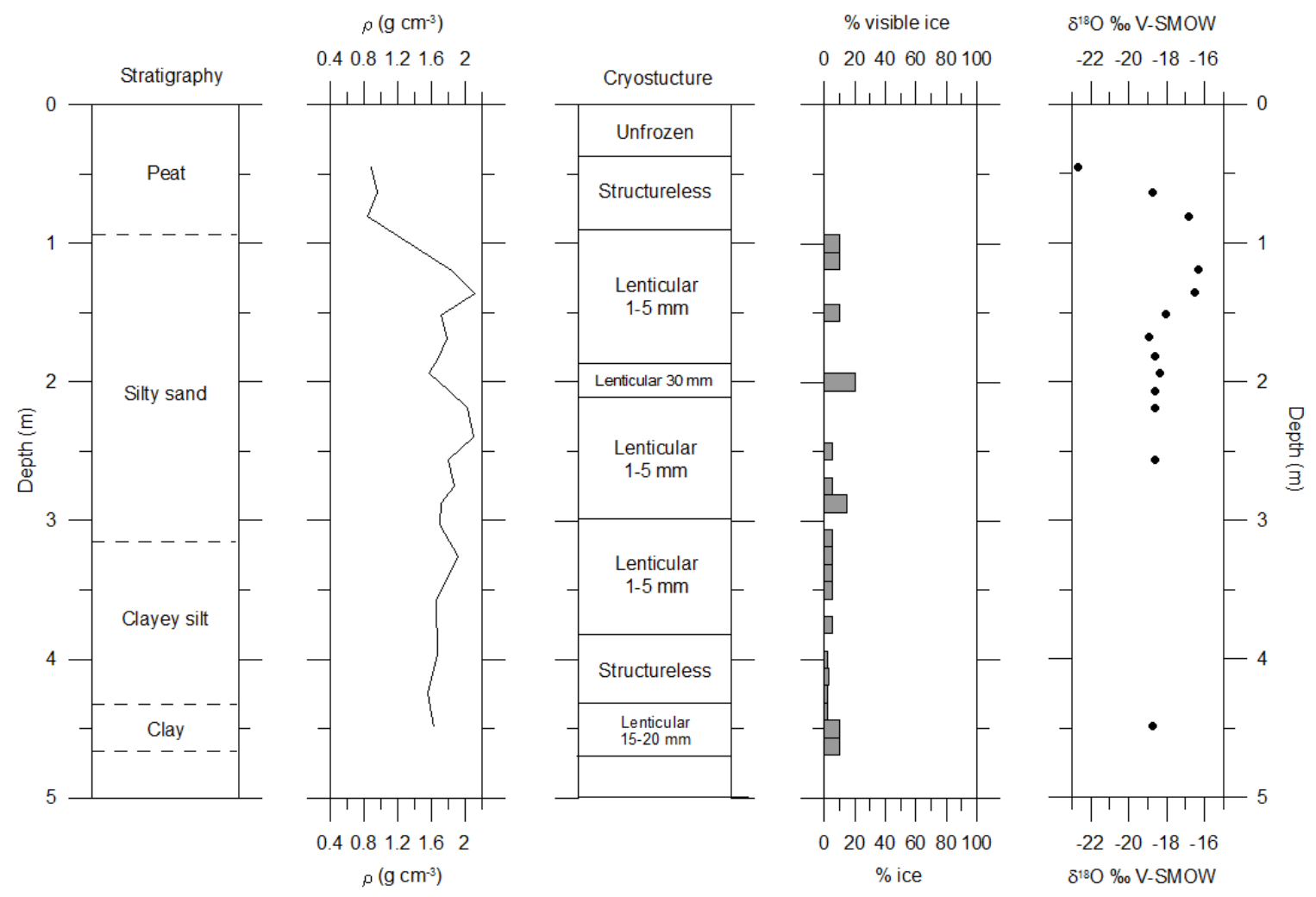

Figure 4.2: Stratigraphy, frozen bulk density ( $\rho)$, cryostructures, visible ice, and $\delta^{18} \mathrm{O}$ values at $\mathrm{BHO1}$ (peatland). 
Table 4.2: Ice thickness per $0.5 \mathrm{~m}$ depth increment based on visible ice and borehole log records, and cumulative ice lens thickness with depth in boreholes a ) BHO1; to e) $\mathrm{BHO5}$.

a)

\begin{tabular}{|c|c|c|}
\hline \multicolumn{3}{|c|}{ BH01 } \\
\hline Depth (m) & $\begin{array}{c}\text { Ice } \\
\text { thickness } \\
\text { per 0.5 m }\end{array}$ & $\begin{array}{c}\text { Cumulative } \\
\text { ice thickness } \\
\text { (m) }\end{array}$ \\
\hline $0-0.5$ & 0 & 0 \\
$0.5-1$ & 0.01 & 0.01 \\
$1-1.5$ & 0.03 & 0.04 \\
$1.5-2$ & 0.02 & 0.06 \\
$2-2.5$ & 0.01 & 0.07 \\
$2.5-3$ & 0.04 & 0.11 \\
$3-3.5$ & 0.03 & 0.14 \\
$3.5-4$ & 0.02 & 0.16 \\
$4-4.5$ & 0.05 & 0.21 \\
$4.5-4.7$ & 0.04 & 0.25 \\
\hline
\end{tabular}

b)

\begin{tabular}{|c|c|c|}
\hline \multicolumn{3}{|c|}{ BH02 } \\
\hline Depth (m) & $\begin{array}{c}\text { Ice } \\
\text { thickness } \\
\text { per 0.5 m }\end{array}$ & $\begin{array}{c}\text { Cumulative } \\
\text { ice thickness } \\
\text { (m) }\end{array}$ \\
\hline $0-0.5$ & 0 & 0 \\
$0.5-1$ & 0 & 0 \\
$1-1.5$ & 0.02 & 0.02 \\
$1.5-2$ & 0.04 & 0.06 \\
$2-2.5$ & 0.03 & 0.09 \\
$2.5-3$ & 0.03 & 0.12 \\
$3-3.5$ & 0.02 & 0.14 \\
$3.5-4$ & 0.05 & 0.19 \\
$4-4.5$ & 0.03 & 0.22 \\
$4.5-5$ & 0.06 & 0.28 \\
$5-5.5$ & 0.12 & 0.40 \\
$5.5-6$ & 0.27 & 0.67 \\
\hline \multicolumn{2}{|c}{} \\
\hline
\end{tabular}

c)

\begin{tabular}{|c|c|c|}
\hline \multicolumn{3}{|c|}{ BH03 } \\
\hline Depth (m) & $\begin{array}{c}\text { Ice } \\
\text { thickness } \\
\text { per 0.5 m }\end{array}$ & $\begin{array}{c}\text { Cumulative } \\
\text { ice thickness } \\
\text { (m) }\end{array}$ \\
\hline $0-0.5$ & 0 & 0 \\
$0.5-1$ & 0 & 0 \\
$1-1.5$ & 0 & 0 \\
$1.5-2$ & 0.05 & 0.05 \\
$2-2.5$ & 0.06 & 0.11 \\
$2.5-3$ & 0.08 & 0.19 \\
$3-3.5$ & 0.06 & 0.25 \\
$3.5-4$ & 0.13 & 0.38 \\
$4-4.5$ & 0.08 & 0.46 \\
$4.5-5$ & 0.07 & 0.53 \\
$5-5.5$ & 0.21 & 0.74 \\
$5.5-6$ & 0.19 & 0.93 \\
$6-6.5$ & 0.15 & 1.08 \\
$6.5-7.02$ & 0.14 & 1.22 \\
\hline
\end{tabular}

d)

\begin{tabular}{|c|c|c|}
\hline \multicolumn{3}{|c|}{ BH04 } \\
\hline Depth (m) & $\begin{array}{c}\text { Ice } \\
\text { thickness } \\
\text { per 0.5 m }\end{array}$ & $\begin{array}{c}\text { Cumulative } \\
\text { ice thickness } \\
\text { (m) }\end{array}$ \\
\hline $0-0.5$ & 0 & 0 \\
$0.5-1$ & 0.00 & 0 \\
$1-1.5$ & 0.03 & 0.03 \\
$1.5-2$ & 0.04 & 0.07 \\
$2-2.5$ & 0.07 & 0.14 \\
$2.5-3$ & 0.07 & 0.21 \\
$3-3.5$ & 0.06 & 0.27 \\
$3.5-4$ & 0.09 & 0.36 \\
$4-4.5$ & 0.15 & 0.51 \\
$4.5-5$ & 0.21 & 0.72 \\
$5-5.5$ & 0.17 & 0.89 \\
$5.5-6$ & 0.06 & 0.95 \\
$6-6.5$ & 0.10 & 1.05 \\
$6.5-7$ & 0.30 & 1.35 \\
$7-7.5$ & 0.20 & 1.55 \\
$7.5-8$ & 0.34 & 1.89 \\
$8-8.4$ & 0.28 & 2.17 \\
\hline
\end{tabular}

e)

\begin{tabular}{|c|c|c|}
\hline \multicolumn{3}{|c|}{ BH05 } \\
\hline Depth (m) & $\begin{array}{c}\text { Ice } \\
\text { thickness } \\
\text { per 0.5 m }\end{array}$ & $\begin{array}{c}\text { Cumulative } \\
\text { ice thickness } \\
\text { (m) }\end{array}$ \\
\hline $0-0.5$ & 0 & 0 \\
$0.5-1$ & 0 & 0 \\
$1-1.5$ & 0.01 & 0.01 \\
$1.5-2$ & 0.14 & 0.15 \\
$2-2.5$ & 0.08 & 0.23 \\
$2.5-3$ & 0.07 & 0.3 \\
$3-3.5$ & 0.14 & 0.44 \\
$3.5-4$ & 0.16 & 0.6 \\
$4-4.5$ & 0.16 & 0.76 \\
$4.5-5$ & 0.11 & 0.87 \\
$5-5.5$ & 0.10 & 0.97 \\
$5.5-6$ & 0.30 & 1.27 \\
$6-6.5$ & 0.34 & 1.61 \\
$6.5-7$ & 0.21 & 1.82 \\
$7-7.5$ & 0.24 & 2.06 \\
\hline
\end{tabular}


paper birch (Betula papyrifera) and white spruce (Picea glauca) forest. Ground cover at borehole sites on the transect $(\mathrm{BH} 02$ to $\mathrm{BH} 04 \mathrm{a}+\mathrm{b})$ consisted of small patches of prickly rose (Rosa acicularis), fireweed (Chamerion angustifolium), and dwarf dogwood (Cornus canadensis) within open areas of deadfall and bare ground. On the south side of the transect, there were dense patches of prickly rose. West of the transect, the south side of the feature (BH05) was more moist.

\subsubsection{BH02 surficial conditions}

Overall ecotype: open birch - white spruce woodland (Figure 4.3a). BH02 was located on the feature, $5 \mathrm{~m}$ from the toe (Figure 3.4). The thaw depth on 12 August, 2011, was $0.83 \mathrm{~m}$. The ground surface was well drained. There was light disturbance due to tree cutting, but no evidence of fire. Some small depressions less than $1 \mathrm{~m}$ in diameter and $0.2 \mathrm{~m}$ deep occurred at the surface. The slope was approximately $15^{\circ}$ upward to the north. Tall ( $8 \mathrm{~m}$ high) mature paper birch and tall $(9 \mathrm{~m}$ high) mature white spruce each accounted for approximately $10 \%$ ground cover.

\subsubsection{BHO2 sub-surface conditions}

Figure 4.4 presents the stratigraphy, $\rho$, cryostructures, VI, and $\delta^{18} \mathrm{O}$ values at BH02. Dry organics extended to $0.32 \mathrm{~m}$. Frozen clayey silt was ice-poor to $1.23 \mathrm{~m}$. Small ice lenses occurred to $1.39 \mathrm{~m}$. Below this layer, until a depth of $3.78 \mathrm{~m}$, VI did not exceed $5 \%$. Ice-poor clay extended to $4.99 \mathrm{~m}$. The clayey silt - clay interface appeared at $4.95 \mathrm{~m}$ and thin horizontal lenses 1 to $10 \mathrm{~mm}$ thick were common to $5.55 \mathrm{~m}$. Below this, thick $(80-220 \mathrm{~mm})$ layers of ice with stiff clay were present to $6.0 \mathrm{~m}$, with VI ranging from $50-90 \%$. The most negative $\delta^{18} \mathrm{O}$ value was in clayey silt (-18.8 \%o at $\left.1.3 \mathrm{~m}\right)$. Values increased up to $-16.3 \%$ at $2.27 \mathrm{~m}$ then generally trended more negatively to the 
a)

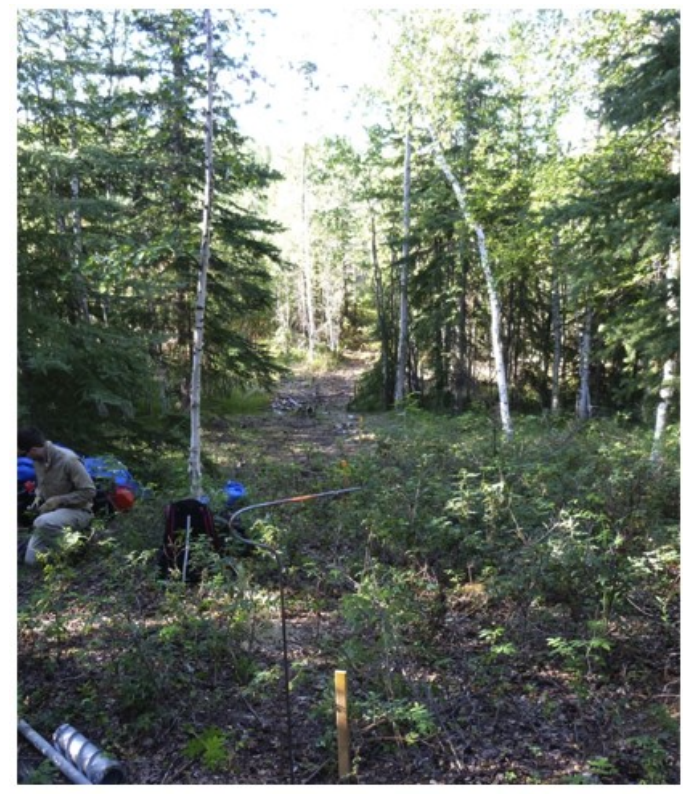

c)

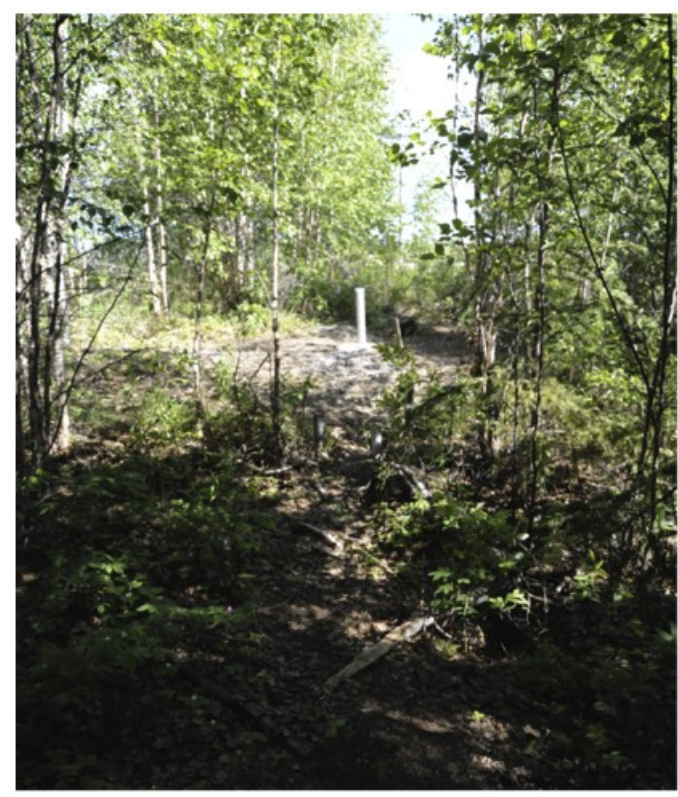

b

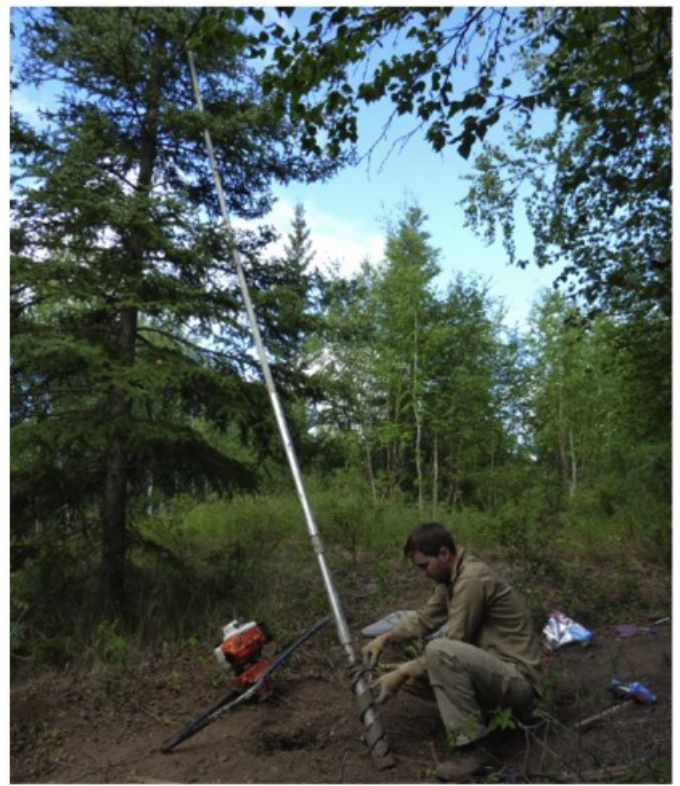

d)

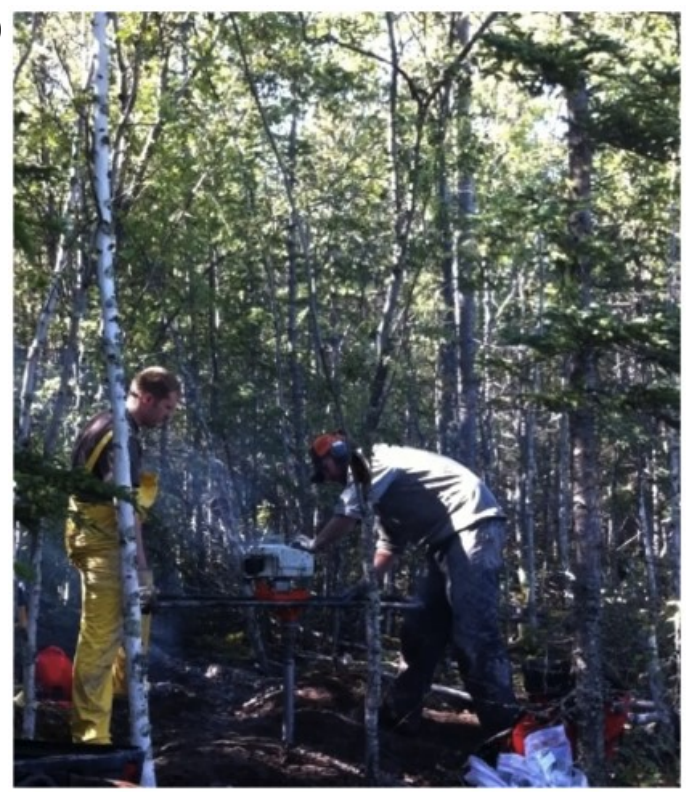

Figure 4.3: View of drill sites a) BHO2 facing south along the transect toward the peatland; b) BHO3 facing north on the transect; c) BHO4b facing north on the transect; and d) BHO5 off the transect facing east. 

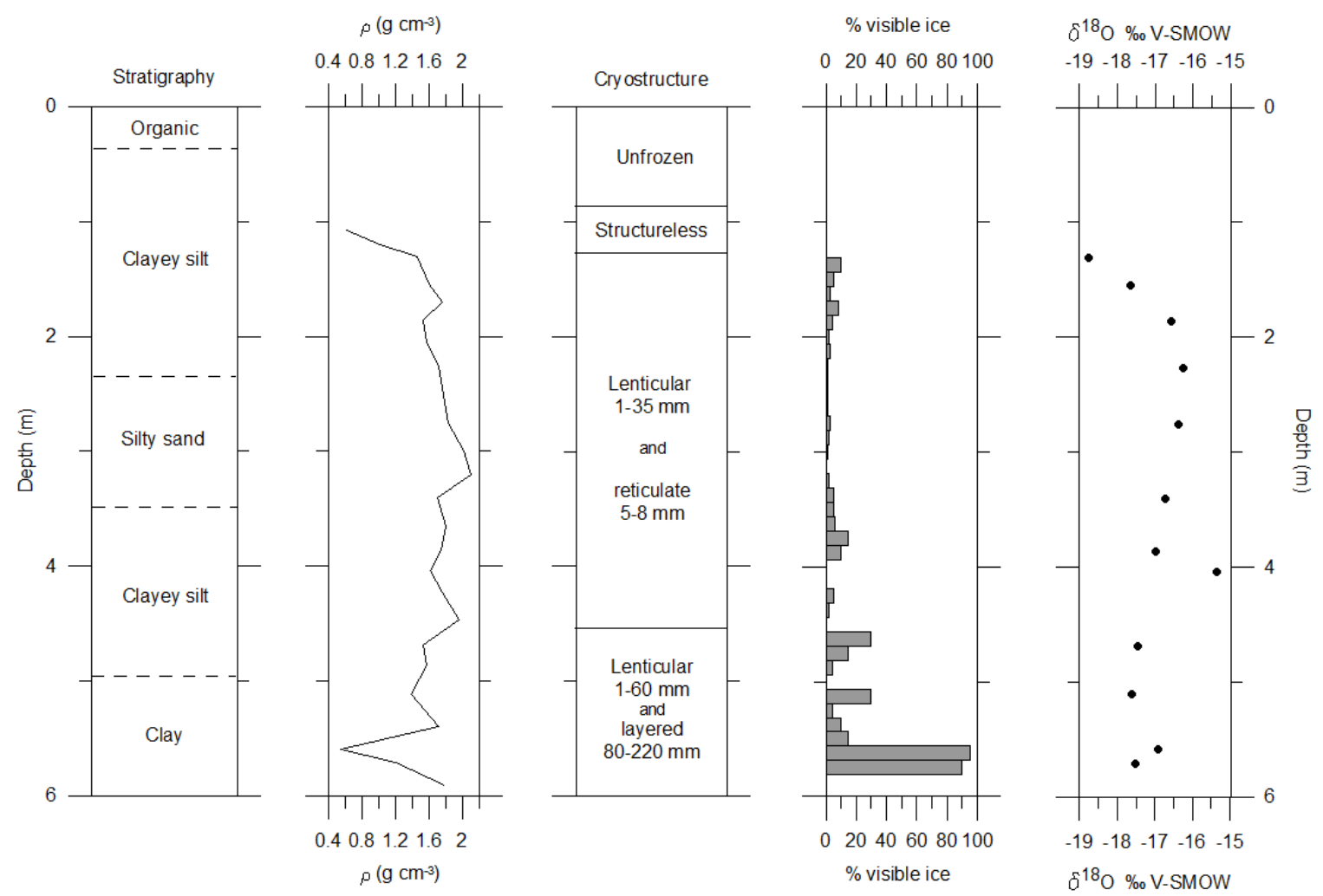

Figure 4.4: Stratigraphy, frozen bulk density ( $\rho)$, cryostructures, visible ice, and $\delta^{18} O$ values at BHO2 (edge of feature; approximately $1 \mathrm{~m}$ above peatland). 
base of the borehole $(-16.9 \%$ at $5.59 \mathrm{~m})$. Total ice thickness per $0.50 \mathrm{~m}$ depth and cumulative ice lens thickness with depth are presented in Table 4.2b.

\subsubsection{BH03 surficial conditions}

Overall ecotype: open birch - white spruce woodland (Figure 4.3b). Borehole BH03 was located approximately two-thirds of the way to the top of the feature, $10 \mathrm{~m}$ north of BH02 (Figure 3.4). The dry organic surface cover extended to a depth of 0.15 m. Surface conditions were similar to BH02. Cracks and fissures in the ground were 0.1 to $0.15 \mathrm{~m}$ in depth. The site sloped approximately $15^{\circ}$ upwards towards the north. The thaw depth on 9 August, 2011, was $0.67 \mathrm{~m}$. Tall, mature paper birch (15\% cover) $11 \mathrm{~m}$ in height and white spruce (10\% cover) $10 \mathrm{~m}$ in height were the large tree species, and rose bushes and fireweed were abundant (each covering $20 \%$ ).

\subsubsection{BH03 sub-surface conditions}

Figure 4.5 indicates stratigraphy, $\rho$, cryostructures, VI, and $\delta^{18} \mathrm{O}$ values of $\mathrm{BH} 03$. The ground surface at BH03 was composed of dry brown organics, and extended to 0.50 m. Dry, brown, unfrozen silty clay occurred to the thaw depth $(0.67 \mathrm{~m})$. Below this, icepoor sticky clayey silt occurred to $1.61 \mathrm{~m}$. A clayey silt - silty sand interface occurred at $2.20 \mathrm{~m}$. Reticulate cryostructures between $1-10 \mathrm{~mm}$ were common to $2.68 \mathrm{~m}$, and increased in thickness to $20-40 \mathrm{~mm}$ at $4.11 \mathrm{~m}$. At $3.5 \mathrm{~m}$ depth, the sediment texture returned to clayey silt, and at $5.05 \mathrm{~m}$ transitioned to clay.

An ice-poor section of the profile appeared from 4.26 to $5.0 \mathrm{~m}$ depth. From 5.0 to $7.0 \mathrm{~m}$, stiff clays and ice lenses up to $140 \mathrm{~mm}$ thick were layered, reflecting widely varying VI. Relatively high $\rho$ in the clays reflect this trend (up to $1.82 \mathrm{~g} \mathrm{~cm}^{-3}$ ). The least 


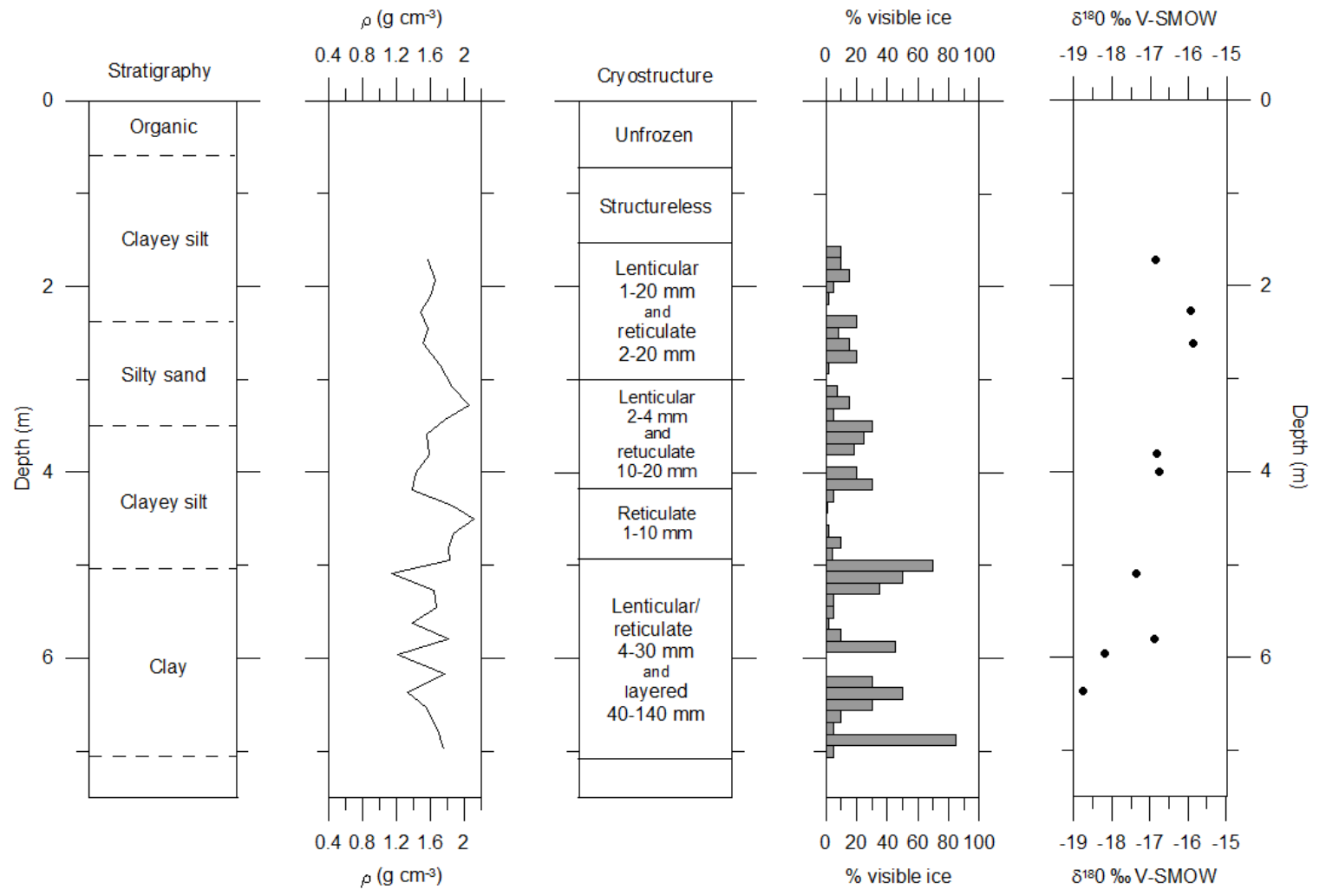

Figure 4.5: Stratigraphy, frozen bulk density ( $\rho)$, cryostructures, visible ice, and $\delta^{18} O$ values at BHO3 (side of feature, near the peak; approximately $3 \mathrm{~m}$ above the peatland). 
negative $\delta^{18} \mathrm{O}$ values were in the upper clayey silt layer $(-15.9 \%$ at $2.62 \mathrm{~m}$ was the least negative sample) and became more negative with depth (-18.8\%o at $6.36 \mathrm{~m}$ near the base of the borehole). The total ice thickness per $0.50 \mathrm{~m}$ depth and cumulative ice lens thickness with depth are presented in Table 4.2c.

\subsubsection{BH04 (a+b) surficial conditions}

Overall ecotype: birch forest (Figure 4.3c). Borehole BH04 was located at the top of the feature at BCSA, 14 m north of BH03 and $40 \mathrm{~m}$ south of Highway 3 (Figure 3.4). There were $<5^{\circ}$ slopes to the north and south. The thaw depth on 12 August, 2011, was $0.97 \mathrm{~m}$. Ground surface cracks and depressions 0.1 to $0.3 \mathrm{~m}$ deep were present. The ground surface was organic-rich and slightly damp. There was no visible disturbance at the site. Large ( $8 \mathrm{~m}$ in height) mature paper birch $(25 \%$ cover $)$ and two mature $(8 \mathrm{~m}$ in height) white spruce trees dominated the vegetation.

\subsubsection{BH04 (a+b) sub-surface conditions}

Figure 4.6 presents the stratigraphy, $\rho$, cryostructures, VI, and $\delta^{18} \mathrm{O}$ values for BH04 $(\mathrm{a}+\mathrm{b})$. BH04a was drilled in 2011 and terminated at $4.20 \mathrm{~m}$ due to a broken drill rod. BH04b continued to $8.40 \mathrm{~m}$ in an adjacent borehole drilled the following summer less than $1 \mathrm{~m}$ from $\mathrm{BH} 04 \mathrm{a}$.

Unfrozen silty organics extended to $0.30 \mathrm{~m}$. A thin layer of unfrozen silty sand occurred between 0.69 and $0.97 \mathrm{~m}$. The thaw depth was $0.97 \mathrm{~m}$. The ground was icepoor to $1.40 \mathrm{~m}$. Lenticular lenses $4 \mathrm{~mm}$ thick were found at a $30^{\circ}$ angle between 2.55 and $2.71 \mathrm{~m}$ in clayey silt. A second silty sand layer occurred between 3.20 and $3.60 \mathrm{~m}$, after which the sediment texture returned to clayey silt. Ice contents noticeably increased at 4.0 $\mathrm{m}$ to the borehole terminus. $20-50 \mathrm{~mm}$ lenticular structures were common at $4.0-5.0 \mathrm{~m}$. 


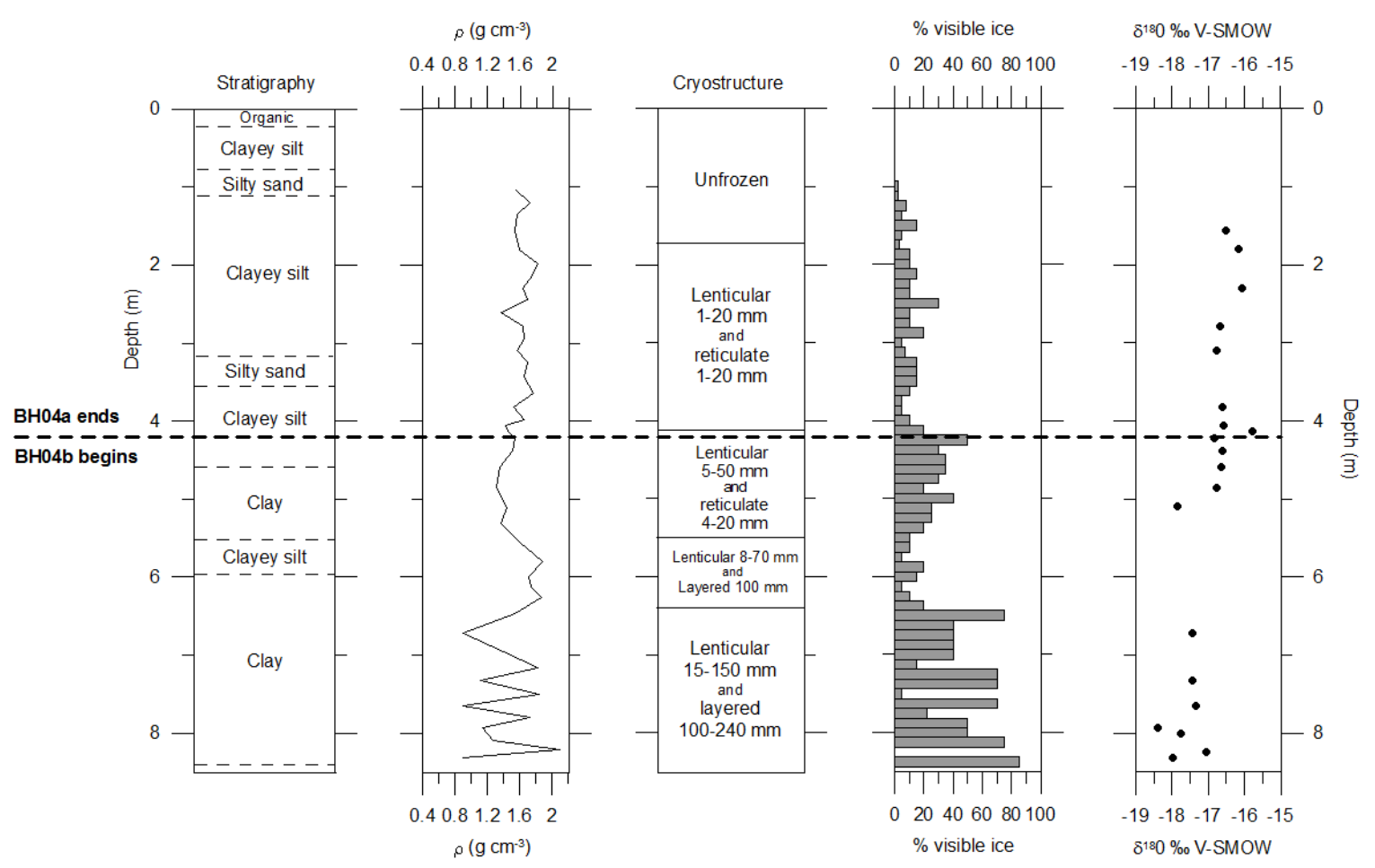

Figure 4.6: Stratigraphy, frozen bulk density ( $\rho)$, cryostructures, visible ice, and $\delta^{18} O$ values at $\mathrm{BHO} 4(\mathrm{a}+b)$ (top of feature; approximately $4 \mathrm{~m}$ above the surface of the peatland). 
Bulk density was low due to the large amount of ice present (approximately $1.38 \mathrm{~g} \mathrm{~cm}^{-3}$ ). The transition to the first clay layer occurred at $4.55 \mathrm{~m}$, and then clayey silt at $5.5 \mathrm{~m}$, to return to a deep-seated clay layer at $5.95 \mathrm{~m}$ depth.

In general, large horizontal ice structures $<240 \mathrm{~mm}$ thick were found within the clays to the borehole terminus. Bulk density varied widely with ice content. Near the base of the borehole, $\rho$ of less than $1 \mathrm{~g} \mathrm{~cm}^{-3}$ was recorded, coinciding with a pure ice cryostructure. Dense, stiff clay with a $\rho$ of $2.09 \mathrm{~g} \mathrm{~cm}^{-3}$ occurred directly above the ice (e.g., 7.41 to $7.58 \mathrm{~m}$; Figure 4.7a). Additional cores of pure ice were extracted at 7.60 to $7.70 \mathrm{~m}, 7.76$ to $8.0 \mathrm{~m}$, and 8.24 to $8.40 \mathrm{~m}$ depths (Figure $4.7 \mathrm{~b}$ ). The $\delta^{18} \mathrm{O}$ values in the upper $5 \mathrm{~m}$ ranged between -16.8 and $-15.8 \%$, whereas values were noticeably more negative in the deep-seated clays, ranging between -18.4 and $-17.1 \%$. Table $4.2 \mathrm{~d}$ presents total ice thickness per $0.5 \mathrm{~m}$ depth and cumulative ice thickness for BH04 (a+ b).

\subsubsection{BH05 surficial conditions}

Overall ecotype: mixed black spruce - birch forest (Figure 4.3d). Borehole BH05 was located off the main transect, but represents the northward slope of the feature (Figure 3.4). BH05 was located approximately $150 \mathrm{~m}$ west of BH04 $(\mathrm{a}+\mathrm{b})$ due to the nearby highway embankment and a transmission line close to the transect (Figure 3.5). The borehole was $20 \mathrm{~m}$ south of the road. The overall slope of the site was approximately $20^{\circ}$ descending toward the road. Thin, tall black spruce (30\% cover) $8 \mathrm{~m}$ in height dominated the tree species. Paper birch (10\% cover) $6 \mathrm{~m}$ in height and willows $(10 \%$ cover) $3 \mathrm{~m}$ in height were also present. 
a)

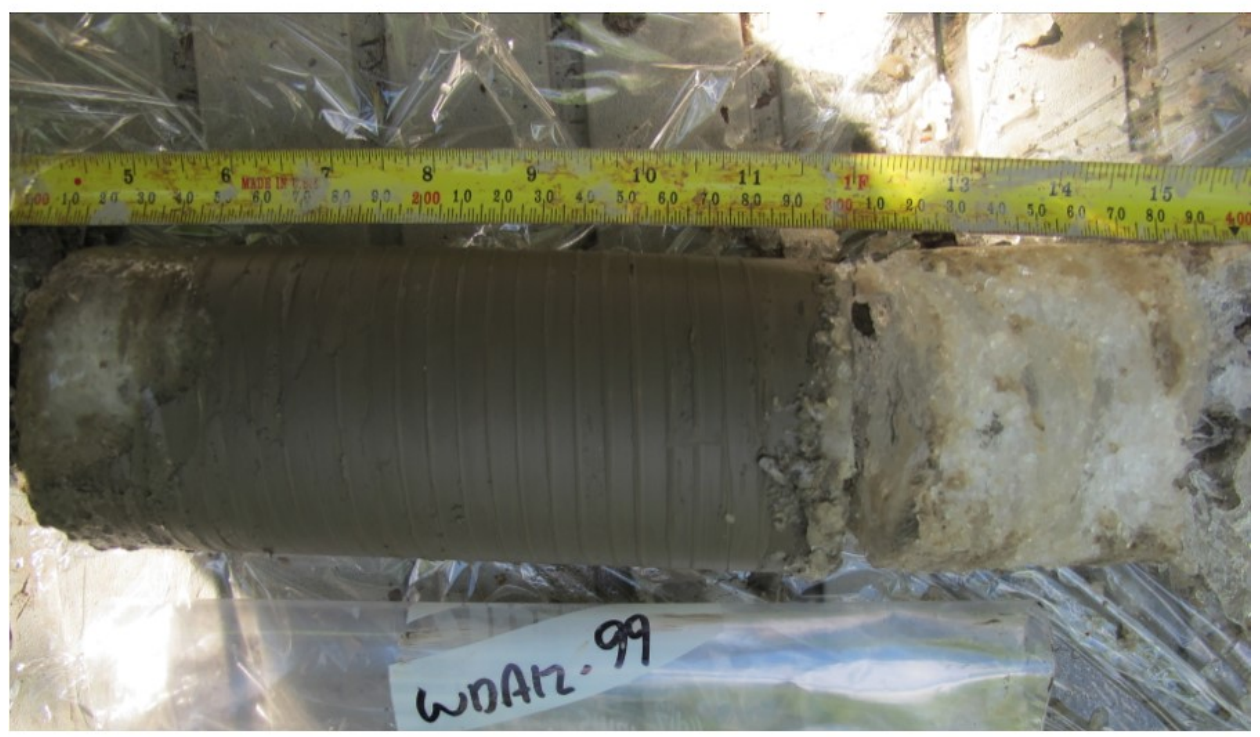

b)

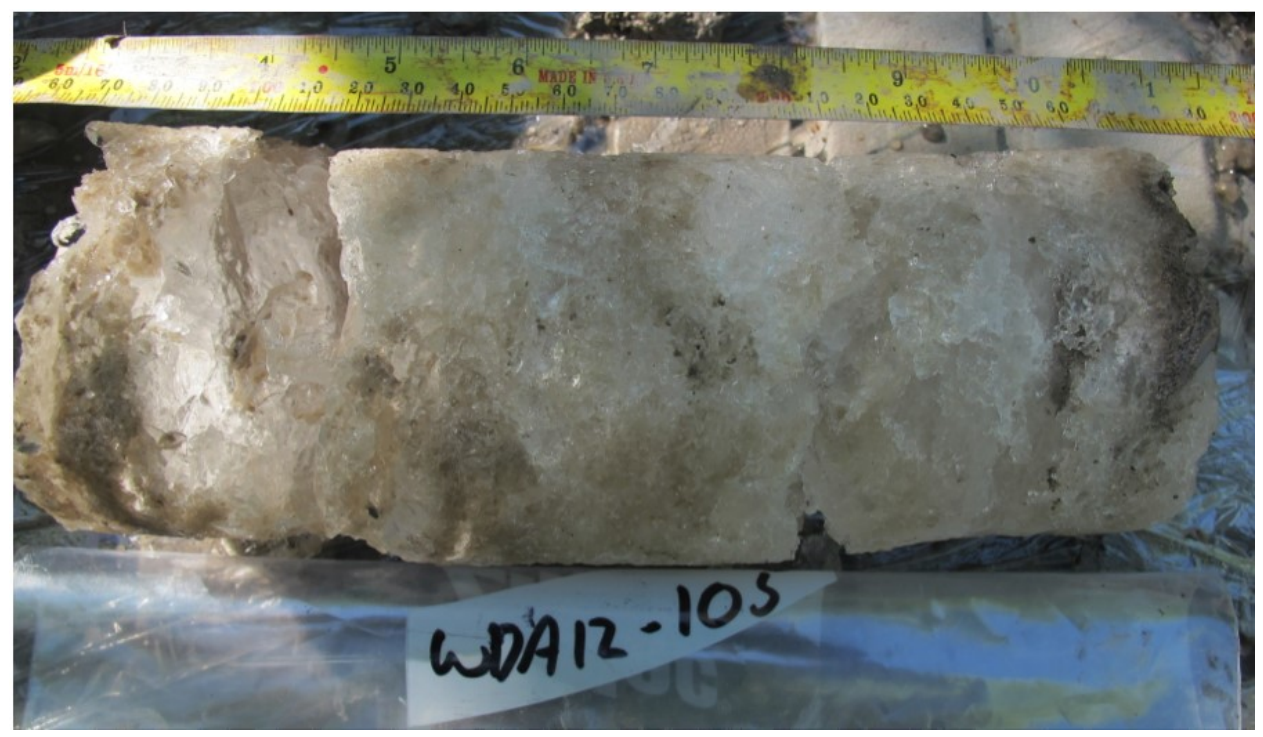

Figure 4.7: Core samples recovered from $\mathrm{BH} 04 \mathrm{~b}$ at a) 7.41-7.58 $\mathrm{m}$, demonstrating thick layers of sediment and ice; and b) 8.24-8.40 m, demonstrating pure ice at depth. 


\subsubsection{BH05 sub-surface conditions}

Figure 4.8 presents the stratigraphy, $\rho$, cryostructures, VI, and $\delta^{18} \mathrm{O}$ values at $\mathrm{BH} 05$, located on the north slope of the feature. The unfrozen organic layer was $0.20 \mathrm{~m}$ thick. Unfrozen clayey silt occurred to the thaw depth of $1.36 \mathrm{~m}$.

At $1.46 \mathrm{~m}$, there was distinctive $1 \mathrm{~mm}$-thick ice lens in clayey silt at a $30^{\circ}$ angle. Ice content increased with depth. At $1.61 \mathrm{~m}$, horizontal and sub-horizontal lenses 3 to 15 $\mathrm{mm}$ thick and continuous reticulate veins persisted to $1.98 \mathrm{~m}$. Bulk density ranged from 1.35 to $1.60 \mathrm{~g} \mathrm{~cm}^{-3}$, depending on ground ice content.

From 1.95 to $3.1 \mathrm{~m}$ depth, a silty sand layer was noted. The sediment was laminated, with light grey bands 1 to $2 \mathrm{~mm}$ thick at up to $60^{\circ}$ from horizontal. Tilted 5 $\mathrm{mm}$ thick ice lenses at 20 and $45^{\circ}$ appeared at continuous intervals and extended to 3.0 m. Sediment texture transitioned back to clayey silt at $3.1 \mathrm{~m}$ (Figure 4.8). Between 4.0 and $4.4 \mathrm{~m}$, circular and flattened bubbles appeared within a $25 \mathrm{~mm}$ ice lens and near iceclay contacts.

Ice-rich grey clay occurred from $5.5 \mathrm{~m}$ to the borehole terminus at $7.30 \mathrm{~m}$. Average $\rho$ decreased to $1.2 \mathrm{~g} \mathrm{~cm}^{-3}$ due to high ice contents. At $6.60 \mathrm{~m}$, ice was oriented at steep angles $\left(>50^{\circ}\right)$, and VI was estimated at $60 \%$. At $6.75 \mathrm{~m}$, the clay appeared highly plastic, unfrozen and moldable in the hand. This unfrozen clay was cold to touch and was suspended in ice. Layered ice was common, as lenses typically exceeded 100 $\mathrm{mm}$ in thickness. The final section of core extended to a depth of $7.30 \mathrm{~m}$ and was composed of one exceptional ice lens $210 \mathrm{~mm}$ thick. Bubbles were present at the top of this ice section and continued down the middle of the core. The variation of $\delta^{18} \mathrm{O}$ values in the upper $4 \mathrm{~m}$ was small (between -16.8 and $-16.3 \%$ ). The least negative value at 

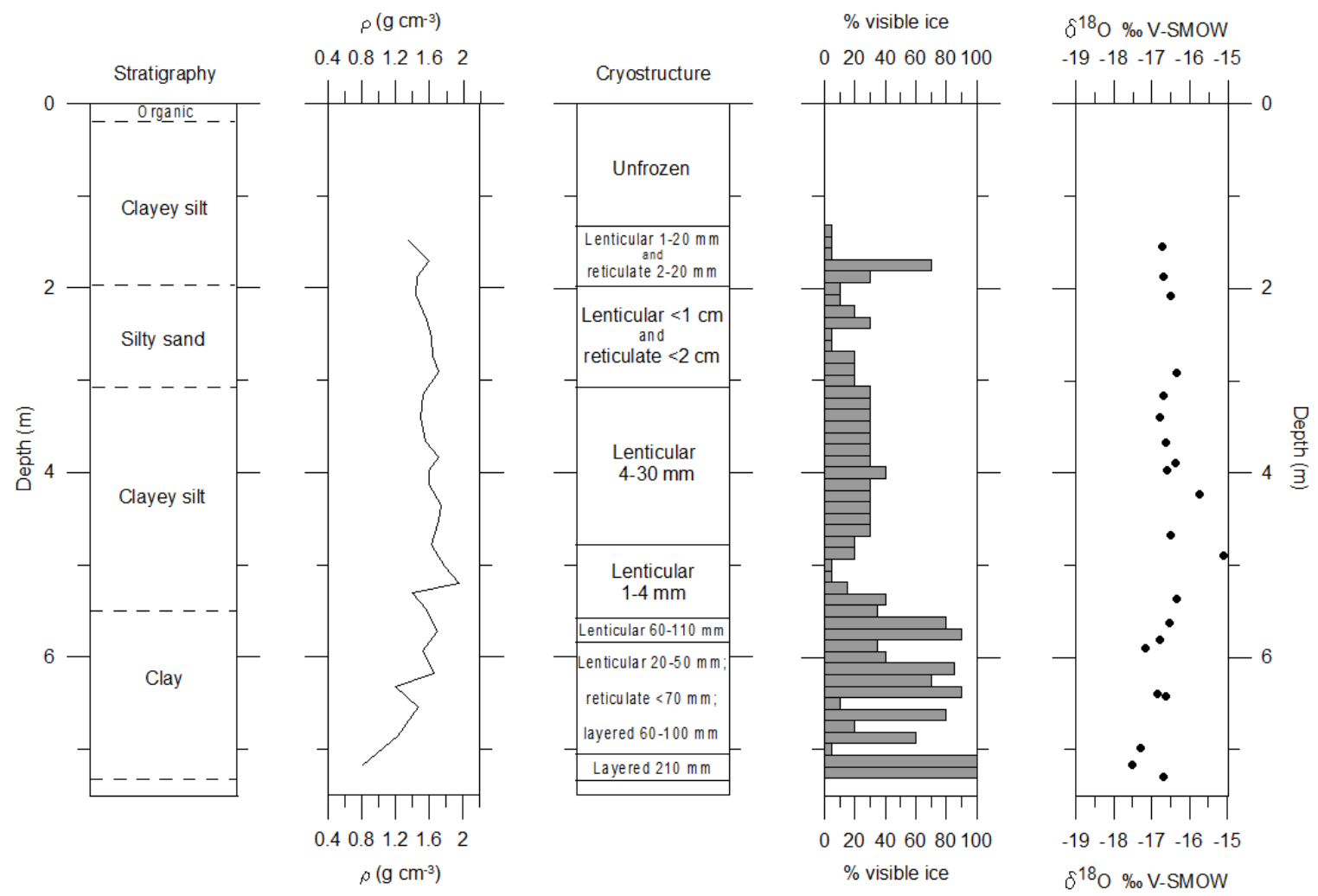

Figure 4.8: Stratigraphy, frozen bulk density ( $\rho)$, cryostructures, visible ice, and $\delta^{18} O$ values at BHO5 (side of feature on highway side; approximately the same elevation as BHO3). 
depth was recovered at $4.9 \mathrm{~m}(-15.1 \%)$, and values decreased slightly in the ice-rich clays. The most negative $\delta^{18} \mathrm{O}$ value was $-17.5 \%$ at $7.17 \mathrm{~m}$. Table $4.2 \mathrm{e}$ presents total ice thickness per $0.50 \mathrm{~m}$ increment and cumulative ice thickness in BH05.

\subsubsection{Supplemental data}

Two shallow boreholes, $\mathrm{BH} 12$ and $\mathrm{BH} 13$, were also drilled to assist with stratigraphic interpretation and to collect samples for radiocarbon dating. The sub-surface results of $\mathrm{BH} 12$ and $\mathrm{BH} 13$ are presented in Figure 4.9a, b. In general, the depth to the top of the silty sand layer was consistent with the other deep boreholes drilled in the feature.

\subsection{Elevations}

LiDAR-derived surface elevation (Figure 3.4) indicates the lowest point of BCSA, located at the northern toe of the feature, at approximately $166.1 \mathrm{~m}$ a.s.1. The peatland surface is approximately $0.3 \mathrm{~m}$ higher than the lowest point. Borehole BH04 is located at the highest point of the frost mound, $3.7 \mathrm{~m}$ above the toe (Figure 3.4).

\subsection{Water jet drilling to bedrock}

A bedrock outcrop was present at the south end of the transect at BCSA (Figure 3.1). The depth to bedrock in the peatland at BCSA was approximately $9 \mathrm{~m}$, as determined by water jet drilling. Another water jet borehole on top of the feature approximately $3.7 \mathrm{~m}$ above the peatland indicated that the depth to bedrock was more than $10.3 \mathrm{~m}$ from the mound's surface. This borehole did not encounter bedrock, and 
a)
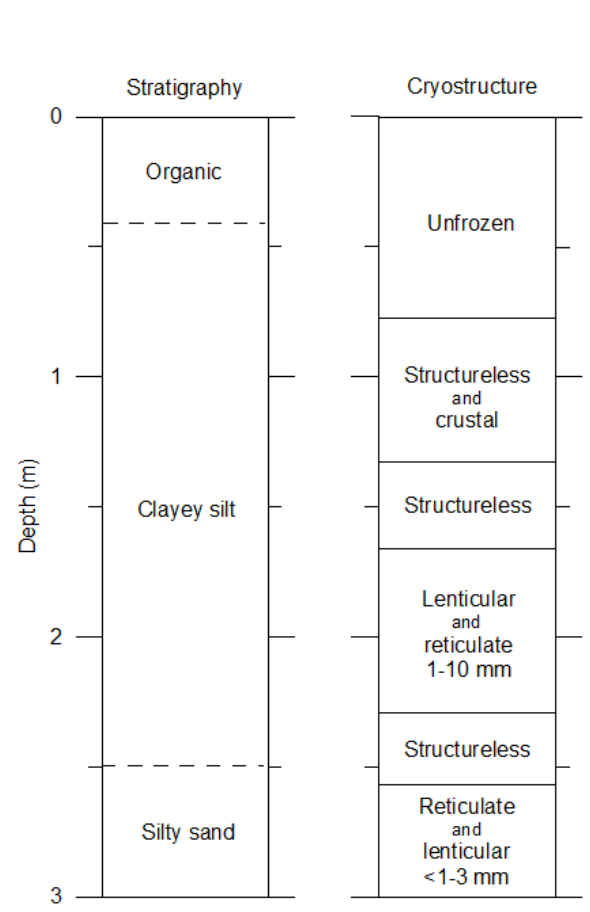

$\%$ visible ice

020406080100

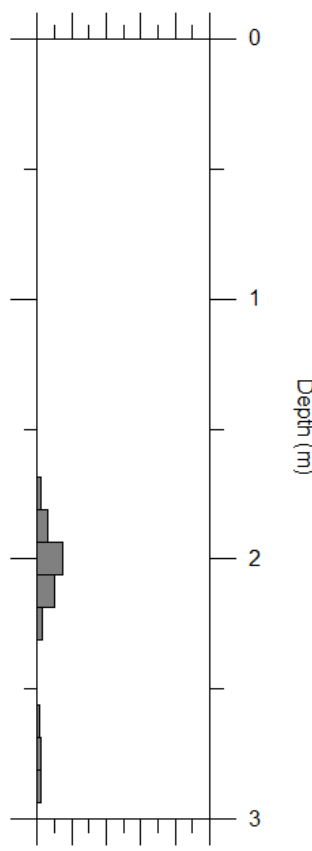

020406080100

$\%$ visible ice

b)
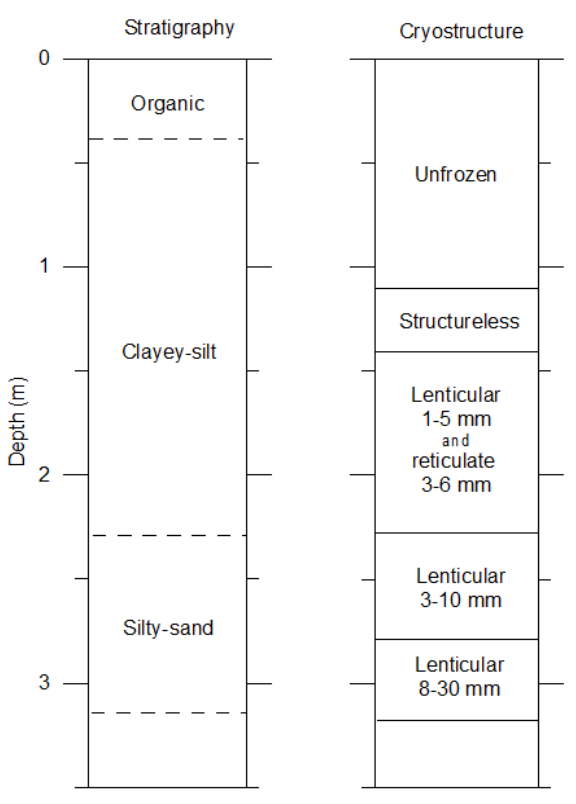

$\%$ visible ice

020406080100

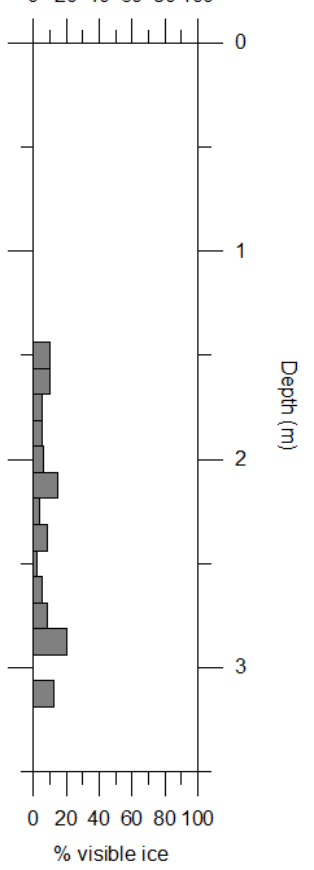

Figure 4.9: Stratigraphy, cryostructures and visible ice from a) BH12 and b) BH13. Bulk densities were not calculated. Note: the scale of this diagram is larger than previous borehole diagrams. 
there was no discernable change in sediment stratigraphy throughout the drilling process. The sediment was clayey and became more ice rich with depth.

\subsection{Ground ice content}

Ground ice at depth within the feature may explain its raised height relative to the surrounding topography. The cumulative thicknesses of ice, as described in Table 4.2, were plotted against the total height of the feature based on the top of the first sediment layer (Figure 4.10). The overlying organic layers at each borehole were not included in order to compare a constant stratigraphic surface. The top of the mineral layer beneath the peat at BH01 was used as the base of the feature height, and is referred to as the 'sediment reference height', located at $165.5 \mathrm{~m}$ a.s.1. Delineated ground ice may account for approximately $54 \%$ of the variation in feature height at its peak (BH04 a+b).

\subsection{Summary of stratigraphy}

\subsubsection{Organic deposits}

Organic layers on the transect did not contain peat and were generally composed of dead grasses and leaves. Much of the ground surface was bare or covered with deadfall. A thin $0.20 \mathrm{~m}$ peat layer was present at $\mathrm{BH} 05$, located $150 \mathrm{~m}$ off the transect. Within the boreholes on the feature, organic layers ranged in thickness from 0.20-0.50 $\mathrm{m}$. In general, these layers were dry near the surface, and became moister with depth.

\subsubsection{The sediment}

The sediments found at BCSA may be divided into three distinct groups: clays, clayey silts, and silty sands, based on Shepard's (1954) ternary diagram (Figure 4.11a). The distinct layers are presented from the lowest unit upward. 


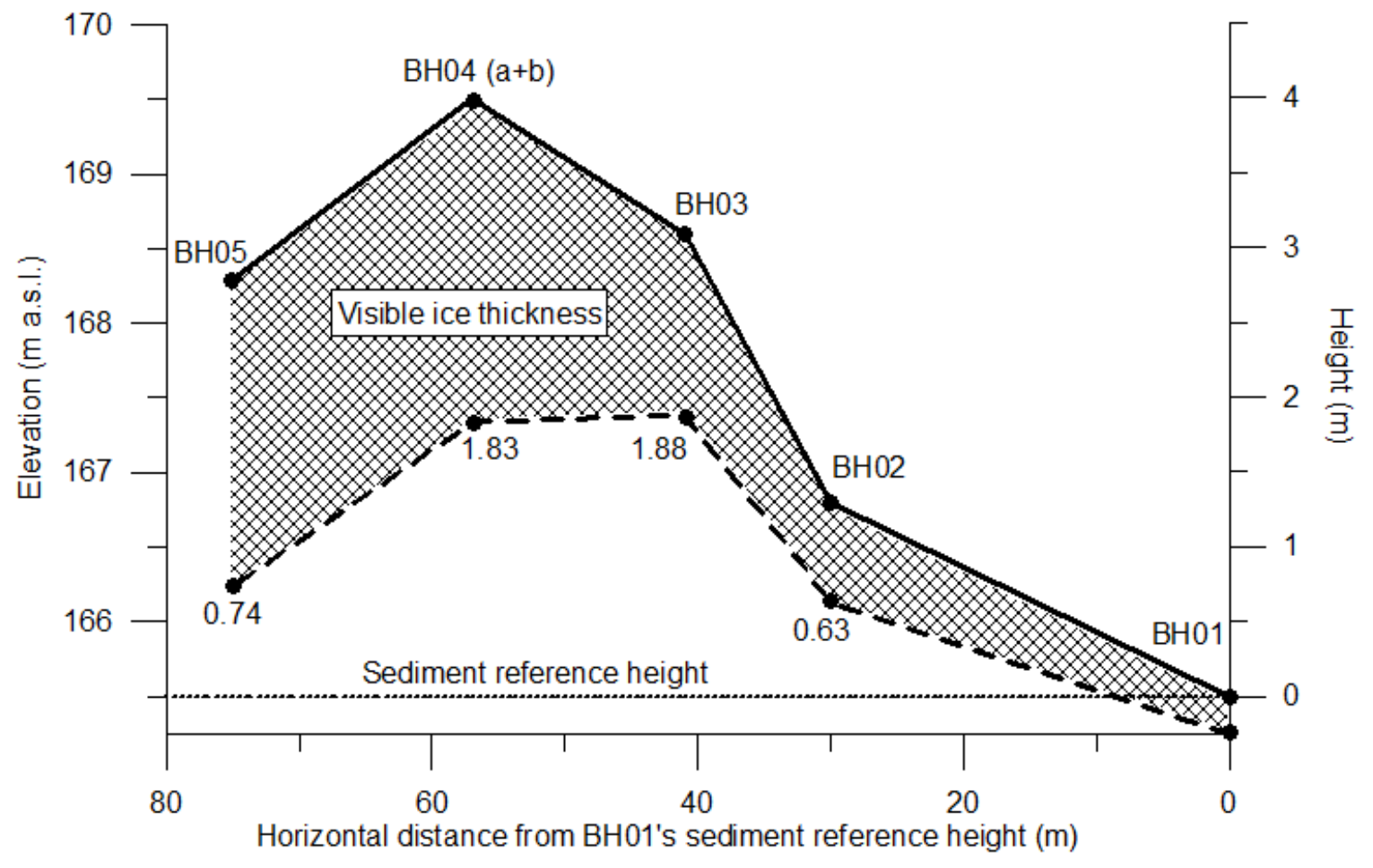

Figure 4.10: Borehole elevation (with organic cover removed), and distance from BH01, with thickness of visible ice in each borehole. The reference height is the top of mineral sediment at BHO1. 
a)

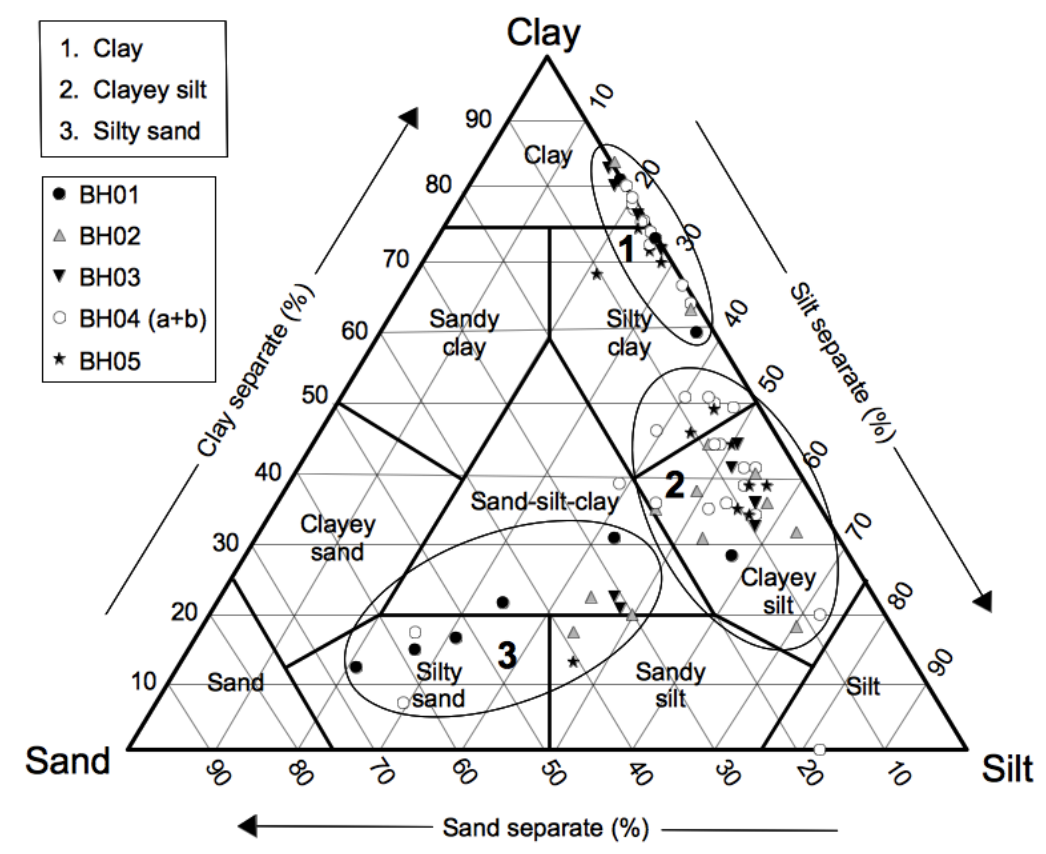

b)

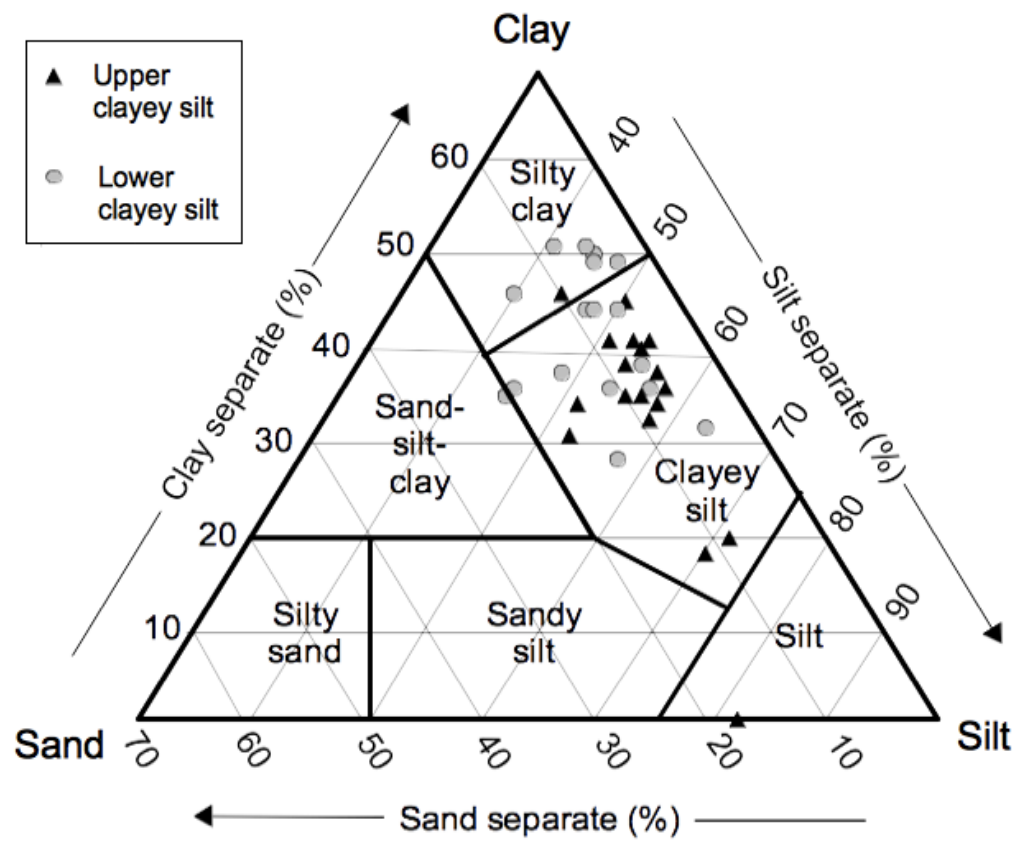

Figure 4.11: Ternary diagrams derived from Shepard (1954) displaying a) all grain size samples recovered from boreholes BH01-05 at the BCSA site; and b) all samples classified as clayey silt, and categorized into upper clayey silts, and lower clayey silts. The lower clayey silts occurred below the silty sand stratigraphic layer at BCSA. 


\subsubsection{Clays}

According to Shepard's (1954) ternary diagram (Figure 4.11a), clays are sediments containing more than $75 \%$ of particles smaller than $0.004 \mathrm{~mm}$. For the purposes of this thesis, Shepard's (1954) classification of clays is expanded to include sediment samples on the ternary diagram that were also silty clays with a high clay fraction. At BCSA, sediments classified as 'clays' contain 58 to $83 \%$ clay particles, with a nominal (0-2\%) sand component.

Dense clay appeared both under the feature and the peatland between 4 and $8.4 \mathrm{~m}$ depths, and was the lowest stratigraphic unit in each deep borehole (Figure 4.12). These clays were grey, dense, stiff and homogenous. Sampled frozen bulk densities were highly variable in these sediments as stiff clays were frequently layered between thick ice lenses.

\subsubsection{Lower clayey silts}

Clayey silts were the most common sediment type recovered during drilling at BCSA. Silt particle sizes were between 0.004 and $0.063 \mathrm{~mm}$, and using Shepard's (1954) ternary diagram (Figure 4.11a), clayey silts were categorized as sediments containing 40 $\%$ or more silt and $50 \%$ or less clay. Clayey silts appeared as two distinct layers in the stratigraphic profile, referred to here as upper and lower layers (Figures 4.11b, 4.12).

A layer of lower clayey silts was observed above the basal clay in all of the boreholes (Figure 4.12). These sediments commonly contained excess ice increasing in quantity with depth. The grain-size distribution of the clayey silts in this lower layer overlapped considerably with upper clayey silts (Figure 4.11b). Upper clayey silts were generally tightly grouped, falling mostly within Shepard's (1954) clayey silt category, 


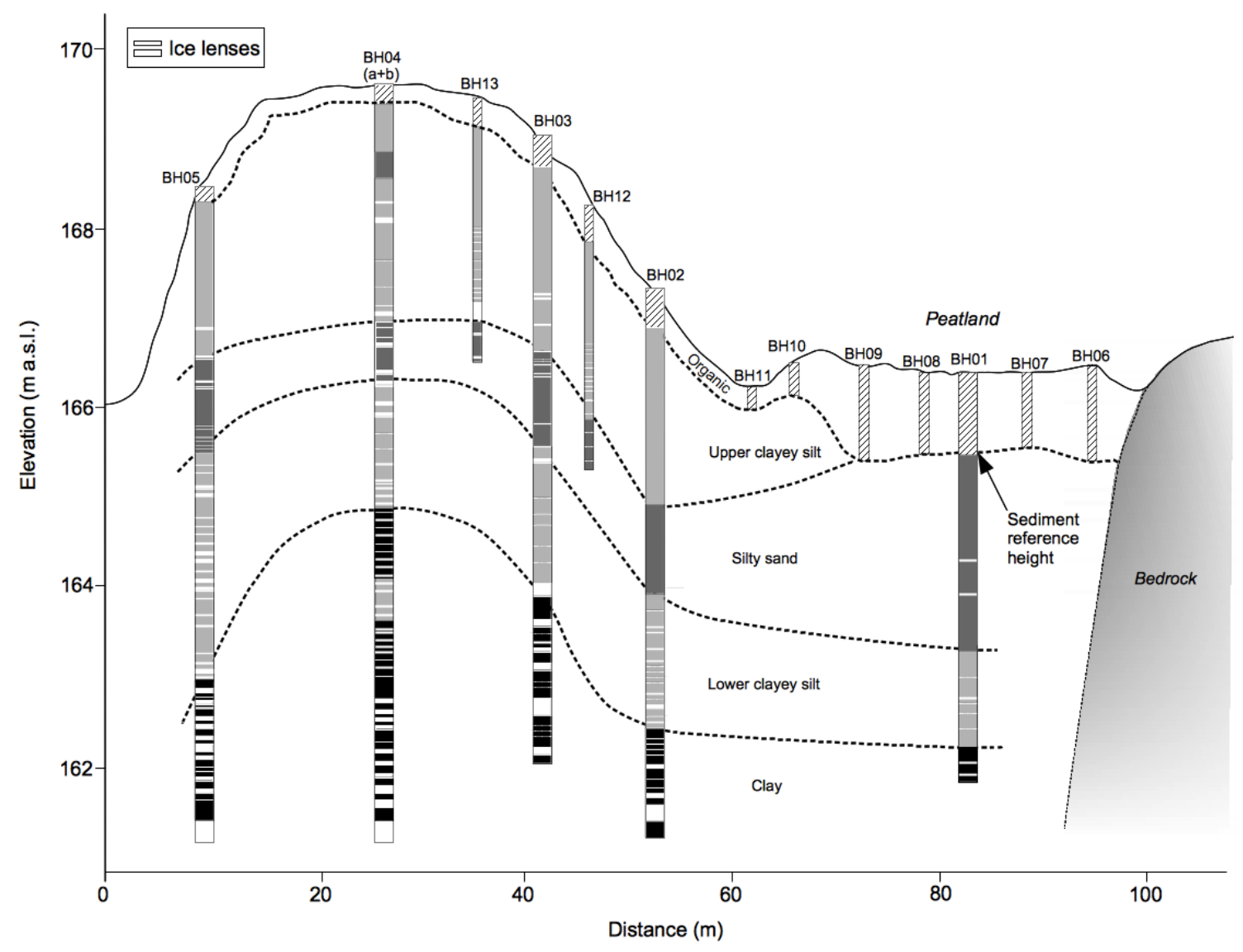

Figure 4.12: A cross-sectional profile of BCSA along the transect, displaying the all boreholes with 4 stratigraphic units, ground ice thicknesses, and implied connections between layers at depth. Ice lenses in boreholes are depicted in white. 
whereas some of the clayey silts at depth contained a higher clay fraction and thus extended into Shepard's (1954) silty clay classification.

\subsubsection{Silty sand}

Each deep borehole at BCSA contained at least one layer of silty sand situated between the upper and lower layers of clayey silt (Figure 4.12). The grain-size range for sand is 0.063 to $2 \mathrm{~mm}$. Most of the silty sands within the feature also contained a large portion of silt (Figure 4.11a). The thicknesses of the silty sand layers in the feature were between 0.5 to $1.2 \mathrm{~m}$ (Figure 4.12). The silty sand layer thickness under the peatland was more than twice that of layers within the feature.

The silty sand layer was encountered at a similar depth in each of the boreholes on the feature, between 2 and $4 \mathrm{~m}$, except for BH04 that had two smaller silty sand layers situated at 1 and $3.5 \mathrm{~m}$ (Figure 4.12). One layer classified as strictly sand at $1 \mathrm{~m}$ depth was delineated by a single sample and was layered between much finer clayey silt. The second silty sand layer in $\mathrm{BH} 04$ was present between 3 and $4 \mathrm{~m}$ depth, consistent with the position of the silty sand layer of the other boreholes (Figure 4.12).

\subsubsection{Upper clayey silts}

Within the feature, the upper layer of clayey silts was located beneath the organic material. The material often had a brownish colour within the first metre, and then transitioned to a grey colour. This transition occurred at $1.23 \mathrm{~m}$ for BH02, $1.61 \mathrm{~m}$ for $\mathrm{BH} 03,1.30 \mathrm{~m}$ for BH04a, and $1.46 \mathrm{~m}$ for BH05. Grain-size analysis indicated only small differences in texture between the two differently coloured sediments. For example, at BH03, a sample of brown clayey silt at $1.13 \mathrm{~m}$ had a sand-silt-clay ratio of 5-50-45 \% whereas in the grey clayey silt at $1.93 \mathrm{~m}$, the ratio was $8-51-41 \%$. 


\subsection{Unfrozen water content}

As described in Section 2.1.3, clays have high unfrozen water contents due to their large specific surface area (SSA) and adsorbed water. Measuring SSA to calculate unfrozen water content was not feasible for this thesis. Therefore data from BCSA were compared with the literature.

The temperature profile at BCSA (Figure 3.2) indicates that the average temperature between 4.3 and $9.3 \mathrm{~m}$ depth in the feature is $-0.93^{\circ} \mathrm{C}$. The unfrozen water contents of typical silt and clay fractions at $-1{ }^{\circ} \mathrm{C}$ are approximately 3 and $12 \%$ by volume (Osterkamp and Burn, 2003). Thus, the clayey silts and clays in the feature likely contained unfrozen water contents of approximately $12 \%$ due to the high clay contents of sediments from 4-8 $\mathrm{m}$ depth. The unfrozen water content in the clay may allow water movement toward the freezing front, which enables the formation of segregated ice lenses (Osterkamp and Burn 2003).

As mentioned in Section 4.1.3.8, unfrozen clay in a suspended cryostructure was noted at a depth of $6.75 \mathrm{~m}$ in BH05. Nearby ground temperature data presented in Section 3.1.5 indicate that the temperature at $6.75 \mathrm{~m}$ depth is approximately $-0.9^{\circ} \mathrm{C}$ year-round. The unfrozen water content in these deep sediments would facilitate water movement at depth well above the base of permafrost, as well as the possible growth of large ice lenses.

\subsection{Stable isotopes}

Stable isotope analyses provide evidence of the origin of water inside the feature. The data presented in Appendices $\mathrm{C}$ and $\mathrm{D}$ present the results for $\delta^{18} \mathrm{O}$ and $\delta^{2} \mathrm{H}$ determinations on samples from boreholes $\mathrm{BH} 01$ to $\mathrm{BH} 05$. Appendix E presents a plot of 
$\delta^{18} \mathrm{O}$ values for $\mathrm{BH} 01$ to $\mathrm{BH} 05$ in relation to borehole depth. Appendix F presents both $\delta^{18} \mathrm{O}$ and $\delta^{2} \mathrm{H}$ values of local water sources in the BCSA and Yellowknife area, and these data are plotted in Figure 4.13.

The $\delta^{18} \mathrm{O}$ values of waters and ice lenses recovered within the boreholes in both the peatland and the feature were more negative by $1-7 \%$ than local summer water sources (Figure 4.13). A one-sample one-tailed t-test determined that the $\delta^{18} \mathrm{O}$ value of local summer rainwater collected in Yellowknife (-14.8 \% V-SMOW) is statistically significantly greater than the mean $\delta^{18} \mathrm{O}$ value of BH04 $(\mathrm{a}+\mathrm{b})(\mathrm{p}<0.001)$.

The $\delta^{18} \mathrm{O}$ values within the deep-seated clays appear more negative than $\delta^{18} \mathrm{O}$ values in the near surface. To quantify this, Figure 4.6 indicates $\delta^{18} \mathrm{O}$ values with depth at BH04 $(\mathrm{a}+\mathrm{b})$ at the top of the feature. The $\delta^{18} \mathrm{O}$ values above the top of the first clay layer (between 1.57 and $4.59 \mathrm{~m}$ depth) were statistically significantly different than values within the clays and deeper clayey silts between 4.86 and $8.32 \mathrm{~m}(\mathrm{p}<0.001)$, determined with a Wilcoxon rank-sum test. Small variations of enrichment and depletion at depth also occur in BH04 on the order of 1-2\%.

Figure 4.2 indicates $\delta^{18} \mathrm{O}$ values with depth at $\mathrm{BH} 01$ in the peatland. $\delta^{18} \mathrm{O}$ values from sediments below the peatland and the deep borehole in the feature closest to the peatland (BH02, Figure 4.4) differ by up to $2 \%$. A Wilcoxon rank-sum test indicated a statistically significant difference between the $\delta^{18} \mathrm{O}$ values recovered in the peatland borehole at BCSA $(\mathrm{BH} 01)$ and those recovered within the feature at $\mathrm{BH} 02(\mathrm{p}=0.017)$. There was no statistically significant difference between $\delta^{18} \mathrm{O}$ values from samples collected from the feature in $\mathrm{BH} 02$ and $\mathrm{BH} 04$ at depths between 1.50 and $5.0 \mathrm{~m}$ of substrate $(\mathrm{p}=0.691)$. 


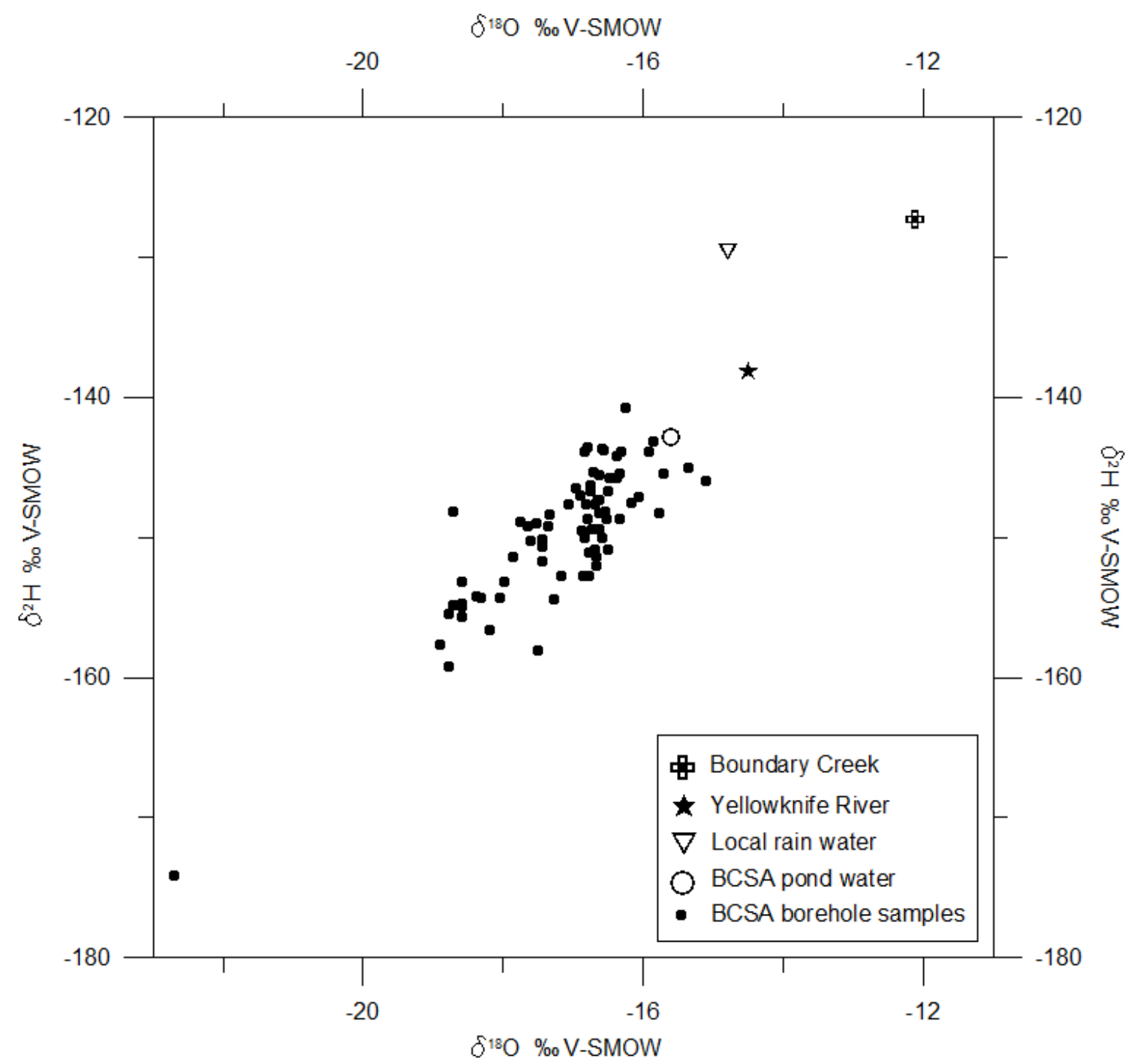

Figure 4.13 Co-isotope plot for samples collected at BCSA, Boundary Creek, and Yellowknife River. BCSA borehole samples $=3.80 x-84.61$. 


\subsection{Geochemistry}

Tables of all geochemical samples and plotted results from all boreholes are presented in Appendices $\mathrm{G}$ and $\mathrm{H}$. The concentration of ions co-varied with depth in the borehole profile, a trend prevalent throughout boreholes BH01 to BH05 (Appendix I). To quantify these apparent trends, inter-ion Spearman rank correlation coefficients $\left(\mathrm{r}_{\mathrm{s}}\right)$ were determined for samples from BH04 (Table 4.3, Appendix J). The $\mathrm{Ca}^{2+}$ concentration levels at BH04 were significantly related to $\mathrm{SO}_{4}{ }^{2-}\left(\mathrm{r}_{\mathrm{s}}=0.98 ; \mathrm{p}<0.001\right), \mathrm{Mg}^{2+}\left(\mathrm{r}_{\mathrm{s}}=0.93\right.$; $\mathrm{p}<0.001)$, and $\mathrm{K}^{+}\left(\mathrm{r}_{\mathrm{s}}=0.68 ; \mathrm{p}<0.001\right)$, whereas $\mathrm{Cl}^{-}$was significantly and highly correlated with $\mathrm{Na}^{+}\left(\mathrm{r}_{\mathrm{s}}=0.75 ; \mathrm{p}<0.001\right)$. The $\mathrm{Ca}^{2+}$ ion can therefore represent concentration levels of $\mathrm{Mg}^{2+}, \mathrm{K}^{+}$and $\mathrm{SO}_{4}{ }^{2-}$ throughout the stratigraphic profile at $\mathrm{BH} 04$, whereas $\mathrm{Cl}^{-}$can represent levels of $\mathrm{Na}^{+}$(Figure 4.14).

The $\mathrm{Ca}^{2+}$ concentrations appeared to generally follow borehole stratigraphy. Concentrations were high near the surface at $\mathrm{BH} 04$, with a maximum concentration level of $13.0 \mathrm{mEq} / \mathrm{L}$ at $0.3 \mathrm{~m}$ depth just below the unfrozen organic layer (Figure 4.14). Below the thaw depth, in the first silty sand layer, $\mathrm{Ca}^{2+}$ concentrations declined, then increased at the silty sand - clayey silt interface at $1.30 \mathrm{~m}$. The $\mathrm{Ca}^{2+}$ then sharply declined throughout the clayey silt layer, and then increased once again approaching the second silty sand layer. The borehole stratigraphy subsequently became clay rich, and $\mathrm{Ca}^{2+}$ concentrations consistently decreased with depth to the borehole terminus, with variations of 2-3 $\mathrm{mEq} / \mathrm{L}$ between samples.

Chloride concentrations did not follow the same trend as $\mathrm{Ca}^{2+}$ throughout the sediment profile. Four distinct directional trends occurred. First, maximum $\mathrm{Cl}^{-}$ concentrations were within the unfrozen organic layer $(1.05 \mathrm{mEq} / \mathrm{L}$ at $0.13 \mathrm{~m}$ depth 
Table 4.3: Spearman correlation coefficients $\left(r_{s}\right)$ for geochemistry samples from BHO4 $(a+b)$. Table also indicates significance $(p \leq 0.05)$.

\begin{tabular}{|c|c|c|c|c|c|c|}
\hline Ion & Calcium & Chloride & Magnesium & Potassium & Sodium & Sulphate \\
\hline Calcium & 1 & 0.18 & $0.93^{*}$ & $0.68^{*}$ & $0.32^{*}$ & $0.98^{*}$ \\
\hline Chloride & NA & 1 & -0.06 & $-0.39^{*}$ & $0.75^{*}$ & 0.13 \\
\hline Magnesium & NA & NA & 1 & $0.8^{*}$ & 0.09 & $0.95^{*}$ \\
\hline Potassium & NA & NA & NA & 1 & -0.13 & $0.69^{*}$ \\
\hline Sodium & NA & NA & NA & NA & 1 & 0.27 \\
\hline Sulphate & NA & NA & NA & NA & NA & 1 \\
\hline
\end{tabular}

* Indicates significant relationship 
$\mathrm{Cl} \cdot(\mathrm{mEq} / \mathrm{L})$

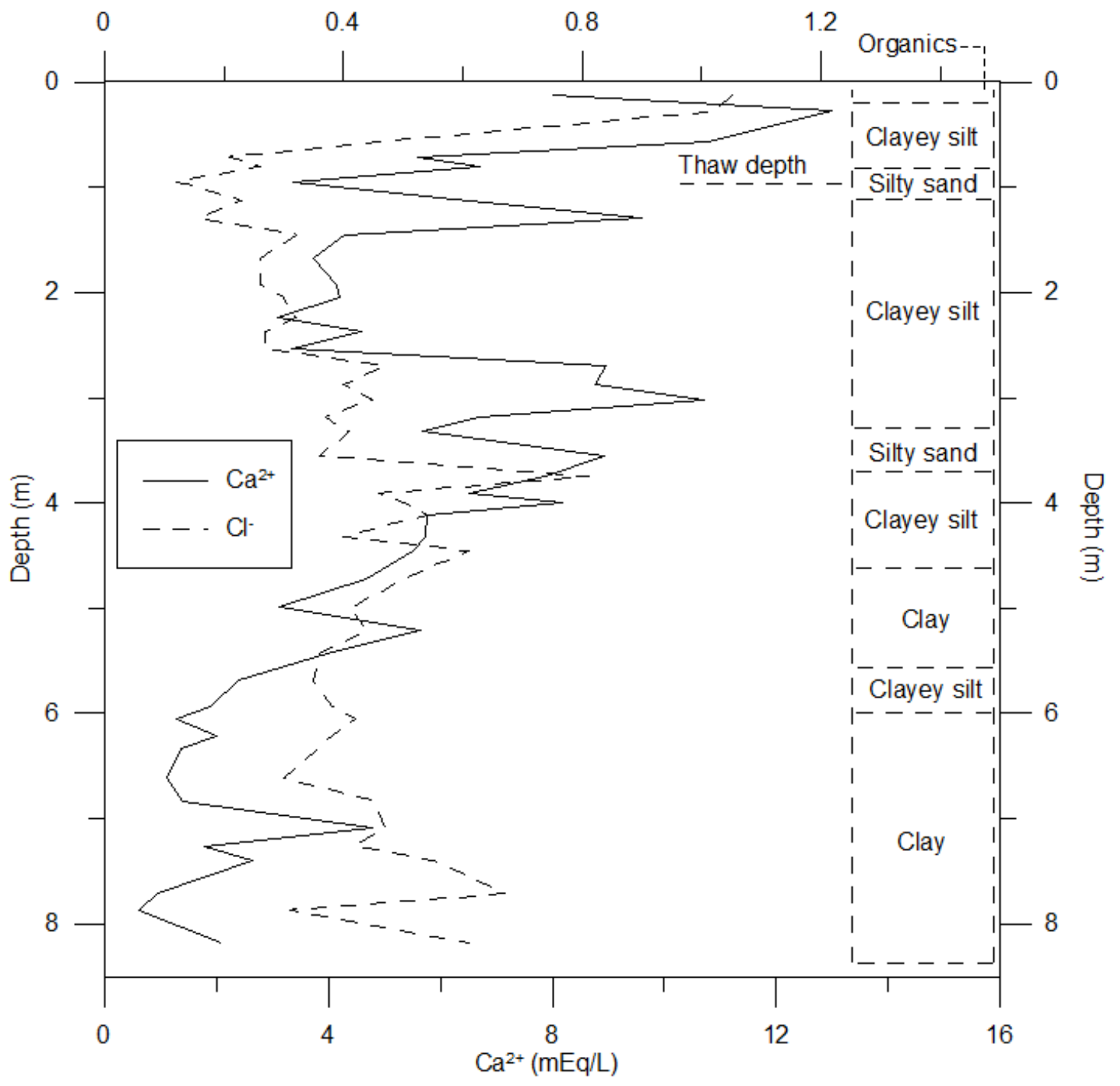

Figure 4.14: $\mathrm{Ca}^{2+}$ and $\mathrm{Cl}^{-}$concentrations with depth at BHO4 (a+b) (top of the feature). Sediment stratigraphy is also presented. 
(Figure 4.14)) and levels sharply declined to the thaw depth. Second, $\mathrm{Cl}^{-}$levels gradually increased to just over $0.4 \mathrm{mEq} / \mathrm{L}$ throughout the near-surface silty sand and clayey silt layers to $3.5 \mathrm{~m}$ then sharply increased at $3.75 \mathrm{~m}$ depth. Third, $\mathrm{Cl}^{-}$levels generally decreased throughout the alternating clayey silt and clay layers of the profile to 0.3 $\mathrm{mEq} / \mathrm{L}$ at $6.61 \mathrm{~m}$. Fourth, overall $\mathrm{Cl}^{-}$levels increased while sharp variances occurred through the bottommost clay section of the stratigraphy between 6.6 and $8.4 \mathrm{~m}$.

$\mathrm{Cl}^{-}$concentrations often passed through alternating layers of clayey silt and clay without a major change in directional trend, indicating that the stratigraphy was not the main driver for $\mathrm{Cl}^{-}$(and by extension, $\mathrm{Na}^{+}$) concentrations.

\subsection{Timing}

Eight organic samples were taken from boreholes at BCSA for AMS radiocarbon analysis (5 of which are illustrated in Figure 4.15) to establish a timeline of feature formation and to understand the geomorphic changes that have occurred at BCSA. Radiocarbon results are reported in Table 4.4.

A sample taken from the base of the peat at $0.62 \mathrm{~m}$ from $\mathrm{BH} 01$ returned an age of 1270 to 1070 cal BP (Figure 4.15) indicating terrestrial emergence and organic accumulation. Detrital organics were found in mineral sediments below the peatland and within the feature. Burned wood was recovered from the silty sand in BH01 at 2.20 and $2.55 \mathrm{~m}$ (Figure 4.15), dated to 1770-1610 and 1510-1420 cal BP. A date reversal occurs in the BH01 samples, so it is likely that these burned wood samples were transported to BCSA from another location before deposition. A charcoal sample was recovered in BH12 at approximately $1.9 \mathrm{~m}$ depth (Figure 4.15), which returned the oldest date at the study site of 3460 to 3360 cal BP. A detrital organic sample was recovered in BH04 at 


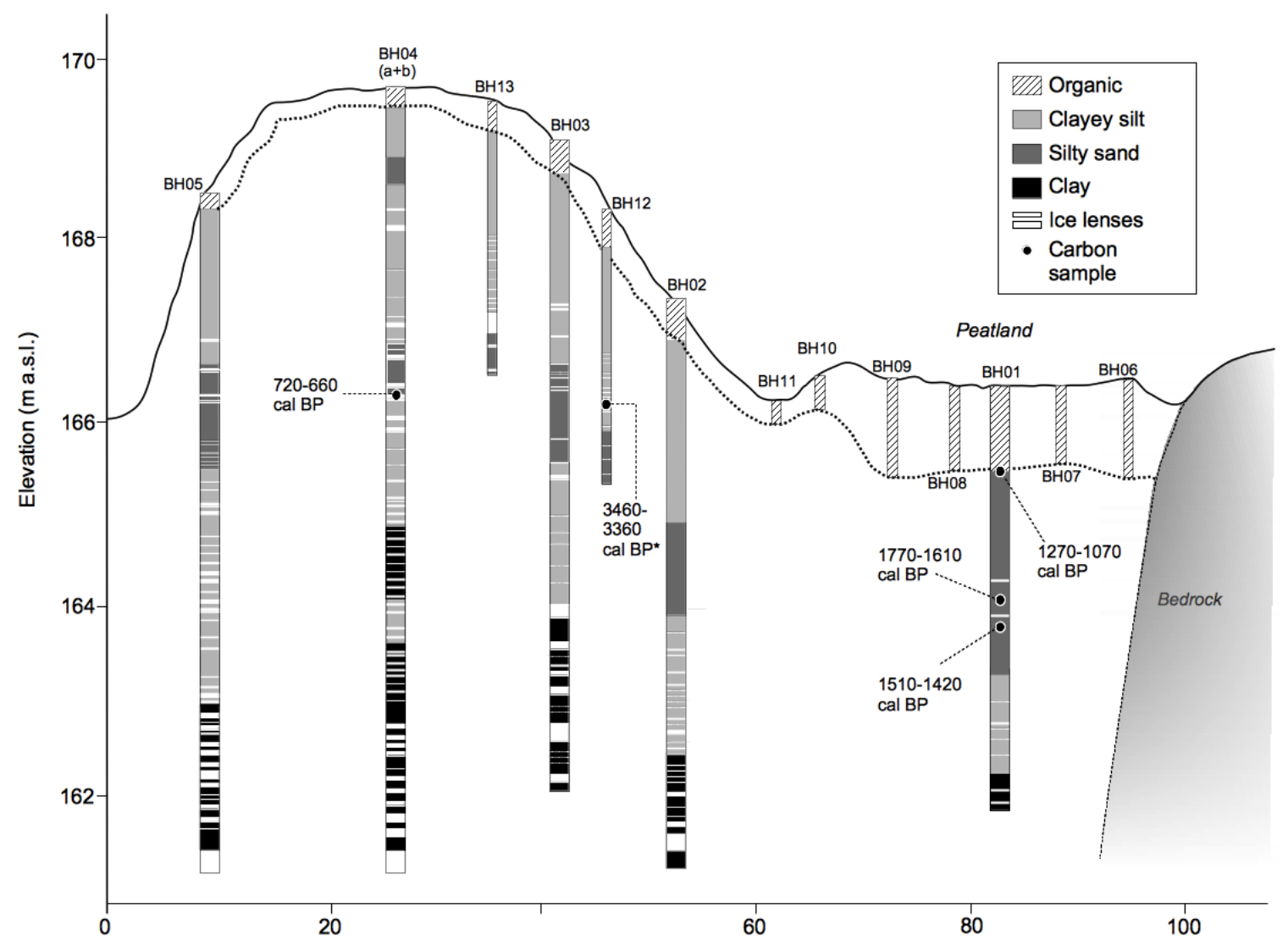

Figure 4.15: Cross-sectional profile of the transect at BCSA depicting AMS radiocarbon dates for samples recovered within the boreholes. Note: Date marked with a $*$ is not used in temporal interpretation. 
Table 4.4: AMS radiocarbon dates (conventional and calibrated to a standard deviation of $2 \sigma)$ for all organic samples at BCSA.

\begin{tabular}{|c|c|c|c|c|c|}
\hline $\begin{array}{c}\text { Beta Analytic } \\
\text { lab number }\end{array}$ & Borehole & $\begin{array}{c}\text { Depth } \\
(\mathbf{m})\end{array}$ & Sample type & $\begin{array}{c}\text { Date } \\
\text { (conventional) }\end{array}$ & Date (cal BP) \\
\hline 309321 & BH01 & 0.93 & Basal peat & $1240+/-30$ & $1270-1070$ \\
317798 & BH01 & 2.20 & Burned wood & $1770+/-30$ & $1770-1610$ \\
317799 & BH01 & 2.55 & Burned wood & $1570+/-30$ & $1510-1420$ \\
331114 & BH04 & 3.50 & Detrital organic & $740+/-30$ & $720-660$ \\
331113 & BH12 & 1.90 & Charcoal & $3190+/-30$ & $3460-3360$ \\
328917 & DP1 & 0.33 & Wood in basal peat & $210+/-30$ & 280 -post 1950 \\
328119 & DP5 & 0.55 & Wood in basal peat & $150+/-30$ & 280 -post 1950 \\
328918 & DP5 & 0.80 & $\begin{array}{c}\text { Plant material in } \\
\text { sediment }\end{array}$ & $300+/-30$ & $460-300$ \\
\hline
\end{tabular}


$3.5 \mathrm{~m}$ depth within silty sand and returned an AMS age of 720 to 660 cal BP, representing the youngest date on the BCSA transect.

Five small pockets of peat were identified between 200 and $400 \mathrm{~m}$ west of the transect. These pockets were located in depressions on top of the feature. Two of these pockets, labeled DP1 and DP5, located approximately $200 \mathrm{~m}$ apart, were cored to obtain organic material for dating. Wood was found at DP1 at a depth of $0.33 \mathrm{~m}$ at the basal peat contact above clayey silt with organics, and was dated to 280 to post-1950, indicating very young peat growth. At DP5, a wood sample retained at $0.55 \mathrm{~m}$ depth at the basal peat contact above clayey silt with organics also returned a date of 280 to post- 1950 . Deeper in the sediment profile at $0.80 \mathrm{~m}$, roots and sedge samples returned a date of 460 to $300 \mathrm{cal} \mathrm{BP}$.

\subsection{Summary}

Results of borehole drilling at BCSA revealed stratified domed layers of clayey silt, silty sand, and clay within the raised mound, whereas the same layers at depth appeared relatively flat under the adjacent peatland. There was no clayey silt layer in the near surface of the peatland; instead, the silty sand layer was twice as thick as the same sediment layer within the feature and appeared directly below the basal peat depth.

The first four metres of sediment within the feature contained medium to low VI $(<20 \%)$, and lenticular structures 1-4 mm thick were common. Below four metres depth, ice contents increased considerably. Layered ice lenses over $0.1 \mathrm{~m}$ thick were common within the lower clayey silts and clays.

Values of $\delta^{18} \mathrm{O}$ within boreholes were generally between -19 and $-15 \%$. An exceptional $\delta^{18} \mathrm{O}$ value of $-22 \%$ was recovered in near-surface peat. The $\delta^{18} \mathrm{O}$ values 
decreased by 1-2\%o within clays at depth. Geochemical results revealed that $\mathrm{Ca}^{2+}, \mathrm{K}^{+}$, $\mathrm{Mg}^{2+}$ and $\mathrm{SO}_{4}{ }^{2-}$ ion concentrations generally followed sediment stratigraphy, whereas $\mathrm{Cl}^{-}$ and $\mathrm{Na}^{+}$do not follow the same stratigraphic path. Radiocarbon dates provided a basal peat date in the peatland of approximately $1200 \mathrm{yr}$ BP, whereas plant material under small peat-filled depressions on the feature returned a date of approximately $400 \mathrm{yr}$ BP. The youngest date recovered in the feature was approximately $700 \mathrm{yr}$ BP under $3 \mathrm{~m}$ of sediment. 


\section{Chapter 5 Discussion}

This chapter provides interpretations on the results of fieldwork and laboratory tests, and links this work to existing literature to formulate a conceptual model of the geomorphic history of BCSA. The broader implications of similar features and the practical applications of the interpretations presented here for infrastructure projects are also briefly discussed.

\subsection{Stratigraphic interpretation and temporal scale}

\subsubsection{Stratigraphy}

The underlying clays at BCSA have a fine-grained texture indicative of a lowenergy deep-water environment (Smith 1994). They have been interpreted as glaciolacustrine deposits laid down in Glacial Lake McConnell between about 11.8 and $8.3 \mathrm{ka}$ cal BP (Aden 2014). The presence of isolated stones within the sediments supports the glaciolacustrine origins of the clays, as they likely represent ice-rafted glaciogenic drop stones (Bennett et al. 1996). Clay sediments were likely draped across the lake basin and collected into topographic lows when recession of Great Slave Lake began.

The lower clayey silts at BCSA are interpreted as originating in a slightly higherenergy lacustrine environment. High clay fractions within this lower clayey silt layer (Figure 4.12) still suggest a relatively deep-water depositional environment for these sediments.

The silty sand layer in the feature occurs between two clayey silt layers. A change from a deep-water depositional environment is interpreted to have occurred for the silty sand layer to be present at similar depths throughout the borehole stratigraphy. A shallow, higher-energy, near-shore depositional environment may have been present as 
ancestral Great Slave Lake further receded, similar to the environment of Yellowknife Bay that has a shallow, sandy bottom. The silty sand layer in the peatland, extending for over 2 metres directly below the peat-mineral interface, is approximately twice as thick as the silty sand layer within the feature. The increased thickness of the silty sand layer may indicate a higher rate of near-shore deposition relative to other locations, or that the area adjacent to the bedrock outcrop was a near-shore environment for a longer period of time. Within the last $2 \mathrm{ka} \mathrm{BP}$, the ancestral Great Slave Lake recession rate has decreased to approximately $2 \mathrm{~m} / \mathrm{ka} \mathrm{BP}$ (Smith 1994), potentially causing extended deposition of silty sand at BH01, and then, as recession continued, at BH02-05. Nearby Boundary Creek may have served as a source of depositional material when Boundary Creek met ancestral Great Slave Lake during lake recession. Boundary Creek may once have been a larger feature on the landscape, depositing sandy alluvial sediments at BCSA. Channel migration of Boundary Creek could also have resulted in a large amount of sandy sediments in an embayed area at BCSA.

The upper clayey silt layer occurs just below the organic layer and is absent below the peatland. The upper clayey silts are interpreted to have been deposited over the nearshore silty sand in a low-energy pond environment, which did not extend to the peatland area at the time of deposition.

By examining the stratigraphic layers in Figure 4.12, a pattern emerges within the feature. All layers of sediment appear to follow the general topography of the feature. The interface of the clayey silts and the clays is also domed in a similar fashion, implying a significant amount of ground ice within the underlying clays below the termination depths of the boreholes. Figure 4.10 demonstrates that, under the assumption that ground 
ice is the sole reason for the difference in topographic relief, an excess of $1.83 \mathrm{~m}$ of ice remains unaccounted for beneath the peak of the feature (BH04 a+b).

\subsubsection{Timing}

Table 5.1 presents the radiocarbon dates used in this interpretation as well as their implied significance. The detrital organics found in sediments of the peatland as well as the feature are interpreted as lacustrine or alluvial in origin. Burned wood pieces under the peatland were dated to approximately 1700 and $1450 \mathrm{yr}$ BP. The older sample was recovered $0.35 \mathrm{~m}$ above the younger date. The detrital organics were probably not buried in-situ, but instead were likely transported as alluvium from a terrestrial source and deposited locally, explaining the date reversal.

The basal peat date in $\mathrm{BH} 01$ indicates that a water body was likely present over the entire study area until at least 1270 to 1070 cal BP when terrestrial emergence, peat accumulation, and subsequent permafrost aggradation began. A detrital sample found in BH12 dated at 720-660 cal BP implies that lacustrine or alluvial deposition continued at the location of the now-formed feature after this time period. More than $3 \mathrm{~m}$ of sediment between the sample and the surface of the feature indicate continued and rapid deposition for some time before emergence. The sample taken from borehole DP5 at $0.80 \mathrm{~m}$ returned an age of 460 to $300 \mathrm{cal} \mathrm{BP}$, and was composed of roots and sedges, indicative of a damp environment. This provides evidence that the feature's surface was exposed much later than the surface of the peatland, and the damp environment at DP5 suggests a depression over the once-flat surface of the feature between approximately 700 and 400 yr BP. Lacustrine or alluvial deposition of silty sand and upper clayey silt likely continued over the area throughout this 300-year time period, followed by terrestrial 
Table 5.1: Radiocarbon samples used in the temporal interpretation of BCSA and their implied significance.

\begin{tabular}{|c|c|c|c|c|c|}
\hline $\begin{array}{c}\text { Beta } \\
\text { Analytic lab } \\
\text { number }\end{array}$ & Borehole & $\begin{array}{l}\text { Depth } \\
\text { (m) }\end{array}$ & Sample type & Date (cal BP) & $\begin{array}{l}\text { Interpretation/date } \\
\text { significance }\end{array}$ \\
\hline 317798 & BH01 & 2.2 & Burned wood & $1770-1610$ & $\begin{array}{l}\text { Continuing deposition at } \\
\text { the peatland }\end{array}$ \\
\hline 317799 & ВH01 & 2.55 & Burned wood & $1510-1420$ & $\begin{array}{l}\text { Continuing deposition at } \\
\text { the peatland }\end{array}$ \\
\hline 309321 & BH01 & 0.93 & Basal peat & $1270-1070$ & $\begin{array}{l}\text { Terrain emergence and } \\
\text { permafrost aggradation } \\
\text { at the peatland }\end{array}$ \\
\hline 331114 & BH04 & 3.5 & Detrital organic & $720-660$ & $\begin{array}{l}\text { Continuing deposition } \\
\text { over the once-flat feature }\end{array}$ \\
\hline 328918 & DP5 & 0.8 & $\begin{array}{l}\text { Plant material in } \\
\text { sediment }\end{array}$ & $460-300$ & $\begin{array}{l}\text { Small depression in the } \\
\text { once-flat feature, a damp } \\
\text { environment, likely no } \\
\text { permafrost }\end{array}$ \\
\hline 328917 & DP1 & 0.33 & Wood in basal peat & 280 -post 1950 & $\begin{array}{l}\text { Terrestrial emergence } \\
\text { and likely permafrost } \\
\text { aggradation }\end{array}$ \\
\hline 328119 & DP5 & 0.55 & Wood in basal peat & 280-post 1950 & $\begin{array}{c}\text { Terrain emergence and } \\
\text { permafrost aggradation } \\
\text { at the feature }\end{array}$ \\
\hline
\end{tabular}


emergence and permafrost aggradation. Woody material sampled at the base of peat from the small peat pockets (DP1 and DP5) produced modern ages of 280 to post-1950 cal $\mathrm{BP}$ at $0.33 \mathrm{~m}$ and $0.55 \mathrm{~m}$, indicating that terrestrial emergence and ensuing permafrost aggradation had occurred by this time. Terrestrial emergence of the feature and permafrost aggradation therefore likely occurred within the last 700 to 400 years, some 800 to 500 years after terrestrial exposure at the peatland. The 700 to 400 cal BP timeframe is consistent with the temporal scale described by Harris (1993) for lithalsa formation to take place (380 years or more).

\subsection{Lithalsa interpretation}

The results of this thesis provide several lines of evidence in support of the hypothesis that the raised feature at BCSA is a lithalsa, and not another ice-rich feature such as a pingo, palsa, or seasonal frost mound. The lack of sandy sediments (Stevens et al. 2012a) and extended drained lakes throughout the Lowlands, as well as characteristically warm permafrost at BCSA inhibit closed-system pingo formation such as those found in the Mackenzie Delta, and as such, no pingos have been recognized in the Lowlands.

The feature at BCSA has a thin organic layer on the order of $0.10 \mathrm{~m}$ and is composed primarily of deadfall. The lack of continuous peat cover confirms that the landform at BCSA is, by definition, not a palsa (Pissart 2002). Also, the lack of physical variation in the feature with the seasons indicates that the feature is not a seasonal frost mound such as frost blister, but should instead be categorized as a perennial frost mound (Pollard 2008). The lack of peat cover and the layered ice core between silty and clayey 
sediments at depth is indicative of a lithalsa (Allard et al. 1996, Pissart 2002, Calmels et al. 2008).

The results of this study support the three primary conditions needed for formation of lithalsas (Wolfe et al. 2014): 1) a "warm" permafrost ground regime, i.e. a low ground thermal gradient at the time of inception and subsequent growth; 2) an available groundwater supply; and 3) fine-grained sediment. First, the Lowlands are located in an area of extensive discontinuous permafrost, and ground temperatures below 2-m depth at BCSA range between 0 and $-1{ }^{\circ} \mathrm{C}$ (Figure 3.2). The warm permafrost inhibits rapid freezing of the lower mineral sediment due to the low thermal gradient, thus promoting ice segregation. Second, the Lowlands are characteristically associated with bedrock outcrops and many ponds and small lakes across the region, providing adequate, channeled water to support growth of ice lenses. Third, the fine-grained sediment laid down by Glacial Lake McConnell and ancestral Great Slave Lake are conducive to constant cryosuction, due in large part to the high unfrozen water contents at temperatures below $-1{ }^{\circ} \mathrm{C}$ characteristic of clayey sediments (Washburn 1979; Osterkamp and Burn 2003).

Pissart $(2000,2002)$ noted that lithalsas form in specific environmental settings, and predicted that lithalsas could grow in areas north of Great Slave Lake: lithalsas would be restricted to the discontinuous permafrost zone, close to tree line, and MAATs ranging from -4 to $-6^{\circ} \mathrm{C}$. The location and MAAT of BCSA $\left(-4.6^{\circ} \mathrm{C}\right.$ at Yellowknife) supports all of Pissart's $(2000,2002)$ criteria for lithalsa formation north of Yellowknife, although temperatures may have been slightly cooler than present when the lithalsas in the Lowlands formed. 
The BCSA lithalsa is a linear feature, not circular as are the lithalsas studied by Allard et al. (1996), Calmels et al. (2008), and Wünnemann et al. (2008). The lithalsa is likely linear due to local spatial configuration in the Lowlands of bedrock outcrops, topographical lows filled with clay, and lake and pond locations. These topographical restrictions constrain the movement of ground water, and appear to be one of the controlling factors in lithalsa formation and shape in the Lowlands (Wolfe et al. 2014).

Unrestricted growth of circular lithalsas was witnessed by Allard et al. (1996) and Calmels et al. (2008). Circular palsas and lithalsas appear predominantly within flat peatlands or lake basins where the surrounding topography has minimal restriction on groundwater movement and potential migration toward the freezing front.

Lithalsas in the Akkol Valley in Siberia appear more linear than lithalsas in Yukon and northern Quebec (Iwahana et al. 2012). Iwahana et al. (2012) reported peculiar spatial distributions of lithalsas in the Akkol Valley. These lithalsas appear to be connected to erosive conditions and lake formation in mountainous regions. Although the ecological environment of the Akkol Valley is different from that of the Great Slave Lowlands, the distribution of lakes and ponds throughout the region appear to be a large factor in lithalsa distribution at both BCSA and the Akkol Valley. Both sites have similar characteristics such as fine-grained sediment, similar MAATs $\left(-4.6^{\circ} \mathrm{C}\right.$ at Yellowknife; $-4.0^{\circ} \mathrm{C}$ at Akkol Valley) and lithalsa formation criteria based on sources of water (e.g., the studied lithalsa in the Akkol Valley was located adjacent to a 50-m wide pond). Both sites experienced what has been interpreted as shallow water lacustrine deposition as well as earlier glacial lake deposition (Iwahana et al. 2012).

\subsection{Ground cracking and continued growth}


Ground cracking up to $0.20 \mathrm{~m}$ deep was apparent both parallel and perpendicular to the long axis of the lithalsa. This cracking can be interpreted in two ways: first, as a result of degradation, as surficial material could have detached and crept downslope; and second, as dilation cracks similar to those of a pingo where cracks have formed in the ground surface as a result of upward heave (Mackay 1985). The latter explanation is considered most likely. Slumping would only occur perpendicular to, and not parallel to, the flat terrain of the lithalsa's long axis. Dilation cracks, as well as ground temperatures at depth $\left(<-1^{\circ} \mathrm{C}\right.$; Figure 3.2) and the presence of unfrozen clays, suggest that this feature is not necessarily degrading, and may be continuing to heave.

\subsection{Ground ice and cryostructures}

\subsubsection{Unaccounted ice}

As noted in section 4.4, ground ice recorded in BH04 $(\mathrm{a}+\mathrm{b})$ accounts for approximately $54 \%$ of the lithalsa's raised topography in relation to the sediment reference height (Figure 4.10). Assuming the ground ice accumulation is the reason for the lithalsa's raised topography on the landscape, then a portion of the topography in the feature is unaccounted for in the borehole records. A large quantity of ground ice may be located deeper than the maximum drilling depth achieved because the amount of ice found in each borehole is not a 1:1 relation with feature height. Unaccounted relief is $0.63 \mathrm{~m}$ at $\mathrm{BH} 02,1.88 \mathrm{~m}$ at $\mathrm{BH} 03,1.83 \mathrm{~m}$ at $\mathrm{BH} 04(\mathrm{a}+\mathrm{b})$, and $0.74 \mathrm{~m}$ at $\mathrm{BH} 05$. The accumulation of more ground ice than measured is plausible because the depth to bedrock is confirmed to be more than $10.3 \mathrm{~m}$ below the feature's surface. Borehole results indicate increasing ice content with depth, with high ice contents more than $4 \mathrm{~m}$ from the surface. Visible ice did not decrease near the borehole termini. 


\subsubsection{Cryostructures}

Cryostructures within the sediment profile provide insight on the formation process of the lithalsa's ice-based core at depth. The cryostructures at BCSA varied substantially throughout the profile. Lenticular structures on the order of $1 \mathrm{~mm}$ were common in the generally ice-poor top $4 \mathrm{~m}$ of substrate. Larger lenticular structures 50 $100 \mathrm{~mm}$, or thicker, were common below 4-m depth in the clays.

The potential for buried glacial ice at BCSA was first dismissed when it was determined that the clays at depth are a result of glaciolacustrine deposition from Glacial Lake McConnell, in which large ice bodies below $4 \mathrm{~m}$ are layered ice between mineral sediment. This is confirmed by stable isotope data in the literature, which provide a $\delta^{18} \mathrm{O}$ value range of -26 to $-36 \%$ for glacial ice (Michel 2011), and do not match the isotopic results gathered from the ice lenses at BCSA (Figure 4.13). Further, the lack of an obvious erosional unconformity within the substrate (Iwahana et al. 2012), as well as matching layers of mineral sediments within boreholes throughout heaved and nonheaved areas of BCSA, eliminate buried glacial ice as a possible ground ice source.

The structures of ice in the lithalsa appear similar to sections of Iwahana et al.'s (2012) internal lithalsa composition, such as reticulate structures of thick ice veins, lenticular lenses, and ice veins suspended within sediment fragments. Due to the borehole sampling method at BCSA it is impossible to describe lenses as "wavy" as Iwahana et al. (2012) described them, or continuous, because no cross-sectional exposures were available at BCSA so large-scale patterns in the ice were hidden.

The cryostratigraphy of abundant lenses $1-10 \mathrm{~mm}$ thick is similar to some sections of the lithalsa in the Akkol Valley (Iwahana et al. (2012), those in northern 
Quebec (Allard et al. 1996; Calmels and Allard 2008, Calmels et al. 2008) and in northern India (Wünnemann et al. 2008). The ice at BCSA was sometimes nonhorizontally oriented, suggesting that ice formed either in vertical veins, or ground heave was responsible for the reorientation of horizontal lenses. Allard et al. (1996) alluded to the presence of segregated ice lenses parallel to the flat surface of the lithalsa, and Calmels et al. (2008) explained that this was due to thermal gradients running vertical to the flat top of the feature. Many of the lenses recovered at BCSA appeared horizontal in the core. However, some heavily tilted lenses $\left(30-60^{\circ}\right)$ were recorded within $\mathrm{BH} 03$, BH04b, and BH05 and appear similar to Iwahana et al.'s (2012) description of ice lenses within a lithalsa as generally tilted in orientation. In contrast, the ground surface at BH05 sloped northward at an approximate $20^{\circ}$ angle.

The key observation of tilted lenses 30 to $60^{\circ}$ suggests ice lenses had already formed within the substrate before being heaved further. Ongoing ice segregation at depth was likely responsible for heaving the ground and displacing the lenses which formed closer to the surface. This may account for the tilted lenses seen in some sections of the profile. The discrepancy between the $20^{\circ}$ surficial slope and 30 to $60^{\circ}$ tilted lenses may be explained by potential downslope sediment movement perpendicular to the lithalsa's long axis, and, probably, at the lithalsa's east and west termini. As aggrading ice lenses domed the ground surface, the angle of repose of the lithalsa slope may have been surpassed, and surficial material would have collected at the base of the mound. As heaving continued, more surficial material was likely displaced to stabilize the slope; however, the ice lenses within the lithalsa remained tilted at the same angle. This downslope movement hypothesis is a potential source of excess sediment that forms a 
ringed rampart on more circular degraded lithalsa features witnessed throughout the Lowlands (Figure 2.8), however no further evidence of downslope movement, in addition to the ground cracking and tilted lenses, was visible on the ground surface.

As discussed in section 2.3.6, Allard et al. (1996) subdivided the internal composition of a lithalsa into 3 distinct sections: An ice-rich section below the active layer, an ice-poor section $2.5 \mathrm{~m}$ thick, and an ice-rich section at the bottom of permafrost. This stratigraphy is similar to that of BCSA, but there is minimal near-surface ground ice at the base of the active layer. This could be due to the lithalsa's young age, suggesting a lack of time for near-surface ground ice accumulation. A more likely scenario is that the lithalsa is inherently dry and well drained, minimizing the accumulation of near-surface ground ice from surficial water infiltration. O’Neill and Burn's (2012) examination of near-surface aggradational ground ice development supports the latter explanation.

The presence of bubble structures was noted within thick ice lenses at the sediment-clay contact points in BH05 and suggests that the segregated ice indicates migration of water as permafrost aggraded into the mineral sediments at depth (Calmels and Allard 2008). The stiff clay layers between thick ice lenses indicate consolidation during ice lens growth.

Most of the ground ice within the lithalsa occurs in the underlying McConnell clays. Comparing the difference in height at the top of the underlying clay unit between the peatland (BH01) and the lithalsa (BH04), the build-up of ground ice at depth has led to approximately $2.8 \mathrm{~m}$ of heave (Figure 4.12). 


\subsection{Isotopic analysis}

\subsubsection{Isotopic representation at BCSA}

Major shifts of $\delta^{18} \mathrm{O}$ values within ice cores are generally seen in the transition between the colder Pleistocene and warmer Holocene. Colder conditions during the Wisconsinan glaciation generally caused $\delta^{18} \mathrm{O}$ values to be more negative in the sediment substrate (Moorman et al. 1996). Based on the timescales of sediment deposition across the region, the isotopic results from BCSA are a reflection of the warmer Holocene period.

\subsubsection{Rainwater}

Near-surface $\delta^{18} \mathrm{O}$ values at BCSA, specifically at $\mathrm{BH} 01$ and $\mathrm{BH} 02$, vary widely likely due to the replacement of sediment pore water by seasonal precipitation or surface runoff flowing through the active layer (Michel 2011). The freeze-thaw cycles of the active layer could explain the variability of $\delta^{18} \mathrm{O}$ values within the first $1-2 \mathrm{~m}$ of the sediment profiles.

The local rainwater sample taken in Yellowknife plots below the LMWL (Figure 5.1). This value may be attributed to the sampling method of rainwater, as rainwater collected in a bucket was exposed to the open environment after the rain event, permitting evaporation and depletion to occur.

There was a statistically significant difference between the $\delta^{18} \mathrm{O}$ value of rainwater collected in Yellowknife and isotopic values found at depth. $\delta^{18} \mathrm{O}$ values of ice lens water recovered within the lithalsa and the peatland are 1-7\%o more negative than those from local summer water sources collected in the field (Figures 5.1, 5.2). Rainfall records from Gibson and Reid (2010), however, indicate a large range of $\delta^{18} \mathrm{O}$ values 


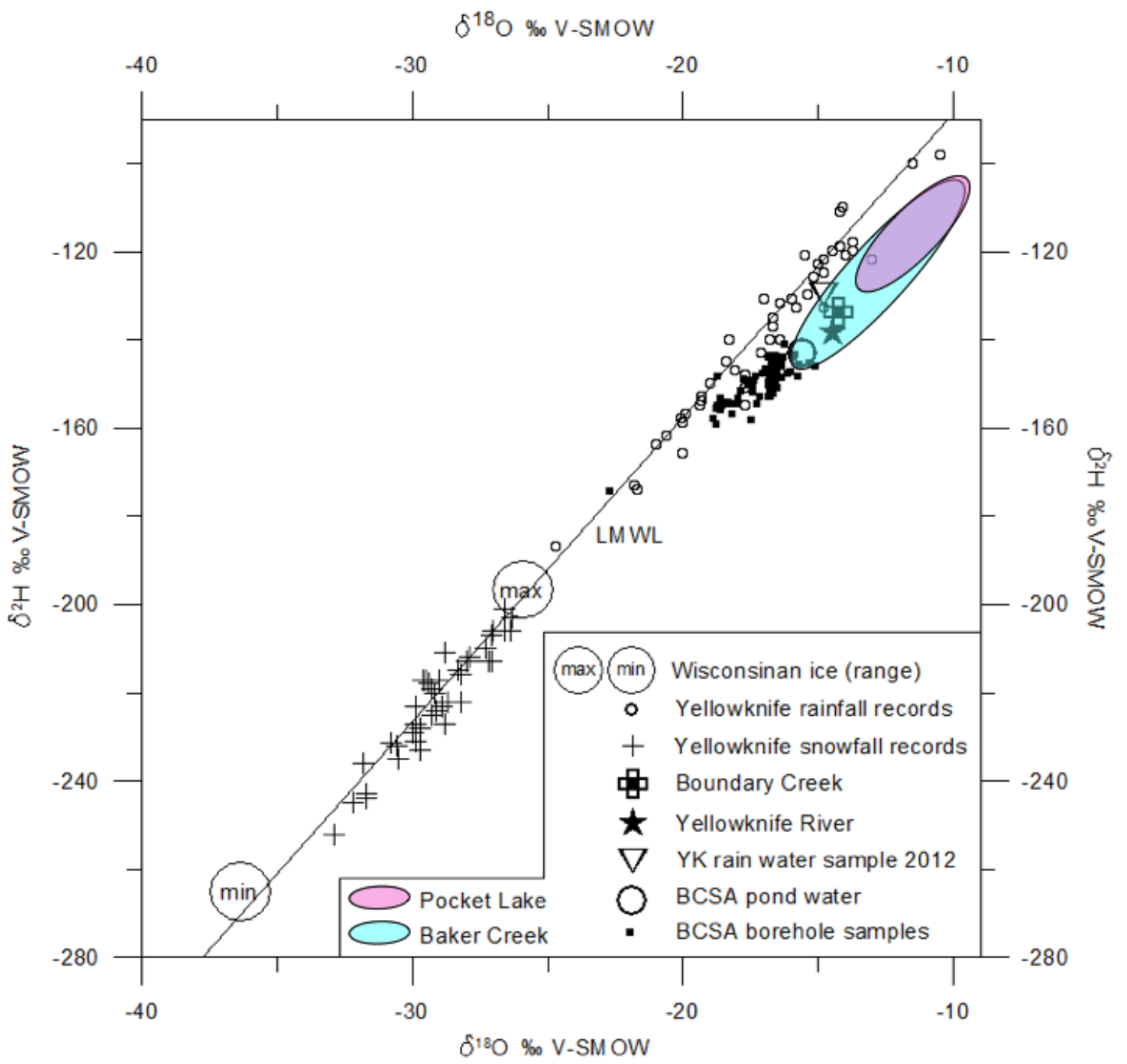

Figure 5.1: Stable isotope plot of $\delta^{2} H$ and $\delta^{18} O$ values for all borehole and water sampling results at BCSA and the surrounding region, alongside isotopic values of Wisconsinan ice (Michel 2011), historical Yellowknife rainfall and snowfall records, and records from Baker Creek and Pocket Lake (Gibson and Reid 2010). Local Meteoric Water Line $=6.91 x-19.53$. 


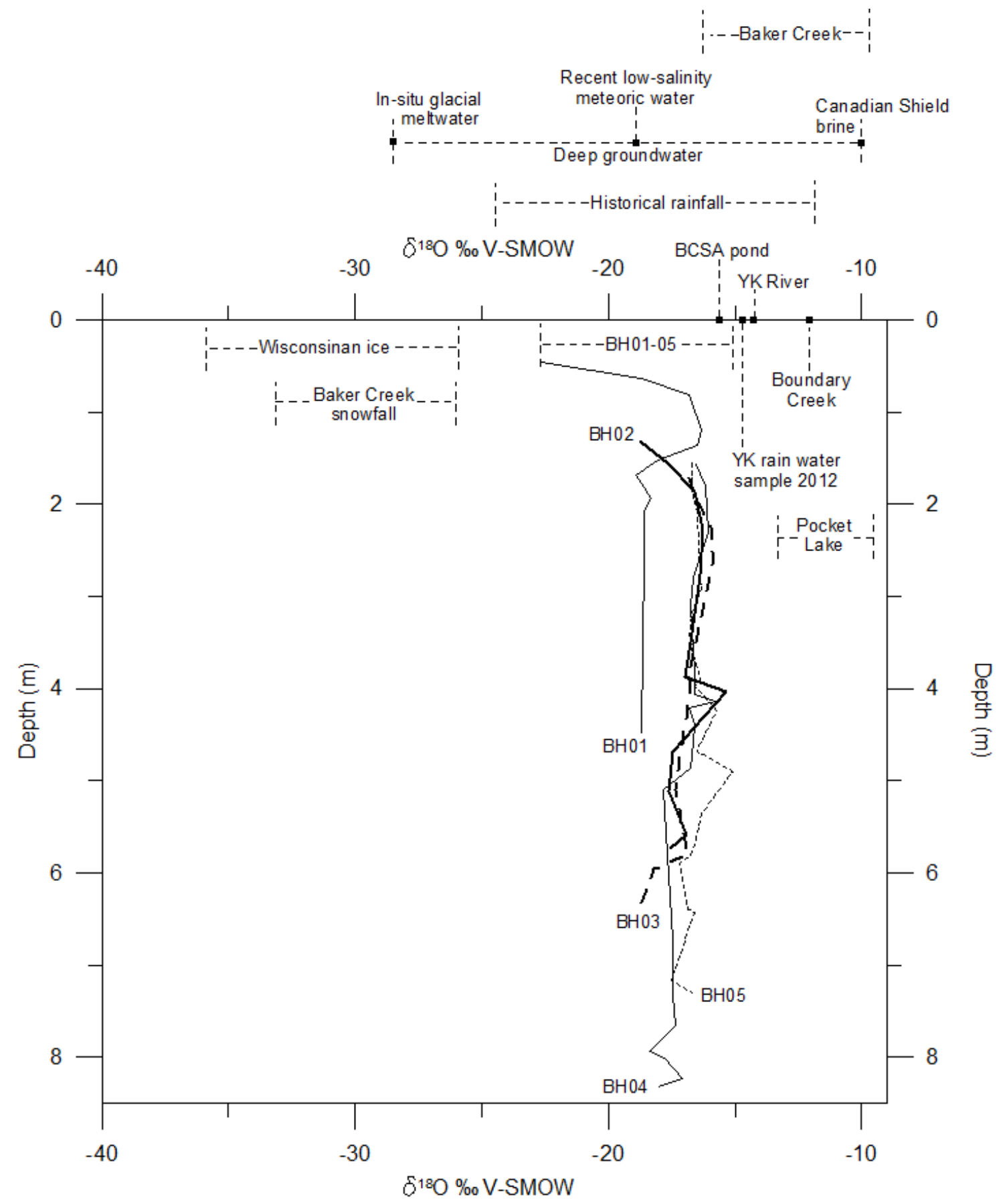

Figure 5.2: $\delta^{18} O$ values of BH01-05 with depth at BCSA, plotted with $\delta^{18} O$ values of local samples. Also indicated are the ranges in $\delta^{18} \mathrm{O}$ values for historical Yellowknife rainfall and Baker Creek snowfall records (Gibson and Reid 2010), as well as the range of Wisconsinan glacial ice (Michel 2011). 
(approximately -22 to $-11 \%$ ). With the exception of one sample recovered in nearsurface peat, all $\delta^{18} \mathrm{O}$ values from BCSA boreholes are within this range, suggesting much of the ice at BCSA is formed from surface water derived from rain.

\subsubsection{Local water bodies and comparable $\delta^{18} \mathrm{O}$ values in the literature}

Iwahana et al. (2012) determined that, based on $\delta^{18} \mathrm{O}$ values of lens ice compared to local water sources, most of the excess ice within the lithalsa in the Akkol Valley originated from a nearby pond. Gibson and Reid (2010) sampled Pocket Lake and Baker

Creek, both near Yellowknife. They reported $\delta^{18} \mathrm{O}$ values from Pocket Lake less negative than samples taken from borehole samples at BCSA (Figures 5.1, 5.2). Baker Creek values were similar to samples taken in 2012 from nearby Yellowknife River, from the more westerly Boundary Creek near BCSA, as well as from the BCSA pond and the local rainfall sample. Some $\delta^{18} \mathrm{O}$ samples from BCSA boreholes are within the value range of Baker Creek. Local water sources, especially the adjacent BCSA pond $\left(\delta^{18} \mathrm{O}\right.$ value of $-15.6 \%$, Figures 5.1, 5.2) appear to be key sources of water for ice segregation within the frozen sediments.

\subsubsection{The effect of snow on $\delta^{18} \mathrm{O}$ values}

A relatively low $\delta^{18} \mathrm{O}$ value of $-22.7 \%$ was obtained at $0.45 \mathrm{~m}$ depth in BH01 within peat (Figure 4.2). This more negative value in relation to lithalsa boreholes suggests an increased influence of snow on groundwater composition in the near surface. Local historical snowfall values range from -34 to $-26 \%$ (Gibson and Reid 2010) (Figures 5.1, 5.2). The ground surface of the lithalsa is well drained, thus snowmelt runoff would move to areas of lower relief. Less snow may be also present on the lithalsa due to canopy interception, whereas the lower topography of the peatland, in conjunction 
with the adjacent bedrock outcrop, could act as a snow catchment. During spring melt, more snowmelt could have percolated into the deepening active layer, accounting for the more negative $\delta^{18} \mathrm{O}$ values observed in the near surface.

\subsubsection{Variations of $\delta^{18} \mathrm{O}$ at depth}

Minor variations of $\delta^{18} \mathrm{O}$ indicate two key points: 1) small amounts of fractionation below 4-m depth in all deep boreholes may represent a stabilized freezing front at $\mathrm{BCSA}$; and 2) the minor $\delta^{18} \mathrm{O}$ variations in the clay in $\mathrm{BH} 04$, on the order of $1-2$ \%o, may represent an abundant water supply (Iwahana et al. 2012). Depletion of $\delta^{18} \mathrm{O}$ occurs when water freezes in closed systems (Michel 2011), however variations of only 1-2 \%o throughout the borehole stratigraphy suggest an open groundwater system at BCSA and ample water supply (Iwahana et al. 2012).

It should be noted that lithalsa ice was statistically significantly more negative in $\delta^{18} \mathrm{O}$ in the clay layer than above the clay layer in BH04 (Figure 4.6). This leaves open the possibility that, upon clay consolidation and pore water expulsion, some older pore water within the particles at the time of Glacial Lake McConnell deposition contributed to the more negative isotopic composition of samples at depth.

\subsubsection{Groundwater mixing dynamics}

Douglas et al. (2000) reported deep-seated groundwater $\delta^{18} \mathrm{O}$ values from Con Mine near Yellowknife (Figure 5.2). The $\delta^{18} \mathrm{O}$ end-member values ranged from -10 to $-28 \%$ depending on its original source and mixing at depth. Canadian Shield brine was the least negative, possessing a $\delta^{18} \mathrm{O}$ value of $-10 \%$, reflective of the most saline waters at the site. Recent low-salinity meteoric water returned a $\delta^{18} \mathrm{O}$ value of $-18 \%$. In-situ glacial water provided a $\delta^{18} \mathrm{O}$ value of $-28 \%$, and is a representative value from the 
Laurentide Ice Sheet. The wide variation of $\delta^{18} \mathrm{O}$ values demonstrates the mixing dynamics that can occur at depth, and is applicable to BCSA in regards to dilution effects of infiltrating meteoric water and pore water within the substrate on reported $\delta^{18} \mathrm{O}$ values.

\subsubsection{Summary}

The ice at BCSA appears to be composed of modern meteoric waters including summer rainwater with a minor influence from snow, as well as small water bodies that reflect $\delta^{18} \mathrm{O}$ levels of precipitation influenced by evaporation. There is also a possibility that pore water expelled from clay sediments may have some influence at depth. Minor $\delta^{18} \mathrm{O}$ variations at depth indicate that BCSA has an open groundwater system.

\subsection{Geochemical analysis}

\subsubsection{Near-surface ion concentrations}

In 1972, J. R. Mackay introduced the notion of aggradational ice in the ice-rich zone, just below the active layer. While it is now known that the ice-rich zone is widespread in permafrost terrain, little was known about its geochemical characteristics before the work of Kokelj and Burn (2003, 2005). Leaching of seasonally thawed soils can contribute to a geochemical contrast between the active layer and subjacent permafrost. In freezing soils, thermally-induced moisture migration is accompanied by ionic redistribution, suggesting that the zone of near-surface aggradational ice may be enriched with solutes (Kokelj and Burn 2003).

At BCSA, the highest ionic concentration levels generally appeared within the near-surface active layer (Figure 4.14). Kokelj and Burn (2003) noted the opposite in the Mackenzie Delta region, as soluble cation concentrations were greater in permafrost than 
in mineral sediments of the overlying active-layer, and zones of cation accumulation in near-surface permafrost corresponded with ice-rich intervals. At BCSA, a zone of icerich material was not present in the near surface, yet ion concentrations remained high. At $\mathrm{BH} 04$, two large increases in ion concentrations were noted in the near surface. First, a $\mathrm{Ca}^{2+}$ concentration of $13.0 \mathrm{mEq} / \mathrm{L}$ appeared at $0.30 \mathrm{~m}$ depth just below the unfrozen organic layer, suggesting sediment reworking and weathering within the active layer, as well as evaporation of infiltrating surface water.

Second, below the thaw depth at BH04 $(\mathrm{a}+\mathrm{b})$, in the upper silty sand, $\mathrm{Ca}^{2+}$ concentrations decreased to $3.4 \mathrm{mEq} / \mathrm{L}$, then at approximately $1.30 \mathrm{~m}$ depth at the silty sand and clayey silt interface, $\mathrm{Ca}^{2+}$ increased to $9.6 \mathrm{mEq} / \mathrm{L}$. In near-surface permafrost, increasing soluble cation concentrations with depth suggest removal and redistribution of solutes during periods of deeper thaw (Kokelj and Burn 2003). Since thaw depths were measured in early summer, the increase in ions at $1.30 \mathrm{~m}$ could be interpreted as the maximum thaw depth of the active layer and where solutes accumulate.

\subsubsection{Ion migration}

A major constraint on summer moisture migration into permafrost is that temperature, and therefore hydraulic conductivity, declines with depth (Kokelj and Burn 2003). Downward migration of water is also inhibited by ice lenses that may decrease the soil's permeability at temperatures just below $0^{\circ} \mathrm{C}$ (Burt and Williams 1976) and therefore at locations of high VI. At BCSA, permafrost is coldest at 3-m depth (Figure 3.2). Temperatures below approximately $3-\mathrm{m}$ depth increase; therefore water migration through the substrate was less inhibited due to temperature below this depth, yet more inhibited by higher ground ice contents. 


\subsubsection{Trends in ion concentrations}

\subsubsection{Calcium and associated ions}

In BH05 (Figure 5.3) $\mathrm{Ca}^{2+}$ concentrations decreased in clayey silt to a minimum of $3.17 \mathrm{mEq} / \mathrm{L}$ at $3.78 \mathrm{~m}$, then increased considerably at $4.21 \mathrm{~m}$ to $8.99 \mathrm{mEq} / \mathrm{L}$ where high VI occurred (up to $50 \% \mathrm{VI}$ ), suggesting increasing ionic concentrations in the icerich zone (Kokelj and Burn 2003). The $\mathrm{Ca}^{2+}$ trended with the stratigraphic sediment layers and areas of ice-rich sediment in the near surface (Figure 5.3), slowly decreasing with depth. The $\mathrm{Ca}^{2+}$ then decreased substantially from $8.99 \mathrm{mEq} / \mathrm{L}$ to a minimum of $1.35 \mathrm{mEq} / \mathrm{L}$ at $5.95 \mathrm{~m}$ in clay. One explanation for higher $\mathrm{Ca}^{2+}$ concentrations in the upper $4 \mathrm{~m}$ and low concentrations in clays is that different sources of groundwater had moved through the substrate at different time periods within the open groundwater system. Due to the rapid increases and decreases in concentrations, however, the more likely explanation is that the geochemical properties of the different sediments are the controlling factors on $\mathrm{Ca}^{2+}$ concentrations.

\subsubsection{Sodium chloride}

$\mathrm{Cl}^{-}$did not follow the same trends as $\mathrm{Ca}^{2+}$ throughout the profiles. In all boreholes (BH01-05, Appendices I.1 to I.5), $\mathrm{Cl}^{-}$transcended clayey silt, silty sand, and clay, while gradually increasing with depth. $\mathrm{Cl}^{-}$concentrations were relatively high in the active layers of all boreholes, and then decreased rapidly by 0.3 to $0.9 \mathrm{mEq} / \mathrm{L}$ in frozen sediments. These trends are illustrated in Figure 5.3 (BH05). A rapid $\mathrm{Cl}^{-}$increase occurred in the deepest borehole samples, suggesting different geochemical properties within the clay sediments at this location.

The $\mathrm{Na}^{+}$concentrations in $\mathrm{BH} 05$, like $\mathrm{Cl}^{-}$, gradually increased with depth after an 


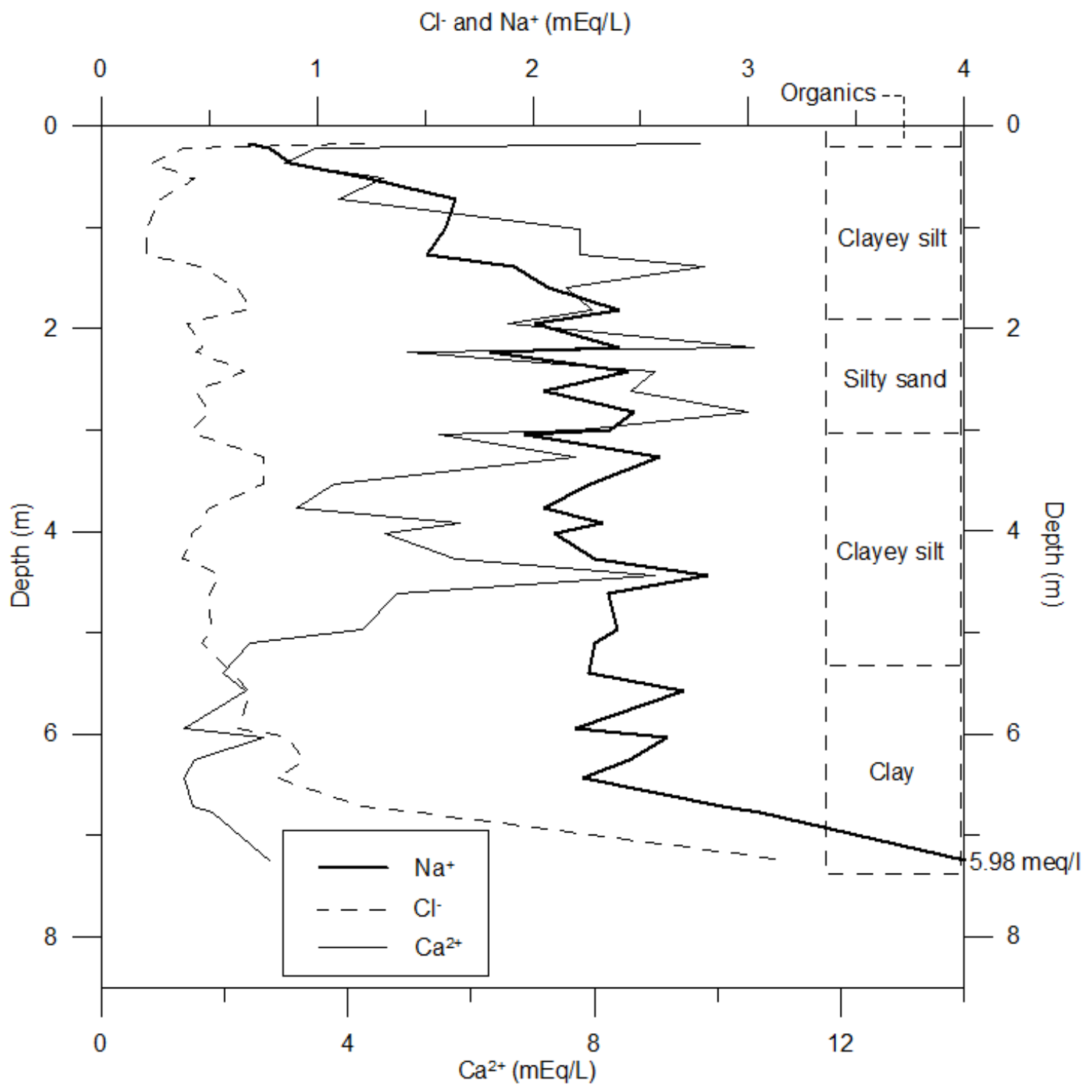

Figure 5.3 Profile of $\mathrm{BH} 05$ with $\mathrm{Ca}^{2+}, \mathrm{Cl}$ and $\mathrm{Na}^{+}$indicated. Sediment stratigraphy is also shown. 
initial rapid increase above $2-\mathrm{m}$ depth, and then increased substantially, from $2.23 \mathrm{mEq} / \mathrm{L}$ at $6.43 \mathrm{~m}$ to $5.98 \mathrm{mEq} / \mathrm{L}$ at $7.24 \mathrm{~m}$ in BH05 (Figure 5.3). This again suggests a difference in geochemical properties of the clay sediment, as groundwater in an open system is not likely to rapidly change ion concentrations. The unfrozen clay section in BH05 was also at this depth $(6.75 \mathrm{~m})$. Since solutes generally lower the freezing point of a liquid, greater concentrations of solutes result in a lower freezing point depression (Konrad and McCammon 1990). The large increase in sodium chloride at depth may account for the unfrozen clays in BH05.

\subsection{Electrical resistivity corroboration}

The parallel study conducted by Oldenborger (2012), first discussed in Section 3.1.6, revealed the presence of potentially unfrozen ground next to the pond at BCSA, as well as under the peatland and forest. Together with the borehole result of unfrozen clay at $6.75 \mathrm{~m}$ in $\mathrm{BH} 05$, the presence of unfrozen ground in the lithalsa, under the peatland, and under the pond, has two significant implications. First, moisture may be mobile within the substrate throughout sections of BCSA. The unfrozen sediment allows water within the ground to migrate more easily toward the freezing front or ice lenses, facilitating the growth of the sub-surface ice core. Second, unfrozen ground results in the possibility that the lithalsa is still actively growing, not degrading. Because there is unfrozen sediment under the lithalsa and unfrozen sediment beneath the pond, as well as warm permafrost temperatures $\left(<-1^{\circ} \mathrm{C}\right)$, the active migration of water toward the freezing front may still be occurring.

\subsection{Conceptual model of landscape evolution}


Based on the results and interpretations presented in Chapters 4 and 5, a conceptual model of the geomorphic history of BCSA throughout the Holocene is presented in Figure 5.4, explaining the presence of the lithalsa on the landscape.

The chronology begins at 11.8 cal ka BP, when Glacial Lake McConnell covered the Great Slave Lowlands to depths of over $100 \mathrm{~m}$ (Figure 5.6a). Fine-grained clays were deposited within topographic lows and basins of the undulating bedrock on the lake bottom. These clays were draped over the landscape, and any sediment deposited on top of higher relief was washed off as lake levels receded.

As water levels lowered, Glacial Lake McConnell ended around 9.5 to $8.3 \mathrm{cal} \mathrm{ka}$ $\mathrm{BP}$ as isostatic rebound progressively separated the Great Bear, Great Slave and Athabasca lake basins (Figure 5.6b) (Smith 1994). Shallow-water lacustrine deposition took place similar to the deep-water clays, but with a slightly higher-energy environment. The result is a layer of clayey silt over a layer of finer clays.

Lake levels continued to recede over the terrain at BCSA. Eventually, the bedrock outcrop was exposed, and near-shore deposition took place at approximately 2 cal ka BP, resulting in a layer of near-shore silty sand deposited over the shallow water clayey silt at what is now the peatland (Figure 5.6c). Boundary Creek may have also contributed to the sandy sediment accumulation via channel migration, creating an embayed area. Alluvial deposition added to the sandy sediments.

Terrestrial emergence of the mineral substrate that is now under peat occurred at approximately $1.2 \mathrm{ka} \mathrm{BP}$. As lake levels continued to recede over BCSA, near-shore deposition of silty sands occurred at the area that later became the lithalsa (Figure 5.6d). As terrestrial exposure occurred due to continued lake level recession, the formation of 


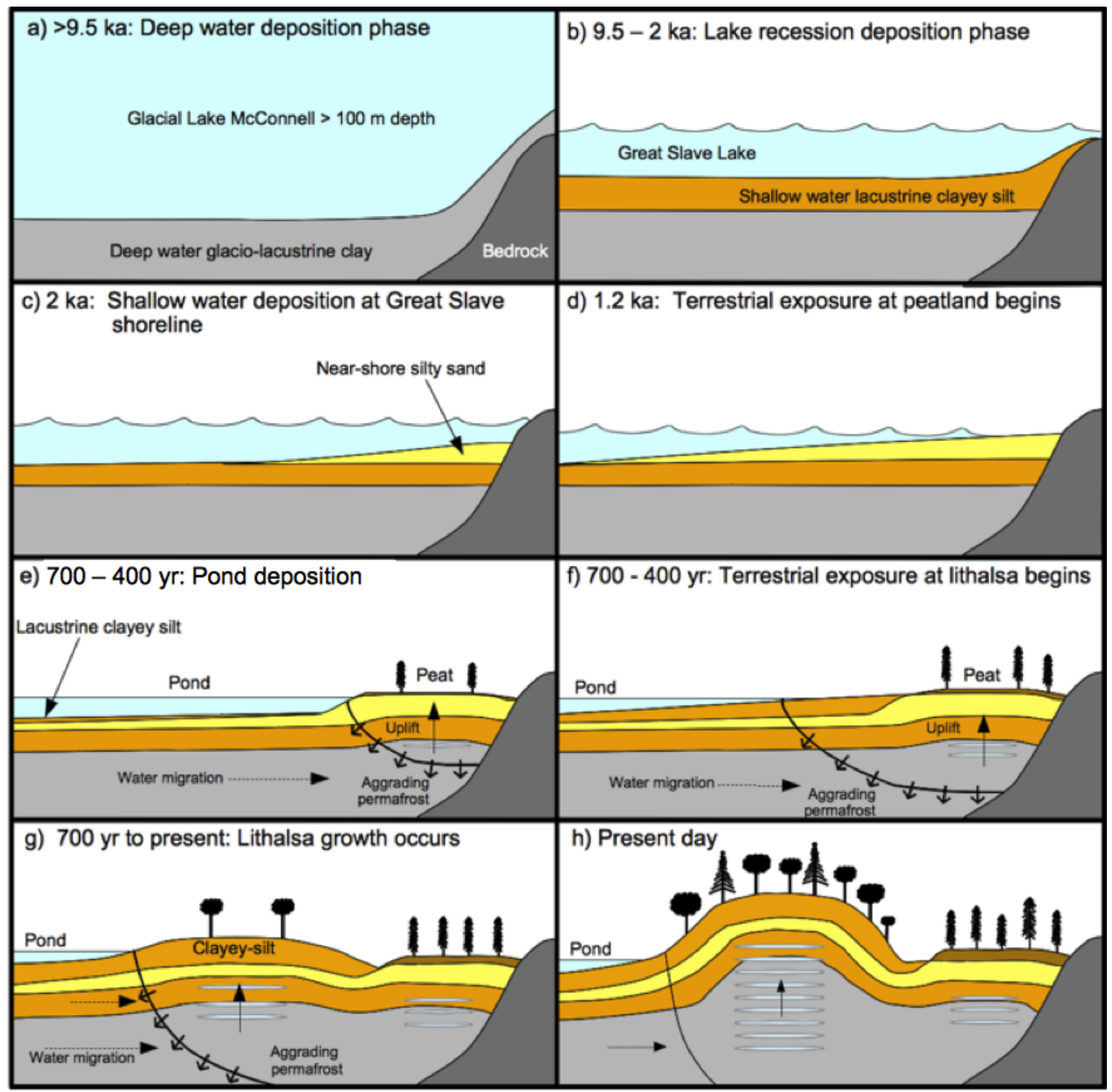

Figure 5.4: Conceptual diagram of the landscape throughout the Holocene at BCSA including a) deep water clay deposition; b) shallow water clayey silt deposition; c) nearshore silty sand deposition over peatland; d) silty sand deposition over lithalsa and terrestrial emergence of peatland; e) lacustrine deposition over lithalsa and permafrost aggradation at peatland; f) continued permafrost aggradation and terrestrial emergence of lithalsa; g) permafrost aggradation and ice segregation under lithalsa; and h) present day conditions. Note: date overlaps occur due to the uncertainty of the exact date for terrestrial emergence at the lithalsa site. 
peat on the mineral surface commenced, and permafrost began to aggrade from the surface-downward (Figure 5.6e). Great Slave Lake recession left a pond in the topographic low next to the emerging peatland, and shallow water lacustrine deposition took place between 700 and $400 \mathrm{yr} \mathrm{BP}$ over what is now the lithalsa. Ice segregation took place in the peatland with the descending freezing front. Water migration from sediments underlying the pond may have contributed to further ice segregation under the peatland, however isotopic results indicate that the waters are largely a reflection of pore water freezing.

Continuing terrestrial emergence eventually led to the exposure of the mineral sediment comprising the present lithalsa some time after $700 \mathrm{yr}$ BP, likely closer to 400 yr BP (Figure 5.6f). As peat continued to form on the surface next to the bedrock outcrop, permafrost aggradation continued downward and into the substrate beneath the newly-forming feature. The pond left on the landscape by Great Slave recession was adjacent to the newly emerged mineral sediment (BCSA pond), and water migration through the newly-formed permafrost began to take place. Once frozen, ice segregation led to the formation of thick ice lenses while slowly desiccating the surrounding finegrained clays and, to an extent, lower clayey silts (Figure 5.6g). Depressions on the surface of the lithalsa formed small pockets for peat accumulation. Terrestrial emergence is indicated by a radiocarbon date of approximately $400 \mathrm{cal}$ BP from one of these isolated depressions, recovered in an interpreted former damp environment with sedges.

At present, the lithalsa has risen $3.7 \mathrm{~m}$ above the adjacent peat surface due to ice segregation occurring at depth (Figure 5.6h). Due to the lines of evidence presented above, the formation process of the lithalsa at BCSA does not support that of Calmels et 
al. (2008) where a former palsa lost its surficial peat cover due to weathering after forming in a flat peatland to become a circular lithalsa. Rather, it appears that the formation process of this lithalsa is similar to the lithalsa in the Akkol Valley (Iwahana et al. 2012) where lake shallowing and microclimatic factors exposed the mineral ground surface, allowing for permafrost aggradation and, over time, frost heave.

\subsection{Broader implications}

\subsubsection{Distribution}

The lithalsa at BCSA is similar to nearly 1800 raised mounds throughout the clayrich Great Slave Lowlands, as well as 40 mounds throughout the clay-poor Great Slave Uplands (Figure 1.3) (Stevens et al. 2012a). These features create a network of mounded terrain, and are not isolated as Harris (1993) proposed.

Based on potential lithalsa distribution (Figure 1.3), it appears the concentration of these features increases towards the shore of Great Slave Lake. This suggests that features have been likely to form following terrestrial emergence as Glacial Lake McConnell and ancestral Great Slave Lake have receded across the landscape. Lithalsas are transient geomorphic features with defined aggradational and degradational stages (Calmels et al. 2008). Since terrestrial emergence and permafrost aggradation likely occurred at the BCSA lithalsa between 700 and $400 \mathrm{yr}$ BP, the features closer to Great Slave Lake may be younger than this and are certainly more prominent on the landscape. It is possible that older features farther from the Great Slave shoreline have already degraded and were not detected by LiDAR, and that the decreased presence of underlying clays at the Uplands, located farther from shore, greatly reduces the presence of lithalsas. Based on the thermal and cryostratigraphic evidence that the lithalsa at BCSA may still 
be growing and permafrost may still be actively aggrading, it is likely that lithalsa growth is continuing across the Great Slave Lowlands. At sites close to the Great Slave shoreline, continued lake recession accompanied by terrestrial exposure and subsequent permafrost aggradation may allow for new lithalsa formation.

Evidence of degraded lithalsas appearing as ringed ramparts (Figure 2.6) on the landscape is indicative of either the transient growth and degradation of lithalsas in the Lowlands being inherently rapid, or that due to the sensitive nature of the characteristically warm permafrost in the Lowlands, microclimatic conditions vary sufficiently to allow both the formation and degradation of lithalsas to occur within the same region within the same time frame.

\subsubsection{Implications for regional infrastructure}

\subsubsection{Thaw subsidence}

The condition of roadways is a major concern in the Canadian Arctic. The thawing of ice-rich terrain can present potential hazards to northern infrastructure (Fortier et al. 2008). One issue along Highway 3 is the persistent subsidence of the road surface and the steepening of embankments due to ground ice at depth. Construction of the 'old' Highway 3 in the 1960 s over a once-larger BCSA lithalsa caused an alteration in the lithalsa's thermal and physical properties (Stevens et al 2012b). Construction of the new highway in the 1990s cut through a section at the eastern tip of the lithalsa (Figure 5.5d). The Geological Survey of Canada noted roadway subsidence of $0.95 \mathrm{~m}$ at BCSA over a 4-5 year period (Figure 5.6) interpreted as the result of permafrost thaw and melting ground ice, with up to $45 \mathrm{~mm}$ of seasonal displacement of the road surface (Stevens et al. 2012b). Roadway subsidence has been significant due to the construction 
a)

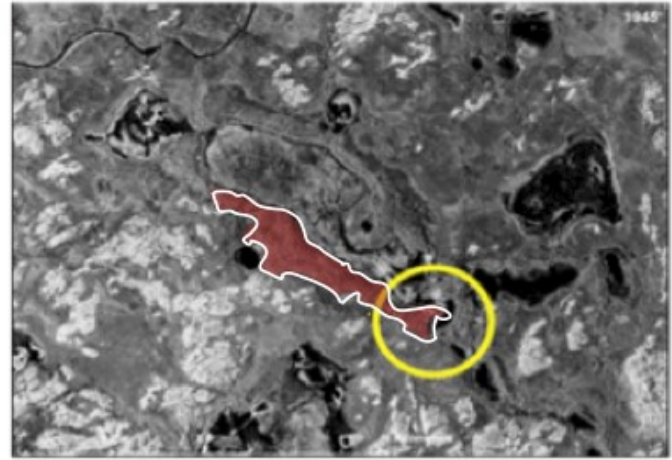

c)

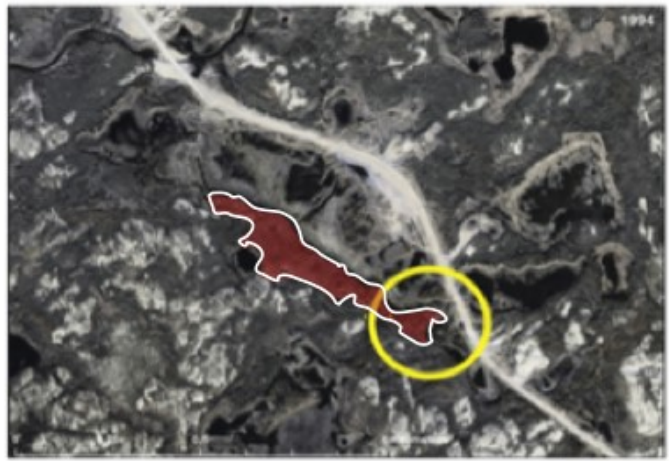

b)

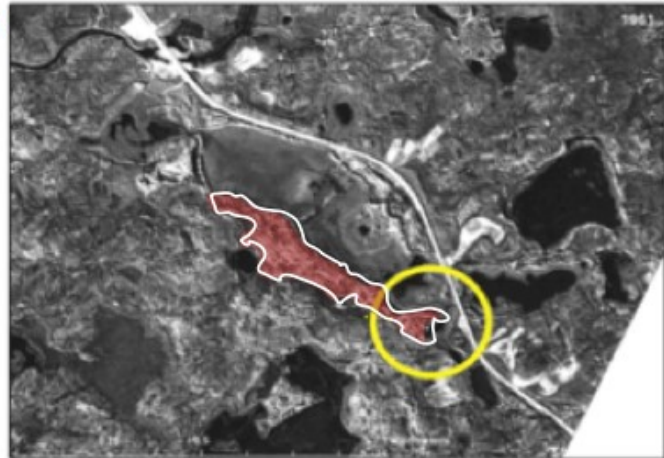

d)

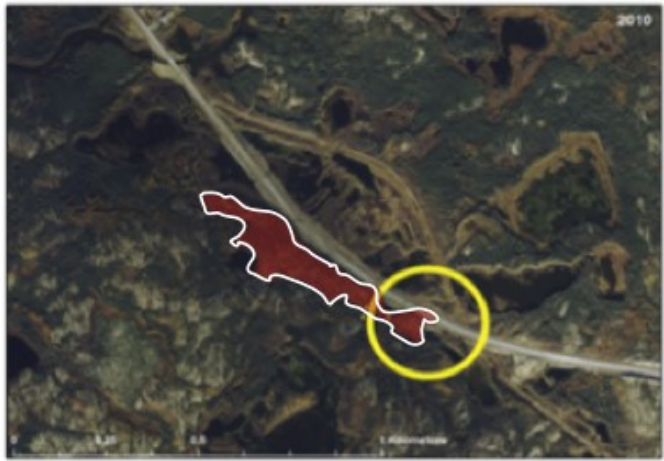

Figure 5.5: Historical air photos of the BCSA study site at a) 1945; b) 1961; c) 1994; and d) 2010; with the BCSA lithalsa outlined. The section of lithalsa eventually cut through by new Highway 3 is circled. 


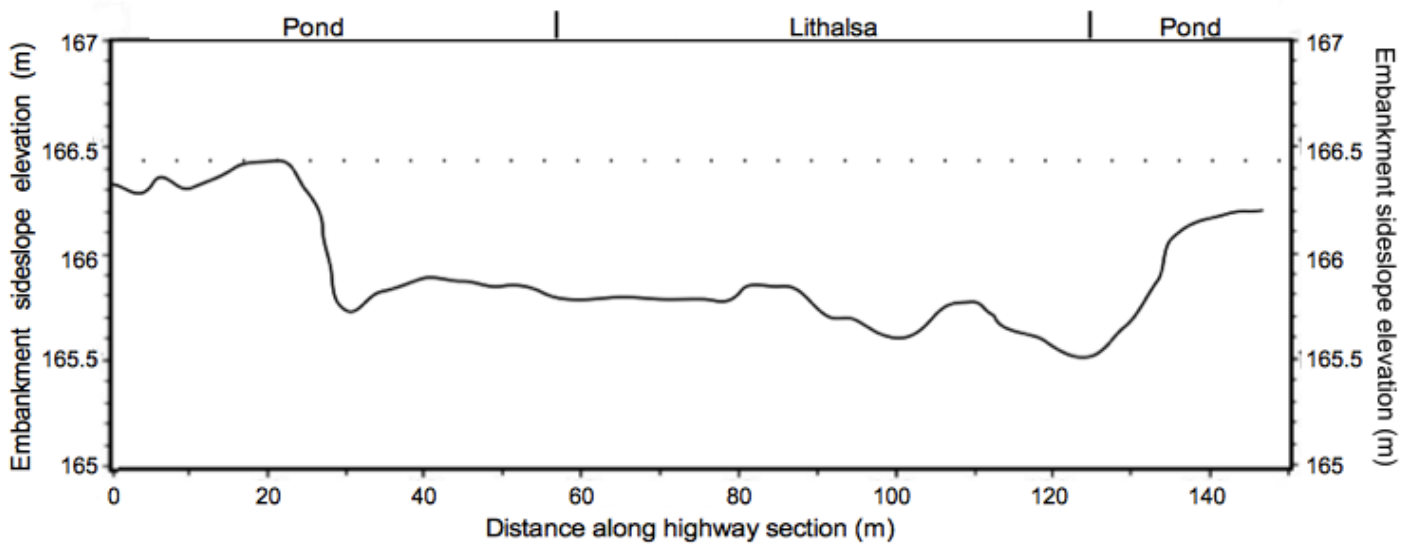

Figure 5.6: $150 \mathrm{~m}$ section along Highway 3 at BCSA, illustrating a $0.95 \mathrm{~m}$ subsidence of the highway right-of-way where the roadway was built through the lithalsa (adapted from Stevens et al. 2012b). 
method of removing the first $4 \mathrm{~m}$ of ice-poor material at the lithalsa, and building the road surface closer to the ice-rich lower clayey silts and clays.

To further illustrate the severity of thaw subsidence at BCSA, Figure 5.7 demonstrates the amount that can potentially occur at the peak of the lithalsa $(\mathrm{BH} 04 \mathrm{a}+\mathrm{b})$ when all ice lenses have been melted in the event of thaw or active-layer deepening at depths up to the termination of drilling depth. This model assumes the sediment surrounding the ice is at saturation and no melted lens water is re-absorbed into sediment. Hysteresis is not accounted for. The ice content is based on the cumulative ice lens thickness per $0.5 \mathrm{~m}$ section of core (Table 4.2).

At $\mathrm{BH} 04$, the first $3.80 \mathrm{~m}$ of substrate contains little ground ice, resulting in minor subsidence. After $3.80 \mathrm{~m}$ of downward thawing, approximately $0.35 \mathrm{~m}$ of subsidence occurs. However, after the first $3.80 \mathrm{~m}$ of ice-poor material has thawed, subsidence occurs rapidly, to a total of $2.17 \mathrm{~m}$ at the base of the borehole. Because this theoretical total was reached within the first $8.4 \mathrm{~m}$ (Figure. 4.11), additional subsidence may continue under Highway 3 at BCSA if the ground under the highway blast rock is similar to that in the adjacent lithalsa.

\subsubsection{Thaw strain}

Thaw strain represents the proportion of total sample volume in excess of soil porosity (Morse et al. 2009). The thaw strain $(\delta)$ of BH04 was calculated using:

$$
\delta=\left[\left(\rho_{t}-\rho_{f}\right) / \rho_{t}\right]
$$

where $\rho_{t}$ and $\rho_{f}$ are the respective thawed and frozen bulk densities.

The maximum frozen bulk density of a sediment sample at BCSA was $2.10 \mathrm{~g} \mathrm{~cm}^{-3}$, and represents the maximum extent at which soil may consolidate (overlying 


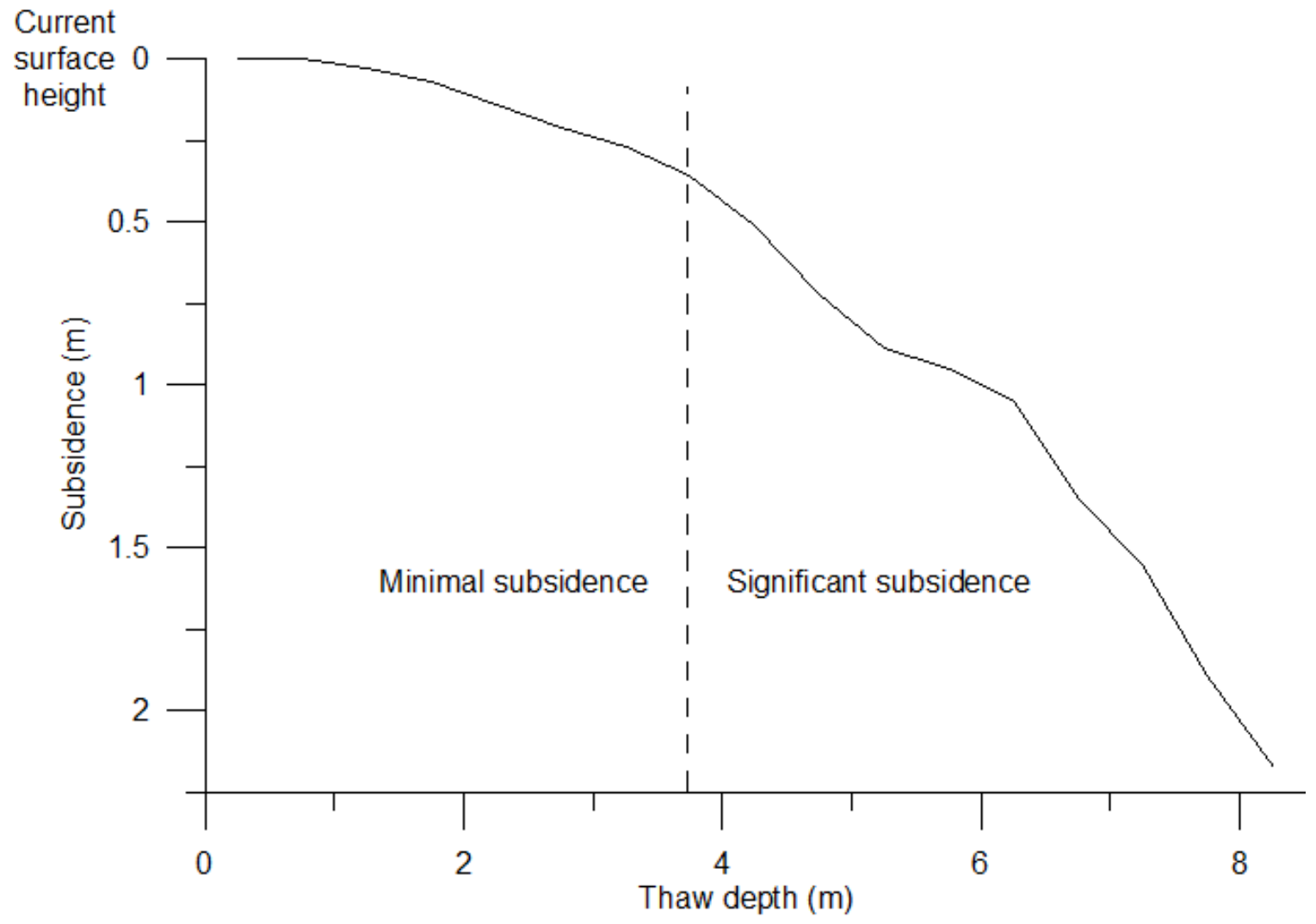

Figure 5.7 Thaw subsidence with a deepening active layer at BHO4 $(a+b)$. 
sediment load is discounted in this calculation). The $\rho$ of $2.10 \mathrm{~g} \mathrm{~cm}^{-3}$ was not modified for use as $\rho_{t}$ because the sample was so consolidated that its bulk density did not change between the frozen and thawed state. Figure 5.8 represents the thaw strain at $\mathrm{BH} 04$. The thaw strain variation increases with depth as low $\rho$ ice-rich clay, and stiff high $\rho$ clays alternate at depth. Maximum thaw strains exceeded 0.5 at depth, indicating that the amount of thermokarst subsidence is greater than the increase in active layer thickness at some areas (Morse et al. 2009).

\subsection{Summary}

This chapter has provided discussion confirming the geomorphic classification of the frost mound at BCSA as a lithalsa. It has also demonstrated that the lithalsa is a young feature on the landscape, as permafrost aggradation within the lithalsa began approximately $400 \mathrm{yr}$ BP. The layered ice core observed within the lithalsa was formed by ice segregation, and is responsible for, at a minimum, $54 \%$ of its topographical relief. Water within the substrate at BCSA is likely highly mobile and permafrost may be continuing to aggrade. The primary water sources for ice lens formation appear to be the BCSA pond, rainwater, and, to a lesser degree, snow. Thawing of the lithalsa could lead to at least $2.17 \mathrm{~m}$ of subsidence. 


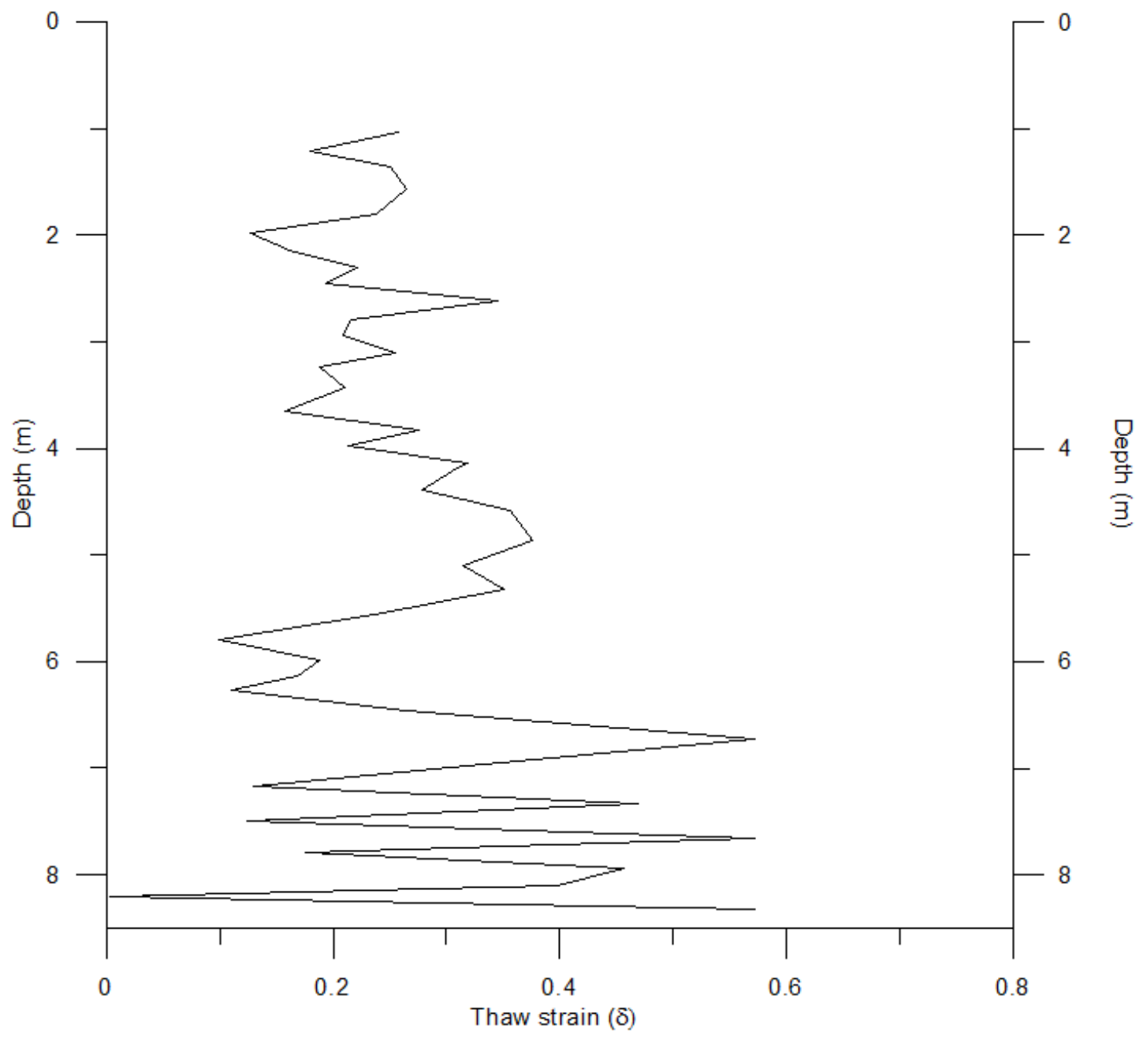

Figure 5.8: Thaw strain for BH04 $(a+b)$ using a frozen bulk density of $2.10 \mathrm{~g} \mathrm{~cm}^{-3}$. 


\section{Chapter 6 Conclusions}

This thesis evaluated the geomorphic origins of a raised feature in the widespread discontinuous permafrost zone of the Great Slave Lowlands west of Yellowknife, Northwest Territories. In the last three years, the recognition of these features in the landscape has prompted questions regarding their internal composition and development. Fieldwork at the Boundary Creek Study Area has resulted in the following responses to the main research hypotheses:

1) The permafrost feature at BCSA contains an icy core. This was verified with deep borehole drilling to $8.4 \mathrm{~m}$, which revealed relatively ice-poor conditions within the first $4 \mathrm{~m}$ of substrate, and a substantial increase in ice content at greater depth within the underlying fine-grained clays. Ice lenses on the order of $0.1 \mathrm{~m}$ thick may have formed due to ice segregation in the "warm" permafrost at BCSA. The ice lenses at depth appeared layered between dense clayey sediment.

2) The frost mound is categorized as a lithalsa, meeting the three main criteria for lithalsa formation: a warm ground thermal regime to support water migration to ice lenses, an abundant water supply to feed the ice lenses via cryosuction, and the presence of finegrained sediment, promoting ice segregation and high unfrozen water contents at depth. Minimal sandy sediments, a lack of extensive drained lakes, and a comparatively warmer ground and air temperatures discount the possibility of a closed-system Mackenzie Delta-like pingo. The lack of continuous peat cover is not indicative of a palsa and, due to no quantifiable seasonal physical change, the feature is not a seasonal frost mound. 
3) It is probable that the presence of deep-seated ground ice is responsible for the lithalsa's raised topography. Stratigraphic records at BCSA indicate that the sequence of clays, lower clayey silts, silty sands and upper clayey silts are domed, sub parallel with the surficial relief, whereas the same layers were observed horizontally beneath the adjacent peatland. Tilted ice lenses suggest the displacement or heave of substrate after the lenses had formed horizontally. The differential heave of the clayey silt to clay sediment boundary is approximately $2.8 \mathrm{~m}$ between the lithalsa and adjacent peatland.

4) The lithalsa formed after deglaciation of the Great Slave Lowlands and is composed of post-glacial water sources. The $\delta^{18} \mathrm{O}$ values between -18.4 and $-16.6 \%$ from ice lenses at 4.0 to $8.4 \mathrm{~m}$ depth indicate that the ice-based core likely formed primarily from modern meteoric water sources. Detrital organics from sediments below the peatland date to between 1570 and 1770 cal BP, indicating near-shore silty sand deposition at that time, and a date of about 1240 cal BP from the base of the peat deposits suggests approximate timing of terrestrial emergence and permafrost aggradation at the peatland site. A sample age of approximately $700 \mathrm{yr}$ BP collected under $2 \mathrm{~m}$ of sediment within the lithalsa, as well as a sample age of $400 \mathrm{yr}$ BP from an organic sample recovered under a small peat pocket on the lithalsa, indicates that terrestrial emergence (and permafrost aggradation) occurred between these times, approximately 500 to 800 years after emergence at the peatland site. Thus, permafrost aggradation accompanied by ice segregation within the lithalsa was initiated within the last 700 years, and likely closer to 400 years. The primary groundwater source for ice 
segregation was likely a talik associated with a pond flanking the north side of the lithalsa. Evidence of the lithalsa's incipient nature includes clays, some highly plastic and unfrozen, with high unfrozen water contents between ice lenses at depths below 7 $\mathrm{m}$, suggesting that movement of unfrozen water toward the ice-based core by cryosuction may still be occurring.

Although this study examined a single lithalsa, there are nearly 1800 similar raised mounds mapped in the area (Stevens et al. 2012a), indicating the potential for a much larger amount of ice-rich terrain across the landscape than previously recognized. The results of this thesis may be extrapolated across the region with regard to the internal composition and geomorphic history of the feature, but caution must be exercised when extrapolating the data without further ground validation.

Understanding the morphology of lithalsas in the Lowlands, starting with BCSA, is important for future landscape predictability and infrastructure planning in the region. Engineers and planners as well as road crews can better comprehend the ice-rich nature of a lithalsa's internal composition and plan accordingly to either avoid lithalsas or mitigate future subsidence. The locations of potential lithalsas and the new information presented here regarding their internal composition and morphology should have a positive effect for future northern infrastructure expansion and maintenance.

Future research at BCSA could include a deeper borehole extending to bedrock at the lithalsa to determine if the remaining unexplained relief can be accounted for by deep-seated ground ice. Further research on lithalsas within the Lowlands would include deep drilling of multiple lithalsas in the region to confirm similar geomorphic origins and internal compositions. Continued monitoring of roadway subsidence at BCSA will be 
key to understanding the long-term highway subsidence issues related to construction over lithalsas and other ice-rich terrain. 


\section{References}

Aden, A. 2014. Physical properties, mineralogy and sediment texture of a glaciolacustrine clay in the Great Slave Lowland, Northwest Territories, Canada. Undergraduate Thesis, Dept. of Environmental Science, Carleton University, Ottawa, Canada.

Åhman, R. 1977. Palsar I Nordnorge (Summary: Palsas in Northern Norway). Meddelanden fran Lunds Universitet Geografiska Institution, 78, 196 pp.

Allard, M., Caron, S. Begin, Y. 1996. Climatic and ecological controls on ice segregation and thermokarst: the case history of a permafrost plateau in northern Quebec. Permafrost and Periglacial Processes, 7, 207-227.

An, W., Allard, M. 2005. A mathematical approach to modeling palsa formation insights on processes and growth conditions. Cold Regions Science and Technology, 23, 231-244.

Aspler, L.B. 1978. Surficial geology, permafrost and related engineering problems, Yellowknife area, part of 85 J/8. NWT Geoscience office, EGS Open File 1978-08.

Bennett, M.R., Doyle, P., Mather, A.E. 1996. Dropstones: their origin and significance. Paleogeography, Paleoclimatology, Paleoecology, 121, 331-339.

Brown, R.J.E. 1973. Influence of climatic and terrain factors on ground temperature at three locations in the permafrost region of Canada. Proceedings of the Second International Conference on Permafrost, Yakutsk, USSR, North American contribution. National Academy of Science, Washington, D.C., pp. 27-34.

Burn, C.R. 1986. On the origin of aggradational ice in permafrost. Ph.D. Thesis, Carleton University, Ottawa, Canada.

Burn, C.R. 2004. The thermal regime of cryosols. In Cryosols: Permafrost-affected Soils. Edited by J.M. Kimble. Springer-Verlag, Berlin, Germany, pp. 391-413.

Burt, T.P., Williams, P.J. 1976. Hydraulic conductivity in frozen soils. Earth Surface Processes and Landforms, 1, 349-360.

Calmels, F., and Allard, M. 2008. Segregated ice structures in various heaved permafrost landforms through CT scan. Earth Surface Processes and Landforms, 33, 209-225.

Calmels, F., Allard, M., Delisle, G. 2008. Development and decay of a lithalsa in Northern Quebec: A geomorphological history. Geomorphology, 97, 287-299.

Clegg, B.F., Clarke, G.H., Chipman, M.L., Chou, M., Walker, I.R., Tinner, W., Hu, F.S. 2010. Six millennia of summer temperature variation based on midge analysis of 
lake sediments from Alaska. Quaternary Science Review, 29, 3308-3510.

Delisle, G, Allard, M, Fortier, R., Calmels, F., Larrivée, É. 2003. Umiujaq, northern Québec: Innovative techniques to monitor the decay of a lithalsa in response to climate change. Permafrost and Periglacial Processes, 14, 375-385.

Dionne, J-C. 1978. Formes et phénomènes périglaciaires en Jamésie, Québec subarctique. Géographie physique et Quaternaire, 32, 187-247.

Dionne, J.C. 1984. Palses et limite méridionale du pergélisol dans l'hémisphère nord; le cas de Blanc-Sablon, Québec. Géographie physique et Quaternaire, 38, 16584.

Douglas, M., Clark, I.D., Raven, K., Bottomley, D. 2000. Groundwater mixing dynamics at a Canadian Shield mine. Journal of Hydrology, 235, 88-103.

Dyke, A.S., Moore, A.J., Robertson, L. 2003. Deglaciation of North America. Geological Survey of Canada, Ottawa. Open File 1574.

Ecosystem Classification Group 2008. Ecological Regions on the Northwest Territories - Taiga Shield. Department of Environment and Natural Resources, Government of the Northwest Territories, Yellowknife, NT, Canada. Viii + 146 pp. + insert map.

Environment Canada 2012. Climate Normals and Averages 1971-2000. Online data at http://climate.weatheroffice.gc.ca/climate_normals/index_e.html

Fortier, R., Aubé-Maurice, B. 2008. Fast Permafrost Degradation near Umiujaq in Nunavik (Canada) since 1957 assessed from the time-lapse aerial and satellite photographs. In: Proceedings of the 9th International Conference on Permafrost, Fairbanks, Alaska, 29 June - 3 July 2008. Edited by D.L. Kane and K.M. Hinkel. Institute of Northern Engineering, University of Alaska Fairbanks, Fairbanks, Alaska. Vol. 1, pp. 457-462.

Fortier, R., Bolduc, M. 2008. Thaw Settlement of Degrading Permafrost: a Geohazard Affecting the Performance of Man-Made Infrastructures at Umiujaq in Nunavik (Québec). In: Proceedings of the 4th Canadian Conference on Geohazards: From Causes to Management. Edited by J. Locat, D. Perret, D. Turmel, D. Demers and S. Leroueil. Presse de l'Université Laval, Québec, pp. 279-286.

Fortier, R., LeBlanc, A-M., Allard, M., Buteau, S., Calmels, F. 2008. Internal structure and conditions of permafrost mounds at Umiujac in Nunavik, Canada, inferred from field investigations and electrical resistivity tomography. Canadian Journal of Earth Sciences, 45, 368-387. 
Fries, T., Bergström, E. 1910. Några iakttagelser öfver palsar och deras förekomst inordligaste Sverige. Geologiska Foreningens, Stockholm Forhandlinger, 32, 195-205.

Gibson, J.J., Reid, R. 2010. Stable isotope fingerprint of open-water evaporation losses and effective drainage are fluctuations in a subarctic shield watershed. Journal of Hydrology, 381, 142-150.

Harris, S.A. 1993. Palsa-like mounds developed in a mineral substrate, Fox Lake, Yukon Territory. In: Proceedings of the Sixth International Conference on Permafrost, Beijing, China. South China Univ. of Technology Press, Vol. 1, pp. 248-253.

Heginbottom, J.A., Dubreuil, M.A., Harker, P.A. (1995). Canada - Permafrost, in: National Atlas of Canada, 5th Edition, National Atlas Information Service, Natural Resources Canada, MCR 4177.

Hoeve, T.E., Seto, J.T.C. and Hayley, D.W. 2004. Permafrost response following reconstruction of the Yellowknife Highway. In: Proceedings of the Cold Regions Engineering and Construction Conference, Edmonton, Alberta.

Iwahana, G., Fukui, K., Makhailov, N., Ostanin, O., and Fujii, Y. 2012. Internal structure of a lithalsa in the Akkol Valley, Russian Altai Mountains. Permafrost and Periglacial Processes, 23, 107-118.

Karunaratne, K.C., Kokelj, S.V., Burn, C.R. 2008. Near-surface permafrost conditions near Yellowknife, Northwest Territories, Canada. In: Proceedings of the Ninth International Conference on Permafrost, Fairbanks, Alaska, 29 June - 3 July 2008. Edited by D.L. Kane and K.M. Hinkel. Institute of Northern Engineering, University of Alaska Fairbanks, Fairbanks, Alaska. Vol. 1, pp. 907-912.

Kerr, D. E. and Wilson, P. 2000. Preliminary surficial geology studies and mineral exploration considerations in the Yellowknife area, Northwest Territories; Geological Survey of Canada, Current Research 2000-C3, 8 pp.

Kokelj, S.V. and Burn, C.R. 2003. Ground ice and soluble cations in near-surface permafrost, Inuvik, Northwest Territories, Canada. Permafrost and Periglacial Processes, 14, 275-289.

Kokelj, S.V., and Burn, C.R. 2005. Geochemistry of the active layer and near-surface permafrost, Mackenzie Delta region, Northwest Territories, Canada. Canadian Journal of Earth Sciences, 42, 37-48.

Konrad, J.M., McCammon, A.W. 1990. Solute partitioning in freezing soils. Canadian Geotechnical Journal, 27, 726-736. 
Konrad, J., Morgenstern, N.R. 1980. A mechanistic theory of ice lens formation in finegrained soils. Canadian Geotechnical Journal, 17, 473-486.

Lemmen, D.S., Duk-Rodkin, A., and Bednarski, J.M. 1994. Late glacial drainage systems along the northwestern margin of the Laurentide Ice Sheet. Quaternary Science Reviews, 13, 805-828.

Mann, M.E., Zhang, Z., Rutherford, S., Bradley, R.S., Hughes, M.K., Shindell, D., Ammann, C., Faluvegi, G., Ni, F. 2009. Global signatures and dynamic origins of the Little Ice Age and Medieval Climate Anomaly. Science, 326, 1256-1260.

Matthews, JA., Dahl, S-O., Berrisford, M.S., Nesje, A. 1997. Cyclic development and thermokarstic degradation of palsas in the mid-Alpine zone at Leirpullan, Dovrefjell, southern Norway. Permafrost and Periglacial Processes, 8, 107122.

Michel, F.A. 2011. Isotope characterization of ground ice in northern Canada. Permafrost and Periglacial Processes, 22, 3-12.

Morse, P.D., Burn, C.R., Kokelj, S.V. 2009. Near-surface ground ice distribution, Kendall Island Bird Sanctuary. Permafrost and Periglacial Processes, 20, 155-171.

Mackay, J.R. 1985. Pingo ice of the western Arctic coast, Canada. Canadian Journal of Earth Sciences, 22, 1452-1464.

Mackay, J.R. 1998. Pingo growth and collapse, Tuktoyaktuk Peninsula area, western Arctic coast, Canada: a long-term field study. Géographie physique et Quaternaire 52, 271-323.

Miller, R.D. 1972. Freezing and heaving of saturated and unsaturated soils. Highway Research Record, 393, 1-11.

Moorman, B.J., Michel, F.A., Drimmie, R.J. 1996. Isotope variability in Arctic precipitation as a climatic indicator. Geoscience Canada, 23, 189-194.

Murton, J.B. and French, H.M. 1994. Cryostructures in Permafrost, Tuktoyaktuk coastlands, western Arctic Canada. Canadian Journal of Earth Sciences, 31, 737747.

Oldenborger, G. A. 2012. Electrical Resistivity Surveys for Permafrost Terrain Characterization along the Highway 3 Corridor, Yellowknife, N.W.T. Geological Survey of Canada, Open File 7062.

O'Neill, H.B. 2011. The development of near-surface ground ice at Illisarvik, Richards Island, Northwest Territories. Master's thesis, Dept. of Geography and Environmental Studies, Carleton University, Ottawa, Canada. 
O'Neill, H.B., Burn, C.R. 2012. Physical and temporal factors controlling the development of near-surface ground ice at Illisarvik, western Arctic coast, Canada. Canadian Journal of Earth Sciences, 49, 1096-1110.

Osterkamp, T. E., Burn, C.R. 2003. Permafrost, in Encyclopedia of Atmospheric Sciences, edited by J. R. Holton, pp. 1717-1729, Academic, Oxford, U.K.

Pissart, A. 2000. Remnants of lithalsas of the Hautes Fagnes, Belgium: a summary of present-day knowledge. Permafrost and Periglacial Processes 2, 325-355.

Pissart, A. 2002. Palsas, lithalsas and remnants of these periglacial mounds. A progress report. Progress in Physical Geography, 26, 605-621.

Pissart, A. 2003. The remnants of Younger Dryas lithalsas on the Hautes Fagnes plateau in Belgium and elsewhere in the world. Geomorphology, 52, 5-38.

Pissart, A. 2010. The side growth of lithalsas: some comments on observations in Northern Quebec. Permafrost and Periglacial Processes, 21, 362-365.

Pissart, A., Calmels, F., and Wastiaux, C. 2011. The potential lateral growth of lithalsas. Quaternary Research, 75, 371-377.

Pollard, W.H. 2008. Seasonal frost mounds. The Canadian Geographer, 35, 214-218.

Seppälä, M. 1972. The term 'palsa'. Zeitschrift fur Geomorphologie N.F. 16:463.

Seppälä, M., 1979. Recent palsa studies in Finland. Acta Universitatis Ouluensis, 82A, 81-87.

Seppälä, M. 1982. An experimental study on the formation of palsas. In: Proceedings of the Fouth Canadian Permafrost Conference, Calgary. National Research Council of Canada, Ottawa. pp. 36-42.

Seppälä, M. 1986. The origin of palsas. Geografiska Annaler, 68A, 141-147.

Seppälä, M., 1988. Palsas and related forms. In: Clark, M.J. (ed.) Advances in periglacial geomorphology. 247-278. John Wiley, Chichester.

Seppälä, M. 2006. Palsa mires in Finland. The Finnish Environment, 23, 155-162.

Seto, J.T.C., Arenson, L.U., and Cousineau, G. 2012. Vulnerability to climate change assessment for a highway constructed on permafrost. In Proceedings Cold Regions Engineering 2012: Sustainable Infrastructure Development in a Changing Cold Environment. American Society of Civil Engineers, pp. 515-524. 
Shepard, F. P. 1954. Nomenclature based on sand-silt-clay ratios. Journal of Sedimentary Petrology, 24, 151-158.

Smith, D.G. 1994. Glacial Lake McConnell paleogeography, age, duration, and associate river deltas, Mackenzie River Basin, western Canada. Quaternary Science Reviews, 13, 829-843.

Smith, M. W. and Riseborough, D. W. (2002), Climate and the limits of permafrost: a zonal analysis. Permafrost and Periglacial Processes, 13, 1-15.

Stevens, C.W., Wolfe, S.A., Gaanderse, A.J.R. 2012a. Lithalsa distribution, morphology and landscape associations in the Great Slave Lowlands, Northwest Territories. Geological Survey of Canada, Open File 7255.

Stevens, C.W., Short, N., Wolfe, S.A. 2012b. Seasonal surface displacement and highway embankment grade derived from InSAR and LiDAR, Highway 3 west of Yellowknife, Northwest Territories. Geological Survey of Canada, Open File 7087.

Upiter, L.M., Vermaire, J.C., Patterson, R.T., Crann, C.A., Galloway, J.M., Macuber, A.L., Neville, L.A., Swindles, G.T., Falck, H., Roe, H.M., Pisaric, M.F.J. 2014. Middle to late Holocene chironomid-inferred July temperatures for the central Northwest Territories, Canada. Journal of Paleolimnology, 52, 11-26.

Vallée, S., Payette, S. 2007. Collapse of permafrost mounds along a subarctic river over the last 100 years (northern Quebec). Geomorphology, 90, 162-170.

Vanderburgh, S., and Smith, D.G. 1988. Slave River delta: geomorphology, sedimentology, and Holocene reconstruction. Canadian Journal of Earth Sciences, 25, 1990-2004. doi: 10.1139/e88-186

van Everdingen, R., ed. 1998 revised May 2005. Multi-language glossary of permafrost and related ground-ice terms. Boulder, CO. National Snow and Ice Data Center.

Washburn, A.L. 1979. Geocryology. A survey of periglacial processes and environments. Arnold, London. 406 p.

Washburn, A.L. 1983 What is a palsa? Abhandlungen der Akademie der Wissenschaften im Göttingen. Mathematisch-Physikalische Klasse Dritte Folge, 35, 34-47.

Westin, B., Zuidhoff, F.S. 2001. Ground thermal conditions in a frost-crack polygon, a plasa and a mineral palsa (lithalsa) in the discontinuous permafrost zone, northern Sweden. Permafrost and Periglacial Processes, 12, 325-335. 
Williams, P.J., Smith, M.W. 1989. The Frozen Earth; Fundamentals of Geocryology. Cambridge University Press, New York, USA.

Wolfe, S.A. (ed.) 1998. Living with frozen ground - A field guide to permafrost in Yellowknife. Geological Survey of Canada, Miscellaneous Report 64.

Wolfe, S.A., Duchesne, C., Gaanderse, A.J., Houben, A.J., D’Onofrio, R.E., Kokelj, S.V., Stevens, C.W. 2011. Report on 2010-2011 permafrost investigations in the Yellowknife area, Northwest Territories. Geological Survey of Canada, Open File 6983.

Wolfe, S.A., Stevens, C.W., Gaanderse, A.J., Oldenborger, G.A. 2014. Lithalsa distribution, morphology and landscape associations in the Great Slave Lowlands, Northwest Territories, Canada. Geomorphology, 204, 302-313.

Wünnemann, B. Reinhardt, C., Kotlia, B.S., Riedel, F. 2008. Observations on the relationship between lake formation, permafrost activity and lithalsa development during the last 2000 years in the Tso Kar Basin, Ladakh, India. Permafrost and Periglacial Processes, 19, 341-358.

Zuidhoff, F.S., Kolstrup, E. 2000. Changes in palsa distribution in relation to climate change in Laivadalen, Northern Sweden, especially 1960-1997. Permafrost and Periglacial Processes, 11, 55-69. 


\section{Appendices}

Appendix A: Table of wet gravimetric moisture contents with depth from all deep boreholes at BCSA.

\begin{tabular}{|c|c|c|c|c|c|c|c|c|c|}
\hline \multicolumn{2}{|c|}{ ВH01 } & \multicolumn{2}{|c|}{ ВН02 } & \multicolumn{2}{|c|}{ ВH03 } & \multicolumn{2}{|c|}{ ВН04 } & \multicolumn{2}{|c|}{ BH05 } \\
\hline $\begin{array}{c}\text { Depth } \\
\text { (m) }\end{array}$ & $\begin{array}{l}\text { MC } \\
(\%) \\
\end{array}$ & $\begin{array}{c}\text { Depth } \\
\text { (m) }\end{array}$ & $\begin{array}{l}\text { MC } \\
(\%) \\
\end{array}$ & $\begin{array}{c}\text { Depth } \\
\text { (m) }\end{array}$ & $\begin{array}{l}\text { MC } \\
(\%)\end{array}$ & $\begin{array}{c}\text { Depth } \\
\text { (m) }\end{array}$ & $\begin{array}{l}\text { MC } \\
(\%)\end{array}$ & $\begin{array}{c}\text { Depth } \\
\text { (m) }\end{array}$ & $\begin{array}{l}\text { MC } \\
(\%)\end{array}$ \\
\hline 0.30 & 86.6 & 0.21 & 20.7 & 0.13 & 24.4 & 0.13 & 26.8 & 0.18 & 43.4 \\
\hline 0.45 & 83.2 & 0.44 & 25.7 & 0.38 & 21.6 & 0.28 & 35.9 & 0.23 & 18.5 \\
\hline 0.71 & 86.3 & 0.62 & 40.3 & 0.53 & 18.6 & 0.57 & 32.2 & 0.38 & 19.0 \\
\hline 0.85 & 73.8 & 0.85 & 32.8 & 0.69 & 17.0 & 0.71 & 23.0 & 0.53 & 20.2 \\
\hline 0.94 & 38.3 & 0.97 & 20.6 & 0.84 & 19.2 & 0.81 & 25.1 & 0.73 & 16.5 \\
\hline 1.20 & 21.4 & 1.16 & 21.2 & 1.00 & 22.3 & 0.95 & 24.0 & 1.03 & 21.6 \\
\hline 1.60 & 23.7 & 1.46 & 33.7 & 1.26 & 22.7 & 1.12 & 27.1 & 1.28 & 23.5 \\
\hline 2.01 & 20.7 & 1.63 & 31.2 & 1.38 & 19.9 & 1.30 & 29.8 & 1.39 & 24.4 \\
\hline 2.28 & 22.0 & 1.77 & 33.5 & 1.51 & 21.5 & 1.45 & 31.5 & 1.60 & 34.7 \\
\hline 2.66 & 19.4 & 1.95 & 25.7 & 1.63 & 31.3 & 1.68 & 24.1 & 1.82 & 38.2 \\
\hline 2.94 & 23.5 & 2.15 & 24.8 & 1.83 & 25.9 & 1.92 & 29.8 & 1.95 & 27.4 \\
\hline 3.12 & 17.0 & 2.39 & 27.6 & 2.02 & 26.6 & 2.04 & 30.1 & 2.19 & 34.7 \\
\hline 3.40 & 25.6 & 2.64 & 28.6 & 2.19 & 30.1 & 2.24 & 30.9 & 2.24 & 27.1 \\
\hline 3.77 & 25.9 & 2.89 & 21.7 & 2.36 & 35.9 & 2.37 & 37.3 & 2.43 & 28.6 \\
\hline 4.34 & 28.9 & 3.12 & 22.4 & 2.54 & 24.7 & 2.53 & 29.7 & 2.63 & 24.3 \\
\hline 4.61 & 35.3 & 3.29 & 28.5 & 2.72 & 24.4 & 2.70 & 24.1 & 2.83 & 28.4 \\
\hline 4.67 & 33.7 & 3.52 & 24.4 & 2.98 & 19.7 & 2.87 & 32.1 & 3.00 & 25.4 \\
\hline- & - & 3.97 & 39.4 & 3.18 & 25.6 & 3.02 & 24.8 & 3.05 & 26.2 \\
\hline- & - & 4.12 & 27.2 & 3.37 & 25.2 & 3.18 & 21.6 & 3.28 & 39.3 \\
\hline- & - & 4.34 & 20.3 & 3.50 & 30.8 & 3.32 & 24.1 & 3.54 & 40.7 \\
\hline - & - & 4.60 & 26.1 & 3.69 & 39.6 & 3.55 & 29.7 & 3.78 & 38.2 \\
\hline- & - & 4.80 & 34.0 & 3.93 & 32.9 & 3.75 & 23.8 & 3.92 & 25.4 \\
\hline- & - & 4.95 & 36.8 & 4.09 & 43.0 & 3.91 & 34.8 & 4.03 & 27.8 \\
\hline- & - & 5.26 & 27.9 & 4.28 & 32.2 & 4.02 & 38.0 & 4.27 & 50.3 \\
\hline- & - & 5.53 & 35.2 & 4.44 & 20.9 & 4.12 & 33.7 & 2.44 & 23.4 \\
\hline - & - & 5.64 & 65.5 & 4.58 & 18.9 & 4.33 & 39.0 & 4.62 & 36.3 \\
\hline - & - & 5.80 & 26.5 & 4.74 & 20.1 & 4.47 & 33.0 & 4.97 & 31.1 \\
\hline - & - & - & - & 4.89 & 27.0 & 4.74 & 29.5 & 5.11 & 19.8 \\
\hline- & - & - & - & 5.02 & 51.8 & 5.00 & 79.6 & 5.41 & 41.9 \\
\hline- & - & - & - & 5.18 & 38.2 & 5.22 & 34.8 & 5.58 & 39.8 \\
\hline - & - & - & - & 5.37 & 29.2 & 5.44 & 41.5 & 5.95 & 41.0 \\
\hline - & - & - & - & 5.53 & 32.0 & 5.69 & 29.6 & 6.03 & 41.9 \\
\hline - & - & - & - & 5.72 & 34.2 & 5.95 & 25.9 & 6.26 & 54.6 \\
\hline- & - & - & - & 5.88 & 44.6 & 6.06 & 33.1 & 6.43 & 61.4 \\
\hline
\end{tabular}




\begin{tabular}{|cc|cc|cc|cc|cc|}
\hline \multicolumn{2}{|c|}{ BH01 } & \multicolumn{2}{c|}{ BH02 } & \multicolumn{2}{c|}{ BH03 } & \multicolumn{2}{c|}{ BH04 } & \multicolumn{2}{c|}{ BH05 } \\
Depth & MC & Depth & MC & Depth & MC & Depth & MC & Depth & MC \\
\hline (\%) & (m) & $(\%)$ & (m) & (\%) & (m) & (\%) & (m) & (\%) \\
\hline- & - & - & - & 6.05 & 25.0 & 6.22 & 34.2 & 6.71 & 42.6 \\
- & - & - & - & 6.30 & 43.6 & 6.34 & 64.1 & 6.78 & 38.3 \\
- & - & - & - & 6.43 & 33.9 & 6.64 & 57.8 & 7.24 & 31.2 \\
- & - & - & - & 6.65 & 75.3 & 6.85 & 44.9 & - & - \\
- & - & - & - & 6.88 & 93.5 & 7.10 & 30.2 & - & - \\
- & - & - & - & - & - & 7.28 & 34.7 & - & - \\
- & - & - & - & - & - & 7.41 & 41.4 & - & - \\
- & - & - & - & - & - & 7.60 & 99.7 & - & - \\
- & - & - & - & - & - & 7.72 & 33.0 & - & - \\
- & - & - & - & - & - & 7.87 & 63.0 & - & - \\
- & - & - & - & - & - & 8.02 & 100.0 & - & - \\
- & - & - & - & - & - & 8.19 & 29.3 & - & - \\
- & - & - & - & - & - & 8.24 & 100.0 & - & - \\
\hline
\end{tabular}


Appendix B: Table of frozen bulk densities $(\rho)$ with depth from all deep boreholes at BCSA.

\begin{tabular}{|c|c|c|c|c|c|c|c|c|c|}
\hline \multicolumn{2}{|c|}{ BH01 } & \multicolumn{2}{|c|}{ ВН02 } & \multicolumn{2}{|c|}{ BH03 } & \multicolumn{2}{|c|}{ ВН04 } & \multicolumn{2}{|c|}{ BH05 } \\
\hline $\begin{array}{c}\text { Depth } \\
\text { (m) }\end{array}$ & $\begin{array}{c}\rho \\
\left(\mathrm{g} \mathrm{cm}^{-3}\right)\end{array}$ & $\begin{array}{c}\text { Depth } \\
\text { (m) }\end{array}$ & $\begin{array}{c}\rho \\
\left(\mathrm{g} \mathrm{cm}^{-3}\right)\end{array}$ & $\begin{array}{c}\text { Depth } \\
\text { (m) }\end{array}$ & $\begin{array}{c}\rho \\
\left(\mathrm{g} \mathrm{cm}^{-3}\right)\end{array}$ & $\begin{array}{c}\text { Depth } \\
\text { (m) }\end{array}$ & $\begin{array}{c}\rho \\
\left(\mathrm{g} \mathrm{cm}^{-3}\right)\end{array}$ & $\begin{array}{c}\text { Depth } \\
\text { (m) }\end{array}$ & $\begin{array}{c}\rho \\
\left(\mathrm{g} \mathrm{cm}^{-3}\right)\end{array}$ \\
\hline 0.45 & 0.88 & 1.08 & 0.62 & 1.72 & 1.57 & 1.04 & 1.56 & 1.49 & 1.36 \\
\hline 0.64 & 0.96 & 1.21 & 1.02 & 1.94 & 1.66 & 1.21 & 1.72 & 1.71 & 1.60 \\
\hline 0.81 & 0.85 & 1.31 & 1.45 & 2.10 & 1.61 & 1.36 & 1.57 & 1.88 & 1.46 \\
\hline 1.20 & 1.85 & 1.55 & 1.60 & 2.27 & 1.49 & 1.57 & 1.54 & 2.08 & 1.45 \\
\hline 1.36 & 2.12 & 1.70 & 1.76 & 2.46 & 1.57 & 1.81 & 1.60 & 2.34 & 1.58 \\
\hline 1.52 & 1.71 & 1.86 & 1.53 & 2.62 & 1.52 & 1.98 & 1.83 & 2.53 & 1.63 \\
\hline 1.68 & 1.79 & 2.05 & 1.58 & 2.85 & 1.71 & 2.14 & 1.76 & 2.74 & 1.64 \\
\hline 1.82 & 1.69 & 2.27 & 1.71 & 3.08 & 1.85 & 2.31 & 1.63 & 2.91 & 1.71 \\
\hline 1.94 & 1.57 & 2.51 & 1.77 & 3.28 & 2.06 & 2.45 & 1.69 & 3.16 & 1.53 \\
\hline 2.07 & 1.82 & 2.76 & 1.84 & 3.43 & 1.78 & 2.62 & 1.37 & 3.40 & 1.50 \\
\hline 2.19 & 2.03 & 3.00 & 2.02 & 3.59 & 1.56 & 2.79 & 1.65 & 3.67 & 1.56 \\
\hline 2.49 & 2.19 & 3.20 & 2.29 & 3.81 & 1.59 & 2.95 & 1.66 & 3.84 & 1.71 \\
\hline 2.57 & 1.81 & 3.40 & 1.70 & 4.01 & 1.43 & 3.10 & 1.56 & 3.97 & 1.60 \\
\hline 2.75 & 1.88 & 3.66 & 1.80 & 4.19 & 1.39 & 3.24 & 1.70 & 4.13 & 1.61 \\
\hline 2.87 & 1.72 & 3.87 & 1.75 & 4.36 & 1.86 & 3.43 & 1.66 & 4.35 & 1.75 \\
\hline 3.03 & 1.70 & 4.04 & 1.62 & 4.50 & 2.12 & 3.65 & 1.77 & 4.53 & 1.72 \\
\hline 3.26 & 1.91 & 4.23 & 1.76 & 4.66 & 1.87 & 3.83 & 1.52 & 4.79 & 1.63 \\
\hline 3.58 & 1.66 & 4.47 & 1.96 & 4.82 & 1.82 & 3.98 & 1.65 & 5.03 & 1.78 \\
\hline 3.97 & 1.68 & 4.69 & 1.53 & 4.95 & 1.83 & 4.06 & 1.54 & 5.21 & 1.96 \\
\hline 4.25 & 1.56 & 4.87 & 1.58 & 5.09 & 1.15 & 4.14 & 1.43 & 5.30 & 1.40 \\
\hline 4.48 & 1.63 & 5.11 & 1.39 & 5.27 & 1.64 & 4.22 & 1.46 & 5.49 & 1.58 \\
\hline - & - & 5.39 & 1.72 & 5.46 & 1.67 & 4.39 & 1.51 & 5.73 & 1.70 \\
\hline - & - & 5.59 & 0.54 & 5.62 & 1.39 & 4.59 & 1.35 & 5.93 & 1.53 \\
\hline - & - & 5.71 & 1.20 & 5.80 & 1.82 & 4.86 & 1.31 & 6.18 & 1.65 \\
\hline- & - & 5.91 & 1.78 & 5.96 & 1.22 & 5.10 & 1.44 & 6.33 & 1.21 \\
\hline- & - & - & - & 6.17 & 1.78 & 5.32 & 1.36 & 6.54 & 1.47 \\
\hline - & - & - & - & 6.36 & 1.33 & 5.56 & 1.60 & 6.86 & 1.22 \\
\hline - & - & - & - & 6.54 & 1.55 & 5.80 & 1.89 & 7.17 & 0.82 \\
\hline - & - & - & - & 6.77 & 1.69 & 5.99 & 1.71 & - & - \\
\hline - & - & - & - & 6.97 & 1.76 & 6.13 & 1.75 & - & - \\
\hline- & - & - & - & - & - & 6.27 & 1.87 & - & - \\
\hline - & - & - & - & - & - & 6.46 & 1.54 & - & - \\
\hline - & - & - & - & - & - & 6.72 & 0.9 & - & - \\
\hline- & - & - & - & - & - & 6.96 & 1.40 & - & - \\
\hline- & - & - & - & - & - & 7.17 & 1.83 & - & - \\
\hline- & - & - & - & - & - & 7.33 & 1.12 & - & - \\
\hline- & - & - & - & - & - & 7.50 & 1.84 & - & - \\
\hline- & - & - & - & - & - & 7.65 & 0.9 & - & - \\
\hline- & - & - & - & - & - & 7.79 & 1.73 & - & - \\
\hline- & - & - & - & - & - & 7.94 & 1.14 & - & - \\
\hline
\end{tabular}




\begin{tabular}{|c|c|c|c|c|c|c|c|c|c|}
\hline \multicolumn{2}{|c|}{ BH01 } & \multicolumn{2}{|c|}{ BH02 } & \multicolumn{2}{|c|}{ BH03 } & \multicolumn{2}{|c|}{ BH04 } & \multicolumn{2}{|c|}{ BH05 } \\
\hline $\begin{array}{c}\text { Depth } \\
\text { (m) }\end{array}$ & $\begin{array}{c}\rho \\
\left(\mathrm{g} \mathrm{cm}^{-3}\right)\end{array}$ & $\begin{array}{c}\text { Depth } \\
\text { (m) }\end{array}$ & $\begin{array}{c}\rho \\
\left(\mathrm{g} \mathrm{cm}^{-3}\right)\end{array}$ & $\begin{array}{c}\text { Depth } \\
\text { (m) }\end{array}$ & $\begin{array}{c}\rho \\
\left(\mathrm{g} \mathrm{cm}^{-3}\right)\end{array}$ & $\begin{array}{c}\text { Depth } \\
\text { (m) }\end{array}$ & $\begin{array}{c}\rho \\
\left(\mathrm{g} \mathrm{cm}^{-3}\right)\end{array}$ & $\begin{array}{c}\text { Depth } \\
\text { (m) }\end{array}$ & $\begin{array}{c}\rho \\
\left(\mathrm{g} \mathrm{cm}^{-3}\right)\end{array}$ \\
\hline- & - & - & - & - & - & 8.10 & 1.27 & - & - \\
\hline- & - & - & - & - & - & 8.21 & 2.09 & - & - \\
\hline- & - & - & - & - & - & 8.32 & 0.9 & - & - \\
\hline
\end{tabular}


Appendix C: Results of $\delta^{18} \mathrm{O}$ determinations from ice in boreholes BH01-05 at BCSA.

$\mathrm{SN}=$ supernatant water, $\mathrm{P}=$ pressed pore water.

\begin{tabular}{|c|c|c|c|c|c|c|c|c|c|c|c|c|c|c|}
\hline \multicolumn{3}{|c|}{ BH01 } & \multicolumn{3}{|c|}{ BH02 } & \multicolumn{3}{|c|}{ BH03 } & \multicolumn{3}{|c|}{ BH04 (a+b) } & \multicolumn{3}{|c|}{ BH05 } \\
\hline $\begin{array}{c}\text { Depth } \\
\text { (m) }\end{array}$ & $\begin{array}{c}\delta^{18} \mathrm{O} \\
(\%,)\end{array}$ & $\begin{array}{c}\text { SN/ } \\
\text { P }\end{array}$ & $\begin{array}{c}\text { Depth } \\
\text { (m) }\end{array}$ & $\begin{array}{c}\delta^{18} \mathrm{O} \\
(\% \mathrm{o})\end{array}$ & $\begin{array}{c}\text { SN/ } \\
\text { P }\end{array}$ & $\begin{array}{c}\text { Depth } \\
\text { (m) }\end{array}$ & $\begin{array}{c}\delta^{18} \mathrm{O} \\
(\% \mathrm{o})\end{array}$ & $\mathbf{S N} / \mathrm{P}$ & $\begin{array}{c}\text { Depth } \\
\text { (m) }\end{array}$ & $\begin{array}{c}\delta^{18} \mathrm{O} \\
(\%,)\end{array}$ & $\begin{array}{c}\text { SN/ } \\
\text { P }\end{array}$ & $\begin{array}{c}\text { Depth } \\
\text { (m) }\end{array}$ & $\begin{array}{c}\delta^{18} \mathrm{O} \\
(\%,)\end{array}$ & $\begin{array}{c}\text { SN/ } \\
\text { P }\end{array}$ \\
\hline 0.45 & -22.70 & SN & 1.31 & -18.77 & $\begin{array}{c}\mathrm{SN} / \\
\mathrm{P}\end{array}$ & 1.72 & -16.84 & SN & 1.57 & -16.52 & SN & 1.55 & -16.73 & SN \\
\hline 0.64 & -18.72 & SN & 1.55 & -17.65 & $\mathrm{P}$ & 2.27 & -15.92 & SN & 1.81 & -16.16 & SN & 1.88 & -16.68 & SN \\
\hline 0.81 & -16.79 & SN & 1.86 & -16.57 & $\mathrm{P}$ & 2.62 & -15.85 & $\mathrm{SN}$ & 2.31 & -16.06 & SN & 2.08 & -16.51 & SN \\
\hline 1.2 & -16.32 & SN & 2.27 & -16.25 & $\mathrm{P}$ & 3.81 & -16.82 & SN & 2.79 & -16.67 & SN & 2.91 & -16.34 & SN \\
\hline 1.36 & -16.49 & SN & 2.76 & -16.38 & $\mathrm{P}$ & 4.01 & -16.75 & SN & 3.1 & -16.78 & SN & 3.16 & -16.69 & SN \\
\hline 1.52 & -18.04 & SN & 3.4 & -16.72 & $\mathrm{P}$ & 5.09 & -17.36 & SN & 3.83 & -16.62 & SN & 3.4 & -16.80 & SN \\
\hline 1.68 & -18.90 & SN & 3.87 & -16.97 & $\mathrm{P}$ & 5.8 & -16.87 & $\mathrm{SN}$ & 4.06 & -16.58 & SN & 3.67 & -16.62 & SN \\
\hline 1.82 & -18.60 & SN & 4.04 & -15.36 & SN & 5.96 & -18.19 & $\mathrm{SN}$ & 4.14 & -15.78 & SN & 3.89 & -16.37 & SN \\
\hline 1.94 & -18.32 & SN & 4.69 & -17.44 & $\mathrm{P}$ & 6.36 & -18.77 & SN & 4.22 & -16.84 & SN & 3.97 & -16.59 & SN \\
\hline 2.07 & -18.59 & SN & 5.11 & -17.60 & SN & - & - & & 4.39 & -16.62 & SN & 4.24 & -15.72 & SN \\
\hline 2.19 & -18.58 & SN & 5.59 & -16.91 & SN & - & - & & 4.59 & -16.64 & SN & 4.68 & -16.51 & SN \\
\hline 2.57 & -18.60 & $\mathrm{P}$ & 5.71 & -17.52 & SN & - & - & & 4.86 & -16.76 & SN & 4.9 & -15.11 & SN \\
\hline 4.48 & -18.72 & $\mathrm{P}$ & - & - & & - & - & & 5.1 & -17.85 & SN & 5.37 & -16.34 & SN \\
\hline- & - & & - & - & & - & - & & 6.72 & -17.45 & SN & 5.63 & -16.54 & SN \\
\hline- & - & & - & - & & - & - & & 7.33 & -17.45 & SN & 5.82 & -16.78 & SN \\
\hline- & - & & - & - & & - & - & & 7.65 & -17.34 & SN & 5.9 & -17.18 & SN \\
\hline- & - & & - & - & & - & - & & 7.94 & -18.38 & SN & 6.39 & -16.86 & SN \\
\hline- & - & & - & - & & - & - & & 8.01 & -17.76 & SN & 6.43 & -16.62 & SN \\
\hline- & - & & - & - & & - & - & & 8.24 & -17.07 & SN & 6.99 & -17.28 & SN \\
\hline- & - & & - & - & & - & - & & 8.32 & -17.99 & SN & 7.17 & -17.51 & SN \\
\hline- & - & & - & - & & - & - & & - & - & & 7.3 & -16.70 & SN \\
\hline
\end{tabular}


Appendix D: Results of $\delta^{2} \mathrm{H}$ determinations from ice in boreholes BH01-05 at BCSA.

$\mathrm{SN}=$ supernatant water, $\mathrm{P}=$ pressed pore water.

\begin{tabular}{|c|c|c|c|c|c|c|c|c|c|c|c|c|c|c|}
\hline \multicolumn{3}{|c|}{ BH01 } & \multicolumn{3}{|c|}{ BH02 } & \multicolumn{3}{|c|}{ BH03 } & \multicolumn{3}{|c|}{ BH04 (a+b) } & \multicolumn{3}{|c|}{ BH05 } \\
\hline $\begin{array}{c}\text { Depth } \\
\text { (m) }\end{array}$ & $\begin{array}{l}\delta^{2} \mathbf{H} \\
(\%)\end{array}$ & $\begin{array}{c}\text { SN/ } \\
\text { P }\end{array}$ & $\begin{array}{c}\text { Depth } \\
\text { (m) }\end{array}$ & $\begin{array}{l}\delta^{2} \mathbf{H} \\
(\%)\end{array}$ & $\begin{array}{c}\text { SN/ } \\
\text { P }\end{array}$ & $\begin{array}{c}\text { Depth } \\
\text { (m) }\end{array}$ & $\begin{array}{l}\delta^{2} H \\
(\%)\end{array}$ & $\mathbf{S N} / \mathrm{P}$ & $\begin{array}{c}\text { Depth } \\
\text { (m) }\end{array}$ & $\begin{array}{l}\delta^{2} \mathbf{H} \\
(\%)\end{array}$ & $\begin{array}{c}\text { SN/ } \\
\text { P }\end{array}$ & $\begin{array}{c}\text { Depth } \\
\text { (m) }\end{array}$ & $\begin{array}{l}\delta^{2} \mathbf{H} \\
(\%)\end{array}$ & $\begin{array}{c}\text { SN/ } \\
\text { P }\end{array}$ \\
\hline 0.45 & -174.2 & SN & 1.31 & -155.5 & $\begin{array}{c}\mathrm{SN} / \\
\mathrm{P}\end{array}$ & 1.72 & -150.0 & SN & 1.57 & -149.4 & SN & 1.55 & -149.4 & SN \\
\hline 0.64 & -148.2 & SN & 1.55 & -149.2 & $\mathrm{P}$ & 2.27 & -143.9 & SN & 1.81 & -152.0 & SN & 1.88 & -152.0 & SN \\
\hline 0.81 & -143.5 & SN & 1.86 & -143.7 & $\mathrm{P}$ & 2.62 & -143.2 & $\mathrm{SN}$ & 2.31 & -146.7 & SN & 2.08 & -146.7 & SN \\
\hline 1.2 & -143.9 & SN & 2.27 & -140.8 & $\mathrm{P}$ & 3.81 & -147.7 & SN & 2.79 & -145.5 & SN & 2.91 & -145.5 & SN \\
\hline 1.36 & -145.8 & SN & 2.76 & -144.2 & $\mathrm{P}$ & 4.01 & -146.7 & SN & 3.1 & -147.6 & SN & 3.16 & -147.6 & SN \\
\hline 1.52 & -154.3 & SN & 3.4 & -145.4 & $\mathrm{P}$ & 5.09 & -149.1 & SN & 3.83 & -148.7 & SN & 3.4 & -148.7 & SN \\
\hline 1.68 & -157.6 & SN & 3.87 & -146.4 & $\mathrm{P}$ & 5.8 & -149.5 & $\mathrm{SN}$ & 4.06 & -147.4 & SN & 3.67 & -147.4 & SN \\
\hline 1.82 & -155.6 & SN & 4.04 & -145.1 & SN & 5.96 & -156.6 & $\mathrm{SN}$ & 4.14 & -145.8 & SN & 3.89 & -145.8 & SN \\
\hline 1.94 & -154.4 & SN & 4.69 & -150.2 & $\mathrm{P}$ & 6.36 & -159.2 & SN & 4.22 & -150.0 & SN & 3.97 & -150.0 & SN \\
\hline 2.07 & -154.7 & SN & 5.11 & -150.3 & SN & - & - & & 4.39 & -145.5 & SN & 4.24 & -145.5 & SN \\
\hline 2.19 & -154.9 & SN & 5.59 & -147.0 & SN & - & - & & 4.59 & -150.8 & SN & 4.68 & -150.8 & SN \\
\hline 2.57 & -153.2 & $\mathrm{P}$ & 5.71 & -149.0 & SN & - & - & & 4.86 & -146.0 & SN & 4.9 & -146.0 & SN \\
\hline 4.48 & -154.8 & $\mathrm{P}$ & - & - & & - & - & & 5.1 & -148.6 & SN & 5.37 & -148.6 & SN \\
\hline- & - & & - & - & & - & - & & 6.72 & -148.1 & SN & 5.63 & -148.1 & SN \\
\hline- & - & & - & - & & - & - & & 7.33 & -151.1 & SN & 5.82 & -151.1 & SN \\
\hline- & - & & - & - & & - & - & & 7.65 & -152.7 & SN & 5.9 & -152.7 & SN \\
\hline- & - & & - & - & & - & - & & 7.94 & -152.8 & SN & 6.39 & -152.8 & SN \\
\hline- & - & & - & - & & - & - & & 8.01 & -148.3 & SN & 6.43 & -148.3 & SN \\
\hline- & - & & - & - & & - & - & & 8.24 & -154.5 & SN & 6.99 & -154.5 & SN \\
\hline- & - & & - & - & & - & - & & 8.32 & -158.1 & SN & 7.17 & -158.1 & SN \\
\hline- & - & & - & - & & - & - & & - & - & & 7.3 & -150.8 & SN \\
\hline
\end{tabular}


Appendix E: Plot of $\delta^{18} \mathrm{O}$ values for all boreholes with depth at BCSA.

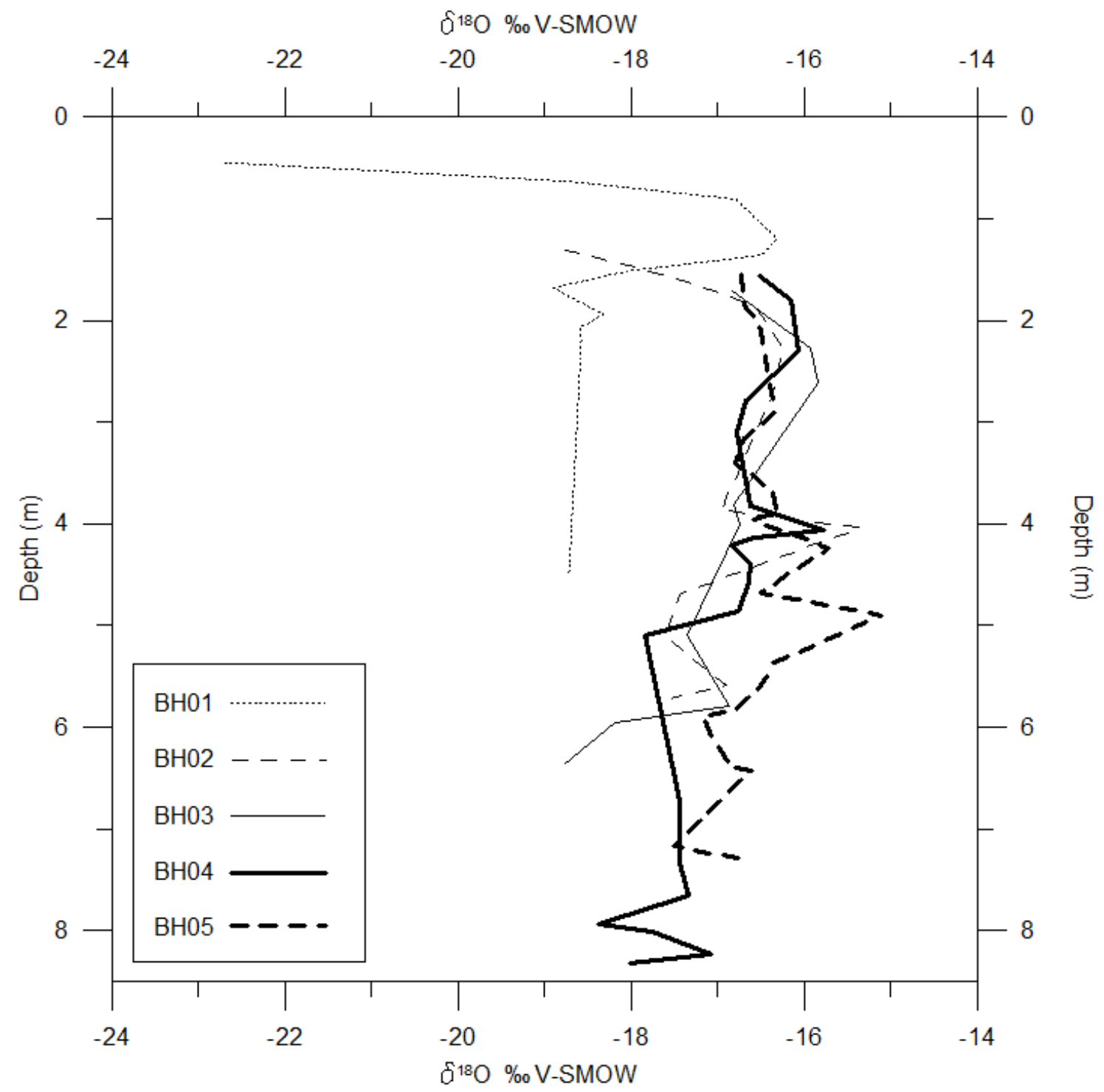


Appendix F: Results of stable isotope sampling of local water sources from summer 2012.

\begin{tabular}{|c|c|c|}
\hline Location & $\boldsymbol{\delta}^{\mathbf{1 8}} \mathbf{O}$ (\%o V-SMOW) & $\boldsymbol{\delta}^{\mathbf{2}} \mathbf{H}$ \%o (V-SMOW) \\
\hline Boundary Creek & -12.13 & -127.25 \\
BCSA pond & -15.61 & -142.82 \\
Local rain water & -14.8 & -129.54 \\
Yellowknife River & -14.49 & -138.11 \\
\hline
\end{tabular}


Appendix G: Geochemistry results of $\mathrm{Ca}^{2+}, \mathrm{Cl}^{-}$and $\mathrm{Mg}^{2+}$ with depth at all BCSA boreholes.

\begin{tabular}{|c|c|c|c|c|c|c|c|}
\hline Borehole & $\begin{array}{l}\text { Depth } \\
\text { (m) }\end{array}$ & $\mathrm{Ca}^{2+}(\mathrm{mg})$ & $\begin{array}{c}\mathrm{Ca}^{2+} \\
(\mathrm{mEq} / \mathrm{L})\end{array}$ & $\mathrm{Cl}^{-}(\mathrm{mg})$ & $\begin{array}{c}\mathrm{Cl}^{-} \\
(\mathrm{mEq} / \mathbf{L})\end{array}$ & $\mathrm{Mg}^{2+}(\mathrm{mg})$ & $\begin{array}{c}\mathbf{M g}^{2+} \\
(\mathbf{m E q} / \mathbf{L})\end{array}$ \\
\hline BH01 & 0.30 & 42.3 & 2.11 & 17 & 0.48 & 43.3 & 3.56 \\
\hline BH01 & 0.45 & 191 & 9.52 & 16 & 0.45 & 84.3 & 6.93 \\
\hline BH01 & 0.63 & 230 & 11.5 & 23 & 0.65 & 110 & 9.08 \\
\hline BH01 & 0.85 & 230 & 11.5 & 13.1 & 0.37 & 114 & 9.41 \\
\hline BH01 & 0.94 & 202 & 10.1 & 14.5 & 0.41 & 101 & 8.32 \\
\hline BH01 & 1.20 & 30.3 & 1.51 & 7.8 & 0.22 & 15.6 & 1.28 \\
\hline BH01 & 1.60 & 43.5 & 2.17 & 10.3 & 0.29 & 20.8 & 1.71 \\
\hline BH01 & 2.01 & 44.1 & 2.2 & 7.44 & 0.21 & 20.6 & 1.69 \\
\hline BH01 & 2.28 & 39.1 & 1.95 & 9.93 & 0.28 & 19.1 & 1.57 \\
\hline BH01 & 2.66 & 60.3 & 3.01 & 8.15 & 0.23 & 24.4 & 2.01 \\
\hline BH01 & 2.95 & 142 & 7.09 & 9.93 & 0.28 & 51.8 & 4.26 \\
\hline ВH01 & 3.12 & 157 & 7.83 & 10.3 & 0.29 & 52.8 & 4.34 \\
\hline BH01 & 3.40 & 77.4 & 3.86 & 10.3 & 0.29 & 28 & 2.3 \\
\hline BH01 & 3.77 & 57.3 & 2.86 & 11.3 & 0.32 & 21 & 1.73 \\
\hline ВH01 & 4.34 & 48.3 & 2.41 & 10.6 & 0.3 & 17.4 & 1.43 \\
\hline ВH01 & 4.61 & 44.3 & 2.21 & 12.1 & 0.34 & 16.4 & 1.35 \\
\hline ВH01 & 4.67 & 47.3 & 2.36 & 16.3 & 0.46 & 18.4 & 1.51 \\
\hline BH02 & 0.21 & 114 & 5.7 & 25.5 & 0.72 & 43.4 & 3.57 \\
\hline ВH02 & 0.44 & 100 & 5.01 & 22.7 & 0.64 & 49.4 & 4.06 \\
\hline ВH02 & 0.62 & 313 & 15.6 & 23.4 & 0.66 & 187 & 15.4 \\
\hline ВH02 & 0.85 & 387 & 19.3 & 19.5 & 0.55 & 243 & 20 \\
\hline ВH02 & 0.97 & 216 & 10.8 & 8.51 & 0.24 & 143 & 11.8 \\
\hline ВH02 & 1.16 & 281 & 14 & 7.8 & 0.22 & 175 & 14.4 \\
\hline ВH02 & 1.46 & 163 & 8.12 & 13.1 & 0.37 & 75.1 & 6.18 \\
\hline ВH02 & 1.63 & 138 & 6.88 & 12.4 & 0.35 & 60.6 & 4.98 \\
\hline ВH02 & 1.77 & 128 & 6.38 & 11.3 & 0.32 & 55.7 & 4.58 \\
\hline ВH02 & 1.95 & 110 & 5.48 & 13.8 & 0.39 & 47.2 & 3.88 \\
\hline ВH02 & 2.15 & 173 & 8.61 & 15.6 & 0.44 & 65.7 & 5.4 \\
\hline ВH02 & 2.39 & 154 & 7.69 & 15.2 & 0.43 & 53.3 & 4.38 \\
\hline ВH02 & 2.64 & 170 & 8.48 & 14.2 & 0.4 & 58.6 & 4.82 \\
\hline ВH02 & 2.89 & 167 & 8.34 & 18.1 & 0.51 & 60.6 & 4.98 \\
\hline ВH02 & 3.12 & 135 & 6.76 & 19.1 & 0.54 & 47.8 & 3.93 \\
\hline ВH02 & 3.29 & 202 & 10.1 & 17 & 0.48 & 68.5 & 5.63 \\
\hline ВH02 & 3.52 & 125 & 6.22 & 17 & 0.48 & 39.8 & 3.27 \\
\hline ВH02 & 3.97 & 129 & 6.44 & 18.1 & 0.51 & 39 & 3.21 \\
\hline ВH02 & 4.12 & 125 & 6.23 & 18.1 & 0.51 & 37.1 & 3.05 \\
\hline ВH02 & 4.34 & 92 & 4.59 & 15.6 & 0.44 & 25 & 2.06 \\
\hline ВH02 & 4.60 & 43.1 & 2.15 & 15.2 & 0.43 & 12.9 & 1.06 \\
\hline ВH02 & 4.80 & 57.7 & 2.88 & 20.6 & 0.58 & 17.1 & 1.41 \\
\hline ВH02 & 4.95 & 55.3 & 2.76 & 18.1 & 0.51 & 16.8 & 1.38 \\
\hline ВH02 & 5.26 & 51.3 & 2.56 & 22 & 0.62 & 16.9 & 1.39 \\
\hline ВH02 & 5.53 & 42.9 & 2.14 & 16.3 & 0.46 & 14.3 & 1.18 \\
\hline ВH02 & 5.64 & 91 & 4.54 & 27.7 & 0.78 & 33.8 & 2.78 \\
\hline BH02 & 5.80 & 46.3 & 2.31 & 36.5 & 1.03 & 16.4 & 1.35 \\
\hline
\end{tabular}




\begin{tabular}{|c|c|c|c|c|c|c|c|}
\hline Borehole & $\begin{array}{c}\text { Depth } \\
\text { (m) }\end{array}$ & $\mathrm{Ca}^{2+}(\mathrm{mg})$ & $\begin{array}{c}\mathbf{C a}^{2+} \\
(\mathbf{m E q} / \mathbf{L})\end{array}$ & Cl- (mg) & $\begin{array}{c}\mathrm{Cl}^{-} \\
(\mathrm{mEq} / \mathrm{L})\end{array}$ & $\mathrm{Mg}^{2+}(\mathrm{mg})$ & $\begin{array}{c}\mathbf{M g}^{2+} \\
(\mathbf{m E q} / \mathbf{L})\end{array}$ \\
\hline $\mathrm{BH} 03$ & 0.13 & 140 & 6.98 & 32.6 & 0.92 & 86.3 & 7.1 \\
\hline BH03 & 0.38 & 248 & 12.4 & 25.5 & 0.72 & 131 & 10.8 \\
\hline BH03 & 0.53 & 419 & 20.9 & 20.6 & 0.58 & 235 & 19.3 \\
\hline ВH03 & 0.69 & 197 & 9.83 & 9.57 & 0.27 & 125 & 10.3 \\
\hline BH03 & 0.84 & 206 & 10.3 & 7.8 & 0.22 & 136 & 11.2 \\
\hline BH03 & 1.00 & 250 & 12.5 & 8.51 & 0.24 & 163 & 13.4 \\
\hline BH03 & 1.26 & 218 & 10.9 & 8.15 & 0.23 & 143 & 11.8 \\
\hline ВH03 & 1.38 & 236 & 11.8 & 7.44 & 0.21 & 128 & 10.5 \\
\hline ВH03 & 1.51 & 204 & 10.2 & 9.93 & 0.28 & 102 & 8.35 \\
\hline ВH03 & 1.63 & 198 & 9.89 & 9.93 & 0.28 & 89.3 & 7.34 \\
\hline ВH03 & 1.83 & 81.8 & 4.08 & 13.5 & 0.38 & 35.5 & 2.92 \\
\hline ВH03 & 2.02 & 92.2 & 4.6 & 11.7 & 0.33 & 36.6 & 3.01 \\
\hline ВH03 & 2.19 & 168 & 8.38 & 16 & 0.45 & 63.8 & 5.25 \\
\hline ВH03 & 2.36 & 132 & 6.6 & 18.8 & 0.53 & 50.7 & 4.17 \\
\hline ВH03 & 2.54 & 119 & 5.94 & 16.7 & 0.47 & 44.6 & 3.67 \\
\hline ВH03 & 2.72 & 160 & 7.98 & 17.7 & 0.5 & 63.7 & 5.24 \\
\hline ВH03 & 2.98 & 122 & 6.08 & 17 & 0.48 & 44 & 3.62 \\
\hline ВH03 & 3.18 & 146 & 7.3 & 17.7 & 0.5 & 49.6 & 4.08 \\
\hline ВH03 & 3.37 & 168 & 8.36 & 31.6 & 0.89 & 53.1 & 4.37 \\
\hline ВH03 & 3.50 & 176 & 8.76 & 14.2 & 0.4 & 55.1 & 4.53 \\
\hline ВH03 & 3.69 & 124 & 6.2 & 14.5 & 0.41 & 42.7 & 3.51 \\
\hline ВH03 & 3.93 & 84.2 & 4.2 & 23.8 & 0.67 & 27.8 & 2.29 \\
\hline ВH03 & 4.09 & 120 & 6.01 & 15.6 & 0.44 & 39.2 & 3.22 \\
\hline ВH03 & 4.28 & 103 & 5.14 & 20.6 & 0.58 & 33.8 & 2.78 \\
\hline ВH03 & 4.44 & 109 & 5.43 & 15.2 & 0.43 & 30.4 & 2.5 \\
\hline ВH03 & 4.58 & 59.1 & 2.95 & 12.8 & 0.36 & 19.5 & 1.6 \\
\hline ВH03 & 4.74 & 42.1 & 2.1 & 14.2 & 0.4 & 13.5 & 1.11 \\
\hline ВH03 & 4.89 & 43.1 & 2.15 & 17.7 & 0.5 & 13.7 & 1.13 \\
\hline BH03 & 5.02 & 47.1 & 2.35 & 16.3 & 0.46 & 16.3 & 1.34 \\
\hline ВH03 & 5.18 & 45.3 & 2.26 & 18.1 & 0.51 & 15.4 & 1.27 \\
\hline ВH03 & 5.37 & 45.1 & 2.25 & 22.7 & 0.64 & 15.8 & 1.3 \\
\hline $\mathrm{BH} 03$ & 5.53 & 48.3 & 2.41 & 20.9 & 0.59 & 15.6 & 1.28 \\
\hline $\mathrm{BH} 03$ & 5.72 & 46.1 & 2.3 & 23.8 & 0.67 & 15.9 & 1.31 \\
\hline ВH03 & 5.88 & 42.1 & 2.1 & 24.5 & 0.69 & 15.9 & 1.31 \\
\hline $\mathrm{BH} 03$ & 6.05 & 40.1 & 2 & 30.8 & 0.87 & 14.6 & 1.2 \\
\hline $\mathrm{BH} 03$ & 6.30 & 41.1 & 2.05 & 25.5 & 0.72 & 14.1 & 1.16 \\
\hline $\mathrm{BH} 03$ & 6.43 & 44.7 & 2.23 & 24.1 & 0.68 & 15.7 & 1.29 \\
\hline $\mathrm{BH} 03$ & 6.65 & 86.4 & 4.31 & 22.7 & 0.64 & 34 & 2.8 \\
\hline BH03 & 6.88 & 40.5 & 2.02 & 20.2 & 0.57 & 18 & 1.48 \\
\hline BH04 & 0.13 & 161 & 8.02 & 37.2 & 1.05 & 68.2 & 5.61 \\
\hline BH04 & 0.28 & 261 & 13 & 36.2 & 1.02 & 85.7 & 7.05 \\
\hline BH04 & 0.57 & 216 & 10.8 & 16.3 & 0.46 & 87.8 & 7.22 \\
\hline BH04 & 0.71 & 112 & 5.6 & 7.44 & 0.21 & 63.1 & 5.19 \\
\hline BH04 & 0.81 & 135 & 6.72 & 9.22 & 0.26 & 79.2 & 6.51 \\
\hline BH04 & 0.95 & 67.7 & 3.38 & 4.25 & 0.12 & 42.1 & 3.46 \\
\hline BH04 & 1.12 & 130 & 6.51 & 8.15 & 0.23 & 74.7 & 6.14 \\
\hline BH04 & 1.30 & 192 & 9.59 & 5.67 & 0.16 & 90.5 & 7.44 \\
\hline BH04 & 1.45 & 86 & 4.29 & 11.3 & 0.32 & 37.2 & 3.06 \\
\hline BH04 & 1.68 & 74.5 & 3.72 & 9.22 & 0.26 & 32.7 & 2.69 \\
\hline
\end{tabular}




\begin{tabular}{|c|c|c|c|c|c|c|c|}
\hline Borehole & $\begin{array}{l}\text { Depth } \\
\text { (m) }\end{array}$ & $\mathrm{Ca}^{2+}(\mathrm{mg})$ & $\begin{array}{c}\mathrm{Ca}^{2+} \\
(\mathbf{m E q} / \mathbf{L})\end{array}$ & $\mathrm{Cl}^{-}$(mg) & $\begin{array}{c}\mathrm{Cl}^{-} \\
(\mathrm{mEq} / \mathbf{L})\end{array}$ & $\mathrm{Mg}^{2+}(\mathrm{mg})$ & $\begin{array}{c}\mathbf{M g}^{2+} \\
(\mathbf{m E q} / \mathbf{L})\end{array}$ \\
\hline BH04 & 1.92 & 83.2 & 4.15 & 9.22 & 0.26 & 35 & 2.88 \\
\hline BH04 & 2.04 & 84.4 & 4.21 & 10.6 & 0.3 & 34.8 & 2.86 \\
\hline BH04 & 2.24 & 61.7 & 3.08 & 11.3 & 0.32 & 25 & 2.06 \\
\hline BH04 & 2.37 & 92 & 4.59 & 9.57 & 0.27 & 35.1 & 2.89 \\
\hline BH04 & 2.53 & 66.7 & 3.33 & 9.57 & 0.27 & 25.7 & 2.11 \\
\hline BH04 & 2.7 & 180 & 8.97 & 16.7 & 0.47 & 62.5 & 5.14 \\
\hline BH04 & 2.87 & 176 & 8.77 & 14.2 & 0.4 & 59.8 & 4.92 \\
\hline BH04 & 3.02 & 214 & 10.7 & 16 & 0.45 & 69.7 & 5.73 \\
\hline BH04 & 3.18 & 134 & 6.71 & 13.1 & 0.37 & 45 & 3.7 \\
\hline BH04 & 3.32 & 114 & 5.68 & 14.5 & 0.41 & 37 & 3.04 \\
\hline BH04 & 3.55 & 179 & 8.92 & 12.8 & 0.36 & 56.5 & 4.65 \\
\hline BH04 & 3.75 & 158 & 7.86 & 28.7 & 0.81 & 49.4 & 4.06 \\
\hline BH04 & 3.91 & 131 & 6.52 & 16.3 & 0.46 & 44.6 & 3.67 \\
\hline BH04 & 4 & 164 & 8.18 & 17.7 & 0.5 & 48.6 & 4 \\
\hline BH04 & 4.06 & 152 & 7.6 & 18.4 & 0.52 & 49.2 & 4.05 \\
\hline BH04 & 4.11 & 115 & 5.75 & 19.1 & 0.54 & 33.7 & 2.77 \\
\hline BH04 & 4.32 & 115 & 5.72 & 14.2 & 0.4 & 34.9 & 2.87 \\
\hline BH04 & 4.46 & 110 & 5.5 & 21.6 & 0.61 & 30.4 & 2.5 \\
\hline BH04 & 4.72 & 93.6 & 4.67 & 17.7 & 0.5 & 26.8 & 2.2 \\
\hline BH04 & 4.99 & 62.5 & 3.12 & 14.5 & 0.41 & 17.8 & 1.46 \\
\hline BH04 & 5.21 & 113 & 5.64 & 15.6 & 0.44 & 27.6 & 2.27 \\
\hline ВH04 & 5.43 & 79.8 & 3.98 & 12.8 & 0.36 & 24.6 & 2.02 \\
\hline BH04 & 5.68 & 48.1 & 2.4 & 12.4 & 0.35 & 13.9 & 1.14 \\
\hline ВH04 & 5.93 & 38.3 & 1.91 & 13.5 & 0.38 & 10.6 & 0.87 \\
\hline BH04 & 6.05 & 25.9 & 1.29 & 14.9 & 0.42 & 8.03 & 0.66 \\
\hline BH04 & 6.21 & 40.1 & 2 & 13.5 & 0.38 & 10.9 & 0.9 \\
\hline BH04 & 6.33 & 27.3 & 1.36 & 12.8 & 0.36 & 8.27 & 0.68 \\
\hline BH04 & 6.61 & 22.2 & 1.11 & 10.6 & 0.3 & 6.69 & 0.55 \\
\hline BH04 & 6.83 & 27.9 & 1.39 & 16 & 0.45 & 8.63 & 0.71 \\
\hline ВH04 & 7.08 & 96.2 & 4.8 & 16.7 & 0.47 & 31.1 & 2.56 \\
\hline BH04 & 7.26 & 35.7 & 1.78 & 14.9 & 0.42 & 10.6 & 0.87 \\
\hline BH04 & 7.4 & 53.1 & 2.65 & 19.5 & 0.55 & 16.2 & 1.33 \\
\hline BH04 & 7.71 & 18.8 & 0.94 & 23.8 & 0.67 & 5.84 & 0.48 \\
\hline BH04 & 7.87 & 12.4 & 0.62 & 11 & 0.31 & 3.65 & 0.3 \\
\hline BH04 & 8.18 & 41.5 & 2.07 & 21.6 & 0.61 & 11.9 & 0.98 \\
\hline BH05 & 0.18 & 195 & 9.71 & 43.2 & 1.22 & 118 & 9.68 \\
\hline ВH05 & 0.23 & 69.7 & 3.48 & 13.5 & 0.38 & 40.2 & 3.31 \\
\hline BH05 & 0.38 & 59.5 & 2.97 & 8.15 & 0.23 & 35.8 & 2.94 \\
\hline BH05 & 0.53 & 92 & 4.59 & 15.2 & 0.43 & 52.3 & 4.3 \\
\hline BH05 & 0.73 & 77.4 & 3.86 & 9.57 & 0.27 & 37.3 & 3.07 \\
\hline BH05 & 1.03 & 156 & 7.76 & 7.44 & 0.21 & 59.8 & 4.92 \\
\hline ВH05 & 1.28 & 156 & 7.76 & 7.44 & 0.21 & 64.1 & 5.27 \\
\hline BH05 & 1.39 & 196 & 9.79 & 16 & 0.45 & 73.2 & 6.02 \\
\hline BH05 & 1.6 & 151 & 7.54 & 22.3 & 0.63 & 53.3 & 4.38 \\
\hline BH05 & 1.82 & 160 & 7.96 & 24.5 & 0.69 & 53.5 & 4.4 \\
\hline BH05 & 1.95 & 132 & 6.59 & 14.2 & 0.4 & 41.2 & 3.39 \\
\hline BH05 & 2.19 & 212 & 10.6 & 16.7 & 0.47 & 65.3 & 5.37 \\
\hline BH05 & 2.24 & 99.6 & 4.97 & 15.6 & 0.44 & 31.9 & 2.62 \\
\hline
\end{tabular}




\begin{tabular}{|c|c|c|c|c|c|c|c|}
\hline Borehole & $\begin{array}{c}\text { Depth } \\
\text { (m) }\end{array}$ & $\mathrm{Ca}^{2+}(\mathrm{mg})$ & $\begin{array}{c}\mathrm{Ca}^{2+} \\
(\mathrm{mEq} / \mathrm{L})\end{array}$ & $\mathrm{Cl}^{-}$(mg) & $\begin{array}{c}\mathrm{Cl}^{-} \\
(\mathrm{mEq} / \mathrm{L})\end{array}$ & $\mathrm{Mg}^{2+}(\mathrm{mg})$ & $\begin{array}{c}\mathbf{M g}^{2+} \\
(\mathrm{mEq} / \mathrm{L})\end{array}$ \\
\hline BH05 & 2.43 & 180 & 8.99 & 23.4 & 0.66 & 54.2 & 4.46 \\
\hline BH05 & 2.63 & 172 & 8.6 & 15.6 & 0.44 & 55.9 & 4.6 \\
\hline BH05 & 2.83 & 210 & 10.5 & 17.7 & 0.5 & 61.5 & 5.06 \\
\hline BH05 & 3.00 & 155 & 7.74 & 14.9 & 0.42 & 46 & 3.78 \\
\hline ВH05 & 3.05 & 110 & 5.48 & 15.2 & 0.43 & 33.6 & 2.76 \\
\hline ВH05 & 3.28 & 154 & 7.7 & 26.6 & 0.75 & 45.6 & 3.75 \\
\hline ВH05 & 3.54 & 75.6 & 3.77 & 26.6 & 0.75 & 22.9 & 1.88 \\
\hline BH05 & 3.78 & 63.5 & 3.17 & 17.7 & 0.5 & 19.2 & 1.58 \\
\hline BH05 & 3.92 & 117 & 5.82 & 16.7 & 0.47 & 32 & 2.63 \\
\hline BH05 & 4.03 & 92.4 & 4.61 & 14.9 & 0.42 & 27 & 2.22 \\
\hline BH05 & 4.27 & 115 & 5.74 & 13.5 & 0.38 & 32.1 & 2.64 \\
\hline BH05 & 4.44 & 180 & 8.99 & 19.5 & 0.55 & 36.8 & 3.03 \\
\hline ВH05 & 4.62 & 96.2 & 4.8 & 17.7 & 0.5 & 28.9 & 2.38 \\
\hline ВH05 & 4.97 & 85 & 4.24 & 18.1 & 0.51 & 20.1 & 1.65 \\
\hline ВH05 & 5.11 & 48.3 & 2.41 & 16.7 & 0.47 & 13.1 & 1.08 \\
\hline ВH05 & 5.41 & 39.7 & 1.98 & 21.6 & 0.61 & 10.9 & 0.9 \\
\hline BH05 & 5.58 & 46.7 & 2.33 & 24.5 & 0.69 & 12.8 & 1.05 \\
\hline ВH05 & 5.95 & 27.1 & 1.35 & 22.3 & 0.63 & 8.39 & 0.69 \\
\hline BH05 & 6.03 & 52.5 & 2.62 & 30.5 & 0.86 & 14.1 & 1.16 \\
\hline BH05 & 6.26 & 30.5 & 1.52 & 33.3 & 0.94 & 11.1 & 0.91 \\
\hline BH05 & 6.43 & 27.1 & 1.35 & 28.7 & 0.81 & 9.61 & 0.79 \\
\hline BH05 & 6.71 & 29.9 & 1.49 & 42.2 & 1.19 & 10.8 & 0.89 \\
\hline BH05 & 6.78 & 36.3 & 1.81 & 52.1 & 1.47 & 13.5 & 1.11 \\
\hline BH05 & 7.24 & 54.9 & 2.74 & 112 & 3.16 & 26.8 & 2.2 \\
\hline
\end{tabular}


Appendix $\mathrm{H}$ : Geochemistry results of $\mathrm{K}^{+}, \mathrm{Na}^{+}$and $\mathrm{SO}_{4}{ }^{-2}$ with depth at all BCSA boreholes.

\begin{tabular}{|c|c|c|c|c|c|c|c|}
\hline Borehole & $\begin{array}{l}\text { Depth } \\
\text { (m) }\end{array}$ & $\mathrm{K}^{+}(\mathbf{m g})$ & $\underset{(\mathbf{m E q} / \mathbf{L})}{\mathbf{K}^{+}}$ & $\mathrm{Na}^{+}(\mathrm{mg})$ & $\begin{array}{c}\mathrm{Na}^{+} \\
(\mathbf{m E q} / \mathbf{L})\end{array}$ & $\begin{array}{l}\mathrm{SO}_{4}{ }^{2-} \\
(\mathrm{mg})\end{array}$ & $\underset{(\mathrm{mEq} / \mathrm{L})}{\mathrm{SO}_{4}{ }^{2-}}$ \\
\hline BH01 & 0.30 & 30.9 & 0.79 & 12 & 0.5 & 24 & 1.49 \\
\hline BH01 & 0.45 & 18.8 & 0.48 & 9 & 0.41 & 93 & 5.81 \\
\hline BH01 & 0.64 & 22.7 & 0.58 & 17 & 0.75 & 117 & 7.29 \\
\hline BH01 & 0.85 & 6.26 & 0.16 & 22 & 0.96 & 154 & 9.62 \\
\hline BH01 & 0.94 & 6.65 & 0.17 & 34 & 1.46 & 134 & 8.33 \\
\hline ВН01 & 1.20 & 7.82 & 0.2 & 28 & 1.22 & 26 & 1.64 \\
\hline ВH01 & 1.60 & 9.38 & 0.24 & 29 & 1.24 & 22 & 1.37 \\
\hline ВH01 & 2.01 & 6.26 & 0.16 & 26 & 1.14 & 17 & 1.08 \\
\hline ВH01 & 2.28 & 7.04 & 0.18 & 33 & 1.43 & 21 & 1.32 \\
\hline ВH01 & 2.66 & 10.2 & 0.26 & 40 & 1.76 & 48 & 2.99 \\
\hline ВH01 & 2.94 & 12.9 & 0.33 & 54 & 2.34 & 164 & 10.2 \\
\hline ВH01 & 3.12 & 12.9 & 0.33 & 53 & 2.32 & 181 & 11.3 \\
\hline ВH01 & 3.40 & 10.9 & 0.28 & 59 & 2.58 & 84 & 5.25 \\
\hline ВH01 & 3.77 & 8.6 & 0.22 & 57 & 2.5 & 72 & 4.49 \\
\hline ВH01 & 4.34 & 7.04 & 0.18 & 62 & 2.71 & 68 & 4.23 \\
\hline ВH01 & 4.61 & 7.43 & 0.19 & 60 & 2.59 & 60 & 3.75 \\
\hline BH01 & 4.67 & 7.43 & 0.19 & 65 & 2.82 & 57 & 3.54 \\
\hline ВH02 & 0.21 & 12.1 & 0.31 & 34 & 1.46 & 145 & 9.04 \\
\hline ВH02 & 0.44 & 15.6 & 0.4 & 43 & 1.85 & 152 & 9.5 \\
\hline ВH02 & 0.62 & 23.1 & 0.59 & 69 & 3.02 & 463 & 28.9 \\
\hline ВH02 & 0.85 & 19.9 & 0.51 & 67 & 2.9 & 491 & 30.6 \\
\hline ВH02 & 0.97 & 24.6 & 0.63 & 55 & 2.38 & 340 & 21.2 \\
\hline ВH02 & 1.16 & 30.9 & 0.79 & 55 & 2.41 & 426 & 26.6 \\
\hline ВH02 & 1.46 & 21.1 & 0.54 & 34 & 1.46 & 170 & 10.6 \\
\hline ВH02 & 1.63 & 18.8 & 0.48 & 30 & 1.3 & 110 & 6.85 \\
\hline ВH02 & 1.77 & 15.6 & 0.4 & 26 & 1.15 & 113 & 7.02 \\
\hline ВH02 & 1.95 & 15.6 & 0.4 & 26 & 1.12 & 99 & 6.18 \\
\hline ВH02 & 2.15 & 15.6 & 0.4 & 29 & 1.27 & 186 & 11.6 \\
\hline ВH02 & 2.39 & 15.2 & 0.39 & 31 & 1.34 & 143 & 8.93 \\
\hline ВH02 & 2.64 & 15.6 & 0.4 & 33 & 1.42 & 162 & 10.1 \\
\hline $\mathrm{BH} 02$ & 2.89 & 14.9 & 0.38 & 36 & 1.57 & 204 & 12.7 \\
\hline $\mathrm{BH} 02$ & 3.12 & 14.9 & 0.38 & 42 & 1.82 & 140 & 8.76 \\
\hline ВH02 & 3.29 & 16.4 & 0.42 & 44 & 1.91 & 223 & 13.9 \\
\hline ВH02 & 3.52 & 14.9 & 0.38 & 48 & 2.07 & 95 & 5.93 \\
\hline $\mathrm{BH} 02$ & 3.97 & 15.2 & 0.39 & 52 & 2.26 & 108 & 6.71 \\
\hline $\mathrm{BH} 02$ & 4.12 & 13.3 & 0.34 & 51 & 2.22 & 115 & 7.2 \\
\hline ВH02 & 4.34 & 12.1 & 0.31 & 52 & 2.24 & 62 & 3.86 \\
\hline ВH02 & 4.60 & 7.82 & 0.2 & 40 & 1.75 & 28 & 1.76 \\
\hline ВH02 & 4.80 & 8.99 & 0.23 & 51 & 2.2 & 32 & 1.99 \\
\hline ВH02 & 4.95 & 9.78 & 0.25 & 50 & 2.17 & 33 & 2.06 \\
\hline ВH02 & 5.26 & 9.38 & 0.24 & 52 & 2.24 & 30 & 1.88 \\
\hline ВH02 & 5.53 & 8.99 & 0.23 & 46 & 1.99 & 28 & 1.72 \\
\hline ВH02 & 5.64 & 11.7 & 0.3 & 52 & 2.25 & 47 & 2.93 \\
\hline BH02 & 5.80 & 8.99 & 0.23 & 60 & 2.59 & 33 & 2.08 \\
\hline
\end{tabular}




\begin{tabular}{|c|c|c|c|c|c|c|c|}
\hline Borehole & $\begin{array}{l}\text { Depth } \\
\text { (m) }\end{array}$ & $\mathrm{K}^{+}(\mathrm{mg})$ & $\begin{array}{c}\mathbf{K}^{+} \\
(\mathbf{m E q} / \mathbf{L})\end{array}$ & $\mathrm{Na}^{+}(\mathrm{mg})$ & $\begin{array}{c}\mathrm{Na}^{+} \\
(\mathbf{m E q} / \mathbf{L})\end{array}$ & $\begin{array}{l}\mathrm{SO}_{4}{ }^{2-} \\
(\mathrm{mg})\end{array}$ & $\underset{(\mathrm{mEq} / \mathrm{L})}{\mathrm{SO}_{4}{ }^{2-}}$ \\
\hline BH03 & 0.13 & 12.5 & 0.32 & 23 & 0.98 & 94 & 5.87 \\
\hline BH03 & 0.38 & 12.9 & 0.33 & 70 & 3.04 & 401 & 25 \\
\hline ВH03 & 0.53 & 20.7 & 0.53 & 92 & 4 & 616 & 38.4 \\
\hline BH03 & 0.69 & 18.4 & 0.47 & 63 & 2.73 & 330 & 20.6 \\
\hline ВH03 & 0.84 & 21.1 & 0.54 & 59 & 2.57 & 354 & 22.1 \\
\hline ВH03 & 1.00 & 27 & 0.69 & 60 & 2.6 & 391 & 24.4 \\
\hline ВH03 & 1.26 & 23.5 & 0.6 & 49 & 2.14 & 348 & 21.7 \\
\hline ВH03 & 1.38 & 22.7 & 0.58 & 38 & 1.66 & 349 & 21.8 \\
\hline ВH03 & 1.51 & 21.1 & 0.54 & 35 & 1.53 & 276 & 17.2 \\
\hline $\mathrm{BH} 03$ & 1.63 & 21.9 & 0.56 & 33 & 1.43 & 252 & 15.7 \\
\hline $\mathrm{BH} 03$ & 1.83 & 15.2 & 0.39 & 26 & 1.14 & 73 & 4.54 \\
\hline $\mathrm{BH} 03$ & 2.02 & 14.1 & 0.36 & 26 & 1.11 & 77 & 4.8 \\
\hline ВH03 & 2.19 & 17.2 & 0.44 & 32 & 1.37 & 181 & 11.3 \\
\hline ВH03 & 2.36 & 14.1 & 0.36 & 28 & 1.22 & 152 & 9.5 \\
\hline ВH03 & 2.54 & 13.7 & 0.35 & 32 & 1.4 & 135 & 8.45 \\
\hline BH03 & 2.72 & 17.2 & 0.44 & 38 & 1.64 & 173 & 10.8 \\
\hline ВH03 & 2.98 & 11.3 & 0.29 & 32 & 1.4 & 149 & 9.28 \\
\hline ВH03 & 3.18 & 12.5 & 0.32 & 39 & 1.69 & 164 & 10.2 \\
\hline ВH03 & 3.37 & 13.3 & 0.34 & 43 & 1.88 & 186 & 11.6 \\
\hline $\mathrm{BH} 03$ & 3.50 & 14.1 & 0.36 & 44 & 1.92 & 188 & 11.7 \\
\hline ВH03 & 3.69 & 12.5 & 0.32 & 40 & 1.73 & 135 & 8.42 \\
\hline $\mathrm{BH} 03$ & 3.93 & 10.6 & 0.27 & 44 & 1.9 & 83 & 5.19 \\
\hline $\mathrm{BH} 03$ & 4.09 & 12.9 & 0.33 & 57 & 2.48 & 141 & 8.78 \\
\hline $\mathrm{BH} 03$ & 4.28 & 11.7 & 0.3 & 52 & 2.27 & 108 & 6.76 \\
\hline ВH03 & 4.44 & 12.1 & 0.31 & 52 & 2.27 & 100 & 6.25 \\
\hline ВH03 & 4.58 & 11.3 & 0.29 & 41 & 1.8 & 50 & 3.12 \\
\hline $\mathrm{BH} 03$ & 4.74 & 8.99 & 0.23 & 41 & 1.79 & 26 & 1.65 \\
\hline $\mathrm{BH} 03$ & 4.89 & 8.21 & 0.21 & 45 & 1.96 & 24 & 1.52 \\
\hline $\mathrm{BH} 03$ & 5.02 & 7.43 & 0.19 & 48 & 2.09 & 24 & 1.52 \\
\hline ВH03 & 5.18 & 9.38 & 0.24 & 48 & 2.1 & 23 & 1.46 \\
\hline $\mathrm{BH} 03$ & 5.37 & 7.82 & 0.2 & 52 & 2.26 & 25 & 1.57 \\
\hline $\mathrm{BH} 03$ & 5.53 & 8.6 & 0.22 & 50 & 2.16 & 23 & 1.43 \\
\hline $\mathrm{BH} 03$ & 5.72 & 8.99 & 0.23 & 56 & 2.42 & 25 & 1.53 \\
\hline ВH03 & 5.88 & 10.6 & 0.27 & 50 & 2.19 & 33 & 2.03 \\
\hline $\mathrm{BH} 03$ & 6.05 & 8.99 & 0.23 & 64 & 2.77 & 34 & 2.15 \\
\hline $\mathrm{BH} 03$ & 6.30 & 9.38 & 0.24 & 57 & 2.47 & 15 & 0.96 \\
\hline $\mathrm{BH} 03$ & 6.43 & 9.78 & 0.25 & 60 & 2.59 & 27 & 1.68 \\
\hline ВH03 & 6.65 & 10.9 & 0.28 & 54 & 2.34 & 39 & 2.42 \\
\hline BH03 & 6.88 & 8.99 & 0.23 & 26 & 1.14 & 23 & 1.44 \\
\hline BH04 & 0.13 & 10.2 & 0.26 & 47 & 2.04 & 199 & 12.4 \\
\hline ВH04 & 0.28 & 9.38 & 0.24 & 44 & 1.91 & 361 & 22.5 \\
\hline ВH04 & 0.57 & 12.5 & 0.32 & 42 & 1.82 & 239 & 14.9 \\
\hline BH04 & 0.71 & 14.9 & 0.38 & 38 & 1.66 & 131 & 8.18 \\
\hline BH04 & 0.81 & 18.8 & 0.48 & 43 & 1.85 & 164 & 10.2 \\
\hline BH04 & 0.95 & 15.6 & 0.4 & 30 & 1.29 & 107 & 6.7 \\
\hline BH04 & 1.12 & 21.1 & 0.54 & 40 & 1.72 & 199 & 12.4 \\
\hline BH04 & 1.30 & 20.3 & 0.52 & 34 & 1.5 & 263 & 16.4 \\
\hline BH04 & 1.45 & 16.8 & 0.43 & 32 & 1.41 & 75 & 4.68 \\
\hline BH04 & 1.68 & 16.4 & 0.42 & 31 & 1.34 & 72 & 4.5 \\
\hline
\end{tabular}




\begin{tabular}{|c|c|c|c|c|c|c|c|}
\hline Borehole & $\begin{array}{l}\text { Depth } \\
\text { (m) }\end{array}$ & $\mathbf{K}^{+}(\mathbf{m g})$ & $\begin{array}{c}\mathbf{K}^{+} \\
(\mathbf{m E q} / \mathbf{L})\end{array}$ & $\mathrm{Na}^{+}(\mathrm{mg})$ & $\begin{array}{c}\mathrm{Na}^{+} \\
(\mathbf{m E q} / \mathbf{L})\end{array}$ & $\begin{array}{l}\mathrm{SO}_{4}{ }^{2-} \\
(\mathrm{mg})\end{array}$ & $\underset{(\mathrm{mEq} / \mathrm{L})}{\mathrm{SO}_{4}{ }^{2-}}$ \\
\hline BH04 & 1.92 & 15.6 & 0.4 & 34 & 1.5 & 75 & 4.66 \\
\hline BH04 & 2.04 & 15.2 & 0.39 & 34 & 1.5 & 78 & 4.89 \\
\hline BH04 & 2.24 & 12.1 & 0.31 & 37 & 1.6 & 56 & 3.5 \\
\hline BH04 & 2.37 & 14.5 & 0.37 & 38 & 1.66 & 68 & 4.22 \\
\hline ВH04 & 2.53 & 12.1 & 0.31 & 34 & 1.48 & 62 & 3.84 \\
\hline BH04 & 2.70 & 16.4 & 0.42 & 46 & 2.02 & 204 & 12.7 \\
\hline ВH04 & 2.87 & 16 & 0.41 & 46 & 2.02 & 189 & 11.8 \\
\hline BH04 & 3.02 & 16.4 & 0.42 & 51 & 2.22 & 224 & 14 \\
\hline BH04 & 3.18 & 12.1 & 0.31 & 43 & 1.88 & 153 & 9.53 \\
\hline ВH04 & 3.32 & 11.3 & 0.29 & 40 & 1.72 & 130 & 8.08 \\
\hline ВH04 & 3.55 & 13.7 & 0.35 & 45 & 1.96 & 202 & 12.6 \\
\hline ВH04 & 3.75 & 12.9 & 0.33 & 51 & 2.21 & 191 & 11.9 \\
\hline ВH04 & 3.91 & 14.5 & 0.37 & 45 & 1.94 & 143 & 8.93 \\
\hline ВH04 & 4.00 & 12.5 & 0.32 & 50 & 2.17 & 186 & 11.6 \\
\hline ВH04 & 4.06 & 14.1 & 0.36 & 50 & 2.18 & 176 & 11 \\
\hline ВH04 & 4.11 & 12.5 & 0.32 & 46 & 1.98 & 122 & 7.64 \\
\hline ВH04 & 4.32 & 13.3 & 0.34 & 46 & 2 & 120 & 7.47 \\
\hline ВH04 & 4.46 & 10.9 & 0.28 & 50 & 2.16 & 112 & 7 \\
\hline BH04 & 4.72 & 10.2 & 0.26 & 48 & 2.09 & 95 & 5.93 \\
\hline ВH04 & 4.99 & 8.6 & 0.22 & 31 & 1.36 & 63 & 3.9 \\
\hline ВH04 & 5.21 & 10.9 & 0.28 & 50 & 2.18 & 101 & 6.28 \\
\hline BH04 & 5.43 & 10.9 & 0.28 & 47 & 2.04 & 92 & 5.75 \\
\hline ВH04 & 5.68 & 7.82 & 0.2 & 44 & 1.93 & 48 & 3 \\
\hline ВH04 & 5.93 & 6.65 & 0.17 & 44 & 1.9 & 28 & 1.74 \\
\hline ВH04 & 6.05 & 5.47 & 0.14 & 39 & 1.7 & 30 & 1.88 \\
\hline ВH04 & 6.21 & 6.26 & 0.16 & 44 & 1.9 & 28 & 1.75 \\
\hline ВH04 & 6.33 & 5.08 & 0.13 & 39 & 1.68 & 26 & 1.64 \\
\hline ВH04 & 6.61 & 5.08 & 0.13 & 36 & 1.56 & 20 & 1.25 \\
\hline ВH04 & 6.83 & 5.86 & 0.15 & 43 & 1.88 & 24 & 1.48 \\
\hline ВH04 & 7.08 & 10.9 & 0.28 & 63 & 2.72 & 121 & 7.53 \\
\hline ВH04 & 7.26 & 6.65 & 0.17 & 46 & 1.98 & 28 & 1.72 \\
\hline ВH04 & 7.40 & 8.6 & 0.22 & 56 & 2.45 & 60 & 3.76 \\
\hline ВH04 & 7.71 & 5.08 & 0.13 & 43 & 1.89 & 15 & 0.91 \\
\hline ВH04 & 7.87 & 4.69 & 0.12 & 25 & 1.1 & 7 & 0.42 \\
\hline BH04 & 8.18 & 7.04 & 0.18 & 58 & 2.54 & 25 & 1.58 \\
\hline BH05 & 0.18 & 172 & 4.41 & 16 & 0.68 & 36 & 2.24 \\
\hline BH05 & 0.23 & 16.4 & 0.42 & 18 & 0.78 & 30 & 1.84 \\
\hline BH05 & 0.38 & 13.3 & 0.34 & 20 & 0.88 & 31 & 1.96 \\
\hline ВH05 & 0.53 & 19.2 & 0.49 & 28 & 1.23 & 44 & 2.77 \\
\hline BH05 & 0.73 & 15.2 & 0.39 & 38 & 1.64 & 69 & 4.28 \\
\hline ВH05 & 1.03 & 15.6 & 0.4 & 37 & 1.59 & 136 & 8.49 \\
\hline ВH05 & 1.28 & 10.9 & 0.28 & 35 & 1.51 & 178 & 11.1 \\
\hline ВH05 & 1.39 & 13.3 & 0.34 & 44 & 1.91 & 199 & 12.4 \\
\hline ВH05 & 1.60 & 13.7 & 0.35 & 48 & 2.07 & 181 & 11.3 \\
\hline BH05 & 1.82 & 13.7 & 0.35 & 55 & 2.4 & 181 & 11.3 \\
\hline ВH05 & 1.95 & 12.1 & 0.31 & 46 & 2.01 & 146 & 9.1 \\
\hline BH05 & 2.19 & 16 & 0.41 & 55 & 2.4 & 218 & 13.6 \\
\hline BH05 & 2.24 & 10.9 & 0.28 & 41 & 1.8 & 109 & 6.77 \\
\hline
\end{tabular}




\begin{tabular}{|cc|cc|cc|cc|}
\hline Borehole & $\begin{array}{c}\text { Depth } \\
(\mathbf{m})\end{array}$ & $\mathbf{K}^{+}(\mathbf{m g})$ & $\begin{array}{c}\mathbf{K}^{+} \\
(\mathbf{m E q} / \mathbf{L})\end{array}$ & $\mathbf{N a}^{+} \mathbf{( m g )}$ & $\begin{array}{c}\mathbf{N a}^{+} \\
(\mathbf{m E q} / \mathbf{L})\end{array}$ & $\begin{array}{c}\mathbf{S O}_{\mathbf{4}}{ }^{2-} \\
(\mathbf{m g})\end{array}$ & $\begin{array}{c}\mathbf{S O}_{4}{ }^{2-} \\
(\mathbf{m E q} / \mathbf{L})\end{array}$ \\
\hline BH05 & 2.43 & 13.3 & 0.34 & 56 & 2.44 & 200 & 12.5 \\
BH05 & 2.63 & 14.5 & 0.37 & 47 & 2.05 & 208 & 13 \\
BH05 & 2.83 & 16 & 0.41 & 57 & 2.47 & 220 & 13.7 \\
BH05 & 3.00 & 14.1 & 0.36 & 54 & 2.36 & 159 & 9.94 \\
BH05 & 3.05 & 10.9 & 0.28 & 45 & 1.96 & 118 & 7.37 \\
BH05 & 3.28 & 12.1 & 0.31 & 60 & 2.59 & 183 & 11.4 \\
BH05 & 3.54 & 8.21 & 0.21 & 52 & 2.27 & 83 & 5.2 \\
BH05 & 3.78 & 8.99 & 0.23 & 47 & 2.05 & 67 & 4.18 \\
BH05 & 3.92 & 12.1 & 0.31 & 53 & 2.32 & 117 & 7.32 \\
BH05 & 4.03 & 10.9 & 0.28 & 48 & 2.1 & 95 & 5.93 \\
BH05 & 4.27 & 14.1 & 0.36 & 53 & 2.29 & 106 & 6.62 \\
BH05 & 4.44 & 13.7 & 0.35 & 65 & 2.81 & 143 & 8.95 \\
BH05 & 4.62 & 10.9 & 0.28 & 54 & 2.35 & 104 & 6.46 \\
BH05 & 4.97 & 10.2 & 0.26 & 55 & 2.39 & 65 & 4.05 \\
BH05 & 5.11 & 8.6 & 0.22 & 53 & 2.29 & 41 & 2.55 \\
BH05 & 5.41 & 8.21 & 0.21 & 52 & 2.26 & 24 & 1.48 \\
BH05 & 5.58 & 9.78 & 0.25 & 62 & 2.7 & 31 & 1.91 \\
BH05 & 5.95 & 6.26 & 0.16 & 51 & 2.2 & 15 & 0.95 \\
BH05 & 6.03 & 8.6 & 0.22 & 60 & 2.62 & 23 & 1.42 \\
BH05 & 6.26 & 7.43 & 0.19 & 56 & 2.45 & 20 & 1.26 \\
BH05 & 6.43 & 6.65 & 0.17 & 51 & 2.23 & 16 & 0.97 \\
BH05 & 6.71 & 7.04 & 0.18 & 66 & 2.88 & 25 & 1.56 \\
BH05 & 6.78 & 7.82 & 0.2 & 70 & 3.05 & 35 & 2.18 \\
BH05 & 7.24 & 10.9 & 0.28 & 137 & 5.98 & 69 & 4.29 \\
\hline
\end{tabular}


Appendix I.1: Plot of all ions with depth at BH01.

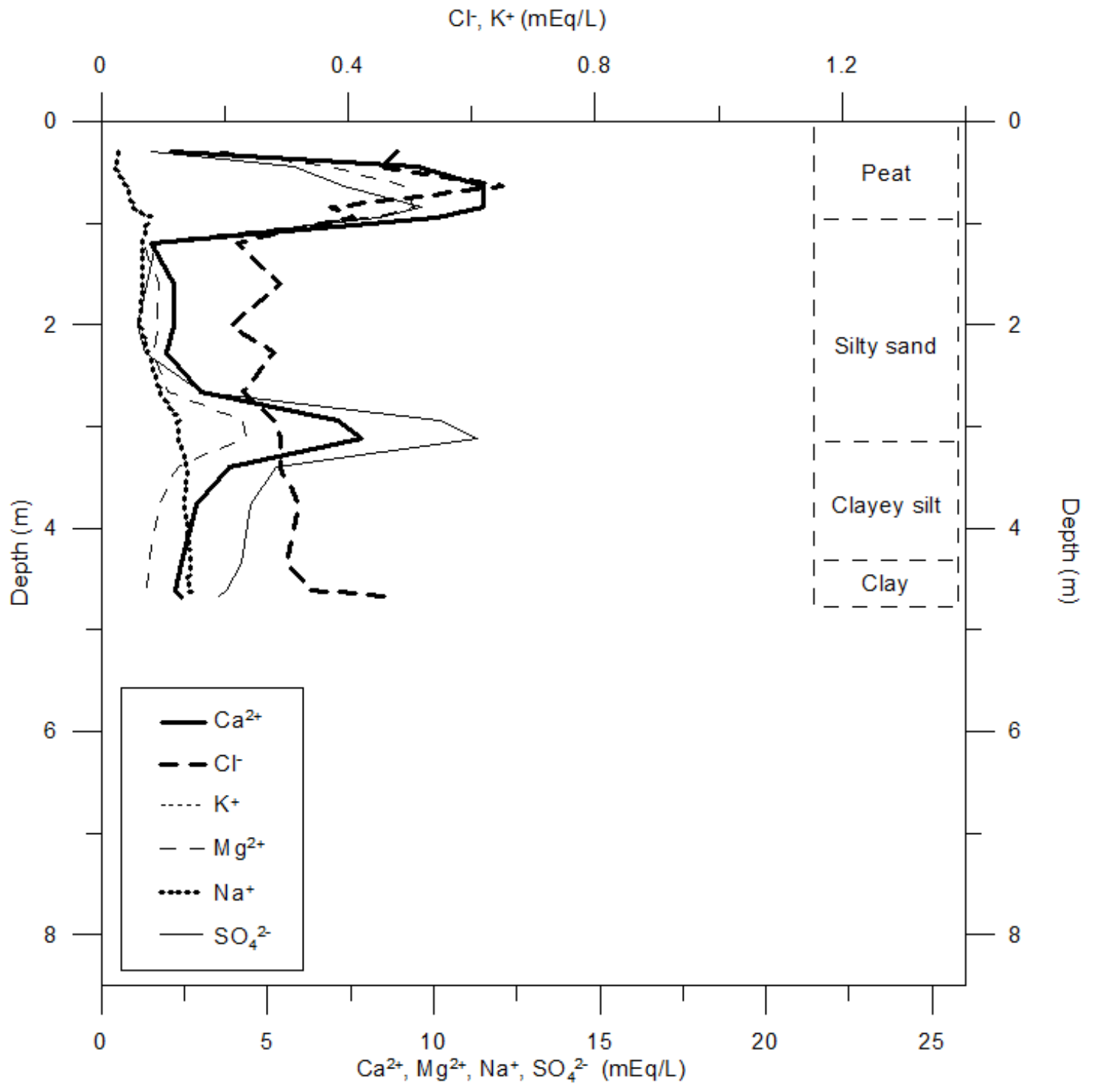


Appendix I.2: Plot of all ions with depth at BH02.

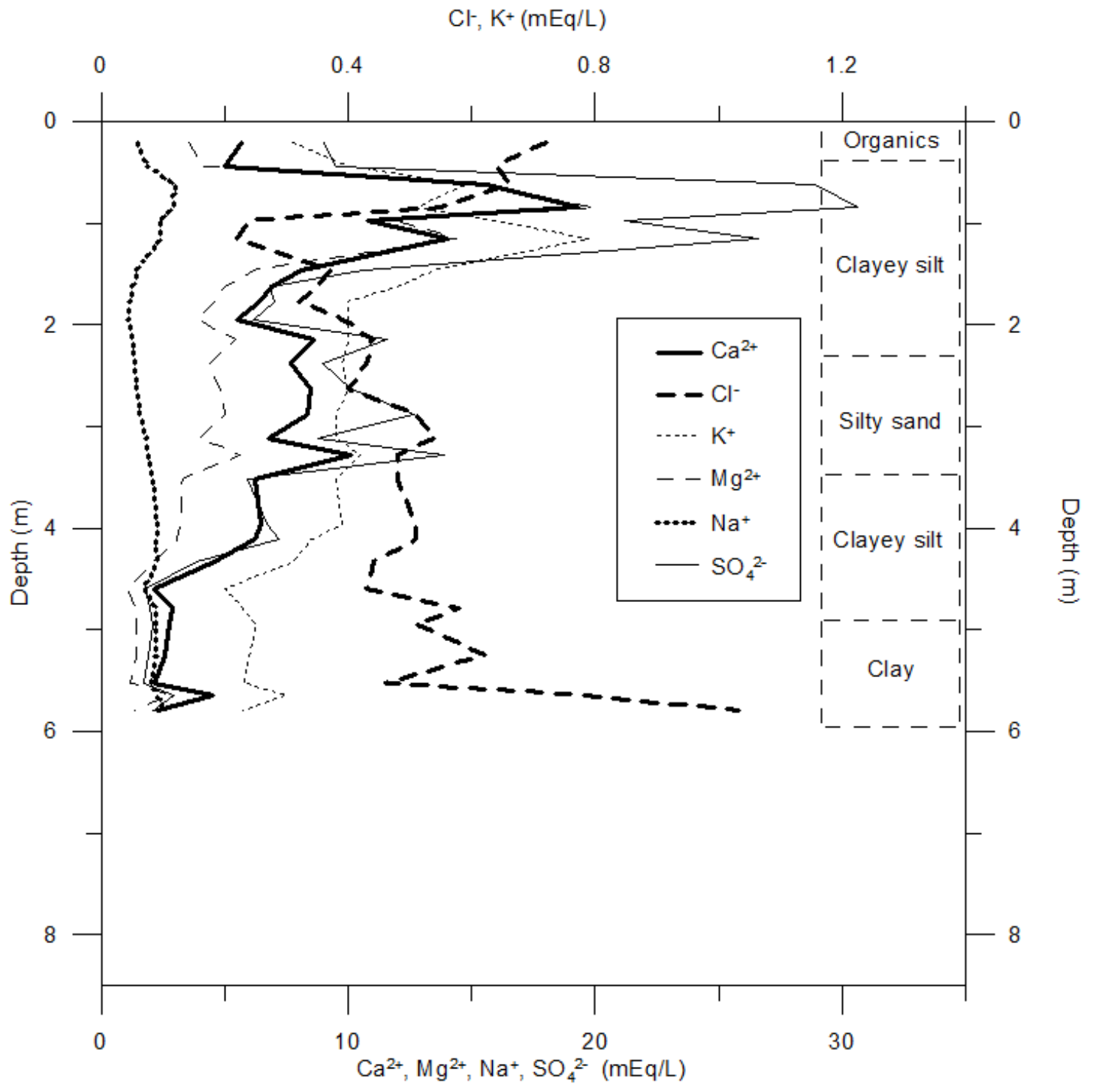


Appendix I.3: Plot of all ions with depth at BH03.

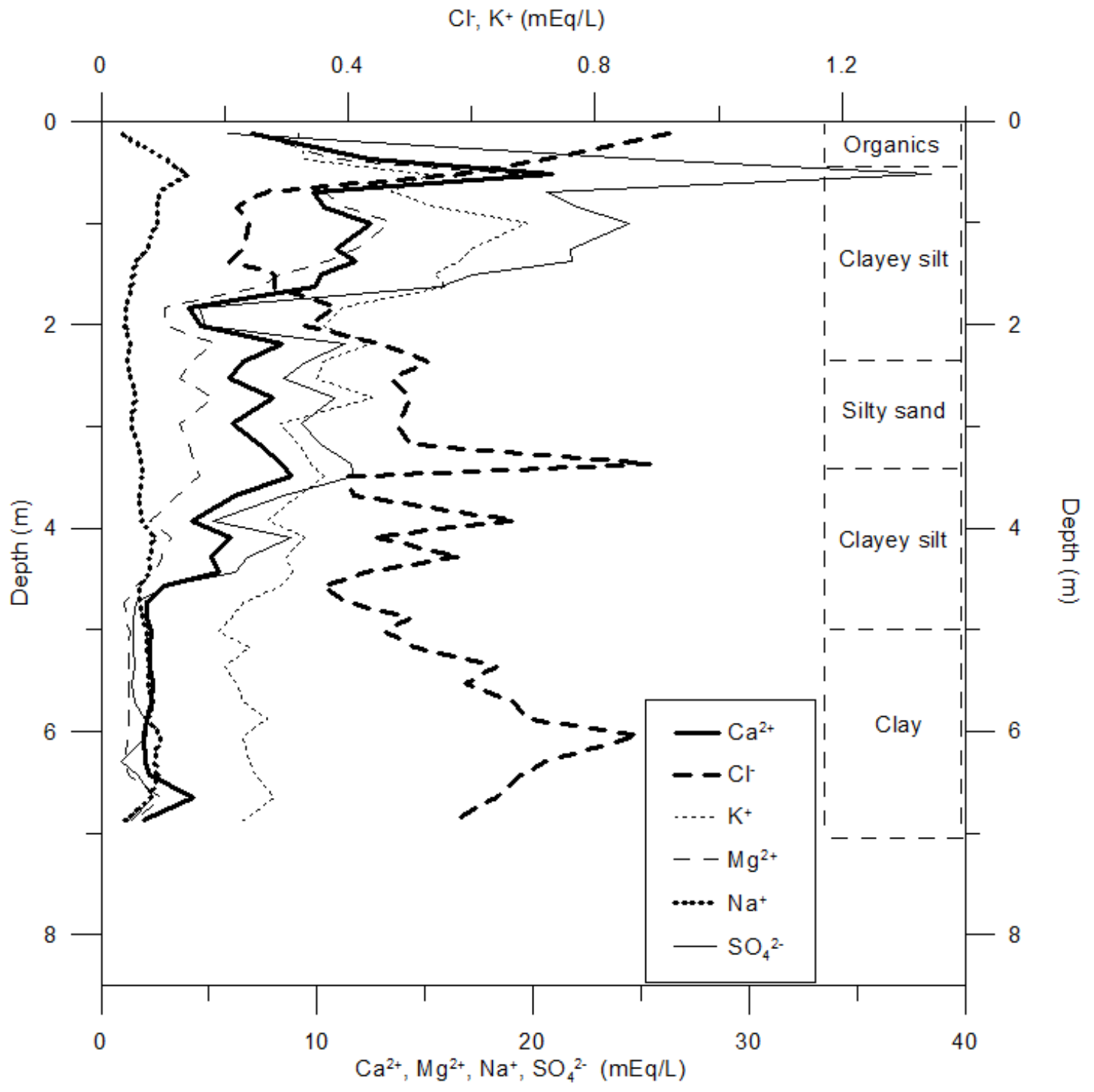


Appendix I.4: Plot of all ions with depth at BH04.

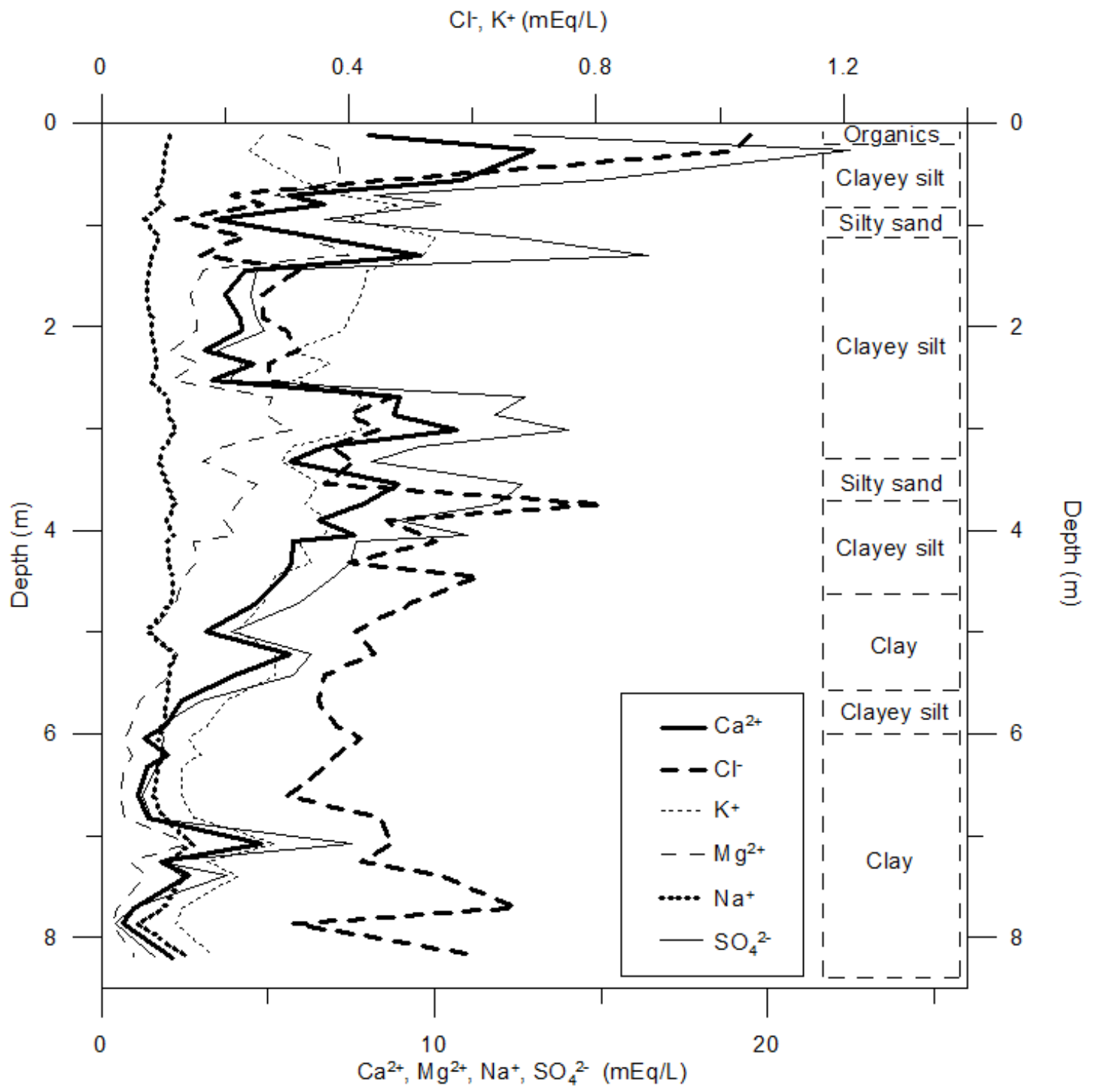


Appendix I.5: Plot of all ions with depth at BH05.

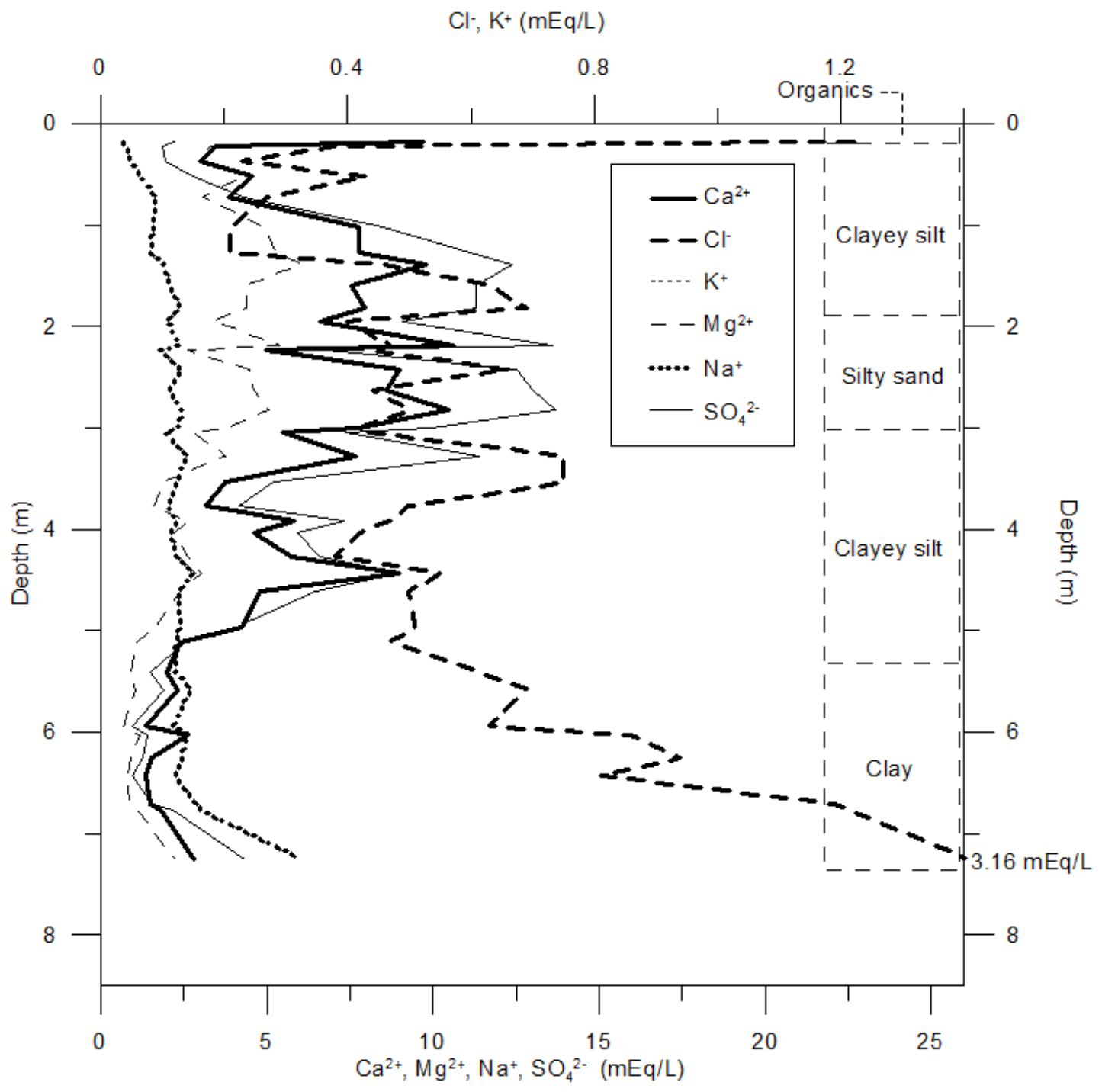


Appendix J: Plots of ion concentrations in samples recovered from $\mathrm{BH} 04$ indicating the strengths of relations between $\mathrm{Ca}^{2+}, \mathrm{Cl}^{-}, \mathrm{Mg}^{+}, \mathrm{K}^{+}, \mathrm{Na}^{+}$and $\mathrm{SO}_{4}{ }^{2-}$.
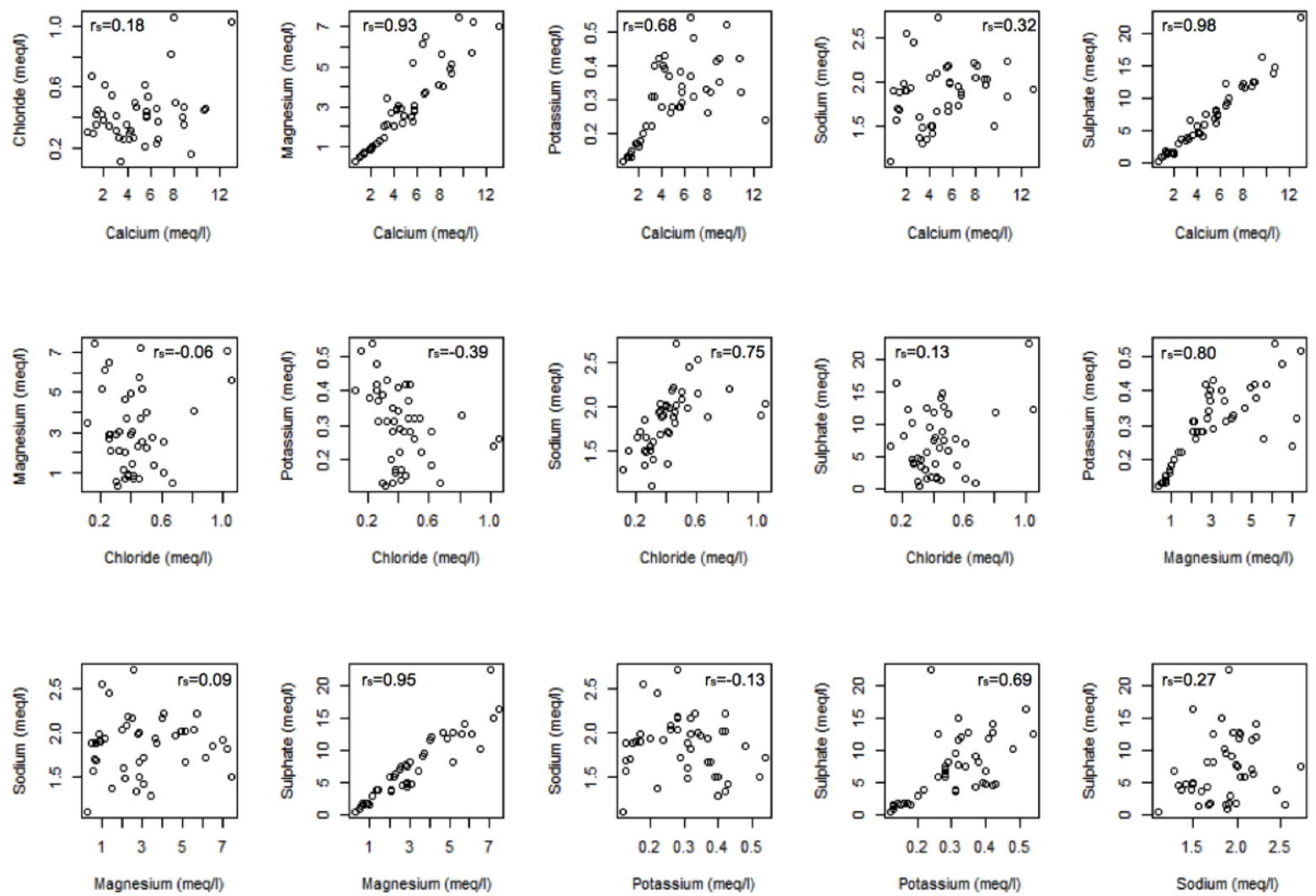